LA-14328-PR

Progress Report

Approved for public release;

distribution is unlimited.

Surface Water Data at

Los Alamos National Laboratory

2006 Water Year

- Los Alamos 
The most recent reports in this unclassified series are

LA-13706-PR, LA-13814-PR, LA-13905-PR, LA-14019-PR, LA-14131-PR, LA-14211-PR, and LA-14239-PR.

Edited by Mable Amador, IRM-CAS

Photocomposition by Julie Marquez, IRM-CAS

Los Alamos National Laboratory, an affirmative action/ equal opportunity employer, is operated by Los Alamos National Security, LLC, for the National Nuclear Security Administration of the U.S. Department of Energy under contract DE-AC52-06NA25396.

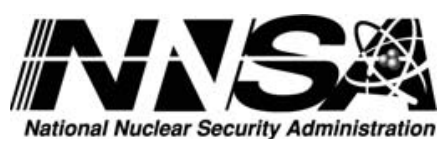

This report was prepared as an account of work sponsored by an agency of the U.S. Government. Neither Los Alamos National Security, LLC, the U.S. Government nor any agency thereof, nor any of their employees make any warranty, express or implied, or assume any legal liability or responsibility for the accuracy, completeness, or usefulness of any information, apparatus, product, or process disclosed, or represent that its use would not infringe privately owned rights. Reference herein to any specific commercial product, process, or service by trade name, trademark, manufacturer, or otherwise does not necessarily constitute or imply its endorsement, recommendation, or favoring by Los Alamos National Security, LLC, the U.S. Government, or any agency thereof. The views and opinions of authors expressed herein do not necessarily state or reflect those of Los Alamos National Security, LLC, the U.S. Government, or any agency thereof. Los Alamos National Laboratory strongly supports academic freedom and a researcher's right to publish; as an institution, however, the Laboratory does not endorse the viewpoint of a publication or guarantee its technical correctness. 
LA-14328-PR

Progress Report

Issued: August 2007

\section{Surface Water Data at}

Los Alamos National Laboratory 2006 Water Year
R.P. Romero
D. Ortiz
G. Kuyumjian 



\section{Contents}

Abbreviations, Acronyms, and Glossary ............................................................... ix

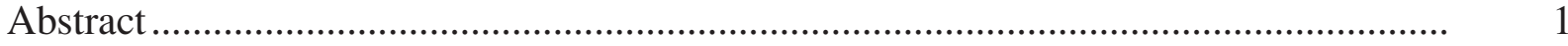

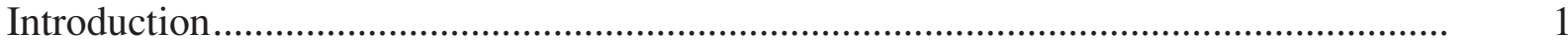

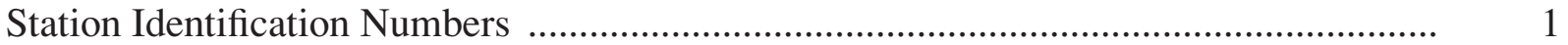

Data Collection and Computation ................................................................................ 2

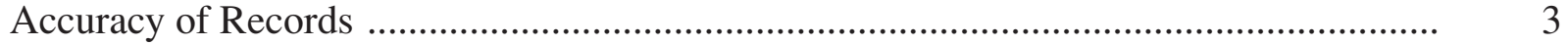

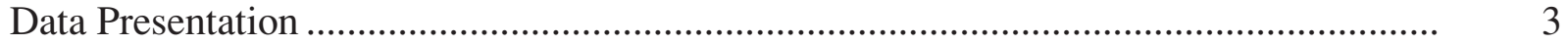

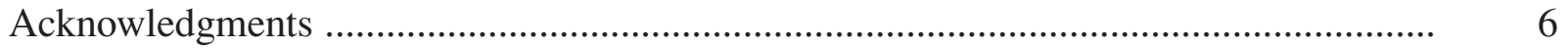

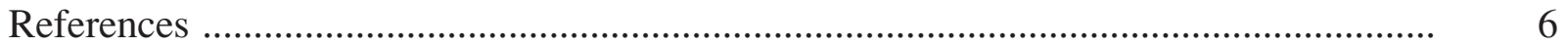

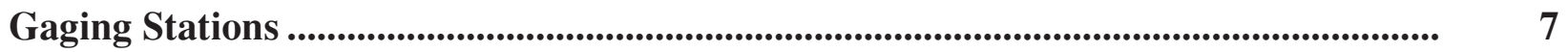

Gaging Stations at Los Alamos National Laboratory ............................................... 9

Summary of Discharges from Stream-Monitoring Stations at Los Alamos National

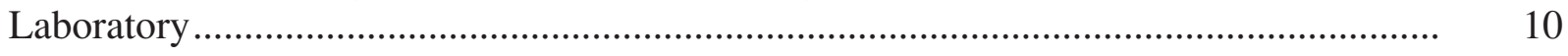

E026 Los Alamos Canyon below Ice Rink ................................................................ 11

E030 Los Alamos Canyon above DP Canyon................................................................. 14

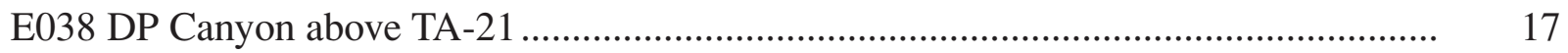

E040 DP Canyon above Los Alamos Canyon......................................................... 20

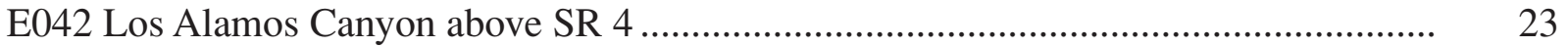

E050 Los Alamos Canyon below LA Weir ....................................................................... 26

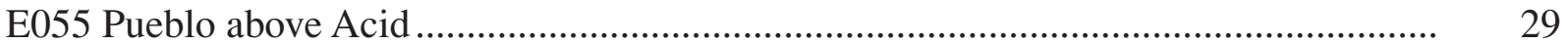

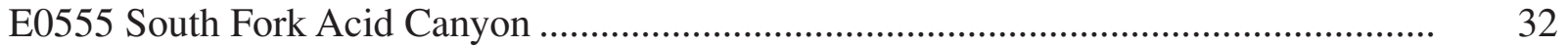

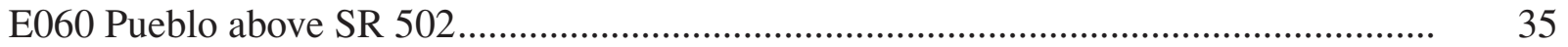

E121 Sandia Right Fork at Power Plant................................................................... 38

E1219 Sandia Canyon East of Power Plant .......................................................... 41

E1225 Sandia Canyon Tributary at Heavy Equipment ............................................. 44

E123 Sandia below Wetlands ................................................................................ 50

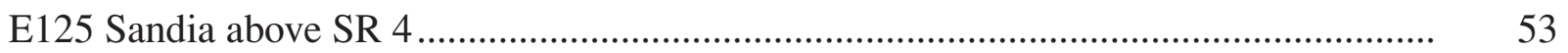

E200 Mortandad below Effluent Canyon................................................................. 56

E2015 Ten Site above Mortandad ...................................................................... 59

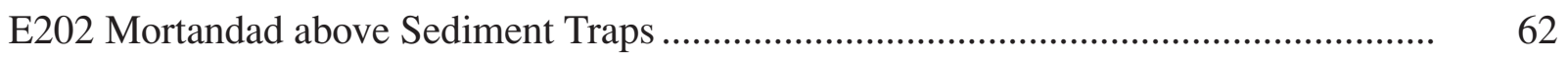

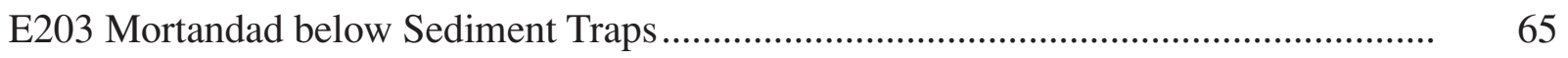

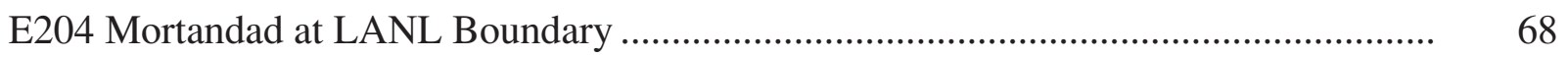

E218 Cañada del Buey near TA-46 ................................................................... 71 
E225 Cañada del Buey near MDA G.........................................................................

E230 Cañada del Buey above SR 4 .......................................................................... 77

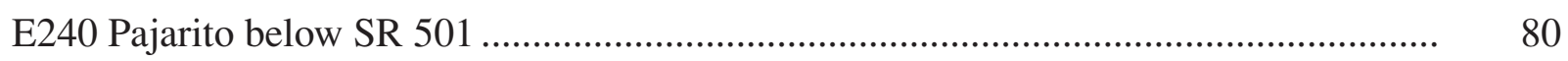

E241 Pajarito above Starmers ................................................................................... 83

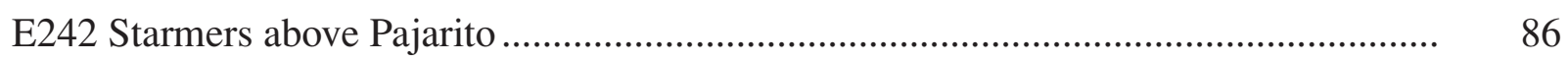

E2425 La Delfe above Pajarito ................................................................................... 89

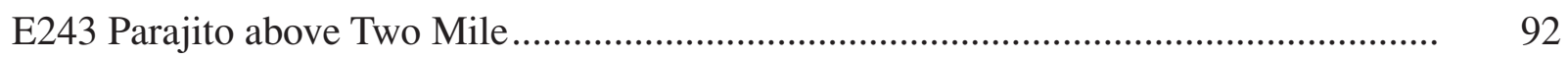

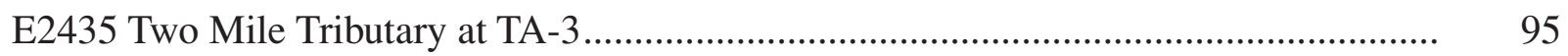

E244 Two Mile above Pajarito …………………………......................................... 98

E245 Pajarito above TA-18 …………………………............................................. 101

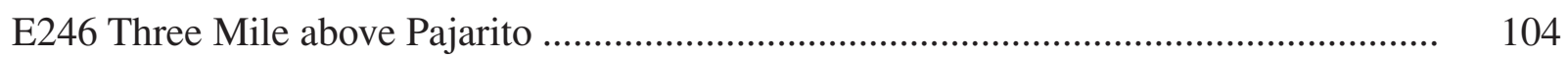

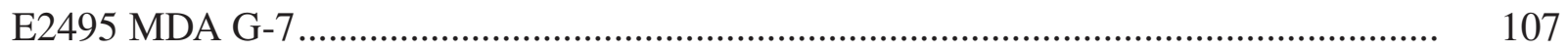

E250 Pajarito above SR 4 .................................................................................. 110

E252 Water above SR 501 ............................................................................. 113

E2528 S-Site Canyon above Water ............................................................................ 116

E253 Cañon de Valle above SR 501........................................................................... 119

E256 Cañon de Valle below MDA P......................................................................... 122

E262 Cañon de Valle above Water ............................................................................ 125

E2625 Water below MDA AB............................................................................ 128

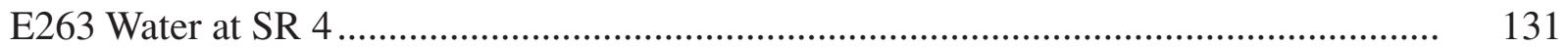

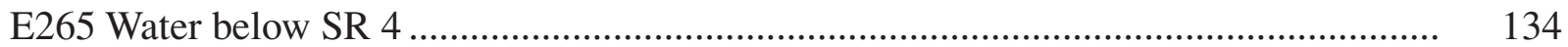

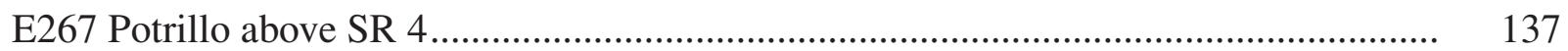

E275 Ancho below SR 4 ..................................................................................... 140

E350 Rio de los Frijoles at Bandelier ....................................................................... 143

Spring Stations .......................................................................................................................... 147

S001 SWSC Line Spring at TA-16 ....................................................................... 149

S002 Burn Ground Spring at TA-16 ...................................................................... 151

S003 Martin Spring at TA-16 ................................................................................ 153

Peak Flows ................................................................................................................................................ 155

E026 Los Alamos below Ice Rink................................................................................. 159

E030 Los Alamos above DP Canyon ........................................................................... 160

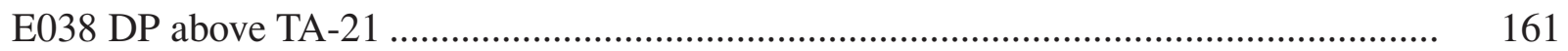

E040 DP above Los Alamos Canyon ............................................................................... 162 
E042 Los Alamos above SR 4.................................................................................. 163

E050 Los Alamos below LA Weir ........................................................................... 164

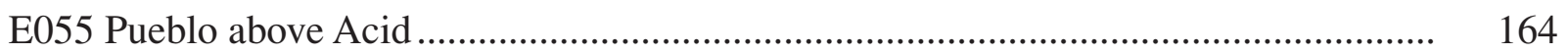

E0555 South Fork Acid Canyon .................................................................................. 165

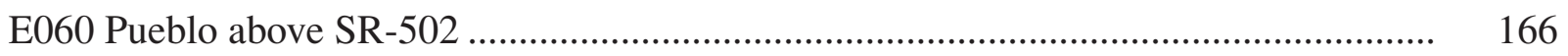

E121 Sandia Right Fork at Power Plant......................................................................... 167

E1219 Sandia Canyon East of Power Plant ................................................................... 167

E1225 Sandia Tributary at Heavy Equipment............................................................... 168

E123 Sandia below Wetlands ................................................................................. 169

E125 Sandia above SR 4 ............................................................................ 170

E200 Mortandad below Effluent Canyon........................................................................ 170

E2015 Ten Site above Mortandad ............................................................................... 171

E202 Mortandad above Sediment Traps ……………………………………………..... 171

E203 Mortandad below Sediment Traps ........................................................................ 172

E218 Cañada Del Buey near TA-46 ........................................................................ 172

E225 Cañada Del Buey near MDA G ......................................................................... 173

E230 Cañada Del Buey above SR 4 ......................................................................... 173

E240 Pajarito below SR 501 ................................................................................ 174

E241 Pajarito above Starmers ............................................................................. 174

E242 Starmers above Pajarito .................................................................................... 175

E2425 La Delfe above Pajarito ................................................................................. 175

E243 Pajarito above Twomile ............................................................................. 176

E2435 Two Mile Tributary at TA-3 ........................................................................ 176

E244 Two Mile above Pajarito................................................................................ 177

E245 Pajarito above TA-18 ………………………............................................... 178

E246 Three Mile above Pajarito ……………………............................................... 179

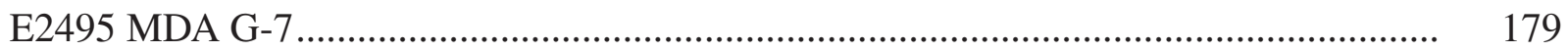

E250 Pajarito above SR 4 .................................................................................. 180

E252 Water above SR 501 ................................................................................ 181

E2528 S-Site Canyon above Water ........................................................................... 182

E253 Cañon de Valle above SR 501 ........................................................................... 182

E256 Cañon del Valle below MDA-P ......................................................................... 183

E262 Cañon De Valle above Water ............................................................................... 183

E2625 Water below MDA AB............................................................................... 184 


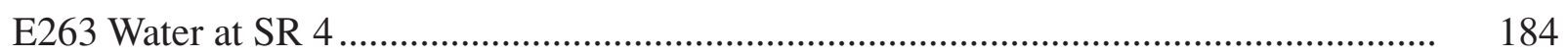

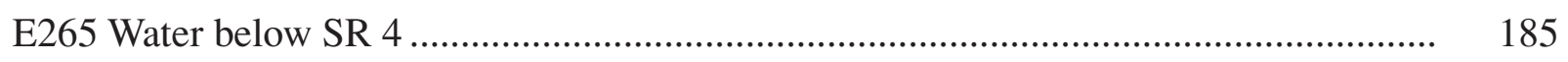

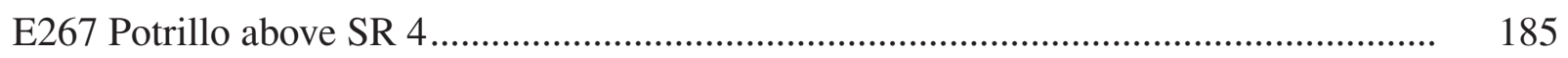

E275 Ancho below SR 4 ....................................................................................... 186

E350 Rio De Los Frijoles at Bandalier ................................................................... 186

Gaging Stations Omitted from this Publication ........................................................ 187

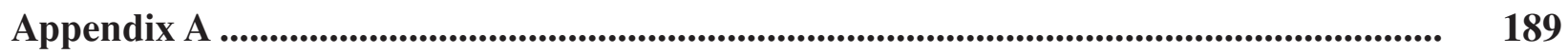

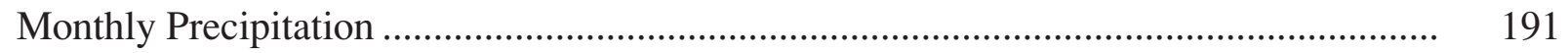




\section{Abbreviations, Acronyms, and Glossary}

Acre-foot (Ac-Ft, acre-ft) is the quantity of water required to cover 1 acre to a depth of 1 foot and is equivalent to 43,560 cubic feet, 325,851 gallons, or 1233.49 cubic meters.

Cfs-day is the volume of water represented by the flow of 1 cubic foot per second for 24 hours. It is equivalent to 86,400 cubic feet, 1.98347 acre-feet, 646,317 gallons, or 2,445 cubic meters.

Control designates a feature downstream from the gage that determines the stage-discharge relation at the gage. This feature may be a natural constriction of the channel, an artificial structure, or a uniform cross section over a long reach of the channel.

Control structure as used in this report is a structure on a stream or canal that is used to regulate the flow or stage of the stream or to prevent the intrusion of saltwater.

Cubic feet per second per square mile $\left[\left(\mathrm{ft}^{3} / \mathrm{s}\right) / \mathrm{mi}^{2}\right]$ is the average number of cubic feet of water flowing per second from each square mile of area drained, assuming that the runoff is distributed uniformly in time and area.

Cubic feet per second $\left(\mathrm{ft}^{3} / \mathrm{s}\right)$ is the rate of discharge representing a volume of 1 cubic foot passing a given point during 1 second and is equivalent to 7.48 gallons per second, 448.8 gallons per minute, or 0.02832 cubic meters per second.

Discharge is the volume of water (or more broadly, the volume of fluid including suspended sediment) that passes a given point within a given period of time.

Drainage area (DA) of a stream at a specified location is that area, measured in a horizontal plane and enclosed by a topographic divide, from which direct surface runoff from precipitation normally drains by gravity into the stream above the specified point. Figures of drainage area given herein include all closed basins, or noncontributing areas, within the area unless otherwise noted.

Drainage basin is a part of the surface of the earth that is occupied by a drainage system, which consists of a surface stream or a body of impounded surface water together with all tributary surface streams and bodies of impounded surface water.

Gage height $(\mathrm{GH})$ is the water-surface elevation referred to in some arbitrary gage data. Gage height is often used interchangeably with the more general term "stage," although gage height is more appropriate when used with a reading on a gage.

Gaging station is a particular site on a stream, canal, lake, or reservoir where systematic observations of hydrologic data are obtained.

GPS is an acronym for global positioning system. 


\section{Abbreviations, Acronyms, and Glossary (continued)}

HWM is an abbreviation for high-water mark.

Instantaneous discharge is the discharge at a particular instant of time.

LANL is the acronym for Los Alamos National Laboratory.

Mean discharge (MEAN) is the arithmetic mean of individual daily mean discharges during a specific period.

National Geodetic Vertical Datum of 1929 (NGVD) is a geodetic datum derived from a general adjustment of the first-order level nets of both the United States and Canada. It was formerly called Sea Level Datum of 1929, or "mean sea level," in this series of reports. Although the datum was derived from the average sea level over a period of many years at 26 tide stations along the Atlantic, Gulf of Mexico, and Pacific coasts, it does not necessarily represent the local mean sea level at any particular place.

NPDES is the acronym for National Pollution Discharge Elimination System.

SR means "State Road."

Stage. See Gage Height.

Stage-discharge relation is the relation between the water-surface elevation, termed "gage height," and the volume of water flowing in a channel per unit of time.

Stream flow is the discharge that occurs in a natural channel.

SWSC is an acronym for sanitary wastewater systems consolidation.

USGS is the acronym for U.S. Geological Survey.

Water year in reports dealing with surface water supply is the 12-month period, October 1 through September 30. The water year is designated by the calendar year in which it ends and which includes 9 of the 12 months. Thus, the year ending September 30, 1980, is called the "1980 water year."

WDR is an acronym for "Water-Data Report" in the "Revised Records" paragraph to refer to annual hydrologic-data reports.

WSP is an acronym for "Water-Supply Paper" in references to previously published reports. 


\title{
Surface Water Data at Los Alamos National Laboratory: 2006 Water Year
}

\author{
by \\ R.P. Romero, D. Ortiz, and G. Kuyumjian
}

\begin{abstract}
The principal investigators collected and computed surface water discharge data from 44 stream-gaging stations that cover most of Los Alamos National Laboratory and one at Bandelier National Monument. Also included are discharge data from three springs- two that flow into Cañon de Valle and one that flows into Water Canyon-and peak flow data for 44 stations.
\end{abstract}

\section{Introduction}

This annual water data report from Los Alamos National Laboratory (LANL) contains flow data from 44 stream-gaging stations that cover most of the Laboratory's property. Data collected on the Laboratory's downstream boundary approximates New Mexico State Road (SR) 4; the upstream boundary is approximated by New Mexico SR 501. Some of the gaging stations are within Laboratory boundaries and were originally installed to assist groups other than the LANS Environmental Programs Water Stewardship Project (EP-WSP) that also conducts site-specific earth science research.

Four stations were added this year, and publication was suspended for two. Station E039 DP Canyon below Meadow and E2455 Pajarito above Three Mile were omitted from this year's publication because of extreme channel changes and lack of hydraulic events to quantify this change.

Water chemistry data from selected storm events occurring at some stations will be published in the 2006 "Los Alamos National Laboratory Environmental Surveillance Report." Those data are also available on the web at the following sites (http://www.lanl.gov/environment/eco/reports. shtml) and (http://wqdbworld.lanl.gov/rptmodules.html).

\section{Station Identification Numbers}

The U.S. Geological Survey (USGS), Water Resources Division, assigns a unique identification number to each stream-gaging station it establishes. All sites numbered since 1950 are part of the downstream-order system. The downstream-order system increases station numbers in the downstream direction along main streams, and in the case of this report, their respective mouths to the Rio Grande. 
This report adheres to the USGS convention of downstream order. Because of the proximity of stations in this network, the first five digits of all station numbers are 08313 . We have replaced this number string with the letter $\mathrm{E}$ in the station number partly to abbreviate and also to accommodate instrumentation.

\section{Data Collection and Computation}

A complete record-gaging station gathers records of stage and discharge measurements from streams or canals. In addition to gathering these stage and discharge measurements, we directly observe factors affecting the stage/discharge relation, consult weather records, and use other information that supplements base data in determining daily flow. Direct readings on a nonrecording gage or from the data logger provide integrated (5-minute) records of stage. We measure discharge with current meters, using methods the USGS adapted as a result of experience accumulated since 1880. Standard textbooks describe these methods, as do WaterSupply Paper 2175 and the US Geological Survey Technique of Water Resources Investigations, Book 3, Chapter A6.

We use stage/discharge relation curves to prepare rating tables that give the discharge for any stage measured at a stream-gaging station. When it is necessary to define discharge extremes outside the range of current meter measurements, we extend the curves using logarithmic plotting, velocity area studies, results of indirect measurements of peak discharge, such as slope area or contracted opening measurements, and computations of flow over dams or weirs, or step backwater techniques.

Daily mean discharges are computed by applying daily mean gage height (stage) to the stage discharge curves or tables. If the stage/discharge relation is subject to change because of frequent or continual change in the physical features that form the control, the daily mean discharge is computed by the shifting-control method. In the shifting-control method, correction factors based on individual discharge measurements and notes by personnel taking the measurements are applied to the gage heights before discharges are determined from the curves or tables.

The shifting-control method is also used if the stage/discharge relation for a station is temporarily changed by the presence of aquatic growth or debris on the control. At some northern stream-gaging stations, the stage/discharge relation is affected by ice in the winter, and it becomes impossible to compute discharge in the usual manner. Discharge for the period of ice effect is computed on the basis of gage height record and occasional winter discharge measurements. Consideration is given to the available information about temperature and precipitation, notes of observations, and comparable discharge records for other stations in the same or nearby basins for comparable periods of time.

For some gaging stations, periods occur when no gage height record is obtained, or the recorded gage height is so faulty that it cannot be used to compute daily discharge or contents. This happens when the recorder stops or otherwise fails to operate properly, intakes are plugged, the float is frozen in the well, etc. For such periods, the daily discharges are estimated on the basis 
of recorded range-in-stage, prior and subsequent records, discharge measurements, weather records, and record comparisons made against other stations in the same or nearby basins. Likewise, daily contents may be estimated from operator logs, prior and subsequent records, inflow-outflow studies, and other information.

\section{Accuracy of Records}

Two factors determine the accuracy of streamflow records,

- stability of the stage-discharge relation or, if the control is unstable, the frequency of discharge measurements, and

- accuracy of measurements or stage, accuracy of discharge measurements, and interpretations of records.

Accuracy attributed to records is noted under "Remarks."

- Excellent-95\% of daily discharges are within 5\% of true value.

- Good-95\% of daily discharges are within $10 \%$ of true value.

- Fair-95\% of daily discharges are within $15 \%$ of true value.

- Poor-records do not meet the criteria mentioned.

Accuracy determination is only based on days with flow.

The number of significant figures used to report daily mean discharges is based solely on the magnitude of the discharge value:

The number of significant figures used to report daily mean discharges is based solely on the magnitude of the discharge value:

\begin{tabular}{|l|l|}
\hline \multicolumn{1}{|c|}{ If-the value $\left(\mathrm{ft}^{3} / \mathrm{s}\right)$ is } & \multicolumn{1}{c|}{ Then-it is reported as } \\
\hline less than $1 \mathrm{ft}^{3} / \mathrm{s}$ & nearest hundredth \\
\hline $1-10 \mathrm{ft}^{3} / \mathrm{s}$ & nearest tenth \\
\hline $10-1,000 \mathrm{ft}^{3} / \mathrm{s}$ & whole number \\
\hline above $1,000 \mathrm{ft}^{3} / \mathrm{s}$ & three significant figures \\
\hline
\end{tabular}

\section{Data Presentation}

The records published in this report are for each gaging station and comprise three parts,

- $\quad$ station analysis summary,

- $\quad$ station manuscript description with photo, and

- data table for the water year (October 1, 2005, to September 30, 2006). 
The station analysis supplements each daily values table and includes a description of monitoring equipment, problems associated with data collection during the water year and other information used to compute stream flow discharge.

The station manuscript provides data under various headings: station location, period of record, average discharge, historical extremes, record accuracy, and other points pertinent to station operation and regulation. Each continuous record of discharge includes the following categories of descriptions.

Location. The most accurate and available maps, plus global positioning system (GPS) technology, provide location information. The location of the gage with respect to the vicinity's cultural and physical features is given, as well as a name that refers to place. For a few stations, the U.S. Army Corps of Engineers or the Water Resources Council (River Mileage Measurement, Bulletin 14, rev. October 1968) provided river mileage. We define left and right banks from the perspective of facing downstream.

Drainage Area. The most accurate and available maps provide drainage area measurements. The accuracy of drainage area measurements varies, depending on the type of map available for this purpose.

Procedure for Creating Gage Station Subwatersheds. Subwatersheds were modeled using the ArcHydro Extension for Arc GIS 9.1. The model derives the subwatersheds from digital elevation data and manual inputs. For the gage station subwatersheds an 8-ft Light Detection and Ranging (LIDAR) digital elevation grid, clipped to the area of analysis, was used as the basis of the ArcHydro model. Manual inputs included "burning" of stream channels and stormwater control systems, "creating walls" around man-made features that block the flow of water, and providing "sink" areas. The "burning" drops the elevation at the specified areas, forcing the water to flow into those areas. "Creating walls" raises the elevation at the specified areas, ensuring that the water cannot flow over that area. "Sinks" are areas of low elevation that have no outlet, such as lakes and ponds. Existing stream channel and stormwater control GIS data were used, with modifications being made based upon field verification.

Once the elevation grid was manually modified using the above inputs ArcHydro determined flow direction, flow accumulation, and stream definition. Stream definition was determined at a resolution of 250 cells or 0.367 acres. Those outputs were then used as inputs in determining subwatershed drainage areas with the gage station locations as the outlet or pour point. Where possible, the resulting drainage areas were then verified against known field conditions. Any necessary changes were made using modifications to the above manual inputs and rerunning the analysis. 
Revised Records. Because of new information, published records occasionally are in revisions that have been published for the station and the water years to which the revisions apply. If a revision did not include daily, monthly, or annual figures of discharge, that fact is noted after the year as follows: (M) means that only instantaneous maximum discharge was revised; (m) means that only the instantaneous minimum was revised; and $(\mathrm{P})$ means that only the peak discharge was revised. If the drainage area has been revised, the report in which the most recently revised figure was first published is given.

Period of Record. The period of record is the time during which published records exist for a station or its equivalent station. An equivalent station is one that was in operation when the present station was not in operation and was located so that records from it can reasonably be considered equivalent to records from the present station.

Gage. This section describes the type of gage in current use. The datum of the current gage referred to in the National Geodetic Vertical Datum of 1929 (NGVD) (see Abbreviations, Acronyms, and Glossary), and a condensed history of the types, locations, and data of previous gages are given under this heading.

Remarks. The text presents information relative to the accuracy of the records, special methods of computation, conditions that affect natural flow at the station, and other pertinent information. Average Discharge. The average discharge is the average of the annual mean discharge published after 5 years of record. Once it is published, it continues as a moving average.

Extremes for Period of Record. Extremes may include maximum and minimum stages and maximum and minimum discharges or content. Unless otherwise qualified, the maximum discharge or content is the instantaneous maximum corresponding to the highest stage that occurred. The highest stage may have been obtained from a graphic or digital recorder, a crest stage gage, or by direct observation of a nonrecording gage. If the maximum stage did not occur on the same day as the maximum discharge or content, it is given separately. Similarly, the minimum is the instantaneous minimum discharge, unless otherwise qualified, and was determined and is reported in the same manner as the maximum.

Extremes outside Period of Record. This section contains information concerning major floods or unusually low flows that occurred outside the stated period of record. The information may have been obtained from other agencies, old data files, newspapers, or local citizens.

Extremes for Current Year. Extremes given here are similar to those for the period of record. The time for occurrence of peaks is expressed in 24-h local standard time. For example, 12:30 A.M. is 0030 and 1:30 P.M. is 1330 . The minimum for the current water year appears in this section.

Data Table of Daily Mean Values. The daily table of discharge records for stream-gaging stations gives the mean discharge for each day of the water year. In the monthly summary for the table, the line headed "Total" gives the sum of the daily figures for each month; the line headed "Mean" gives the average flow in cubic feet per second for the month; and the lines headed "Max" and "Min" give the maximum and minimum daily mean discharges for each month and in acre feet, respectively, in the line headed "Acre-Ft." 


\section{Acknowledgments}

The authors thank the following individuals for their contribution to this report:

M. Alexander, D. Shaull, D. Katzman, S. Veenis, B. McKown, G. Helland, J. Leo Martinez, L. Martinez, T. Morgan, B. Cata and E. Pulliam.

\section{References}

Water-Supply Paper 2175 and the U.S. Geological Survey Technique of Water Resources Investigations, Book 3, Chapter A6.

U.S. Army Corps of Engineers, River Mileage Measurement, Bulletin 14, rev. October 1968.

National Geodetic Vertical Datum of 1929.

Previous Los Alamos National Laboratory reports in this series- "Surface Water Data at Los Alamos National Laboratory" for water years 1995-2004

1995: LA-13177-PR (August 1996)

1996: LA-13234-PR (November 1996)

1997: LA-13403-PR (January 1996)

1998: LA-13551-PR (February 1999)

1999: LA-13706-PR (April 2000)

2000: LA-13814-PR (July 2001)

2001: LA-13905-PR (April 2002)

2002: LA-14019-PR (March 2003)

2003: LA-14131-PR (March 2004)

2004: LA-14211-PR (April 2005)

2005: LA-14239-PR (May 2006) 
Gaging Stations 



\section{Gaging Stations at Los Alamos National Laboratory}

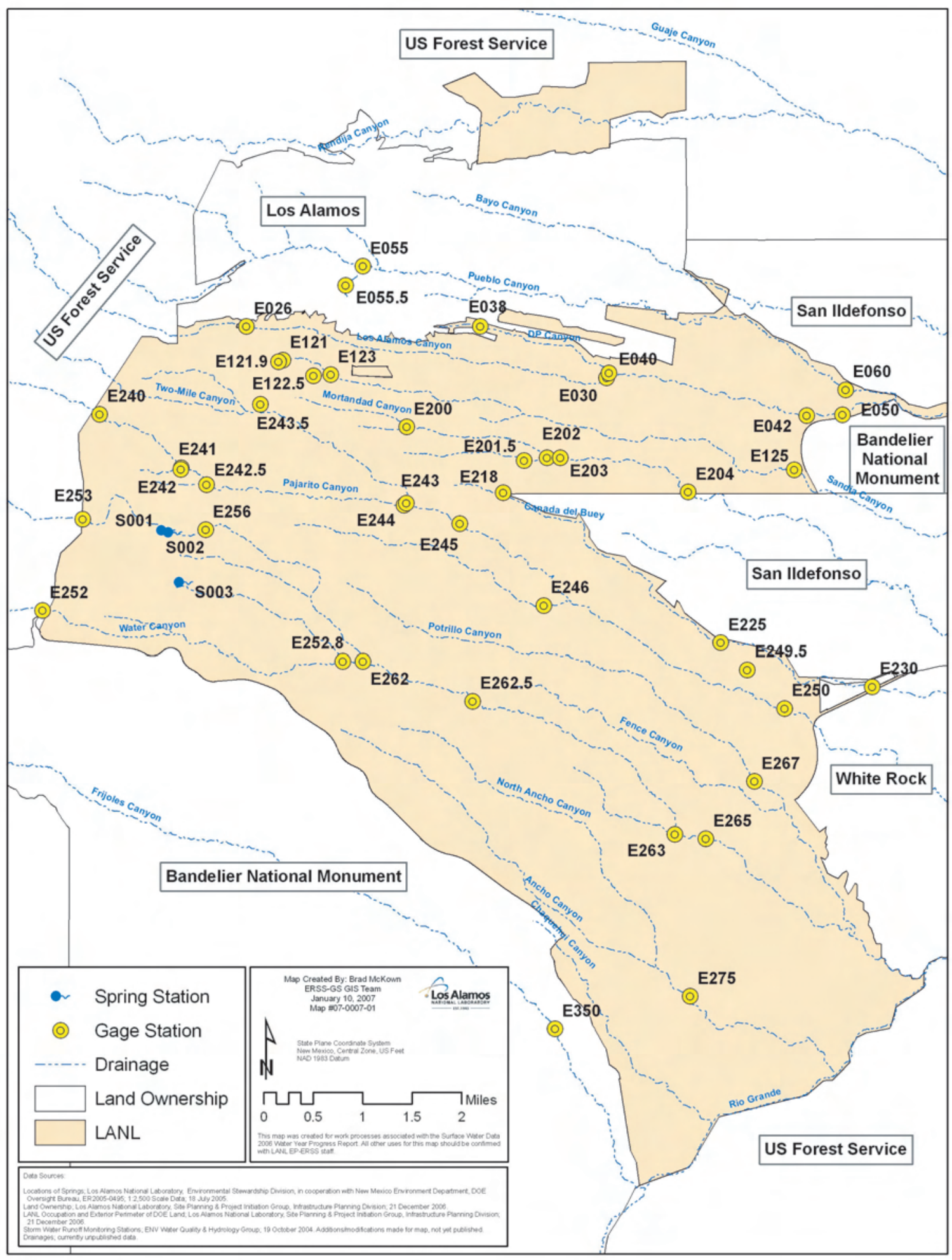




\section{Summary of Discharges from Stream-Monitoring Stations at Los Alamos National Laboratory}

Water Year 2006

October 1, 2005, to September 30, 2006

\begin{tabular}{|c|c|c|c|}
\hline Canyon Sites & Days with Flow & Volume in Ac-Ft & $\begin{array}{c}\text { Instantaneous } \\
\text { Max in } \mathrm{ft}^{3} / \mathrm{s} \\
\end{array}$ \\
\hline E026 Los Alamos Canyon below Ice Rink & 64 & 62 & 83 \\
\hline E030 Los Alamos Canyon above DP Canyon & 55 & 52 & 100 \\
\hline E038 DP Canyon above TA-21 & 74 & 190 & 258 \\
\hline E040 DP Canyon above Los Alamos Canyon & 33 & 39 & 452 \\
\hline E042 Los Alamos Canyon above SR 4 & 22 & 80 & 240 \\
\hline E050 Los Alamos Canyon below LA Weir & 27 & 51 & 252 \\
\hline E055 Pueblo above Acid & 87 & 130 & 1,780 \\
\hline E0555 South Fork Acid Canyon & 62 & 67 & 108 \\
\hline E060 Pueblo above SR 502 & 320 & 481 & 1,930 \\
\hline E121 Sandia Right Fork at Power Plant & 365 & 480 & 60 \\
\hline E1219 Sandia Canyon East of Power Plant & 16 & 0.63 & 3.1 \\
\hline E1225 Sandia Canyon Tributary at Heavy Equipment & 35 & 6.6 & 1.7 \\
\hline E123 Sandia below Wetlands & 365 & 431 & 75 \\
\hline E125 Sandia above SR 4 & 2 & 4.4 & 59 \\
\hline E200 Mortandad below Effluent Canyon & 149 & 87 & 448 \\
\hline E2015 Ten Site above Mortandad & 2 & 11 & 303 \\
\hline E202 Mortandad above Sediment Traps & 7 & 12 & $292 *$ \\
\hline E203 Mortandad below Sediment Traps & 1 & 18 & $220 *$ \\
\hline E204 Mortandad at LANL Boundary & 0 & 0 & 0 \\
\hline E218 Cañada del Buey near TA-46 & 28 & 20 & $228 *$ \\
\hline E225 Cañada del Buey near MDA G & 1 & 0.02 & 0.49 \\
\hline E230 Cañada del Buey above SR 4 & 12 & 6.4 & 54 \\
\hline E240 Pajarito below SR 501 & 14 & 2.2 & 16 \\
\hline E241 Pajarito above Starmers & 90 & 10 & 20 \\
\hline E242 Starmers above Pajarito & 349 & 27 & 17 \\
\hline E2425 La Delfe above Pajarito & 206 & 17 & 12 \\
\hline E243 Pajarito above Two Mile & 96 & 59 & 101 \\
\hline E2435 Two Mile Tributary TA-3 & 38 & 5.0 & 9.6 \\
\hline E244 Two Mile above Pajarito & 103 & 183 & 628 \\
\hline E245 Pajarito above TA-18 & 48 & 113 & 425 \\
\hline E246 Three Mile above Pajarito & 2 & 19 & 536 \\
\hline E2495 MDA - G-7 & 18 & 2.8 & 5.7 \\
\hline E250 Pajarito above SR 4 & 5 & 31 & 206 \\
\hline E252 Water above SR 501 & 365 & 42 & 2.5 \\
\hline E2528 S-Site Canyon above Water & 2 & 6.0 & 77 \\
\hline E253 Cañon de Valle above SR 501 & 0 & 0 & 0.13 \\
\hline E256 Cañon de Valle below MDA P & 198 & 34 & 14 \\
\hline E262 Cañon de Valle above Water & 6 & 5.9 & 59 \\
\hline E2625 Water below MDA AB & 97 & 45 & 195 \\
\hline E263 Water at SR 4 & 12 & 22 & 66 \\
\hline E265 Water below SR 4 & 16 & 19 & 47 \\
\hline E267 Potrillo above SR 4 & 6 & 3.8 & 7.6 \\
\hline E275 Ancho below SR 4 & 10 & 23 & 325 \\
\hline E350 Rio de los Frijoles at Bandelier & 365 & 1,500 & 90 \\
\hline
\end{tabular}




\section{E026 Los Alamos Canyon below Ice Rink}

Location. Lat. 3552'49", long. 106 19'30", in 1/4 SE,1/4 NW sec. 17, T. 19 N, R. 6 E, Los Alamos County, on left bank 0.3 mile upstream from "Rainbow" bridge on Diamond Drive over Los Alamos Canyon and 1.55 miles downstream from Los Alamos Reservoir.

Drainage Area. $7.07 \mathrm{mi}^{2}$.

Period of Record. February 26, 2001, to September 30, 2006.

Revised Record. Drainage Area (this report).

Gage. Data logger with cellular telemetry. Elevation of gage is 7,183 ft above NGVD from GIS 9.1.

Remarks. Water discharge records good, except for estimated daily discharges, which are fair. Flow partially regulated by Los Alamos Reservoir about 1.55 miles upstream. Peak of August 8, 2006 most likely affected by physical removal of debris blocking an upstream culvert during runoff.

Extremes for Period of Record. Maximum discharge $185 \mathrm{ft}^{3} / \mathrm{s}$, August 9, 2001, gage height $1.52 \mathrm{ft}$. No flow most of time.

Extremes for Current Water Year. Maximum discharge $83 \mathrm{ft}^{3} / \mathrm{s}$ at $1225 \mathrm{~h}$, August 8, gage height $1.62 \mathrm{ft}$. (from flood marks). No flow at times.

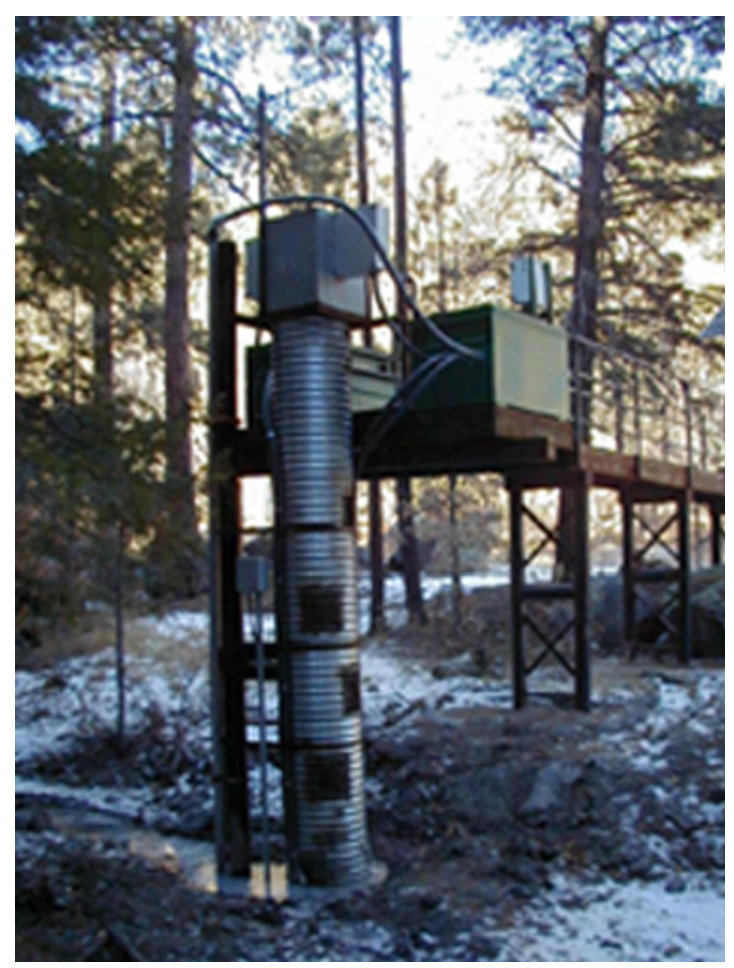




\section{E026 Los Alamos Canyon below Ice Rink}

\section{Station Analysis \\ 2006 Water Year}

Equipment. Sutron 8210 (5-min. interval) with a solar panel battery charging system and shaft encorder float system with cellular phone housed in a National Electric Manufacturing Association (NEMA) shelter on top of a 24" Corrugated Metal Pipe (CMP) well 16-ft.-long attached to a 40-ft. steel walkway on left bank. The station is also equipped with two ISCO samplers for water quality collection and are housed in a 4' x 4' metal box. The data logger triggers all samplers. No provision for measurement above wading stage. All high flow measurement will be by slope-area or critical depth computation methods.

Field Work. The station was visited nineteen times for the purpose of making discharge measurements and/or servicing the instrumentation. Field inspections for the gage are listed under site history files on the Hydstra database. Discharge measurements for the gage are listed under site gauging files on the Hydstra database.

Datum Correction. Level run Nov. 21, 2001, and datum correction applied as detailed on PCS.

Gage-Height Record. The recorder referenced to the inside gave a complete and satisfactory record for the period of record. January 1 to March 7 gage was affected by ice. No flow was reported at E025 for this period.

Rating. The channel at the gage is about $20 \mathrm{ft}$. wide and straight for $20 \mathrm{ft}$. upstreamwhere it bends to the left and then straight for about $150 \mathrm{ft}$. downstream. The streambed through this reach is primary gravel with cobbles. Low flow control is rock and grave riffle $15 \mathrm{ft}$. downstream from gage. Channel is the control for medium and high stages. The build-up and scour of this control leads to changes of shifts during the water year.

Five discharge measurements (No. 39-43) and nineteen inspections were made during the period. All of the measurements listed above indicated a negative shift ranging from -0.02 to -0.08 . These shifts were all applied using several different variable stage shifts prorated in or over storm events.

Rating No. 1 was used from October 1, 2005, to August 4, 2006. Shifts were all minus defined by discharge measurements. Rating No. 2 was developed based on measurement No. 41-43. Measurement No. 42 was a critical depth computation of peak flow.

Flow is partially regulated by Los Alamos Reservoir about 1.5 miles upstream of gage and draining of this reservoir. Gage of reference at this station is the inside (reference point measure). Fall exists at all low/medium flow regimes between staff and well.

Discharge. Discharges were computed from Rating No. 1 and rating No. 2 using variable shifts curves that were defined by the measurements and listed on the work sheet. Periods of lost gage height record were computed from record computation of auxiliary station E025 one-quarter mile upstream. (That station is a 2-ft flume and record is good to excellent.)

Remarks. Records good, except for estimated daily discharges, which are fair. 


\section{E026 Los Alamos Canyon below Ice Rink}

Daily Mean Discharge in Cubic Feet per Second

Water Year October 2005 to September 2006

\begin{tabular}{|c|c|c|c|c|c|c|c|c|c|c|c|c|}
\hline DAY & OCT & NOV & DEC & JAN & FEB & MAR & APR & MAY & JUN & JUL & AUG & SEP \\
\hline 1 & .60 & .09 & 0 & $0^{*}$ & $0^{*}$ & $0^{*}$ & 0 & 0 & 0 & 0 & 0 & .03 \\
\hline 2 & .71 & .04 & 0 & $0^{*}$ & $0^{*}$ & $0^{*}$ & 0 & 0 & 0 & 0 & 0 & 0 \\
\hline 3 & .60 & .02 & 0 & $0^{*}$ & $0^{*}$ & $0^{*}$ & 0 & 0 & 0 & 0 & 0 & 0 \\
\hline 4 & .41 & 0 & 0 & $0^{*}$ & $0^{*}$ & $0^{*}$ & 0 & 0 & 0 & 0 & 0 & 0 \\
\hline 5 & .24 & 0 & 0 & $0^{*}$ & $0^{*}$ & $0^{*}$ & 0 & 0 & 0 & 0 & .51 & 0 \\
\hline 6 & .18 & 0 & 0 & $0^{*}$ & $0^{*}$ & $0^{*}$ & 0 & 0 & 0 & 0 & .49 & .02 \\
\hline 7 & .15 & 0 & 0 & $0^{*}$ & $0^{*}$ & 0 & 0 & 0 & 0 & 0 & .80 & .02 \\
\hline 8 & .12 & 0 & 0 & $0^{*}$ & $0^{*}$ & 0 & 0 & 0 & 0 & 0 & 3.2 & 0 \\
\hline 9 & .18 & 0 & 0 & $0^{*}$ & $0^{*}$ & 0 & 0 & 0 & 0 & 0 & 1.3 & 0 \\
\hline 10 & .22 & 0 & 0 & $0^{*}$ & $0^{*}$ & 0 & 0 & 0 & 0 & 0 & 1.8 & 0 \\
\hline 11 & .20 & 0 & 0 & $0^{*}$ & $0^{*}$ & 0 & 0 & 0 & 0 & 0 & 1.8 & 0 \\
\hline 12 & .18 & 0 & 0 & $0^{*}$ & $0^{*}$ & 0 & 0 & 0 & 0 & 0 & 1.7 & 0 \\
\hline 13 & .15 & 0 & 0 & $0^{*}$ & $0^{*}$ & 0 & 0 & 0 & 0 & 0 & 1.5 & 0 \\
\hline 14 & .19 & 0 & 0 & $0^{*}$ & $0^{*}$ & 0 & 0 & 0 & 0 & 0 & 1.4 & 0 \\
\hline 15 & .25 & 0 & 0 & $0^{*}$ & $0^{*}$ & 0 & 0 & 0 & 0 & 0 & 1.3 & 0 \\
\hline 16 & .24 & 0 & 0 & $0^{*}$ & $0^{*}$ & 0 & 0 & 0 & 0 & 0 & 1.1 & 0 \\
\hline 17 & .20 & 0 & 0 & $0^{*}$ & $0^{*}$ & 0 & 0 & 0 & 0 & 0 & .95 & 0 \\
\hline 18 & .27 & 0 & 0 & $0^{*}$ & $0^{*}$ & 0 & 0 & 0 & 0 & 0 & .86 & 0 \\
\hline 19 & .35 & 0 & 0 & $0^{*}$ & $0^{*}$ & 0 & 0 & 0 & 0 & 0 & .69 & 0 \\
\hline 20 & .27 & 0 & 0 & $0^{*}$ & $0^{*}$ & 0 & 0 & 0 & 0 & 0 & .89 & 0 \\
\hline 21 & .24 & 0 & 0 & $0^{*}$ & $0^{*}$ & 0 & 0 & 0 & 0 & 0 & .69 & 0 \\
\hline 22 & .26 & 0 & 0 & $0^{*}$ & $0^{*}$ & 0 & 0 & 0 & 0 & 0 & .44 & 0 \\
\hline 23 & .27 & 0 & 0 & $0^{*}$ & $0^{*}$ & 0 & 0 & 0 & 0 & 0 & .34 & 0 \\
\hline 24 & .30 & 0 & 0 & $0^{*}$ & $0^{*}$ & 0 & 0 & 0 & 0 & 0 & .35 & 0 \\
\hline 25 & .21 & 0 & 0 & $0^{*}$ & $0^{*}$ & 0 & 0 & 0 & 0 & 0 & .68 & 0 \\
\hline 26 & .18 & 0 & 0 & $0^{*}$ & $0^{*}$ & 0 & 0 & 0 & 0 & 0 & .09 & 0 \\
\hline 27 & .17 & 0 & 0 & $0^{*}$ & $0^{*}$ & 0 & 0 & 0 & 0 & 0 & .08 & 0 \\
\hline 28 & .16 & 0 & 0 & $0^{*}$ & $0^{*}$ & 0 & 0 & 0 & 0 & 0 & .09 & 0 \\
\hline 29 & .15 & 0 & 0 & $0^{*}$ & ------ & 0 & 0 & 0 & 0 & 0 & .08 & 0 \\
\hline 30 & .16 & 0 & 0 & $0^{*}$ & ------ & 0 & 0 & 0 & 0 & 0 & .06 & 0 \\
\hline 31 & .14 & ----- & 0 & $0^{*}$ & ----- & 0 & ------ & 0 & ----- & 0 & .04 & ----- \\
\hline Total & 7.95 & 0.15 & 0 & 0 & 0 & 0 & 0 & 0 & 0 & 0 & 23.23 & 0.07 \\
\hline Mean & .26 & .005 & 0 & 0 & 0 & 0 & 0 & 0 & 0 & 0 & .75 & .002 \\
\hline $\operatorname{Max}$ & .71 & .09 & 0 & 0 & 0 & 0 & 0 & 0 & 0 & 0 & 3.2 & .03 \\
\hline Min & .12 & 0 & 0 & 0 & 0 & 0 & 0 & 0 & 0 & 0 & 0 & 0 \\
\hline Acre-Ft & 16 & .30 & 0 & 0 & 0 & 0 & 0 & 0 & 0 & 0 & 46 & .14 \\
\hline Wtr Year & 2006 & Total & 31.40 & Mean & .086 & & Max & 3.2 & Min & 0 & Acre-Ft & 62 \\
\hline Cal Year & 2005 & Total & 459.76 & Mean & 1.26 & & Max & 5 & Min & 0 & Acre-Ft & 912 \\
\hline
\end{tabular}

* Estimated 


\section{E030 Los Alamos Canyon above DP Canyon}

Location. Lat. 3552'21", long. 106¹5'36", SW 1/4, SE 1/4 sec. 14, T. 19 N, R. 6 E, Los Alamos County, $150 \mathrm{ft}$ upstream from mouth of DP Canyon wash and 2.4 miles upstream from SR 4.

Drainage Area. $8.57 \mathrm{mi}^{2}$.

Period of Record. July 1994 to September 30, 2006.

Revised Record. Drainage Area (this report).

Gage. Data logger with cellular telemetry and concrete control. Elevation of gage is $6,621 \mathrm{ft}$ above NGVD from GIS 9.1.

Remarks. Water discharge records good. Flow partially regulated by Los Alamos Reservoir about 2.5 miles upstream.

Average Discharge. $12 \mathrm{yr}, 0.29 \mathrm{ft}^{3} / \mathrm{s}, 210$ acre-ft/yr.

Extremes Outside Period of Record. Flood of July 31, 1968, was $329 \mathrm{ft}^{3} / \mathrm{s}$ from slope area determination. Gage height was established later at $3.71 \mathrm{ft}$ present datum.

Extremes for Period of Record. Maximum discharge $125 \mathrm{ft}^{3} / \mathrm{s}$, June 22, 2002, gage height $2.88 \mathrm{ft}$ from peak flow computation. No flow most of time.

Extremes for Current Water Year. Maximum discharge $100 \mathrm{ft}^{3} / \mathrm{s}$ on August 8, at $1325 \mathrm{~h}$, gage height $2.65 \mathrm{ft}$. No flow most of time.

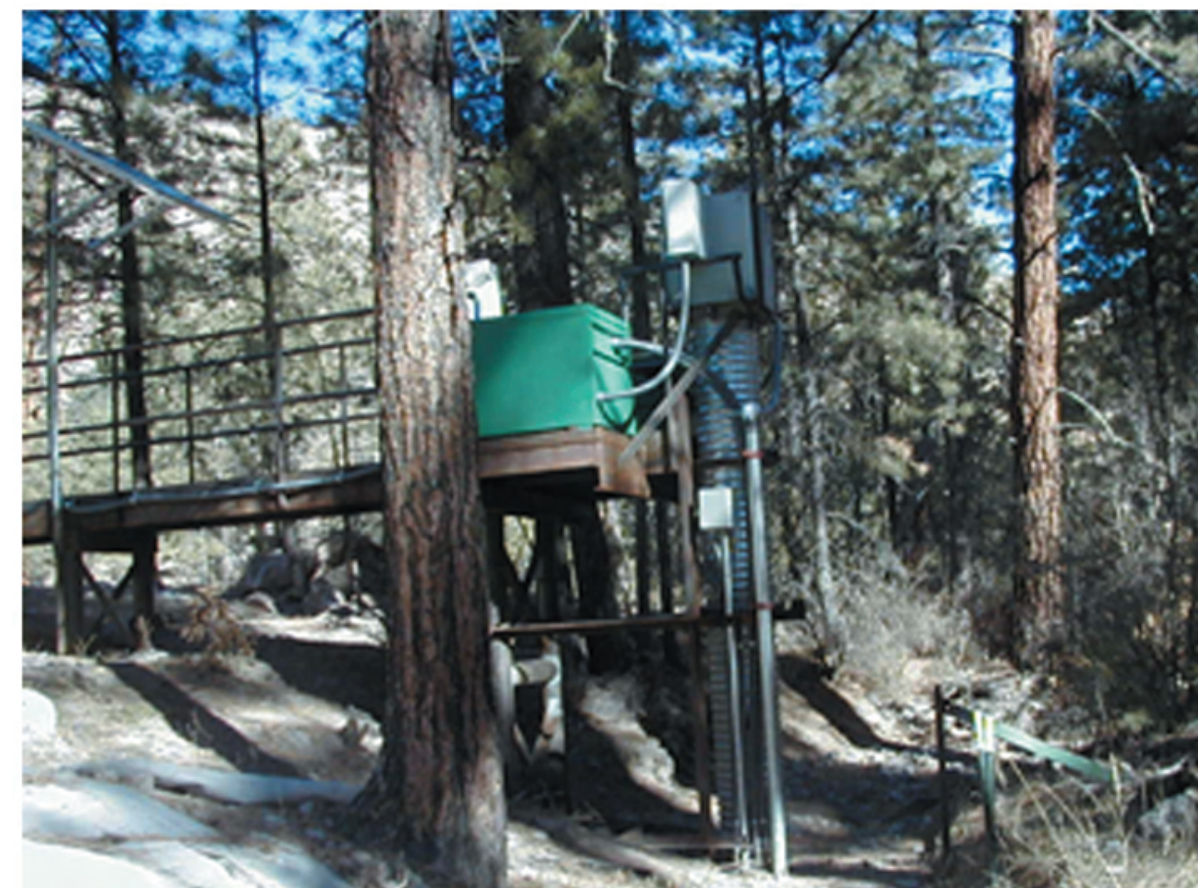




\section{E030 Los Alamos Canyon above DP Canyon \\ Station Analysis \\ 2006 Water Year}

Equipment. Sutron 8210 data logger with quadrature encoder driven by float tape. Data logger has cellular phone with speech and data modem. Reference gage is outside staff. Control is 120 degree sharp-crested weir becoming broad-crested weir when flow breaks out of notch. ISCO brand automatic sampler triggered by data logger is operated in separate shelter. No provision for direct measurements of high flow.

Datum Correction. None

Gage-Height Record. The recorder referenced to the outside gage gave a complete and satisfactory record for the year.

Rating. Streambed is sand and gravel and subject to slight movement during flow events. The channel is straight for 300 feet above gage and 50 feet below. Vegetation on bank is sparse grass.

Seven discharge measurement (Nos. 34-40) and ten inspections were made during the water year. Measurement No. 37 was a slope-area measurement made to verify the upper end of rating curve. Shifts were used on the low point of the "V" diagram. Plus zero shifts were defined by measurements 35 and 36 (-.02 and -0.1 may be from debris on weir). No. 36 had a shift of +0.10 and only used for one day. Positive shifting at low end is from fill in gage pool resulting in approach to notch.

Rating No. 2 was used for the entire water year.

Discharge. Discharge was computed from Rating No. 2 using variable shift diagrams.

Remarks. Records good. 


\section{E030 Los Alamos Canyon above DP Canyon}

Daily Mean Discharge in Cubic Feet per Second

Water Year October 2005 to September 2006

\begin{tabular}{|c|c|c|c|c|c|c|c|c|c|c|c|c|}
\hline DAY & OCT & NOV & DEC & JAN & FEB & MAR & APR & MAY & JUN & JUL & AUG & SEP \\
\hline 1 & .27 & 0 & 0 & 0 & 0 & 0 & 0 & 0 & 0 & 0 & .18 & $\begin{array}{l}.02 \\
\end{array}$ \\
\hline 2 & .27 & 0 & 0 & 0 & 0 & 0 & 0 & 0 & 0 & 0 & 0 & 0 \\
\hline 3 & .23 & 0 & 0 & 0 & 0 & 0 & 0 & 0 & 0 & 0 & 0 & 0 \\
\hline 4 & .14 & 0 & 0 & 0 & 0 & 0 & 0 & 0 & 0 & 0 & 0 & 0 \\
\hline 5 & .05 & 0 & 0 & 0 & 0 & 0 & 0 & 0 & 0 & .12 & .11 & 0 \\
\hline 6 & .05 & 0 & 0 & 0 & 0 & 0 & 0 & 0 & 0 & .02 & .10 & .05 \\
\hline 7 & .05 & 0 & 0 & 0 & 0 & 0 & 0 & 0 & 0 & .03 & 1.5 & .04 \\
\hline 8 & .02 & 0 & 0 & 0 & 0 & 0 & 0 & 0 & 0 & .07 & 5.7 & 0 \\
\hline 9 & .32 & 0 & 0 & 0 & 0 & 0 & 0 & 0 & 0 & .21 & 2.6 & 0 \\
\hline 10 & .32 & 0 & 0 & 0 & 0 & 0 & 0 & 0 & 0 & 0 & 1.7 & 0 \\
\hline 11 & .23 & 0 & 0 & 0 & 0 & 0 & 0 & 0 & 0 & 0 & 1.1 & .20 \\
\hline 12 & .15 & 0 & 0 & 0 & 0 & 0 & 0 & 0 & 0 & 0 & .82 & 0 \\
\hline 13 & .08 & 0 & 0 & 0 & 0 & 0 & 0 & 0 & 0 & 0 & .56 & 0 \\
\hline 14 & .05 & 0 & 0 & 0 & 0 & 0 & 0 & 0 & 0 & 0 & .46 & 0 \\
\hline 15 & .25 & 0 & 0 & 0 & 0 & 0 & 0 & 0 & 0 & 0 & .54 & 0 \\
\hline 16 & .16 & 0 & 0 & 0 & 0 & 0 & 0 & 0 & 0 & 0 & .26 & 0 \\
\hline 17 & .02 & 0 & 0 & 0 & 0 & 0 & 0 & 0 & 0 & 0 & .21 & 0 \\
\hline 18 & .12 & 0 & 0 & 0 & 0 & 0 & 0 & 0 & 0 & 0 & .14 & 0 \\
\hline 19 & .25 & 0 & 0 & 0 & 0 & 0 & 0 & 0 & 0 & 0 & .74 & 0 \\
\hline 20 & .01 & 0 & 0 & 0 & 0 & 0 & 0 & 0 & 0 & 0 & .36 & 0 \\
\hline 21 & 0 & 0 & 0 & 0 & 0 & 0 & 0 & 0 & 0 & 0 & .52 & 0 \\
\hline 22 & 0 & 0 & 0 & 0 & 0 & 0 & 0 & 0 & 0 & 0 & .21 & 0 \\
\hline 23 & 0 & 0 & 0 & 0 & 0 & 0 & 0 & 0 & 0 & 0 & .16 & 0 \\
\hline 24 & 0 & 0 & 0 & 0 & 0 & 0 & 0 & 0 & 0 & 0 & .12 & 0 \\
\hline 25 & 0 & 0 & 0 & 0 & 0 & 0 & 0 & 0 & 0 & 0 & 3.4 & 0 \\
\hline 26 & 0 & 0 & 0 & 0 & 0 & 0 & 0 & 0 & 0 & 0 & .37 & 0 \\
\hline 27 & 0 & 0 & 0 & 0 & 0 & 0 & 0 & 0 & 0 & 0 & .05 & 0 \\
\hline 28 & 0 & 0 & 0 & 0 & 0 & 0 & 0 & 0 & 0 & 0 & .02 & 0 \\
\hline 29 & 0 & 0 & 0 & 0 & ----- & 0 & 0 & 0 & .29 & 0 & 0 & 0 \\
\hline 30 & 0 & 0 & 0 & 0 & ----- & 0 & 0 & 0 & 0 & 0 & 0 & 0 \\
\hline 31 & 0 & ----- & 0 & 0 & ----- & 0 & ----- & 0 & ----- & 0 & 0 & -.-- \\
\hline Total & 3.04 & 0 & 0 & 0 & 0 & 0 & 0 & 0 & 0.29 & 0.45 & 21.93 & 0.31 \\
\hline Mean & .098 & 0 & 0 & 0 & 0 & 0 & 0 & 0 & .010 & .015 & .71 & .010 \\
\hline Max & .32 & 0 & 0 & 0 & 0 & 0 & 0 & 0 & .29 & .21 & 5.7 & .20 \\
\hline Min & 0 & 0 & 0 & 0 & 0 & 0 & 0 & 0 & 0 & 0 & 0 & 0 \\
\hline Acre-Ft & 6.0 & 0 & 0 & 0 & 0 & 0 & 0 & 0 & .58 & .89 & 43 & .61 \\
\hline Wtr Year & 2006 & Total & 26.02 & & & & Max & 5.7 & Min & 0 & Acre-Ft & 52 \\
\hline Cal Year & 2005 & Total & 372.75 & & 1. & & Max & 7.2 & Min & 0 & Acre-Ft & 739 \\
\hline
\end{tabular}




\section{E038 DP Canyon above TA-21}

Location. Lat. 35'52'49", long. 106¹6'58", in SE 1/4 sec. 13, T. 19 N, R. 6 E, Los Alamos County, on left bank 1.3 miles west of SR 502.

Drainage Area. $0.22 \mathrm{mi}^{2}$.

Period of Record. April 26, 2000, to September 30, 2006

Revised Record. Drainage Area (this report)

Average Discharge. 6 years, $0.14 \mathrm{ft}^{3} / \mathrm{s}, 101$ acre- $\mathrm{ft} / \mathrm{yr}$.

Gage. Data logger with cellular telemetry. Elevation of gage is 7,087 ft above NGVD from GIS 9.1.

Remarks. Records fair, except for estimated daily discharges, which are poor.

Extremes for Period of Record. Maximum discharge $295 \mathrm{ft}^{3} / \mathrm{s}$, July 24, 2004, gage height $4.36 \mathrm{ft}$ from rating curve extended above $10 \mathrm{ft}^{3} / \mathrm{s}$ on basis of peak flow computations. No flow most of time.

Extremes for Current Water Year. Maximum discharge $258 \mathrm{ft}^{3} / \mathrm{s}$, August 8, at $1215 \mathrm{~h}$, gage height $4.20 \mathrm{ft}$. (from slope area computation). No flow most of time.

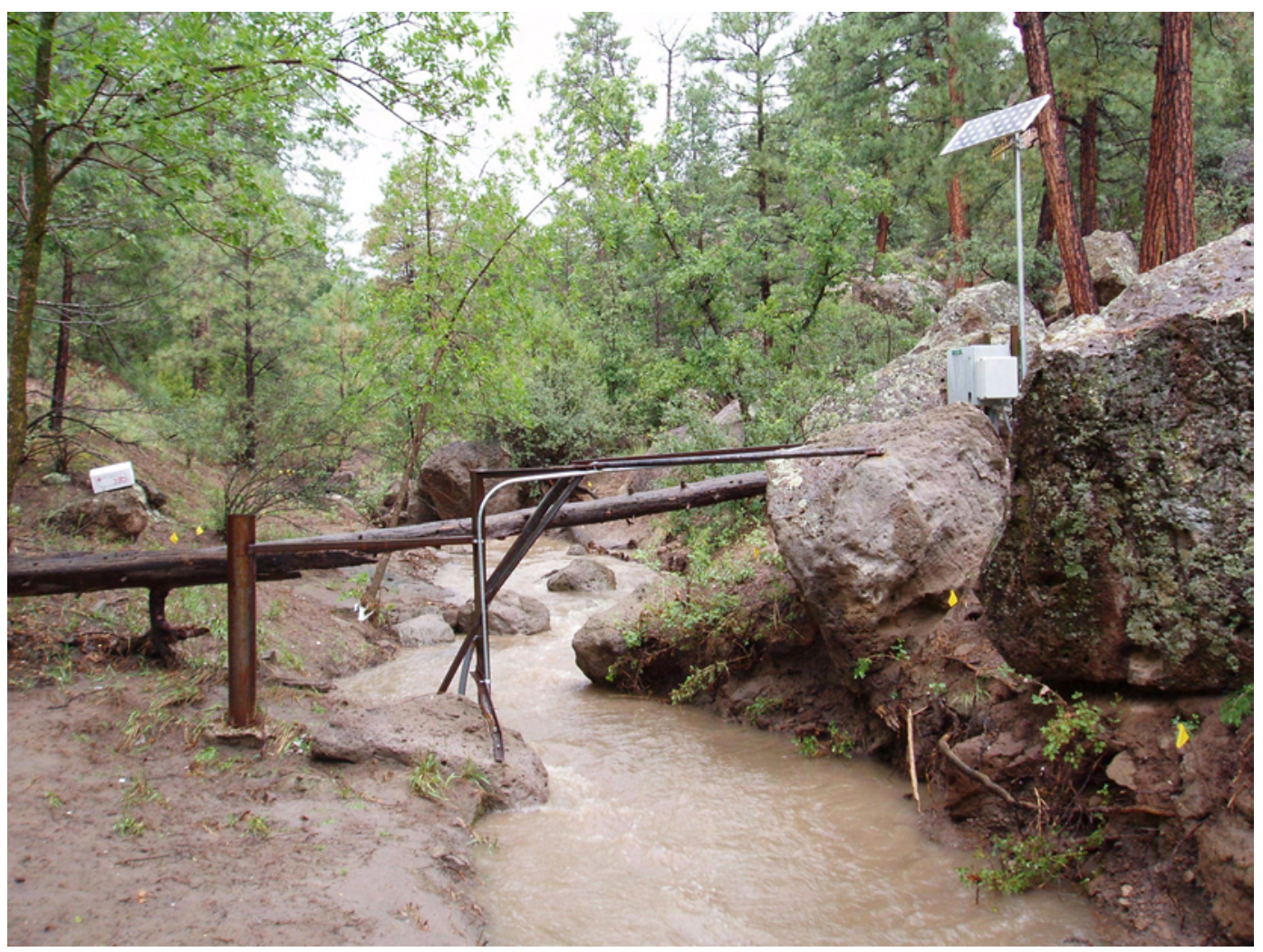




\section{E038 DP Canyon above TA-21}

Station Analysis

2006 Water Year

Equipment. Sutron 8210 data logger (5-min. interval) with a solar panel battery charging system and a milltronics probe mounted on H-beam span on left bank. The equipment is housed in a $24^{\prime} \times 24^{\prime} \times 30^{\prime}$ NEMA shelter. A Sutron accububble self-contained bubbler system was installed on April 16, 2004. The station is also equipped with an ISCO pump sampler for water quality collection in a 4' $\times 4^{\prime}$ metal box. An outside staff gage is available for reference. No provision for discharge measurements above wading stage. All high-flow measurement will be by slope-area or peak-flow computation methods.

Milltronics probe was removed April of 2006.

Field Work. The station was visited eighteen times for the purpose of making a discharge measurement and/or servicing the instrumentation. Field inspections for the gage are listed under site history files on the Hydstra database. Discharge measurements for the gage are listed under site gauging files on the Hydstra database.

Datum Correction. None from levels.

Gage-Height Record. The data logger referenced to the outside gage gave a complete and satisfactory record for the year. Some days had to be reworked when stream channel silted on recession.

Rating. The channel is about $10 \mathrm{ft}$. wide and straight for about $30 \mathrm{ft}$. upstream and downstream. The streambed through this reach is primary sand, gravel, and larger boulder. Low flow control is a rock outcrop downstream from gage about $5 \mathrm{ft}$. Channel control for medium and high stages.

Eighteen inspections were made this water year. Measurement No. 5 was used in this analysis due to poor measurement conditions. All inspections of no flow were used to develop a "V" diagram shift needed to adjust for point of zero flow (PZF).

Peak of record was recorded and verified for flood of August 8.

Discharge. Rating No. 2 was used with "V" diagrams to compute this record.

Remarks. Records good. 
E038 DP Canyon above TA-21

Daily Mean Discharge in Cubic Feet per Second

Water Year October 2005 to September 2006

\begin{tabular}{|c|c|c|c|c|c|c|c|c|c|c|c|c|}
\hline DAY & OCT & NOV & DEC & JAN & FEB & MAR & APR & MAY & JUN & JUL & AUG & SEP \\
\hline 1 & 0 & 0 & 0 & 0 & 0 & 0 & 0 & 0 & 0 & .09 & 5.1 & .56 \\
\hline 2 & .42 & 0 & 0 & 0 & 0 & 0 & 0 & 0 & 0 & .60 & .50 & .59 \\
\hline 3 & .01 & 0 & 0 & 0 & 0 & 0 & 0 & 0 & 0 & 1.3 & .25 & .01 \\
\hline 4 & 0 & 0 & 0 & 0 & 0 & 0 & 0 & 0 & 0 & .63 & 2.0 & 0 \\
\hline 5 & 0 & 0 & 0 & 0 & 0 & 0 & .42 & 0 & 0 & 1.8 & 3.7 & 0 \\
\hline 6 & 0 & 0 & 0 & 0 & 0 & 0 & .02 & .25 & 0 & 1.1 & 1.7 & 1.1 \\
\hline 7 & 0 & 0 & 0 & 0 & 0 & 0 & 0 & .02 & 0 & .15 & 6.4 & .73 \\
\hline 8 & 0 & 0 & 0 & 0 & 0 & 0 & 0 & 0 & 0 & 1.0 & 12 & .74 \\
\hline 9 & 0 & 0 & 0 & 0 & 0 & 0 & 0 & 0 & .09 & 1.7 & 3.0 & .82 \\
\hline 10 & 0 & 0 & 0 & 0 & 0 & 0 & 0 & 0 & 0 & .41 & .30 & .66 \\
\hline 11 & 0 & 0 & 0 & 0 & 0 & 0 & 0 & 0 & 0 & .12 & 0 & 3.8 \\
\hline 12 & 0 & 0 & 0 & 0 & 0 & .13 & 0 & 0 & 0 & 0 & 2.6 & 1.3 \\
\hline 13 & 0 & 0 & 0 & 0 & 0 & 0 & 0 & 0 & 0 & 0 & 2.5 & .03 \\
\hline 14 & 0 & 0 & 0 & 0 & 0 & 0 & 0 & 0 & 0 & 0 & 3.0 & 0 \\
\hline 15 & 0 & 0 & 0 & 0 & 0 & 0 & 0 & 0 & 0 & 0 & 1.6 & 1.2 \\
\hline 16 & 0 & 0 & 0 & 0 & 0 & 0 & 0 & 0 & 0 & 0 & .60 & .71 \\
\hline 17 & 0 & 0 & 0 & 0 & 0 & 0 & 0 & 0 & 0 & 0 & 0 & 0 \\
\hline 18 & 0 & 0 & 0 & 0 & 0 & 0 & 0 & 0 & 0 & 0 & 0 & 0 \\
\hline 19 & 0 & 0 & 0 & 0 & 0 & 0 & 0 & 0 & 0 & 0 & 1.9 & 0 \\
\hline 20 & 0 & 0 & 0 & 0 & 0 & 0 & 0 & 0 & 0 & 0 & 1.6 & 1.1 \\
\hline 21 & 0 & 0 & 0 & 0 & 0 & 0 & 0 & 0 & 0 & .50 & 1.7 & 1.3 \\
\hline 22 & 0 & 0 & 0 & 0 & 0 & 0 & 0 & 0 & .56 & .26 & .43 & .12 \\
\hline 23 & 0 & 0 & 0 & 0 & 0 & 0 & 0 & 0 & 0 & 0 & .06 & 0 \\
\hline 24 & 0 & 0 & 0 & 0 & 0 & 0 & 0 & 0 & 0 & 0 & 0 & 0 \\
\hline 25 & 0 & 0 & 0 & 0 & 0 & 0 & 0 & 0 & 0 & 0 & 9.0 & 0 \\
\hline 26 & 0 & 0 & 0 & 0 & 0 & 0 & 0 & 0 & .12 & .68 & 1.5 & 0 \\
\hline 27 & 0 & 0 & 0 & 0 & 0 & 0 & 0 & 0 & .01 & .42 & .63 & 0 \\
\hline 28 & 0 & 0 & 0 & 0 & 0 & .17 & .08 & 0 & .01 & .19 & 0 & 0 \\
\hline 29 & 0 & 0 & 0 & 0 & ------ & 0 & .18 & 0 & 4.7 & .36 & 0 & 0 \\
\hline 30 & 0 & 0 & 0 & 0 & ------ & 0 & 0 & 0 & .36 & .03 & 0 & 0 \\
\hline 31 & 0 & ------ & 0 & 0 & ------- & 0 & ------ & 0 & ------ & 0 & 0 & ----. \\
\hline Total & 0.43 & 0 & 0 & 0 & 0 & 0.30 & 0.70 & 0.27 & 5.85 & 11.34 & 62.07 & 14.77 \\
\hline Mean & .014 & 0 & 0 & 0 & 0 & .010 & .023 & .009 & .20 & .37 & 2.00 & .49 \\
\hline Max & .42 & 0 & 0 & 0 & 0 & .17 & .42 & .25 & 4.7 & 1.8 & 12 & 3.8 \\
\hline Min & 0 & 0 & 0 & 0 & 0 & 0 & 0 & 0 & 0 & 0 & 0 & 0 \\
\hline Acre-Ft & .85 & 0 & 0 & 0 & 0 & .60 & 1.4 & .54 & 12 & 22 & 123 & 29 \\
\hline Wtr Year & 2006 & Total & 95.73 & Mean & .2 & & Max & 12 & Min & 0 & Acre-Ft & 190 \\
\hline Cal Year & 2005 & Total & 50.99 & Mean & .1 & & $\operatorname{Max}$ & 6.8 & Min & 0 & Acre-Ft & 101 \\
\hline
\end{tabular}




\section{E040 DP Canyon above Los Alamos Canyon}

Location. Lat. 3552'24", long. 106¹5'34", SW 1/4 sec. 14, T. 19 N, R. 6 E, Los Alamos County, on right bank, $150 \mathrm{ft}$ upstream from confluence of DP Canyon and Los Alamos Canyon, and 2.4 miles upstream from SR 4.

Drainage Area. $0.60 \mathrm{mi}^{2}$.

Period of Record. May 1999 to September 30, 2006.

Revised Record. Drainage Area (this report).

Gage. Data logger with cellular telemetry and concrete control. Elevation of gage is 6,620 $\mathrm{ft}$ above NGVD from GIS 9.1.

Remarks. Water discharge records good, except for estimated daily discharges, which are poor.

Average Discharge. $7 \mathrm{yr}, 0.036 \mathrm{ft}^{3} / \mathrm{s}, 26$ acre-ft/yr.

Extremes for Period of Record. Maximum discharge $452 \mathrm{ft}^{3} / \mathrm{s}$, August 8, 2006, gage height $5.65 \mathrm{ft}$ (from slope area measurement). No flow most of time.

Extremes for Current Water Year. Maximum discharge $452 \mathrm{ft}^{3} / \mathrm{s}$ at $1250 \mathrm{~h}$, August 8, gage height $5.65 \mathrm{ft}$ (from slope area measurement). No flow most of time.

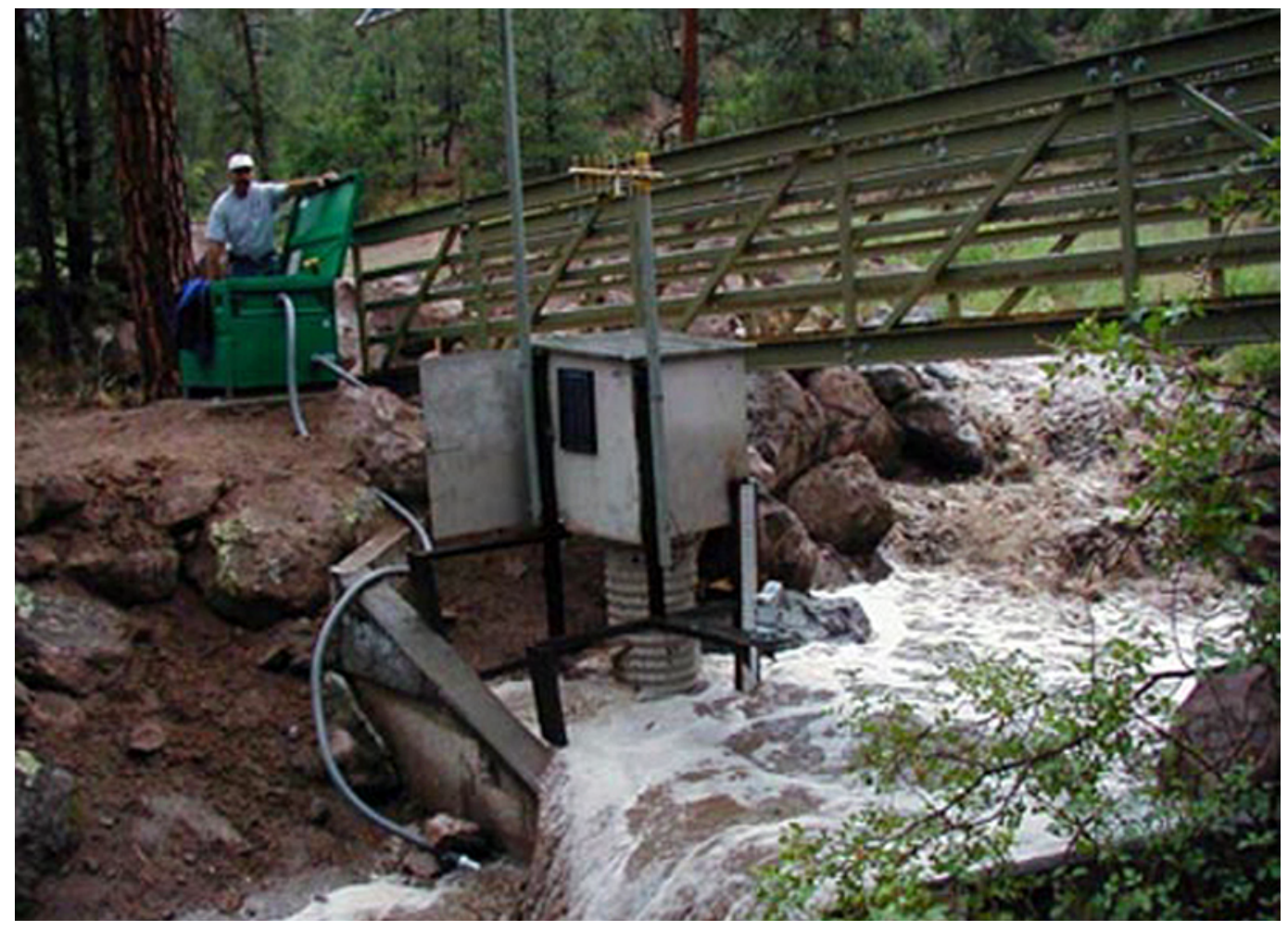




\section{E040 DP Canyon above Los Alamos Canyon \\ Station Analysis \\ 2006 Water Year}

Equipment. Sutron 8210 data logger (5-min. interval) with cellular phone and speech modem housed in a $36^{\prime \prime} \times 36^{\prime \prime} \times 36^{\prime \prime}$ metal shelter on right bank. The stage sensor is a milltronics sonic probe mounted on an H-beam spanning into stream. The system is charged by a solar panel. The station is also equipped with an ISCO pump sampler for water quality collection in a $4^{\prime} \times 4^{\prime}$ metal box that is triggered by the data logger. An outside staff is available for reference. High flow measurements can be made from bridge upstream from gage.

Field Work. The station was visited nineteen times for the purpose of making a discharge measurement and/or servicing the instrumentation. Field inspections for the gage are listed under site history files on the Hydstra database. Discharge measurements for the gage are listed under site gauging files on the Hydstra database.

Datum Correction. None from levels. Corrections applied July 20 to September 30 were essentially pen corrections.

Gage-Height Record. The data logger referenced to the outside staff gave a complete and satisfactory record.

Rating. The channel is about 15 feet wide, bends to the right above gage, and straight for about 100 feet downstream. The streambed through this reach is primarily sand with large boulders. The control at this site is a concrete control with a $\mathrm{V}$ notch in the middle for low flow. Channel control for medium to high flows.

Rating No. 3 was used and redrawn to peak of record slope area computation.

Rating No. 3 is good up to $30 \mathrm{cfs}$ and fair above that.

Three discharge measurements (No. 13-15) were made during the year.

Discharge. Rating No. 3 was used to compute the record.

Remarks. Records good to fair. 


\section{E040 DP Canyon above Los Alamos Canyon}

Daily Mean Discharge in Cubic Feet per Second

Water Year October 2005 to September 2006

\begin{tabular}{|c|c|c|c|c|c|c|c|c|c|c|c|c|}
\hline DAY & OCT & NOV & DEC & JAN & FEB & MAR & APR & MAY & JUN & JUL & AUG & SEP \\
\hline 1 & 0 & 0 & 0 & 0 & 0 & 0 & 0 & 0 & 0 & 0 & 1.9 & 0 \\
\hline 2 & 0 & 0 & 0 & 0 & 0 & 0 & 0 & 0 & 0 & 0 & 0 & 0 \\
\hline 3 & 0 & 0 & 0 & 0 & 0 & 0 & 0 & 0 & 0 & .15 & 0 & 0 \\
\hline 4 & 0 & 0 & 0 & 0 & 0 & 0 & 0 & 0 & 0 & 0 & 0 & 0 \\
\hline 5 & 0 & 0 & 0 & 0 & 0 & 0 & 0 & 0 & 0 & 1.0 & .96 & 0 \\
\hline 6 & 0 & 0 & 0 & 0 & 0 & 0 & 0 & 0 & 0 & .24 & .18 & 0 \\
\hline 7 & 0 & 0 & 0 & 0 & 0 & 0 & 0 & 0 & 0 & 0 & .44 & 0 \\
\hline 8 & 0 & 0 & 0 & 0 & 0 & 0 & 0 & 0 & 0 & .27 & 7.2 & 0 \\
\hline 9 & .18 & 0 & 0 & 0 & 0 & 0 & 0 & 0 & 0 & 2.3 & 0 & 0 \\
\hline 10 & .06 & 0 & 0 & 0 & 0 & 0 & 0 & 0 & 0 & $0^{*}$ & 0 & 0 \\
\hline 11 & 0 & 0 & 0 & 0 & 0 & 0 & 0 & 0 & 0 & $0^{*}$ & .40 & .04 \\
\hline 12 & 0 & 0 & 0 & 0 & 0 & 0 & 0 & 0 & 0 & $0^{*}$ & .11 & 0 \\
\hline 13 & 0 & 0 & 0 & 0 & 0 & 0 & 0 & 0 & 0 & $0^{*}$ & .06 & 0 \\
\hline 14 & 0 & 0 & 0 & 0 & 0 & 0 & 0 & 0 & 0 & $0^{*}$ & 0 & 0 \\
\hline 15 & .16 & 0 & 0 & 0 & 0 & 0 & 0 & 0 & 0 & $0^{*}$ & 0 & 0 \\
\hline 16 & 0 & 0 & 0 & 0 & 0 & 0 & 0 & 0 & 0 & $0^{*}$ & 0 & 0 \\
\hline 17 & 0 & 0 & 0 & 0 & 0 & 0 & 0 & 0 & 0 & $0^{*}$ & 0 & 0 \\
\hline 18 & 0 & 0 & 0 & 0 & 0 & 0 & 0 & 0 & 0 & .41 & 0 & 0 \\
\hline 19 & .35 & 0 & 0 & 0 & 0 & 0 & 0 & 0 & 0 & 0 & .03 & 0 \\
\hline 20 & 0 & 0 & 0 & 0 & 0 & 0 & 0 & 0 & 0 & .40 & 0 & 0 \\
\hline 21 & 0 & 0 & 0 & 0 & 0 & 0 & 0 & 0 & 0 & 0 & .09 & 0 \\
\hline 22 & 0 & 0 & 0 & 0 & 0 & 0 & 0 & 0 & 0 & 0 & .02 & 0 \\
\hline 23 & 0 & 0 & 0 & 0 & 0 & 0 & 0 & 0 & 0 & 0 & 0 & 0 \\
\hline 24 & 0 & 0 & 0 & 0 & 0 & 0 & 0 & 0 & 0 & 0 & 0 & 0 \\
\hline 25 & 0 & 0 & 0 & 0 & 0 & 0 & 0 & 0 & 0 & 0 & .33 & 0 \\
\hline 26 & 0 & 0 & 0 & 0 & 0 & 0 & 0 & 0 & 0 & 0 & 0 & 0 \\
\hline 27 & 0 & 0 & 0 & 0 & 0 & 0 & 0 & 0 & 0 & 0 & 0 & 0 \\
\hline 28 & 0 & 0 & 0 & 0 & 0 & 0 & 0 & 0 & 0 & 0 & 0 & 0 \\
\hline 29 & 0 & 0 & 0 & 0 & ------ & 0 & 0 & 0 & 2.0 & 0 & 0 & 0 \\
\hline 30 & 0 & 0 & 0 & 0 & ------ & 0 & 0 & 0 & 0 & 0 & 0 & 0 \\
\hline 31 & 0 & ----- & 0 & 0 & ----- & 0 & ----- & 0 & ----- & 0 & 0 & --- \\
\hline Total & 0.75 & 0 & 0 & 0 & 0 & 0 & 0 & 0 & 2.0 & 4.77 & 11.72 & 0.04 \\
\hline Mean & .024 & 0 & 0 & 0 & 0 & 0 & 0 & 0 & .067 & .15 & .38 & .001 \\
\hline Max & .35 & 0 & 0 & 0 & 0 & 0 & 0 & 0 & 2.0 & 2.3 & 7.2 & .04 \\
\hline Min & 0 & 0 & 0 & 0 & 0 & 0 & 0 & 0 & 0 & 0 & 0 & 0 \\
\hline Acre-Ft & 1.5 & 0 & 0 & 0 & 0 & 0 & 0 & 0 & 4.0 & 9.5 & 23 & .08 \\
\hline Wtr Year & 2006 & & & & & .053 & Max & 7.2 & Min & 0 & Acre-Ft & 39 \\
\hline Cal Year & 2005 & & & & & .099 & $\operatorname{Max}$ & 5.3 & Min & 0 & Acre-Ft & 72 \\
\hline
\end{tabular}




\section{E042 Los Alamos Canyon above SR 4}

Location. Lat. $35^{\circ} 52^{\prime} 01^{\prime \prime}$, long. $106^{\circ} 13^{\prime} 25^{\prime \prime}$, in SW 1/4 sec. 20, T. 19 N, R. 7 E, Santa Fe County, on right bank, 0.25 mile upstream from SR 4, 2.7 miles northwest of White Rock, New Mexico, 3.9 miles east of Los Alamos, and 13.5 miles southwest of Española.

Drainage Area. $10.11 \mathrm{mi}^{2}$.

Period of Record. November, 1970, to June, 1971, October, 1991, to September 30, 2006.

Revised Record. Drainage Area (this report).

Gage. Data logger with cellular telemetry and concrete control. Elevation of gage is 6,300 $\mathrm{ft}$ above NGVD from GIS 9.1.

Remarks. Water discharge records good. Flow partially regulated by Los Alamos Reservoir about 7.8 miles upstream.

Average Discharge. $12 \mathrm{yr}, 0.27 \mathrm{ft}^{3} / \mathrm{s}, 196$ acre- $\mathrm{ft} / \mathrm{yr}$.

Extremes for Period of Record. Maximum discharge $240 \mathrm{ft}^{3} / \mathrm{s}$, August 08, 2006, gage height $3.76 \mathrm{ft}$. (from flood marks). No flow at times.

Extremes for Current Water Year. Maximum discharge $240 \mathrm{ft}^{3} / \mathrm{s}$ at $1320 \mathrm{~h}$, August 8, gage height $3.76 \mathrm{ft}$.(from flood marks). No flow most of time.

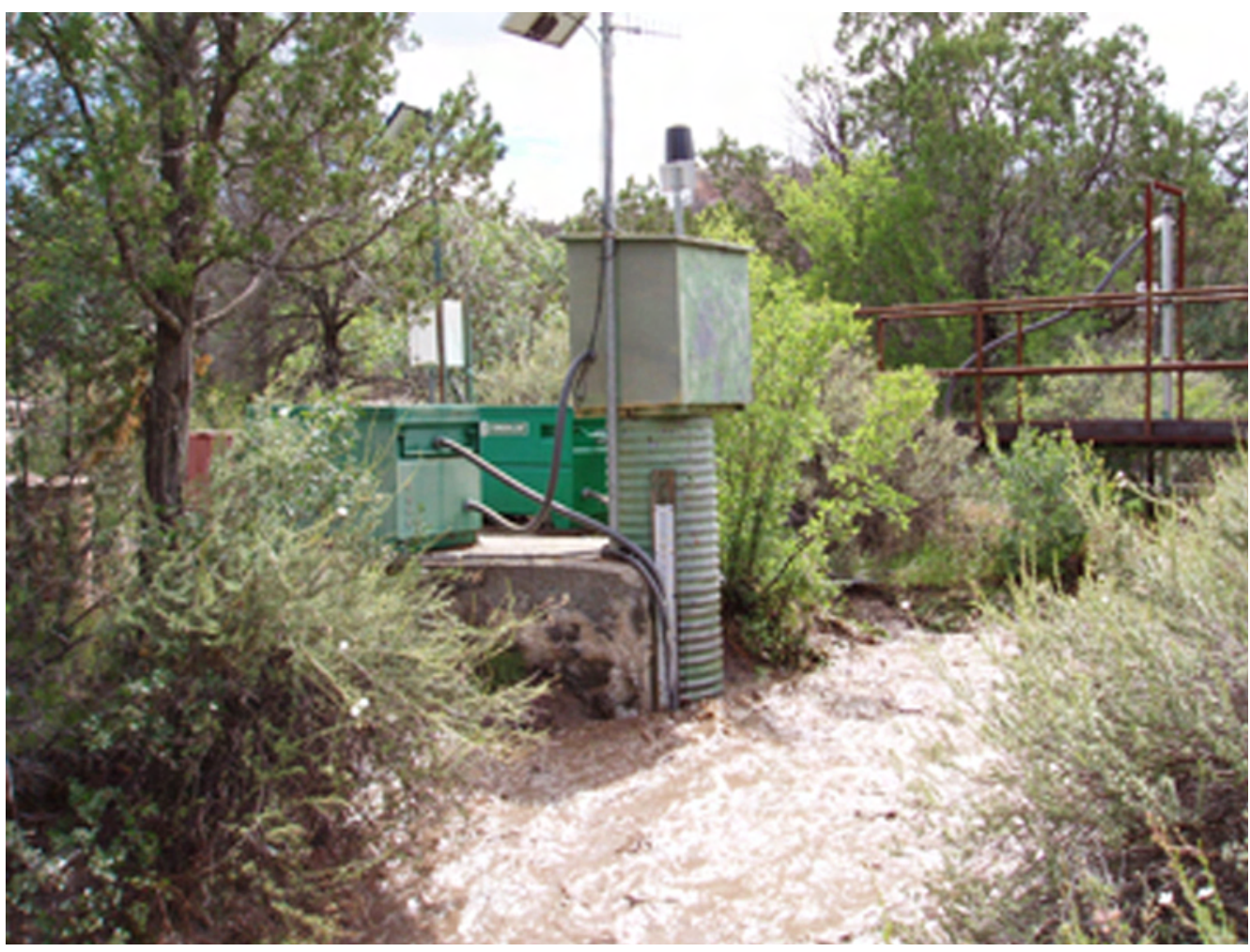




\section{E042 Los Alamos Canyon above SR 4 \\ Station Analysis \\ 2006 Water Year}

Equipment. Sutron 8210 data logger with quadrature encoder driven by float tape in stilling well. Data logger is equipped with cellular phone and speech modem. Control is broadcrested weir that has deteriorated somewhat over the years, but is still fairly stable. Footbridge is available for high flow discharge measurements. An ISCO-brand sampler is housed in an auxiliary shelter and is stage triggered by the Surtron data logger.

Datum Correction. None

Gage-Height Record. Record was complete for the water year, except for June 29-30 and July 9 when data logger malfunctioned.

Rating. Streambed is sand and gravel and channel is straight for over 150 feet above and below broad-crested weir. Fill and scour, mostly fill, of the gage pool occurs on most flow events.

Four discharge measurements (No. 31-34) were made, and twenty inspections of no flow were made. Measurement No. 34 was a critical depth computation. Shifts were small and variable and applied only to low flows.

Rating 2 was developed from current measurements and critical depth computations for peak of record (this year). No shifts applied above $1.0 \mathrm{ft}^{3} / \mathrm{s}$.

Discharge. Discharge computed from Rating 2 using V diagrams with no shifts on high flows or even above $1.0 \mathrm{cfs}$.

Annual peak was recorded and verified with flood marks and is the peak of record.

Remarks. Records good, except for estimated daily discharges, which are poor. 


\section{E042 Los Alamos Canyon above SR 4}

Daily Mean Discharge in Cubic Feet per Second

Water Year October 2005 to September 2006

\begin{tabular}{|c|c|c|c|c|c|c|c|c|c|c|c|c|}
\hline DAY & OCT & NOV & DEC & JAN & FEB & MAR & APR & MAY & JUN & JUL & AUG & SEP \\
\hline 1 & 0 & 0 & 0 & 0 & 0 & 0 & 0 & 0 & 0 & 0 & 2.4 & 0 \\
\hline 2 & 0 & 0 & 0 & 0 & 0 & 0 & 0 & 0 & 0 & 0 & .06 & 0 \\
\hline 3 & 0 & 0 & 0 & 0 & 0 & 0 & 0 & 0 & 0 & .50 & .05 & 0 \\
\hline 4 & 0 & 0 & 0 & 0 & 0 & 0 & 0 & 0 & 0 & .50 & .05 & 0 \\
\hline 5 & 0 & 0 & 0 & 0 & 0 & 0 & 0 & 0 & 0 & 3.4 & 2.0 & 0 \\
\hline 6 & 0 & 0 & 0 & 0 & 0 & 0 & 0 & 0 & 0 & .12 & .22 & 0 \\
\hline 7 & 0 & 0 & 0 & 0 & 0 & 0 & 0 & 0 & 0 & 0 & 4.1 & 0 \\
\hline 8 & 0 & 0 & 0 & 0 & 0 & 0 & 0 & 0 & 0 & 0 & 12 & 0 \\
\hline 9 & 0 & 0 & 0 & 0 & 0 & 0 & 0 & 0 & 0 & $1.9^{*}$ & 0 & 0 \\
\hline 10 & 0 & 0 & 0 & 0 & 0 & 0 & 0 & 0 & 0 & 0 & 0 & 0 \\
\hline 11 & 0 & 0 & 0 & 0 & 0 & 0 & 0 & 0 & 0 & 0 & 0 & .45 \\
\hline 12 & 0 & 0 & 0 & 0 & 0 & 0 & 0 & 0 & 0 & 0 & .12 & 0 \\
\hline 13 & 0 & 0 & 0 & 0 & 0 & 0 & 0 & 0 & 0 & 0 & 0 & 0 \\
\hline 14 & 0 & 0 & 0 & 0 & 0 & 0 & 0 & 0 & 0 & 0 & .11 & 0 \\
\hline 15 & 0 & 0 & 0 & 0 & 0 & 0 & 0 & 0 & 0 & 0 & .90 & 0 \\
\hline 16 & 0 & 0 & 0 & 0 & 0 & 0 & 0 & 0 & 0 & 0 & 0 & 0 \\
\hline 17 & 0 & 0 & 0 & 0 & 0 & 0 & 0 & 0 & 0 & 0 & 0 & 0 \\
\hline 18 & 0 & 0 & 0 & 0 & 0 & 0 & 0 & 0 & 0 & 0 & 0 & 0 \\
\hline 19 & .28 & 0 & 0 & 0 & 0 & 0 & 0 & 0 & 0 & 0 & 1.0 & 0 \\
\hline 20 & 0 & 0 & 0 & 0 & 0 & 0 & 0 & 0 & 0 & 0 & .21 & 0 \\
\hline 21 & 0 & 0 & 0 & 0 & 0 & 0 & 0 & 0 & 0 & 0 & .95 & 0 \\
\hline 22 & 0 & 0 & 0 & 0 & 0 & 0 & 0 & 0 & 0 & 0 & 0 & 0 \\
\hline 23 & 0 & 0 & 0 & 0 & 0 & 0 & 0 & 0 & 0 & 0 & 0 & 0 \\
\hline 24 & 0 & 0 & 0 & 0 & 0 & 0 & 0 & 0 & 0 & 0 & 0 & 0 \\
\hline 25 & 0 & 0 & 0 & 0 & 0 & 0 & 0 & 0 & 0 & 0 & 11 & 0 \\
\hline 26 & 0 & 0 & 0 & 0 & 0 & 0 & 0 & 0 & 0 & 0 & 0 & 0 \\
\hline 27 & 0 & 0 & 0 & 0 & 0 & 0 & 0 & 0 & 0 & 0 & 0 & 0 \\
\hline 28 & 0 & 0 & 0 & 0 & 0 & 0 & 0 & 0 & 0 & 0 & .01 & 0 \\
\hline 29 & 0 & 0 & 0 & 0 & ---- & 0 & 0 & 0 & $0^{*}$ & $1.3^{*}$ & 0 & 0 \\
\hline 30 & 0 & 0 & 0 & 0 & ----- & 0 & 0 & 0 & $0^{*}$ & 0 & 0 & 0 \\
\hline 31 & 0 & ----- & 0 & 0 & & 0 & ----- & 0 & ------ & 0 & 0 & ------ \\
\hline Total & 0.29 & 0 & 0 & 0 & 0 & 0 & 0 & 0 & 1.3 & 6.42 & 35.18 & 0.45 \\
\hline Mean & .009 & 0 & 0 & 0 & 0 & 0 & 0 & 0 & .043 & .21 & 1.13 & .015 \\
\hline $\operatorname{Max}$ & .29 & 0 & 0 & 0 & 0 & 0 & 0 & 0 & 1.3 & 3.4 & 12 & .45 \\
\hline Min & 0 & 0 & 0 & 0 & 0 & 0 & 0 & 0 & 0 & 0 & 0 & 0 \\
\hline Acre-Ft & .58 & 0 & 0 & 0 & 0 & 0 & 0 & 0 & 2.6 & 13 & 70 & .89 \\
\hline Wtr Year & 2006 & Total & 43.6 & & Mean & .12 & Max & 12 & Min & 0 & Acre-Ft & 87 \\
\hline Cal Year & 2005 & Total & 435.77 & & Mean & .19 & Max & 16 & Min & 0 & Acre-Ft & 864 \\
\hline
\end{tabular}




\section{E050 Los Alamos Canyon below LA Weir}

Location. Lat. 35 52'71.02", long. 106 $13^{\circ} .03^{\prime \prime}$, Easting 1650066.300, Northing 1770912.00, SE 1/4, NE 1/4, sec. 20, T. 19N, R. 7E, on right bank, $200 \mathrm{ft}$ downstream from Los Alamos Weir, beside SR 4, 2.7 miles northwest of White Rock, New Mexico.

Drainage Area. $10.42 \mathrm{mi}^{2}$.

Period of Record. May 2001 to September 30, 2006.

Revised Record. Drainage Area (this report).

Gage. Data logger with cellular telemetry. Elevation of gage is $6,345 \mathrm{ft}$ above NGVD from GIS 9.1.

Remarks. Water discharge records good, except for estimated daily discharges, which are fair. Flows regulated by broad-crested weir $200 \mathrm{ft}$ upstream.

Extremes for Period of Record. Maximum discharge $252 \mathrm{ft}^{3} / \mathrm{s}$ August 8, 2006, gage height $3.20 \mathrm{ft}$. (from slope area measurement). No flow most of time.

Extremes for Current Year. Maximum discharge $252 \mathrm{ft}^{3} / \mathrm{s}$ at $1340 \mathrm{~h}$, August 8, gage height $3.20 \mathrm{ft}$. (from slope area measurement). No flow most of time.

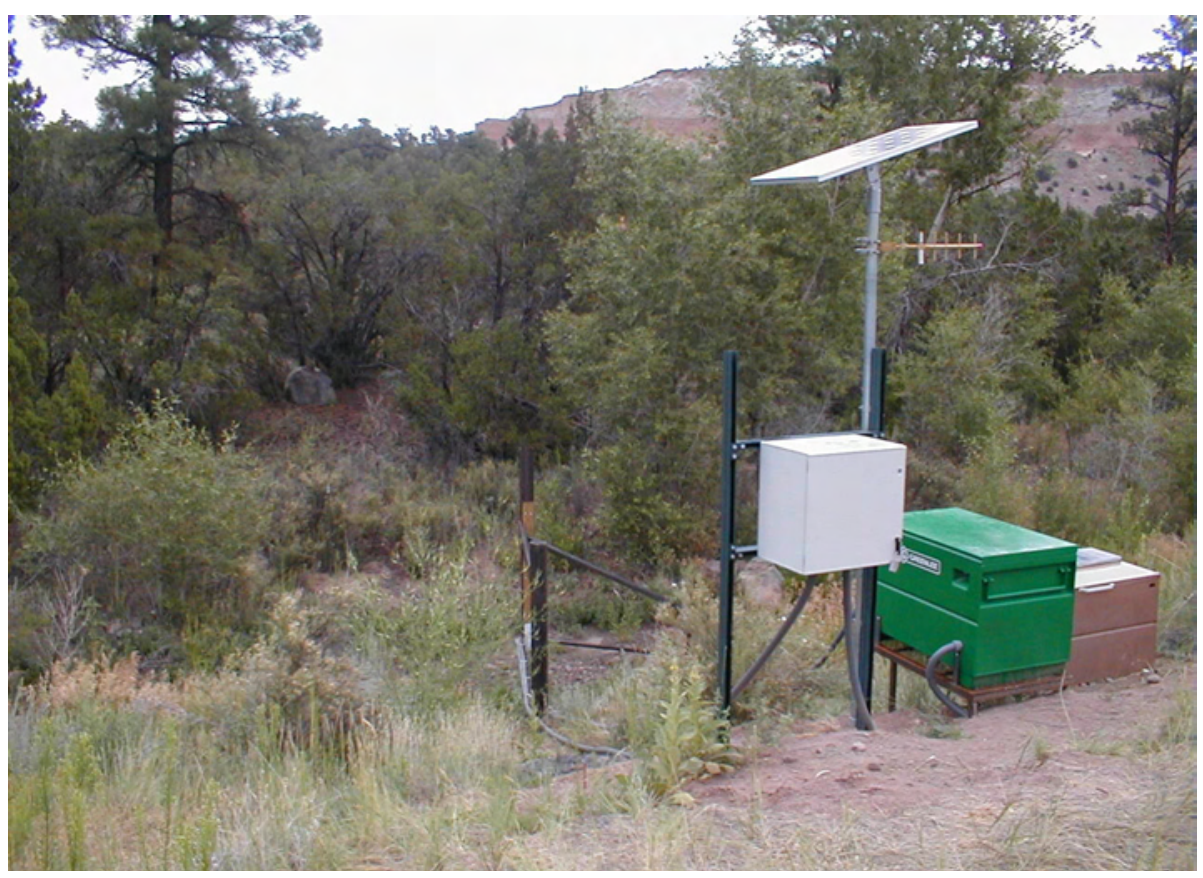




\section{E050 Los Alamos Canyon below LA Weir \\ Station Analysis \\ 2006 Water Year}

Equipment. Sutron 8210 data logger (5-min. interval) with cellular phone and speech modem housed in a NEMA shelter on left bank. Bubble gage is sensing device and outside staff is reference gage. A ISCO brand automatic sampler is stage-triggered by the data logger. No provision for direct measurement of flows above wading stage.

Field Work. The station was visited twenty-six times for the purpose of making a discharge measurement and/or servicing the instrumentation. Field inspections for the gage are listed under site history files on the Hydstra database. Discharge measurements for the gage are listed under site gauging files on the Hydstra database.

Datum Correction. None. Levels of May 31, 2001, found gage within limits no correction needed.

Gage-Height Record. The data logger referenced to the outside staff gave a complete and satisfactory record except for the following date: October 1-11 and February 15 to March 2 when gage height record lost due to power failure.

Rating. The channel is straight for 100 feet upstream and downstream. Bed is large gravel and well armored and should not be subject to much movement. Channel is trapezoidal with little or no vegetation. Flow is regulated somewhat by detention weir just upstream.

Rating No. 1 was developed based on all the measurements made during the period of record. Shifts are small and variable. Flows are very flashy, less than one hour, so mean daily discharge are very small relation to the instantaneous peak.

Three discharge measurements (No. 20-21) and twenty-six inspections of no flow were made during the year. No. 21 is slope area measurement of peak flow.

Discharge. Discharge was computed from Rating No. 1 with shifts applied by stage diagram. Periods of lost record are estimated using station E042.

Remarks. Records good except for estimated daily discharges, which are fair. 


\section{E050 Los Alamos Canyon below LA Weir}

Daily Mean Discharge in Cubic Feet per Second

Water Year October 2005 to September 2006

\begin{tabular}{|c|c|c|c|c|c|c|c|c|c|c|c|c|}
\hline DAY & OCT & NOV & DEC & JAN & FEB & MAR & APR & MAY & JUN & JUL & AUG & SEP \\
\hline 1 & $0^{*}$ & 0 & 0 & 0 & 0 & $0^{*}$ & 0 & 0 & 0 & 0 & .88 & 0 \\
\hline 2 & $0^{*}$ & 0 & 0 & 0 & 0 & $0^{*}$ & 0 & 0 & 0 & 0 & 0 & 0 \\
\hline 3 & $0^{*}$ & 0 & 0 & 0 & 0 & 0 & 0 & 0 & 0 & .01 & 0 & 0 \\
\hline 4 & $0^{*}$ & 0 & 0 & 0 & 0 & 0 & 0 & 0 & 0 & .13 & 0 & 0 \\
\hline 5 & $0^{*}$ & 0 & 0 & 0 & 0 & 0 & 0 & 0 & 0 & 3.7 & .22 & 0 \\
\hline 6 & $0^{*}$ & 0 & 0 & 0 & 0 & 0 & 0 & 0 & 0 & .02 & .06 & 0 \\
\hline 7 & $0^{*}$ & 0 & 0 & 0 & 0 & 0 & 0 & 0 & 0 & 0 & 2.5 & 0 \\
\hline 8 & $0^{*}$ & 0 & 0 & 0 & 0 & 0 & 0 & 0 & 0 & 0 & 9.2 & 0 \\
\hline 9 & $.01^{*}$ & 0 & 0 & 0 & 0 & 0 & 0 & 0 & 0 & 1.4 & .22 & 0 \\
\hline 10 & $0^{*}$ & 0 & 0 & 0 & 0 & 0 & 0 & 0 & 0 & 0 & .02 & 0 \\
\hline 11 & $0^{*}$ & 0 & 0 & 0 & 0 & 0 & 0 & 0 & 0 & 0 & 0 & .04 \\
\hline 12 & 0 & 0 & 0 & 0 & 0 & 0 & 0 & 0 & 0 & 0 & .02 & 0 \\
\hline 13 & 0 & 0 & 0 & 0 & 0 & 0 & 0 & 0 & 0 & 0 & 0 & 0 \\
\hline 14 & 0 & 0 & 0 & 0 & 0 & 0 & 0 & 0 & 0 & 0 & 0 & 0 \\
\hline 15 & .01 & 0 & 0 & 0 & $0^{*}$ & 0 & 0 & 0 & 0 & 0 & .13 & 0 \\
\hline 16 & .03 & 0 & 0 & 0 & $0^{*}$ & 0 & 0 & 0 & 0 & 0 & 0 & 0 \\
\hline 17 & 0 & 0 & 0 & 0 & $0^{*}$ & 0 & 0 & 0 & 0 & 0 & 0 & 0 \\
\hline 18 & 0 & 0 & 0 & 0 & $0^{*}$ & 0 & 0 & 0 & 0 & 0 & 0 & 0 \\
\hline 19 & .27 & 0 & 0 & 0 & $0^{*}$ & 0 & 0 & 0 & 0 & 0 & .09 & .03 \\
\hline 20 & 0 & 0 & 0 & 0 & $0^{*}$ & 0 & 0 & 0 & 0 & 0 & 0 & 0 \\
\hline 21 & 0 & 0 & 0 & 0 & $0^{*}$ & 0 & 0 & 0 & 0 & 0 & .08 & 0 \\
\hline 22 & 0 & 0 & 0 & 0 & $0^{*}$ & 0 & 0 & 0 & 0 & 0 & 0 & 0 \\
\hline 23 & 0 & 0 & 0 & 0 & $0^{*}$ & 0 & 0 & 0 & 0 & 0 & 0 & 0 \\
\hline 24 & 0 & 0 & 0 & 0 & $0^{*}$ & 0 & 0 & 0 & 0 & 0 & 0 & 0 \\
\hline 25 & 0 & 0 & 0 & 0 & $0^{*}$ & 0 & 0 & 0 & 0 & 0 & 4.9 & 0 \\
\hline 26 & 0 & 0 & 0 & 0 & $0^{*}$ & 0 & 0 & 0 & 0 & .01 & .16 & 0 \\
\hline 27 & 0 & 0 & 0 & 0 & $0^{*}$ & 0 & 0 & 0 & 0 & 0 & 0 & 0 \\
\hline 28 & 0 & 0 & 0 & 0 & $0^{*}$ & 0 & 0 & 0 & 0 & 0 & 0 & 0 \\
\hline 29 & 0 & 0 & 0 & 0 & ------ & 0 & 0 & 0 & 1.4 & 0 & 0 & 0 \\
\hline 30 & 0 & 0 & 0 & 0 & ---- & 0 & 0 & 0 & .04 & 0 & 0 & 0 \\
\hline 31 & 0 & ----- & 0 & 0 & ---- & 0 & ----- & 0 & ----- & 0 & 0 & ------ \\
\hline Total & 0.32 & 0 & 0 & 0 & 0 & 0 & 0 & 0 & 1.44 & 5.27 & 18.48 & 0.07 \\
\hline Mean & .010 & 0 & 0 & 0 & 0 & 0 & 0 & 0 & .048 & .17 & .60 & .002 \\
\hline Max & .27 & 0 & 0 & 0 & 0 & 0 & 0 & 0 & 1.4 & 3.7 & 9.2 & .04 \\
\hline Min & 0 & 0 & 0 & 0 & 0 & 0 & 0 & 0 & 0 & 0 & 0 & 0 \\
\hline Acre-Ft & .63 & 0 & 0 & 0 & 0 & 0 & 0 & 0 & 2.9 & 10 & 37 & .14 \\
\hline Wtr Year & 2006 & Total & & & Mean & .070 & Max & 9.2 & Min & 0 & Acre-Ft & 51 \\
\hline Cal Year & 2005 & Total & & & Mean & .05 & Max & 8.4 & Min & 0 & Acre-Ft & 757 \\
\hline
\end{tabular}




\section{E055 Pueblo above Acid}

Location. Lat. $35^{\circ} 53^{\prime} 20^{\prime \prime}$, long. $106^{\circ} 18^{\prime} 14^{\prime \prime}$, on left bank, $100 \mathrm{ft}$ above mouth of Acid Canyon, NE 1/4, SW 1/4, Sec. 9, T 19 N, R 6 E, Los Alamos County, 0.75 mile. downstream from Diamond Drive and 1.0 mile south of Los Alamos County Golf Course.

Drainage Area. $3.42 \mathrm{mi}^{2}$.

Period of Record. October 1, 2002, to September 30, 2006.

Gage. Data logger with cellular telemetry. Elevation of gage is $6,945 \mathrm{ft}$. above NGVD from GIS 9.1.

Remarks. Water discharge records fair to poor.

Extremes Outside Period of Record. Maximum discharge 1,600 $\mathrm{ft}^{3} / \mathrm{s}$ (from slope-area computation), July 2, 2001, gage height $7.3 \mathrm{ft}$ (from flood mark). No flows most of time.

Extremes for Period of Record. Maximum discharge 1,780 $\mathrm{ft}^{3} / \mathrm{s}$, August 8, gage height $7.50 \mathrm{ft}$ (from critical depth computation). No flow most of time.

Extremes for Current Year. Maximum discharge 1,780 $\mathrm{ft}^{3} / \mathrm{s}$, at $1220 \mathrm{~h}$, August 8, gage height $7.50 \mathrm{ft}$ (from critical depth computation). No flow most of time.

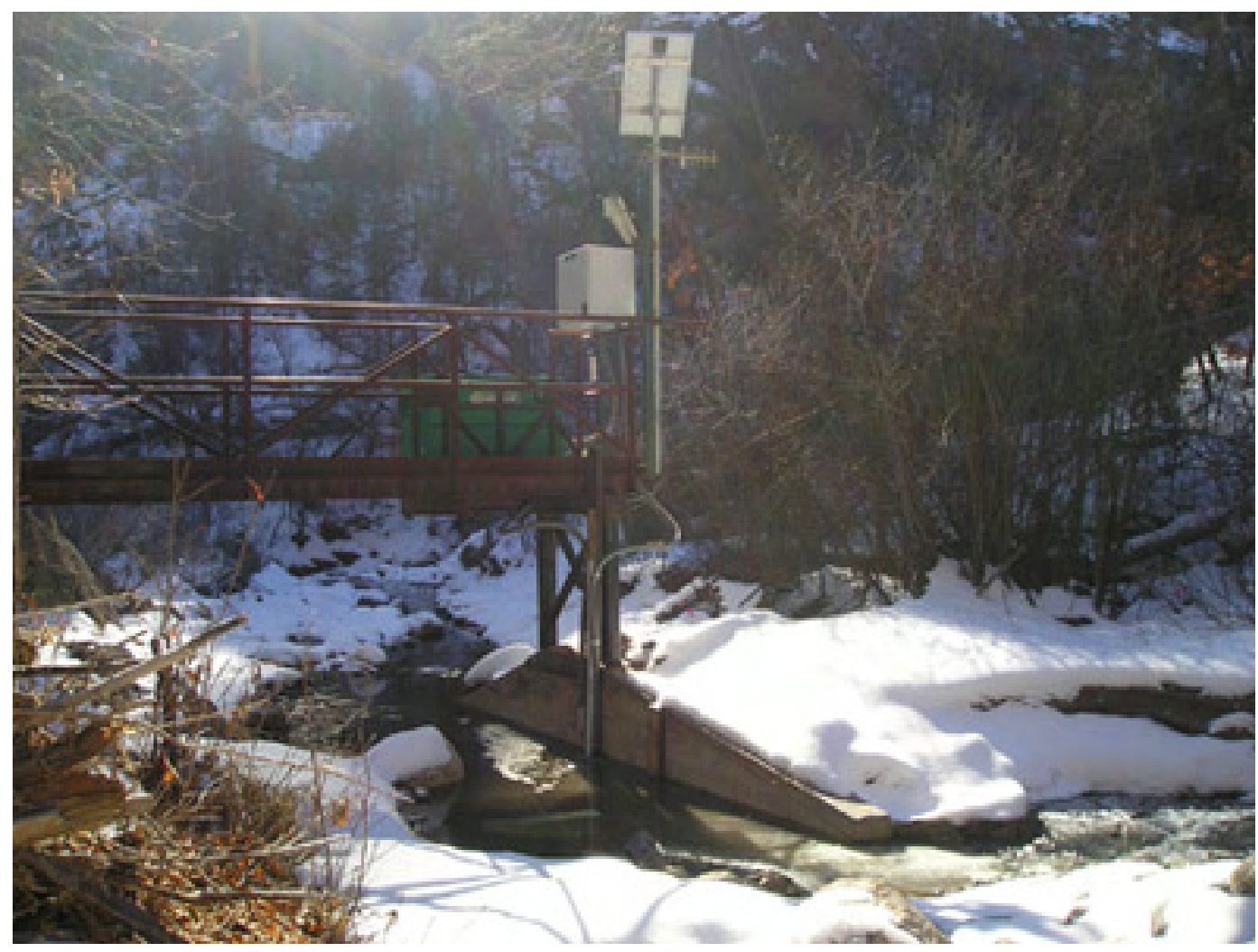




\section{E055 Pueblo above Acid \\ Station Analysis \\ 2006 Water Year}

Equipment. Sutron 8210 data logger (5-min. interval) with cellular phone and speech modem housed in a NEMA shelter on right bank with Sutron bubble gage as stage sensor. ISCO brand samplers are housed in a separate shelter and triggered by the data logger at certain stage. No provision for direct discharge measurements above wading stage.

Field Work. The station was visited twenty-five times for the purpose of making a discharge measurement and/or servicing the instrumentation. Field inspections for the gage are listed under site history files on the Hydstra database. Discharge measurements for the gage are listed under site gauging files on the Hydstra database.

\section{Datum Correction. None.}

Gage-Height Record. Record was complete for year.

Rating. Channel come into gage from a left-to-right bend and bends hard left about 100 feet below gage. Bed is unstable sand and gravel with some boulders. The left bank downstream from gage is heavily wooded, which tends to hold the flow to the right out the of the gage reach. Lower end of any stage-discharge relation here will be unstable. The upper end could be stable, but floods and construction have enabled the flow to jump channel at the bend above the gage and allow significant flow to go down the road not in accordance with recorded gage heights. This jump-out occurs at about $500 \mathrm{cfs}$. This channel problem was corrected in March of this year.

Rating No. 1 was developed using a slope area computation of about 1,400 cfs, one critical depth of $850 \mathrm{cfs}$ and various low flow measurements (No. 1-11) low water definition is poor and high end needs to be confirmed. At the time of this analysis Rating No. 1 is fair.

Five discharge measurements (No. 20-24) were made this year. They covered a small range of discharge.

Discharge. Discharge was computed using Rating No. 1 and series of "V" diagrams with some rather erratic shift patterns. High flow where computed direct. Several days listed as "estimated on 9-211, but that was because fill conditions in channel did not allow rating to computed zero flow.

Critical depth computation was made on flood of August 8. It yielded 1,400 cfs, which was about $0.5 \mathrm{ft}$ left of Rating No. 1. Computation was to the rating which yielded about 1,750 cfs at the peak.

Remarks. Records fair to poor. 


\section{E055 Pueblo above Acid}

Daily Mean Discharge in Cubic Feet per Second

Water Year October 2005 to September 2006

\begin{tabular}{|c|c|c|c|c|c|c|c|c|c|c|c|c|}
\hline DAY & OCT & NOV & DEC & JAN & FEB & MAR & APR & MAY & JUN & JUL & AUG & SEP \\
\hline 1 & .26 & .13 & 0 & 0 & 0 & 0 & 0 & 0 & 0 & 0 & .54 & .21 \\
\hline 2 & .20 & .19 & 0 & 0 & 0 & 0 & 0 & 0 & 0 & 0 & .18 & .19 \\
\hline 3 & .16 & .05 & 0 & 0 & 0 & 0 & 0 & 0 & 0 & 0 & .11 & .17 \\
\hline 4 & .16 & .01 & 0 & 0 & 0 & 0 & 0 & 0 & 0 & 0 & .08 & .16 \\
\hline 5 & .13 & 0 & 0 & 0 & 0 & 0 & 0 & 0 & 0 & .15 & .31 & .14 \\
\hline 6 & .12 & 0 & 0 & 0 & 0 & 0 & 0 & 0 & 0 & .29 & .17 & .17 \\
\hline 7 & .11 & 0 & 0 & 0 & 0 & 0 & 0 & 0 & 0 & .12 & .61 & .20 \\
\hline 8 & .10 & 0 & 0 & 0 & 0 & 0 & 0 & 0 & 0 & .13 & 35 & .19 \\
\hline 9 & .22 & 0 & 0 & 0 & 0 & 0 & 0 & 0 & 0 & .22 & 1.9 & .16 \\
\hline 10 & .25 & 0 & 0 & 0 & 0 & 0 & 0 & 0 & 0 & .24 & 2.2 & .17 \\
\hline 11 & .18 & 0 & 0 & 0 & 0 & 0 & 0 & 0 & 0 & .20 & 1.7 & .19 \\
\hline 12 & .13 & 0 & 0 & 0 & 0 & 0 & 0 & 0 & 0 & .19 & 1.4 & .17 \\
\hline 13 & .10 & 0 & 0 & 0 & 0 & 0 & 0 & 0 & 0 & .11 & 1.3 & .10 \\
\hline 14 & .08 & 0 & 0 & 0 & 0 & 0 & 0 & 0 & 0 & .06 & 1.3 & .05 \\
\hline 15 & .15 & 0 & 0 & 0 & 0 & 0 & 0 & 0 & 0 & .02 & 1.5 & 0 \\
\hline 16 & .15 & 0 & 0 & 0 & 0 & 0 & 0 & 0 & 0 & 0 & 1.1 & 0 \\
\hline 17 & .10 & 0 & 0 & 0 & 0 & 0 & 0 & 0 & 0 & 0 & 1.2 & 0 \\
\hline 18 & .13 & 0 & 0 & 0 & 0 & 0 & 0 & 0 & 0 & 0 & 1.0 & 0 \\
\hline 19 & .21 & 0 & 0 & 0 & 0 & 0 & 0 & 0 & 0 & 0 & 1.5 & 0 \\
\hline 20 & .13 & 0 & 0 & 0 & 0 & 0 & 0 & 0 & 0 & 0 & . 36 & 0 \\
\hline 21 & .08 & 0 & 0 & 0 & 0 & 0 & 0 & 0 & 0 & 0 & .34 & 0 \\
\hline 22 & .07 & 0 & 0 & 0 & 0 & 0 & 0 & 0 & 0 & 0 & .30 & 0 \\
\hline 23 & .06 & 0 & 0 & 0 & 0 & 0 & 0 & 0 & 0 & 0 & .29 & 0 \\
\hline 24 & .06 & 0 & 0 & 0 & 0 & 0 & 0 & 0 & 0 & 0 & .28 & 0 \\
\hline 25 & .06 & 0 & 0 & 0 & 0 & 0 & 0 & 0 & 0 & 0 & 1.3 & 0 \\
\hline 26 & .07 & 0 & 0 & 0 & 0 & 0 & 0 & 0 & 0 & 0 & .27 & 0 \\
\hline 27 & .06 & 0 & 0 & 0 & 0 & 0 & 0 & 0 & 0 & 0 & .17 & 0 \\
\hline 28 & .06 & 0 & 0 & 0 & 0 & 0 & 0 & 0 & 0 & 0 & .15 & 0 \\
\hline 29 & .05 & 0 & 0 & 0 & ----- & 0 & 0 & 0 & 0 & 0 & .14 & 0 \\
\hline 30 & .04 & 0 & 0 & 0 & ----- & 0 & 0 & 0 & 0 & 0 & .20 & 0 \\
\hline 31 & .04 & ----- & 0 & 0 & ---- & 0 & ----- & 0 & ----- & .15 & .22 & ---- \\
\hline Total & 3.72 & 0.38 & 0 & 0 & 0 & 0 & 0 & 0 & 0 & 1.88 & 57.12 & 2.27 \\
\hline Mean & .12 & .013 & 0 & 0 & 0 & 0 & 0 & 0 & 0 & .061 & 1.84 & .076 \\
\hline Max & .26 & .19 & 0 & 0 & 0 & 0 & 0 & 0 & 0 & .29 & 35 & .21 \\
\hline Min & .04 & 0 & 0 & 0 & 0 & 0 & 0 & 0 & 0 & 0 & .08 & 0 \\
\hline Acre-Ft & 7.4 & .75 & 0 & 0 & 0 & 0 & 0 & 0 & 0 & 3.7 & 113 & 4.5 \\
\hline Wtr Year & \multicolumn{2}{|c|}{2006} & Total & 65.37 & Mean & .18 & Max & 35 & Min & 0 & Acre-Ft & 130 \\
\hline Cal Year & \multicolumn{2}{|c|}{2005} & Total & 217.72 & Mean & .60 & Max & 6.9 & Min & 0 & Acre-Ft & 432 \\
\hline
\end{tabular}




\section{E0555 South Fork Acid Canyon}

Location. Lat. 3553'10", long. 106¹8'26"SE 1/4, SW 1/4, Sec. 9, T 19 N, R 6 E, Los Alamos County, on left bank, 0.6 mile. NW of county swimming pool, 1.2 miles from junction of Diamond Drive and Canyon Road.

Drainage Area. $0.08 \mathrm{mi}^{2}$.

Period of Record. August 18, 2002, to September 30, 2006.

Gage. Data logger with cellular telemetry. Elevation of gage is 7,100.4 ft. above NGVD from GIS 9.1.

Remarks. Water discharge records good.

Extremes for Period of Record. Maximum discharge $108 \mathrm{ft}^{3} / \mathrm{s}$, August 8, 2006, gage height $6.22 \mathrm{ft}$. (from critical depth computation). No flow most of time.

Extremes for Current Year. Maximum discharge $108 \mathrm{ft}^{3} / \mathrm{s}$, at $1200 \mathrm{~h}$, August 8, gage height $6.22 \mathrm{ft}$ (from critical depth computation). No flow most of time.

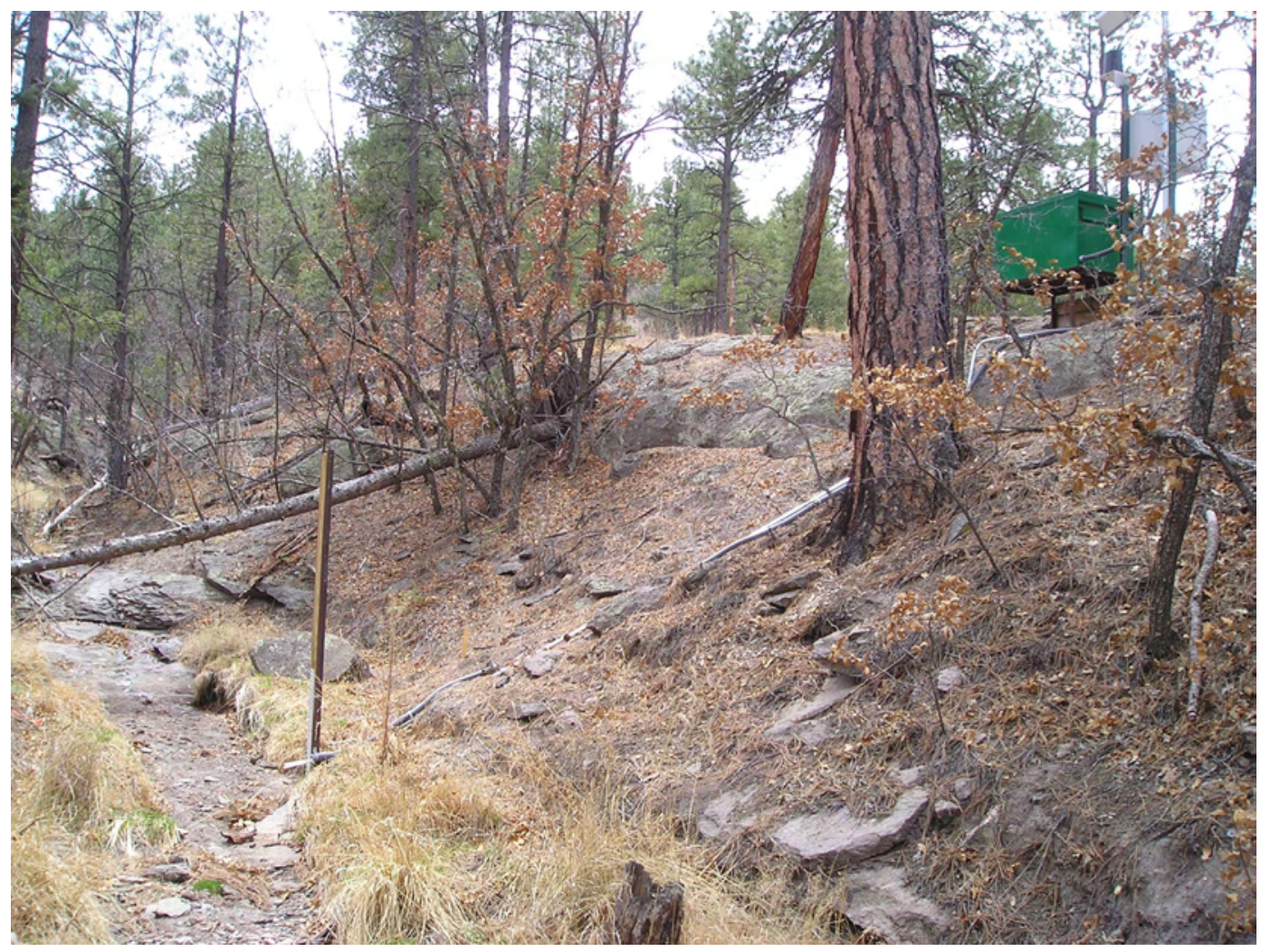




\section{E055 South Fork Acid Canyon \\ Station Analysis \\ 2006 Water Year}

Equipment. Sutron 8210 data logger (5-min. interval) with a Sutron shaft encoder and cellular phone with speech modem housed in a NEMA shelter on left bank. The system is powered by a solar panel battery system. The station is also equipped with a pair of ISCO pump samplers for water quality sample collection. Samples are triggered by stage through the data logger. An outside staff gage is available for reference. No provision for discharge measurements above wading stage. All high measurement will be by slope area or peak flow computation methods.

Field Work. The station was visited nineteen times for the purpose of making a discharge measurement and/or servicing the instrumentation. Field inspections for the gage are listed under site history files on the Hydstra database. Discharge measurements for the gage are listed under site gauging files on the Hydstra database.

Datum Correction. None. Level of November 8, 2005, found gage within limits. No corrections needed.

Gage-Height Record. The data logger referenced to the outside staff gave a complete and satisfactory record for the period of record, except for June 20 to July 5 when data logger malfunctioned.

Rating. The channel is straight for about 75 feet upstream and 100 feet downstream. The channel is trapezoidal with little vegetation. Bed is rock with gravel and should not be subject to very much movement.

Rating No. 1 was developed by one discharge measurement of low flow and one slope area measurement of peak flow. Rating curve was extended to 6.22 based on a critical depth computation.

One discharge measurement was made (No. 3). Number 3 being a measurement, with nineteen inspections of no flow.

Discharge. Discharge was computed by applying Rating No. 1 direct with zero shifts applied.

Period of no gage height record worked to high water marks on strip chart.

Remarks. Records good. 


\section{E0555 South Fork Acid Canyon}

Daily Mean Discharge in Cubic Feet per Second

Water Year October 2005 to September 2006

\begin{tabular}{|c|c|c|c|c|c|c|c|c|c|c|c|c|}
\hline DAY & OCT & NOV & DEC & JAN & FEB & MAR & APR & MAY & JUN & JUL & AUG & SEP \\
\hline 1 & 0 & 0 & 0 & 0 & 0 & 0 & 0 & 0 & 0 & $.21^{*}$ & 1.4 & . 10 \\
\hline 2 & 0 & 0 & 0 & 0 & 0 & 0 & 0 & 0 & 0 & $1.6^{*}$ & .96 & .59 \\
\hline 3 & 0 & 0 & 0 & 0 & 0 & 0 & 0 & 0 & 0 & $3.0^{*}$ & .27 & .01 \\
\hline 4 & 0 & 0 & 0 & 0 & 0 & 0 & 0 & 0 & 0 & $.49^{*}$ & 1.2 & 0 \\
\hline 5 & 0 & 0 & 0 & 0 & 0 & 0 & 0 & 0 & 0 & $1.6^{*}$ & 1.7 & 0 \\
\hline 6 & 0 & 0 & 0 & 0 & 0 & 0 & 0 & 0 & 0 & .73 & 1.1 & .30 \\
\hline 7 & 0 & 0 & 0 & 0 & 0 & 0 & 0 & 0 & 0 & .21 & 2.3 & .62 \\
\hline 8 & 0 & 0 & 0 & 0 & 0 & 0 & 0 & 0 & 0 & .11 & 3.8 & .49 \\
\hline 9 & .04 & 0 & 0 & 0 & 0 & 0 & 0 & 0 & 0 & .21 & 1.1 & .20 \\
\hline 10 & .01 & 0 & 0 & 0 & 0 & 0 & 0 & 0 & 0 & .05 & .79 & .18 \\
\hline 11 & 0 & 0 & 0 & 0 & 0 & 0 & 0 & 0 & 0 & .01 & .33 & .48 \\
\hline 12 & 0 & 0 & 0 & 0 & 0 & 0 & 0 & 0 & 0 & 0 & .45 & .10 \\
\hline 13 & 0 & 0 & 0 & 0 & 0 & 0 & 0 & 0 & 0 & 0 & .65 & .02 \\
\hline 14 & 0 & 0 & 0 & 0 & 0 & 0 & 0 & 0 & 0 & 0 & .80 & 0 \\
\hline 15 & .01 & 0 & 0 & 0 & 0 & 0 & 0 & 0 & 0 & 0 & .91 & 0 \\
\hline 16 & 0 & 0 & 0 & 0 & 0 & 0 & 0 & 0 & 0 & 0 & .28 & .04 \\
\hline 17 & 0 & 0 & 0 & 0 & 0 & 0 & 0 & 0 & 0 & 0 & 0 & 0 \\
\hline 18 & .01 & 0 & 0 & 0 & 0 & 0 & 0 & 0 & 0 & 0 & 0 & 0 \\
\hline 19 & .03 & 0 & 0 & 0 & 0 & 0 & 0 & 0 & 0 & 0 & .46 & 0 \\
\hline 20 & 0 & 0 & 0 & 0 & 0 & 0 & 0 & 0 & $0^{*}$ & 0 & .59 & .03 \\
\hline 21 & 0 & 0 & 0 & 0 & 0 & 0 & 0 & 0 & $0^{*}$ & .01 & .47 & .04 \\
\hline 22 & 0 & 0 & 0 & 0 & 0 & 0 & 0 & 0 & $.01^{*}$ & .01 & .21 & .02 \\
\hline 23 & 0 & 0 & 0 & 0 & 0 & 0 & 0 & 0 & $0^{*}$ & 0 & 0 & 0 \\
\hline 24 & 0 & 0 & 0 & 0 & 0 & 0 & 0 & 0 & $0^{*}$ & 0 & 0 & 0 \\
\hline 25 & 0 & 0 & 0 & 0 & 0 & 0 & 0 & 0 & $0^{*}$ & 0 & 1.5 & 0 \\
\hline 26 & 0 & 0 & 0 & 0 & 0 & 0 & 0 & 0 & $0^{*}$ & .06 & .27 & 0 \\
\hline 27 & 0 & 0 & 0 & 0 & 0 & 0 & 0 & 0 & $0^{*}$ & .03 & .19 & 0 \\
\hline 28 & 0 & 0 & 0 & 0 & 0 & 0 & 0 & 0 & $0^{*}$ & .02 & .09 & 0 \\
\hline 29 & 0 & 0 & 0 & 0 & ----- & 0 & 0 & 0 & $0^{*}$ & 0 & 0 & 0 \\
\hline 30 & 0 & 0 & 0 & 0 & ----- & 0 & 0 & 0 & $.14^{*}$ & 0 & 0 & 0 \\
\hline 31 & 0 & ----- & 0 & 0 & ----- & 0 & ----- & 0 & ------ & 0 & 0 & ----- \\
\hline Total & 0.10 & 0 & 0 & 0 & 0 & 0 & 0 & 0 & 0.15 & 8.35 & 21.82 & 3.22 \\
\hline Mean & .003 & 0 & 0 & 0 & 0 & 0 & 0 & 0 & .005 & .27 & .70 & .11 \\
\hline Max & .04 & 0 & 0 & 0 & 0 & 0 & 0 & 0 & .14 & 3.0 & 3.8 & .62 \\
\hline Min & 0 & 0 & 0 & 0 & 0 & 0 & 0 & 0 & 0 & 0 & 0 & 0 \\
\hline Acre-Ft & .20 & 0 & 0 & 0 & 0 & 0 & 0 & 0 & .30 & 17 & 43 & 6.4 \\
\hline Wtr Year & 2006 & Total & 33.64 & Mean & .092 & & $\operatorname{Max}$ & .8 & Min & 0 & Acre-Ft & 67 \\
\hline Cal Year & 2005 & Total & 4.27 & Mean & .012 & & Max & .57 & Min & 0 & Acre-Ft & 8.5 \\
\hline
\end{tabular}




\section{E060 Pueblo above SR 502}

Location. Lat. 35'52'15", long. 106 $13^{\prime} 1 "$ ", in NE 1/4 sec. 20, T. 19 N, R. 7 E, Santa Fe County, on right bank, $100 \mathrm{yd}$ east of SR maintenance yard, $200 \mathrm{ft}$ north of SR 502, and 4.2 miles east of Los Alamos.

Drainage Area. $8.21 \mathrm{mi}^{2}$.

Period of Record. January 1992 to September 30, 2006.

Revised Record. Drainage Area (this report).

Gage. Data logger with cellular telemetry. Elevation of gage is $6,341 \mathrm{ft}$ above NGVD from GIS 9.1.

Remarks. Records fair. No diversion above station. Perennial flow is primarily from effluent.

Average Discharge. $12 \mathrm{yr}, 0.93 \mathrm{ft}^{3} / \mathrm{s}, 674$ acre-ft/yr.

Extremes for Period of Record. Maximum discharge 1,930 $\mathrm{ft}^{3} / \mathrm{s}$, August 8, 2006, gage height $11.75 \mathrm{ft}$ from slope-area measurement), from rating curve extended above $130 \mathrm{ft}^{3} / \mathrm{s}$ on basis of slope-area measurement. No flow at times.

Extremes for Current Water Year. Maximum discharge 1,930 $\mathrm{ft}^{3} / \mathrm{s}$ at $1430 \mathrm{~h}$, August 8, gage height $11.75 \mathrm{ft}$ (from slope-area measurement). No flow at times.

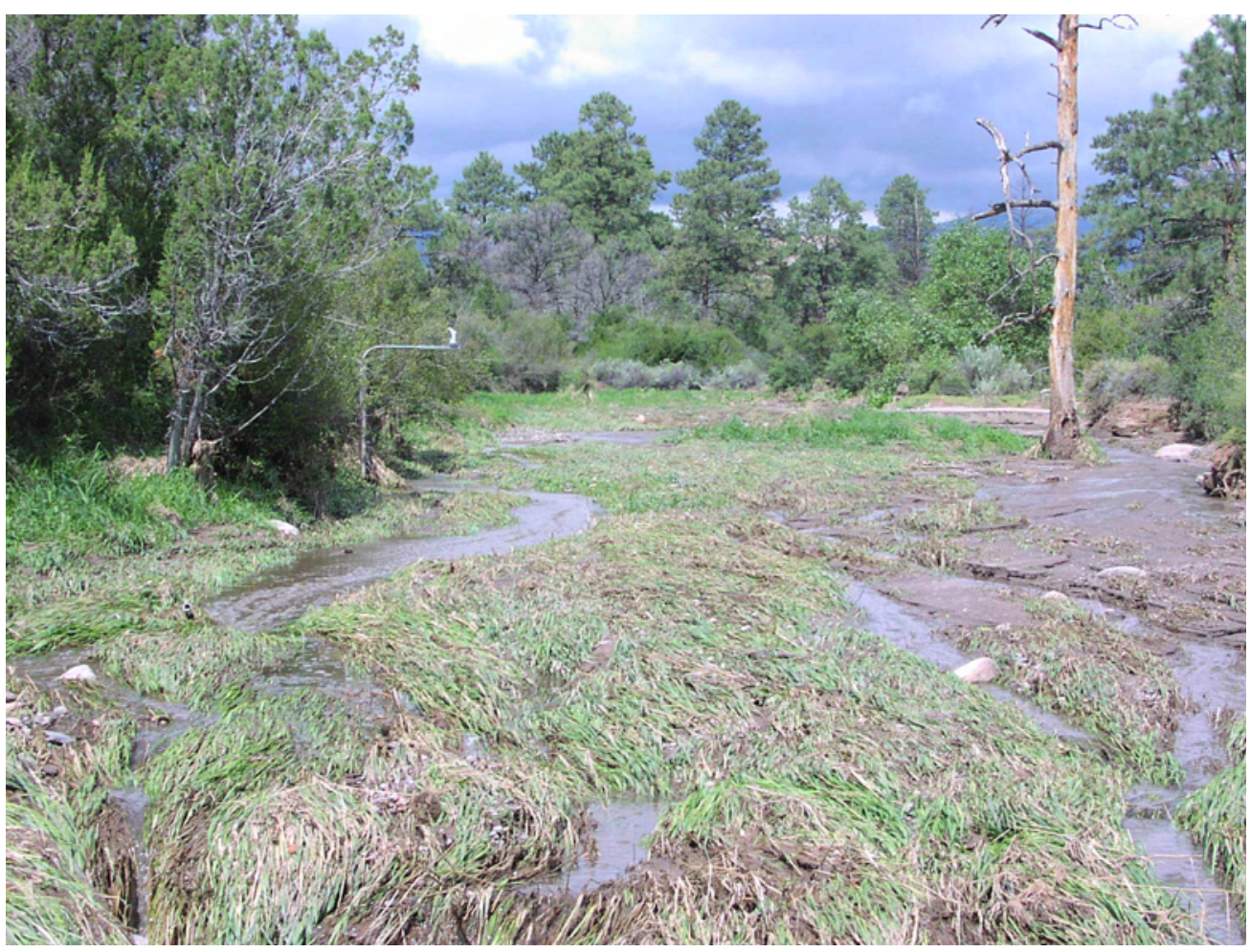




\section{E060 Pueblo above SR 502}

\section{Station Analysis}

2006 Water Year

Equipment. Sutron Accubar nonsubmersible transducer and 8210 data logger are housed in a $4^{\prime} \times 4^{\prime} \times 8^{\prime}$ metal shelter on right bank. A millitroncs sonic probe auxiliary stage sensor is mounted on top of a 4" $\times 4$ " steel channel that is used to support outside staff, and was installed June 1, 2006. The gaging station is also equipped with a pair of ISCO samplers for water quality data collection and are housed in a separate shelter in a $4^{\prime} \times 4^{\prime}$ metal box which is trigged by the data logger. An outside staff is available for reference gage. No provision for discharge measurements above wading stage.

Datum Correction. None

Gage-Height Record. Complete for the water year except for April 17-May 2 and May 24-29 when logger failed.

Rating. Channel is sand gravel/hard pan bed. Sand degrades easily and will change with flow events. Channel will be straight at high flow but is incised in sand and meandering at low flow.

Nine discharge measurements (No. 95-104) and twenty-three inspections were made during the year. Grasses become 4-5 feet tall and cause considerable backwater at most stages. These grasses usually get flattened by large peaks.

Rating No. 5 was continued in use. Shifts to the left .23-.90 are continuous and were confirmed by peak of record on August $8\left(1,930 \mathrm{ft}^{3} / \mathrm{s}\right)$. New rating will be drawn to begin new water year. The large peak caused more shifting to left with -.66 applied after flood. Minus .90 was applied on peak.

Discharge. Computed from rating 5 using V diagrams (all negative). Various ice days in January and February.

Remarks. Records fair. 


\section{E060 Pueblo above SR 502}

Daily Mean Discharge in Cubic Feet per Second

Water Year October 2005 to September 2006

\begin{tabular}{|c|c|c|c|c|c|c|c|c|c|c|c|c|}
\hline DAY & OCT & NOV & DEC & JAN & FEB & MAR & APR & MAY & JUN & JUL & AUG & SEP \\
\hline 1 & .37 & .59 & .46 & .44 & .62 & .70 & .22 & $.30^{*}$ & 0 & .20 & .58 & .50 \\
\hline 2 & .43 & .64 & .43 & .40 & .52 & .60 & .30 & $.30^{*}$ & 0 & .08 & .39 & .31 \\
\hline 3 & .51 & .55 & .41 & .43 & .69 & .55 & .25 & .27 & .06 & .21 & .15 & .39 \\
\hline 4 & .50 & .59 & .42 & .40 & .63 & .47 & .25 & .21 & .06 & .32 & .36 & .26 \\
\hline 5 & .50 & .71 & .42 & .44 & .60 & .50 & .22 & .16 & .05 & 5.1 & .08 & .32 \\
\hline 6 & .50 & .71 & .58 & .49 & .54 & .45 & .22 & .05 & 0 & .79 & .01 & .04 \\
\hline 7 & .48 & .65 & .42 & .50 & .51 & .19 & .28 & .18 & 0 & .41 & 17 & .56 \\
\hline 8 & .47 & .46 & .52 & .55 & .59 & .07 & .05 & .01 & .02 & .04 & 58 & 1.1 \\
\hline 9 & .49 & .61 & .64 & .25 & .47 & .03 & .31 & .14 & .03 & 3.2 & .08 & .86 \\
\hline 10 & .57 & .74 & .58 & .46 & .28 & .19 & .22 & 0 & .28 & .46 & 0 & .99 \\
\hline 11 & .57 & .68 & .44 & .88 & .81 & .27 & .22 & 0 & .09 & .45 & 0 & .93 \\
\hline 12 & .57 & .66 & .42 & .73 & .88 & .32 & .18 & .15 & .05 & .40 & 0 & .40 \\
\hline 13 & .56 & .71 & .40 & .93 & .63 & .18 & 0 & 0 & 0 & .16 & 0 & .32 \\
\hline 14 & .53 & .71 & .40 & .50 & .30 & .29 & .04 & 0 & 0 & .14 & .01 & .52 \\
\hline 15 & .57 & .75 & .47 & .50 & .66 & .12 & .33 & .12 & 0 & .18 & 0 & .65 \\
\hline 16 & .59 & .60 & .51 & .80 & .82 & .30 & .21 & .16 & 0 & .01 & 0 & .53 \\
\hline 17 & .60 & .62 & .51 & .48 & .80 & .33 & $.20^{*}$ & 0 & .02 & .07 & 0 & .81 \\
\hline 18 & .64 & .65 & .45 & .40 & .73 & .12 & $.15^{\star}$ & .03 & .07 & .01 & 0 & .49 \\
\hline 19 & .65 & .60 & .38 & .90 & .70 & .10 & $.15^{\star}$ & .20 & .06 & 0 & 0 & .38 \\
\hline 20 & .62 & .65 & .44 & .60 & .84 & .25 & $.12^{*}$ & .12 & 0 & .03 & 0 & .46 \\
\hline 21 & .60 & .60 & .59 & .60 & .70 & .30 & $.10^{*}$ & 0 & 0 & .17 & .01 & .31 \\
\hline 22 & .58 & .55 & .46 & .79 & .75 & .40 & $.10^{*}$ & .01 & 0 & .02 & 0 & .77 \\
\hline 23 & .61 & .55 & .46 & 1.5 & .80 & .38 & $.10^{*}$ & $.15^{*}$ & 0 & .09 & 0 & .61 \\
\hline 24 & .61 & .49 & .42 & 1.2 & 1.0 & .35 & $.15^{\star}$ & $0^{*}$ & 0 & .09 & 0 & .88 \\
\hline 25 & .62 & .49 & .41 & .94 & .60 & .38 & $.20^{*}$ & $0^{*}$ & 0 & .01 & 23 & .43 \\
\hline 26 & .48 & .45 & .40 & .90 & .55 & .38 & $.20^{*}$ & $0^{*}$ & .22 & .20 & 2.0 & .40 \\
\hline 27 & .61 & .50 & .41 & 1.1 & .50 & .26 & $.15^{\star}$ & $0^{*}$ & .16 & .08 & 1.5 & .39 \\
\hline 28 & .63 & .48 & .38 & .93 & .84 & .26 & $.10^{*}$ & $0^{*}$ & 0 & 0 & .70 & .42 \\
\hline 29 & .61 & .45 & .41 & .89 & ------ & .39 & $.12^{*}$ & $0^{*}$ & .20 & 0 & .60 & .42 \\
\hline 30 & .68 & .47 & .40 & .78 & ----- & .41 & $.20^{*}$ & $0^{*}$ & .23 & 0 & .50 & .38 \\
\hline 31 & .71 & ----- & .41 & .68 & ----- & .28 & ------ & $0^{*}$ & ------ & .04 & .50 & ----- \\
\hline Total & 17.46 & 17.91 & 14.05 & 21.39 & 18.36 & 9.82 & 5.34 & 2.56 & 1.60 & 12.96 & 105.47 & 15.83 \\
\hline Mean & .56 & .60 & .45 & .69 & .66 & .32 & .18 & .083 & .053 & .42 & 3.40 & .53 \\
\hline Max & .71 & .75 & .64 & 1.5 & 1.0 & .70 & .33 & .30 & .28 & 5.1 & 58 & 1.1 \\
\hline Min & .37 & .45 & .38 & .25 & .28 & .03 & 0 & 0 & 0 & 0 & 0 & .04 \\
\hline Acre-Ft & 35 & 36 & 28 & 42 & 36 & 19 & 11 & 5.1 & 3.2 & 26 & 209 & 31 \\
\hline Wtr Year & 2006 & Total & 242.75 & & & & Max & 58 & Min & 0 & Acre-Ft & 481 \\
\hline Cal Year & 2005 & Total & 199.02 & & & & Max & 8.0 & Min & 0 & Acre-Ft & 395 \\
\hline
\end{tabular}

* Estimated 


\section{E121 Sandia Right Fork at Power Plant}

Location. Lat. $35^{\circ} 52^{\prime} 31^{\prime \prime}$, long. $106^{\circ} 19^{\prime} 7^{\prime \prime}$, NW 1/4, SW 1/4, sec. 16, T. 19 N., R. 6 E., Los Alamos County, on left bank $300 \mathrm{ft}$ downstream from power plant, and 0.5 mile north of East Jemez Road.

Drainage Area. $0.08 \mathrm{mi}^{2}$.

Period of Record. June 6, 2002, to September 30, 2006.

Gage. Data logger with cellular telemetry. Elevation of gage is 7,283 ft above NGVD from GIS 9.1.

Remarks. Water discharge records good. Records for this site existed before this published period but are not reliable.

Extremes for Period of Record. Maximum discharge $191 \mathrm{ft}^{3} / \mathrm{s}$, June 21, 2002, from peak-flow computation, gage height $8.13 \mathrm{ft}$, minimum daily $0.17 \mathrm{ft}^{3} / \mathrm{s}$, December 9, 2003 .

Extremes for Current Year. Maximum discharge $61 \mathrm{ft}^{3} / \mathrm{s}$ at $1220 \mathrm{~h}$, August 8, gage height 7.23 ft., Minimum daily 0.26, May 6.

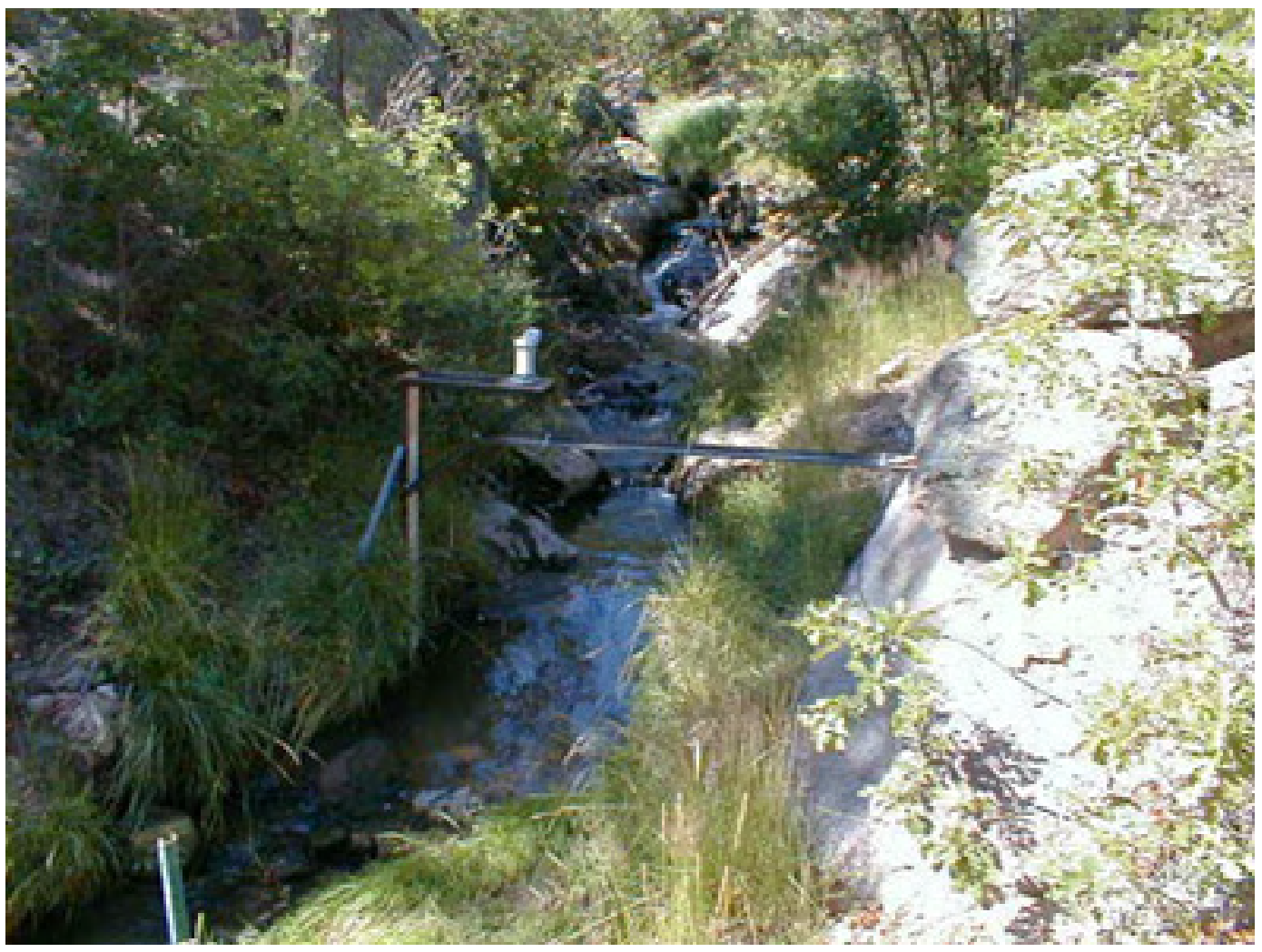




\section{E121 Sandia Canyon Right Fork at Power Plant}

Station Analysis

2006 Water Year

Equipment. Sutron 8210 data logger (5-min. interval) with cellular phone and speech modem housed in a NEMA shelter on left bank. The stage sensor is a Sutron Accubar nonsubmersible transducer. The gaging station is also equipped with two ISCO pump samplers for Water Quality collection in a $4^{\prime} \times 4^{\prime}$ metal box. An outside staff is available for reference. There is no provision for discharge measurement above wading stage.

Field Work. The station was visited twenty-one times for the purpose of making a discharge measurement and/or servicing the instrumentation. Field inspections for the gage are listed under site history files on the Hydstra database. Discharge measurements for the gage are listed under site gauging files on the Hydstra database.

\section{Datum Correction. None.}

Gage-Height Record. The data logger reference to the outside staff gave a complete and satisfactory record for the year except for October 1-5 when data logger malfunctioned.

Rating. The channel is straight for about 30 feet with a step upstream slope and straight for 50 feet downstream with a sharp slope downstream, The streambed through this reach is primarily sand, gravel, and cobbles more prevalent below the gage. The low-water control is a bedrock riffle below gage.

Twenty two discharge measurements (No. 24-46) measurement No. 47 was also used in this analysis and twenty one inspections during the water year. Discharge measurements were used to define a "V" diagram. Range in stage is fairly limited since most flow is effluent.

Rating No. 3 was developed based on measurements made during the period of record.

Discharge. Discharge was computed by applying Rating No. 3 with variable shifts defined by measurements and applied by "V" diagram. No shifts were applied to higher flows. There were no ice-affected discharges.

Remarks. Records good. 


\section{E121 Sandia Right Fork at Power Plant}

Daily Mean Discharge in Cubic Feet per Second

Water Year October 2005 to September 2006

\begin{tabular}{|c|c|c|c|c|c|c|c|c|c|c|c|c|}
\hline DAY & OCT & NOV & DEC & JAN & FEB & MAR & APR & MAY & JUN & JUL & AUG & SEP \\
\hline 1 & .68 & .58 & .53 & .63 & .63 & .49 & .72 & .40 & .31 & .54 & .66 & .81 \\
\hline 2 & .90 & .55 & .65 & .70 & .66 & .44 & .48 & .38 & .39 & .61 & .62 & .61 \\
\hline 3 & .80 & .47 & .61 & .67 & .73 & .59 & .74 & 0 & .31 & 1.1 & .71 & .58 \\
\hline 4 & .61 & .61 & .67 & .60 & .65 & .46 & .49 & .40 & .39 & .67 & .66 & .59 \\
\hline 5 & .65 & .49 & .77 & .81 & .64 & .60 & .64 & .61 & .40 & .88 & 1.2 & .65 \\
\hline 6 & .69 & .66 & .48 & .58 & .65 & .61 & .60 & .26 & .36 & .87 & .87 & .73 \\
\hline 7 & .74 & .65 & .54 & .59 & .69 & .39 & .65 & .35 & .48 & .64 & 2.1 & .57 \\
\hline 8 & .65 & .62 & .64 & .77 & .66 & .54 & .40 & .45 & .33 & .85 & 2.0 & .69 \\
\hline 9 & .99 & .65 & .56 & .77 & .82 & .59 & .57 & .46 & .39 & .78 & .39 & .59 \\
\hline 10 & .85 & .81 & .48 & .71 & .65 & .53 & .44 & .34 & .29 & .85 & .35 & .63 \\
\hline 11 & .73 & .75 & .50 & .64 & .71 & .65 & .59 & .62 & .45 & .60 & .26 & .73 \\
\hline 12 & .69 & .58 & .82 & .70 & .71 & .43 & .57 & .35 & .34 & .66 & .38 & .65 \\
\hline 13 & .62 & .60 & .45 & .55 & .84 & .52 & .51 & .39 & .33 & .65 & .34 & .62 \\
\hline 14 & .68 & .62 & .49 & .43 & .69 & .39 & .44 & .38 & .34 & .76 & .48 & .65 \\
\hline 15 & .86 & .63 & .88 & .45 & .58 & .50 & .48 & .46 & .40 & .71 & .39 & .62 \\
\hline 16 & .81 & .71 & .51 & .53 & 1.0 & .46 & .54 & .43 & .45 & .67 & .34 & .50 \\
\hline 17 & .66 & .76 & .53 & .57 & .60 & .57 & .41 & .53 & .36 & .64 & .27 & .52 \\
\hline 18 & .79 & .40 & .64 & .52 & .62 & .52 & .57 & .36 & .44 & .57 & .33 & .70 \\
\hline 19 & .82 & .67 & 1.1 & .32 & .58 & .72 & .47 & .44 & .32 & .69 & .76 & .55 \\
\hline 20 & .65 & .63 & .47 & .51 & .58 & .65 & .39 & .36 & .34 & .63 & .76 & .69 \\
\hline 21 & .72 & .77 & .69 & .47 & .57 & .52 & .43 & .43 & .38 & .73 & .59 & .63 \\
\hline 22 & .71 & .73 & .65 & .50 & .45 & .57 & .52 & .34 & .96 & .61 & .43 & .69 \\
\hline 23 & .85 & .54 & .45 & .70 & .42 & .63 & .38 & .33 & .47 & .57 & .44 & .53 \\
\hline 24 & .83 & .53 & .45 & .48 & .45 & .52 & .51 & .32 & .59 & .71 & .49 & .64 \\
\hline 25 & .87 & .52 & .64 & .62 & .45 & .55 & .46 & .34 & .57 & .55 & 3.2 & .60 \\
\hline 26 & .64 & .59 & .54 & .61 & .61 & .54 & .32 & .35 & .59 & .58 & .84 & .63 \\
\hline 27 & .71 & .64 & .57 & .55 & .52 & .75 & .50 & .30 & .48 & .60 & .64 & .54 \\
\hline 28 & .66 & .72 & .55 & .74 & .46 & .59 & .46 & .25 & .68 & .69 & .73 & .69 \\
\hline 29 & .58 & .43 & .56 & .56 & ----- & .58 & .43 & .29 & .61 & .56 & .75 & .56 \\
\hline 30 & .68 & .53 & .47 & .79 & ----ט & .64 & .45 & .35 & .55 & .59 & .69 & .59 \\
\hline 31 & .60 & ------- & .70 & .86 & ----- & .51 & ------ & .34 & -----ב- & .72 & .64 & -.-.- \\
\hline Total & 22.72 & 18.44 & 18.59 & 18.93 & 17.62 & 17.06 & 15.16 & 11.61 & 13.30 & 21.28 & 23.31 & 18.78 \\
\hline Mean & .73 & .61 & .60 & .61 & .63 & .55 & .51 & .37 & .44 & .69 & .75 & .63 \\
\hline Max & .99 & .81 & 1.1 & .86 & 1.0 & .75 & .74 & .62 & .96 & 1.1 & 3.2 & .81 \\
\hline Min & .58 & .40 & .45 & .32 & .42 & .39 & .32 & 0 & .29 & .54 & .26 & .50 \\
\hline Acre-Ft & 45 & .7 & 37 & 38 & 35 & 34 & 30 & 23 & 26 & 42 & 46 & 37 \\
\hline Wtr Year & 2006 & Tota & 216. & & & & Max & 3.2 & Min & 0 & Acre-Ft & 430 \\
\hline Cal Year & 2005 & Tota & 223. & & & & Max & 3.5 & Min & .24 & Acre-Ft & 443 \\
\hline
\end{tabular}

* Estimated 


\section{E1219 Sandia Canyon East of Power Plant}

Location. Lat. 35'52'30", long. 106 $19^{\prime} 10^{\prime \prime}$, Sec 16, R06E, T19N. Los Alamos County on right bank $150 \mathrm{ft}$ downstream of power plant and 0.3 mile north of east Jemez Road.

Drainage Area. $0.0024 \mathrm{mi}^{2}(1.54$ acres $)$.

Period of Record. March 3, 2006, to September 30, 2006

Gage. Data logger and 9" Parshall flume. Elevation of gage is 7,337 ft above NGVD from GIS 9.1.

Remarks. Water discharge records good.

Extremes for Period of Record. Maximum discharge, $3.1 \mathrm{ft}^{3} / \mathrm{s}$, August 25, 2005, gage height 1.01ft. No flow most of time.

Extremes for Current Year. Maximum discharge, $3.1 \mathrm{ft}^{3} / \mathrm{s}$ at $1215 \mathrm{~h}$, August 25, gage height $1.01 \mathrm{ft}$. No flow most of time.

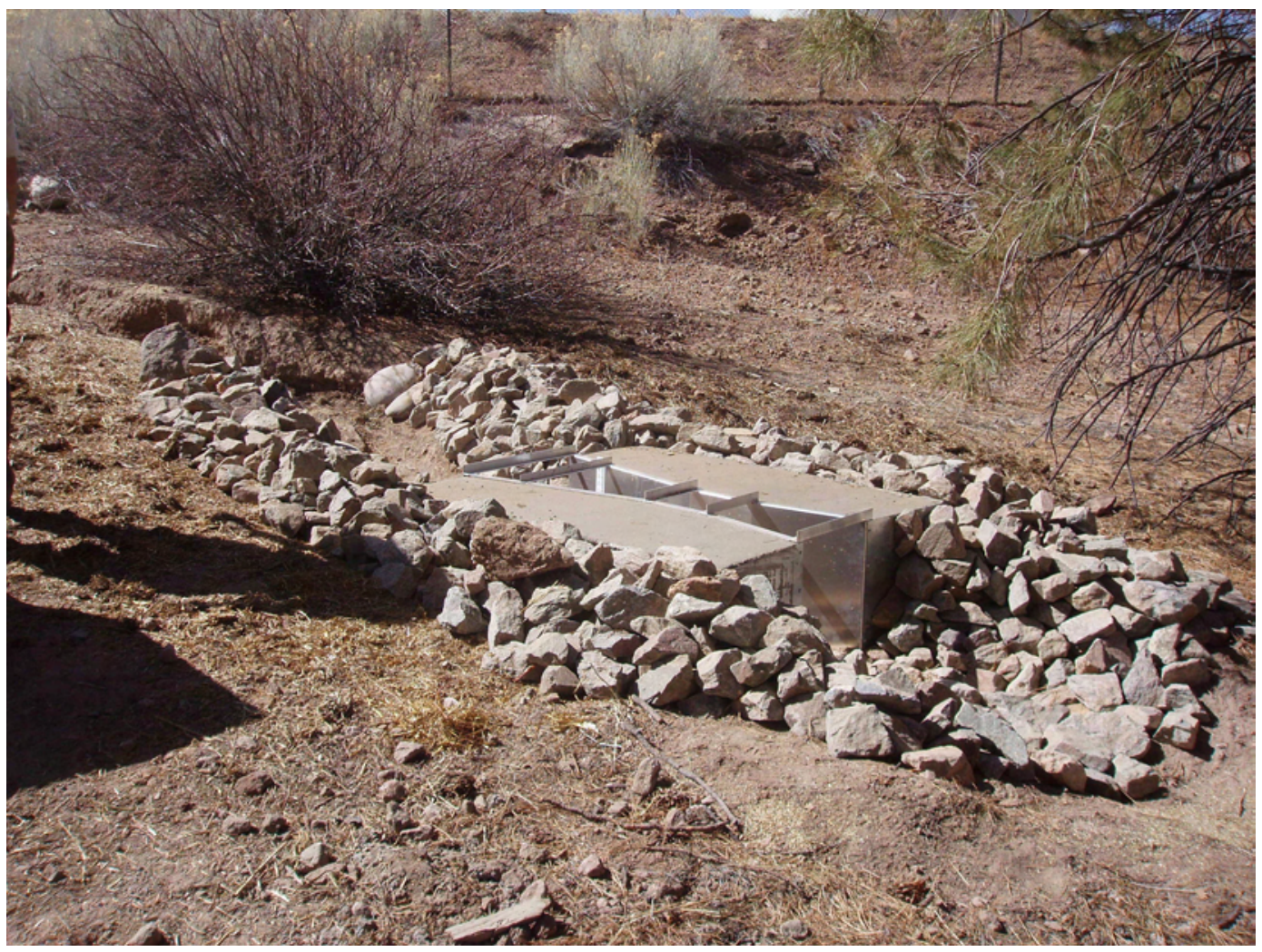




\section{E1219 Sandia Canyon East of Power Plant \\ Station Analysis \\ 2006 Water Year}

Equipment. Sutron 8210 data logger with a solar panel battery charging system is housed in a NEMA shelter on right bank. A milltronics sonic probe stage sensor is mounted on top a 9" Para shall flume. The gaging station is also equipped with an ISCO pump sampler for water quality data collection and is housed in a separate shelter $4^{\prime} \times 4^{\prime}$ metal box which is trigged by the data logger. The staff in the 9" Parshall flume is the reference gage. There is no provision for direct discharge measurements above wading stage.

Field Work. The station was visited sixteen times for the purpose of making a discharge measurement and/or servicing the instrumentation. Field inspections for the gage are listed under site history files on the Hydstra database. Discharge measurements for the gage are listed under site gauging files on the Hydstra database.

Datum Correction. None.

Gage-Height Record. The data logger referenced to the outside staff gave a complete and satisfactory for the year.

Rating. The channel is straight above and below gage. It is confined to the main channel by cut banks on both sides. The bottom is 4 feet wide channel prone to some shifting with vegetation on each bank. Low water control is the 9" Par shall flume.

Rating No. 1 was developed based on the computation of 9" Parshall flume. Point of zero flow is 0.00 gage height.

Sixteen inspections of no flow were made during this water year.

Discharge. Discharge was computed by applying Rating No. 1 direct.

Remarks. Records good. 


\section{E1219 Sandia Canyon East of Power Plant}

Daily Mean Discharge in Cubic Feet per Second

Water Year October 2005 to September 2006

\begin{tabular}{|c|c|c|c|c|c|c|c|c|c|c|c|c|}
\hline DAY & OCT & NOV & DEC & JAN & FEB & MAR & APR & MAY & JUN & JUL & AUG & SEP \\
\hline 1 & 0 & 0 & 0 & 0 & 0 & 0 & 0 & 0 & 0 & 0 & .01 & 0 \\
\hline 2 & 0 & 0 & 0 & 0 & 0 & 0 & 0 & 0 & 0 & 0 & 0 & 0 \\
\hline 3 & 0 & 0 & 0 & 0 & 0 & 0 & 0 & 0 & 0 & .02 & 0 & 0 \\
\hline 4 & 0 & 0 & 0 & 0 & 0 & 0 & 0 & 0 & 0 & 0 & 0 & 0 \\
\hline 5 & 0 & 0 & 0 & 0 & 0 & 0 & 0 & 0 & 0 & 0 & .02 & 0 \\
\hline 6 & 0 & 0 & 0 & 0 & 0 & 0 & 0 & 0 & 0 & .01 & 0 & .01 \\
\hline 7 & 0 & 0 & 0 & 0 & 0 & 0 & 0 & 0 & 0 & 0 & .04 & 0 \\
\hline 8 & 0 & 0 & 0 & 0 & 0 & 0 & 0 & 0 & 0 & .01 & .04 & 0 \\
\hline 9 & 0 & 0 & 0 & 0 & 0 & 0 & 0 & 0 & 0 & 0 & 0 & 0 \\
\hline 10 & 0 & 0 & 0 & 0 & 0 & 0 & 0 & 0 & 0 & 0 & 0 & 0 \\
\hline 11 & 0 & 0 & 0 & 0 & 0 & 0 & 0 & 0 & 0 & 0 & 0 & 0 \\
\hline 12 & 0 & 0 & 0 & 0 & 0 & 0 & 0 & 0 & 0 & 0 & 0 & 0 \\
\hline 13 & 0 & 0 & 0 & 0 & 0 & 0 & 0 & 0 & 0 & 0 & 0 & 0 \\
\hline 14 & 0 & 0 & 0 & 0 & 0 & 0 & 0 & 0 & 0 & 0 & 0 & 0 \\
\hline 15 & 0 & 0 & 0 & 0 & 0 & 0 & 0 & 0 & 0 & 0 & 0 & 0 \\
\hline 16 & 0 & 0 & 0 & 0 & 0 & 0 & 0 & 0 & 0 & 0 & 0 & 0 \\
\hline 17 & 0 & 0 & 0 & 0 & 0 & 0 & 0 & 0 & 0 & 0 & 0 & 0 \\
\hline 18 & 0 & 0 & 0 & 0 & 0 & 0 & 0 & 0 & 0 & 0 & 0 & 0 \\
\hline 19 & 0 & 0 & 0 & 0 & 0 & 0 & 0 & 0 & 0 & 0 & .02 & 0 \\
\hline 20 & 0 & 0 & 0 & 0 & 0 & 0 & 0 & 0 & 0 & 0 & .01 & 0 \\
\hline 21 & 0 & 0 & 0 & 0 & 0 & 0 & 0 & 0 & 0 & .01 & 0 & 0 \\
\hline 22 & 0 & 0 & 0 & 0 & 0 & 0 & 0 & 0 & .01 & 0 & 0 & 0 \\
\hline 23 & 0 & 0 & 0 & 0 & 0 & 0 & 0 & 0 & 0 & 0 & 0 & 0 \\
\hline 24 & 0 & 0 & 0 & 0 & 0 & 0 & 0 & 0 & 0 & 0 & 0 & 0 \\
\hline 25 & 0 & 0 & 0 & 0 & 0 & 0 & 0 & 0 & 0 & 0 & .08 & 0 \\
\hline 26 & 0 & 0 & 0 & 0 & 0 & 0 & 0 & 0 & 0 & 0 & 0 & 0 \\
\hline 27 & 0 & 0 & 0 & 0 & 0 & 0 & 0 & 0 & 0 & 0 & 0 & 0 \\
\hline 28 & 0 & 0 & 0 & 0 & 0 & 0 & 0 & 0 & .01 & 0 & 0 & 0 \\
\hline 29 & 0 & 0 & 0 & 0 & ----- & 0 & 0 & 0 & .01 & 0 & 0 & 0 \\
\hline 30 & 0 & 0 & 0 & 0 & -.-- & 0 & 0 & 0 & 0 & 0 & 0 & 0 \\
\hline 31 & 0 & ----- & 0 & 0 & ----- & 0 & ------ & 0 & ----- & .01 & 0 & ----- \\
\hline Total & 0 & 0 & 0 & 0 & 0 & 0 & 0 & 0 & 0.03 & 0.06 & 0.22 & 0.01 \\
\hline Mean & 0 & 0 & 0 & 0 & 0 & 0 & 0 & 0 & .001 & .002 & .007 & 0 \\
\hline Max & 0 & 0 & 0 & 0 & 0 & 0 & 0 & 0 & .01 & .02 & .08 & .01 \\
\hline Min & 0 & 0 & 0 & 0 & 0 & 0 & 0 & 0 & 0 & 0 & 0 & 0 \\
\hline Acre-Ft & 0 & 0 & 0 & 0 & 0 & 0 & 0 & 0 & .06 & .12 & .44 & .02 \\
\hline Wtr Year & 2006 & Total & 0.32 & Mean & .001 & & Max & .08 & Min & 0 & Acre-Ft & .63 \\
\hline Cal Year & 2005 & Total & 0 & Mean & 0 & & $\operatorname{Max}$ & & Min & 0 & Acre-Ft & 0 \\
\hline
\end{tabular}




\section{E1225 Sandia Canyon Tributary at Heavy Equipment}

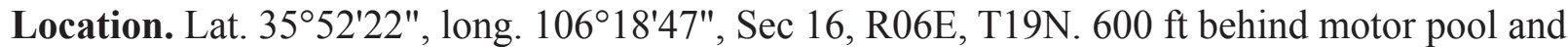
0.50 mile downstream from Diamond Drive, Los Alamos County.

Drainage Area. $0.0088 \mathrm{mi}^{2}$ (5.66 acres).

Period of Record. October 1, 2002, to September 30, 2006

Gage. Data logger and 12" Parshall flume. Elevation of gage is 7,323 ft above NGVD from GIS 9.1.

Remarks. Water discharge records good.

Extremes for Period of Record. Maximum discharge, $6.6 \mathrm{ft}^{3} / \mathrm{s}$, August 25, 2005, gage height $1.50 \mathrm{ft}$. No flow most of time.

Extremes for 2003 Water Year. Maximum discharge $4.0 \mathrm{ft}^{3} / \mathrm{s}$ at $1135 \mathrm{~h}$, July 20, gage height $1.22 \mathrm{ft}$. No flow most of time.

Extremes for 2004 Water Year. Maximum discharge, $4.49 \mathrm{ft}^{3} / \mathrm{s}$ at $1950 \mathrm{~h}$, September 14, gage height $1.08 \mathrm{ft}$. No flow most of time.

Extremes for 2005 Water Year. Maximum discharge, $3.92 \mathrm{ft}^{3} / \mathrm{s}$ at $0900 \mathrm{~h}$, October 5, 2004, gage height $2.32 \mathrm{ft}$. No flow most of time.

Extremes for Current Year. Maximum discharge, $6.6 \mathrm{ft}^{3} / \mathrm{s}$ at $1215 \mathrm{~h}$, August 25, gage height $1.50 \mathrm{ft}$. No flow most of time.

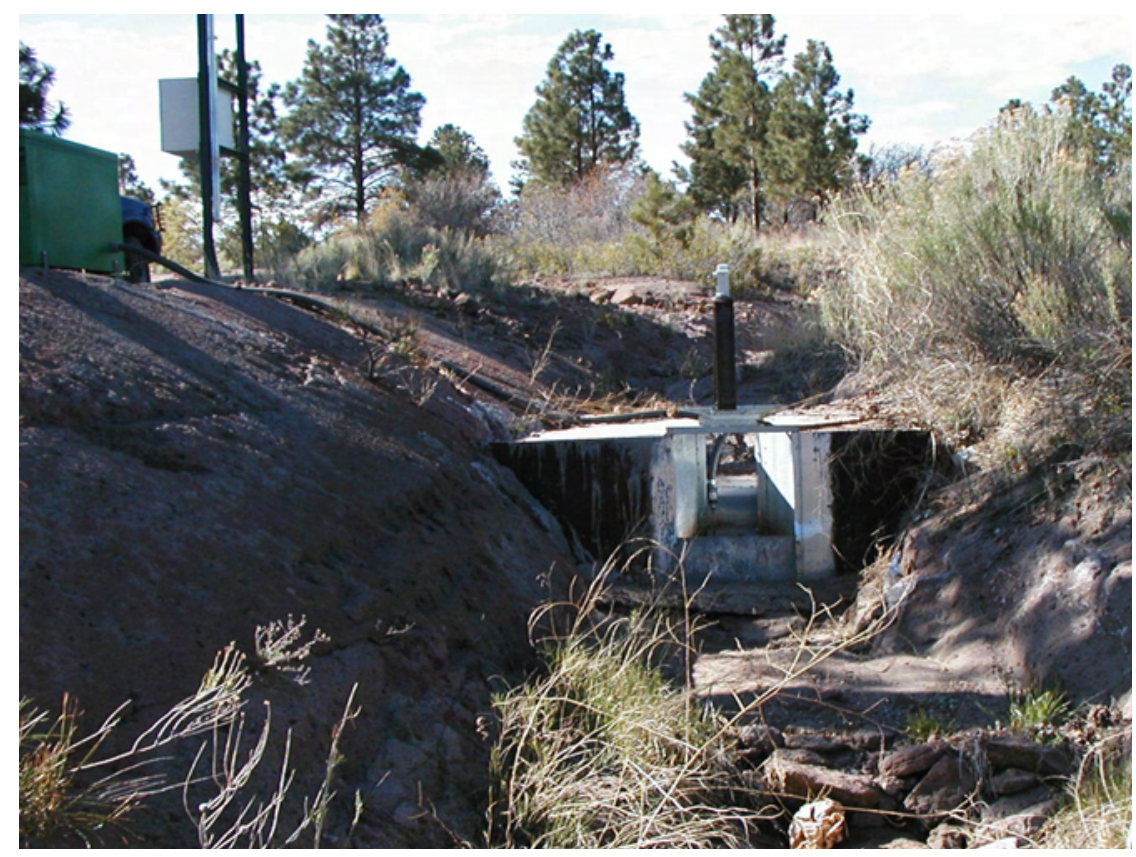




\section{E1225 Sandia Canyon Tributary at Heavy Equipment \\ Station Analysis \\ 2003 to 2006 Water Year}

Equipment. Sutron 8210 data logger with cellular phone telemetry with speech modem with a solar panel battery charging system are housed in a NEMA shelter on right bank. A millitroncs sonic probe stage sensor is mounted on top a 12" Para shall flume. The gaging station is also equipped with an ISCO pump sampler for water quality data collection and is housed in a separate shelter 4' $\times 4^{\prime}$ metal box which is triggered by the data logger. The staff in the 12 " Parshall flume is the reference gage. There is no provision for direct discharge measurements above wading stage.

Field Work. The station was visited thirty-four times during period of record for the purpose of making a discharge measurement and/or servicing the instrumentation. Field inspections for the gage are listed under site history files on the Hydstra database. Discharge measurements for the gage are listed under site gauging files on the Hydstra database.

Datum Correction. None.

Gage-Height Record. The data logger referenced to the outside staff gave a complete and satisfactory record for the year; except during the period from April 17-24 when data logger lost power. During this period of record after some flow event, flume would become silted on these days and were modified with Hydstra.

Rating. The channel is straight above and below gage. It is confined to the main channel by cut banks on both sides. The bottom is 10 feet wide channel prone to no shifting. Low water control is the 12" Parshall flume.

Rating No. 1 was developed based on the computation of 12" Parshall flume. Point of zero flow is 0.00 gage height.

Thirty-four inspections of no flow were made this period of record.

Discharge. Discharge was computed by applying Rating No. 1 direct.

Remarks. Records good. 


\section{E1225 Sandia Tributary at Heavy Equipment}

Daily Mean Discharge in Cubic Feet per Second

Water Year October 2002 to September 2003

\begin{tabular}{|c|c|c|c|c|c|c|c|c|c|c|c|c|}
\hline DAY & OCT & NOV & DEC & JAN & FEB & MAR & APR & MAY & JUN & JUL & AUG & SEP \\
\hline 1 & 0 & 0 & 0 & 0 & 0 & 0 & 0 & 0 & 0 & 0 & 0 & 0 \\
\hline 2 & 0 & 0 & 0 & 0 & 0 & 0 & 0 & 0 & 0 & 0 & 0 & 0 \\
\hline 3 & 0 & 0 & 0 & 0 & 0 & 0 & 0 & 0 & 0 & 0 & 0 & 0 \\
\hline 4 & 0 & 0 & 0 & 0 & 0 & 0 & 0 & 0 & 0 & 0 & 0 & 0 \\
\hline 5 & 0 & 0 & 0 & 0 & 0 & 0 & 0 & 0 & 0 & 0 & 0 & 0 \\
\hline 6 & .13 & 0 & 0 & 0 & 0 & 0 & 0 & 0 & 0 & 0 & 0 & 0 \\
\hline 7 & .08 & 0 & 0 & 0 & 0 & 0 & 0 & 0 & 0 & 0 & 0 & 0 \\
\hline 8 & 0 & 0 & 0 & 0 & 0 & 0 & 0 & 0 & 0 & 0 & 0 & 0 \\
\hline 9 & 0 & 0 & 0 & 0 & 0 & 0 & 0 & 0 & 0 & 0 & 0 & 0 \\
\hline 10 & 0 & 0 & 0 & 0 & 0 & 0 & 0 & 0 & 0 & 0 & 0 & 0 \\
\hline 11 & 0 & 0 & 0 & 0 & 0 & 0 & 0 & 0 & 0 & 0 & 0 & 0 \\
\hline 12 & 0 & 0 & 0 & 0 & 0 & 0 & 0 & 0 & 0 & 0 & 0 & 0 \\
\hline 13 & 0 & 0 & 0 & 0 & 0 & 0 & 0 & 0 & .02 & 0 & 0 & 0 \\
\hline 14 & 0 & 0 & 0 & 0 & 0 & 0 & 0 & 0 & 0 & 0 & 0 & 0 \\
\hline 15 & 0 & 0 & 0 & 0 & 0 & 0 & 0 & 0 & 0 & 0 & 0 & 0 \\
\hline 16 & 0 & 0 & 0 & 0 & 0 & 0 & 0 & 0 & 0 & 0 & 0 & 0 \\
\hline 17 & 0 & 0 & 0 & 0 & 0 & 0 & 0 & 0 & 0 & 0 & 0 & 0 \\
\hline 18 & 0 & 0 & 0 & 0 & 0 & 0 & 0 & 0 & 0 & 0 & 0 & 0 \\
\hline 19 & 0 & 0 & 0 & 0 & 0 & 0 & 0 & 0 & 0 & 0 & 0 & 0 \\
\hline 20 & 0 & 0 & 0 & 0 & 0 & 0 & 0 & 0 & 0 & .19 & 0 & 0 \\
\hline 21 & 0 & 0 & 0 & 0 & 0 & 0 & 0 & 0 & 0 & .06 & 0 & 0 \\
\hline 22 & 0 & 0 & 0 & 0 & 0 & 0 & 0 & 0 & 0 & .01 & 0 & 0 \\
\hline 23 & 0 & 0 & 0 & 0 & 0 & 0 & 0 & 0 & 0 & .05 & 0 & 0 \\
\hline 24 & 0 & 0 & 0 & 0 & 0 & 0 & 0 & .01 & 0 & 0 & 0 & 0 \\
\hline 25 & 0 & 0 & 0 & 0 & 0 & 0 & 0 & .57 & 0 & 0 & 0 & 0 \\
\hline 26 & 0 & 0 & 0 & 0 & 0 & 0 & 0 & .07 & 0 & .02 & 0 & 0 \\
\hline 27 & 0 & 0 & 0 & 0 & 0 & 0 & 0 & .04 & 0 & .04 & 0 & 0 \\
\hline 28 & 0 & 0 & 0 & 0 & 0 & 0 & 0 & 0 & 0 & .04 & 0 & 0 \\
\hline 29 & 0 & 0 & 0 & 0 & ---- & 0 & 0 & 0 & 0 & 0 & 0 & 0 \\
\hline 30 & 0 & 0 & 0 & 0 & ----- & 0 & 0 & 0 & 0 & 0 & 0 & 0 \\
\hline 31 & 0 & ----- & 0 & 0 & ----- & 0 & ---- & 0 & ----- & 0 & 0 & ---- \\
\hline Total & 0.21 & 0 & 0 & 0 & 0 & 0 & 0 & 0.69 & 0.02 & 0.41 & 0 & 0 \\
\hline Mean & .007 & 0 & 0 & 0 & 0 & 0 & 0 & .022 & .001 & .013 & 0 & 0 \\
\hline Max & .13 & 0 & 0 & 0 & 0 & 0 & 0 & .57 & .02 & .19 & 0 & 0 \\
\hline Min & 0 & 0 & 0 & 0 & 0 & 0 & 0 & 0 & 0 & 0 & 0 & 0 \\
\hline Acre-Ft & .42 & 0 & 0 & 0 & 0 & 0 & 0 & 1.4 & .04 & .81 & 0 & 0 \\
\hline Wtr Year & 2003 & Total & 1.33 & Mear & .00 & & Max & .57 & Min & 0 & Acre-Ft & 2.6 \\
\hline Cal Year & 2002 & Total & 20.02 & Mear & .05 & & Max & 3.1 & Min & 0 & Acre-Ft & 40 \\
\hline
\end{tabular}




\section{E1225 Sandia Tributary at Heavy Equipment}

Daily Mean Discharge in Cubic Feet per Second

Water Year October 2003 to September 2004

\begin{tabular}{|c|c|c|c|c|c|c|c|c|c|c|c|c|}
\hline DAY & OCT & NOV & DEC & JAN & FEB & MAR & APR & MAY & JUN & JUL & AUG & SEP \\
\hline 1 & 0 & 0 & 0 & 0 & 0 & 0 & 0 & 0 & 0 & 0 & 0 & 0 \\
\hline 2 & 0 & 0 & 0 & 0 & 0 & 0 & 0 & 0 & 0 & 0 & 0 & 0 \\
\hline 3 & 0 & 0 & 0 & 0 & 0 & 0 & 0 & 0 & 0 & 0 & 0 & 0 \\
\hline 4 & 0 & 0 & 0 & 0 & 0 & 0 & 0 & 0 & 0 & 0 & 0 & .01 \\
\hline 5 & 0 & 0 & 0 & 0 & 0 & 0 & 0 & 0 & 0 & 0 & 0 & 0 \\
\hline 6 & 0 & 0 & 0 & 0 & 0 & 0 & 0 & 0 & 0 & 0 & 0 & 0 \\
\hline 7 & 0 & 0 & 0 & 0 & 0 & 0 & 0 & 0 & 0 & 0 & 0 & 0 \\
\hline 8 & 0 & 0 & 0 & 0 & 0 & 0 & 0 & 0 & 0 & 0 & 0 & 0 \\
\hline 9 & 0 & 0 & 0 & 0 & 0 & 0 & 0 & 0 & 0 & 0 & 0 & .01 \\
\hline 10 & 0 & 0 & 0 & 0 & 0 & 0 & 0 & 0 & 0 & 0 & 0 & 0 \\
\hline 11 & 0 & 0 & 0 & 0 & 0 & 0 & 0 & 0 & 0 & 0 & 0 & .01 \\
\hline 12 & 0 & 0 & 0 & 0 & 0 & 0 & 0 & 0 & 0 & 0 & 0 & .01 \\
\hline 13 & 0 & 0 & 0 & 0 & 0 & 0 & 0 & 0 & 0 & 0 & 0 & .01 \\
\hline 14 & 0 & 0 & 0 & 0 & 0 & 0 & 0 & 0 & 0 & 0 & 0 & .09 \\
\hline 15 & 0 & 0 & 0 & 0 & 0 & 0 & 0 & 0 & 0 & 0 & 0 & 0 \\
\hline 16 & 0 & 0 & 0 & 0 & 0 & 0 & 0 & 0 & 0 & 0 & 0 & 0 \\
\hline 17 & 0 & 0 & 0 & 0 & 0 & 0 & 0 & $0^{*}$ & 0 & 0 & 0 & 0 \\
\hline 18 & 0 & 0 & 0 & 0 & 0 & 0 & 0 & $0^{*}$ & 0 & 0 & .08 & 0 \\
\hline 19 & 0 & 0 & 0 & 0 & 0 & 0 & 0 & $0^{*}$ & 0 & 0 & .07 & .03 \\
\hline 20 & 0 & 0 & 0 & 0 & 0 & 0 & 0 & $0^{*}$ & 0 & 0 & .07 & 0 \\
\hline 21 & 0 & 0 & 0 & 0 & 0 & 0 & 0 & $0^{*}$ & 0 & 0 & .03 & 0 \\
\hline 22 & 0 & 0 & 0 & 0 & 0 & 0 & 0 & $0^{*}$ & 0 & 0 & .03 & 0 \\
\hline 23 & 0 & 0 & 0 & 0 & 0 & 0 & 0 & $0^{*}$ & 0 & 0 & .10 & 0 \\
\hline 24 & 0 & 0 & 0 & 0 & 0 & 0 & 0 & $0^{*}$ & 0 & 0 & 0 & 0 \\
\hline 25 & 0 & 0 & 0 & 0 & 0 & 0 & 0 & 0 & 0 & 0 & 0 & .03 \\
\hline 26 & 0 & 0 & 0 & 0 & 0 & 0 & 0 & 0 & 0 & 0 & 0 & 0 \\
\hline 27 & 0 & 0 & 0 & 0 & 0 & 0 & 0 & 0 & 0 & 0 & 0 & .06 \\
\hline 28 & 0 & 0 & 0 & 0 & 0 & 0 & 0 & 0 & 0 & 0 & 0 & .02 \\
\hline 29 & 0 & 0 & 0 & 0 & 0 & 0 & 0 & 0 & 0 & 0 & 0 & 0 \\
\hline 30 & 0 & 0 & 0 & 0 & ------ & 0 & 0 & 0 & 0 & 0 & 0 & 0 \\
\hline 31 & 0 & ----- & 0 & 0 & ----- & 0 & ----- & 0 & ---- & 0 & 0 & --- \\
\hline Total & 0 & 0 & 0 & 0 & 0 & 0 & 0 & 0 & 0 & 0 & 0.38 & 0.28 \\
\hline Mean & 0 & 0 & 0 & 0 & 0 & 0 & 0 & 0 & 0 & 0 & .012 & .009 \\
\hline $\operatorname{Max}$ & 0 & 0 & 0 & 0 & 0 & 0 & 0 & 0 & 0 & 0 & .10 & .09 \\
\hline Min & 0 & 0 & 0 & 0 & 0 & 0 & 0 & 0 & 0 & 0 & 0 & 0 \\
\hline Acre-Ft & 0 & 0 & 0 & 0 & 0 & 0 & 0 & 0 & 0 & 0 & .75 & .56 \\
\hline Wtr Year & 2004 & Total & 0.66 & Mean & .002 & & Max & 10 & Min & 0 & Acre-Ft & 1.3 \\
\hline Cal Year & 2003 & Total & 1.12 & Mean & .003 & & Max & 57 & Min & 0 & Acre-Ft & 2.2 \\
\hline
\end{tabular}




\section{E1225 Sandia Tributary at Heavy Equipment}

Daily Mean Discharge in Cubic Feet per Second

Water Year October 2004 to September 2005

\begin{tabular}{|c|c|c|c|c|c|c|c|c|c|c|c|c|}
\hline DAY & OCT & NOV & DEC & JAN & FEB & MAR & APR & MAY & JUN & JUL & AUG & SEP \\
\hline 1 & 0 & 0 & 0 & 0 & 0 & 0 & 0 & 0 & 0 & 0 & 0 & 0 \\
\hline 2 & 0 & 0 & 0 & 0 & 0 & 0 & 0 & 0 & 0 & 0 & 0 & 0 \\
\hline 3 & 0 & 0 & 0 & 0 & 0 & 0 & 0 & .05 & 0 & 0 & 0 & 0 \\
\hline 4 & 0 & 0 & 0 & 0 & 0 & 0 & 0 & 0 & 0 & 0 & .03 & 0 \\
\hline 5 & .06 & 0 & 0 & 0 & 0 & 0 & 0 & 0 & 0 & 0 & 0 & 0 \\
\hline 6 & 0 & 0 & 0 & 0 & 0 & 0 & 0 & 0 & 0 & 0 & 0 & 0 \\
\hline 7 & 0 & 0 & 0 & 0 & 0 & 0 & 0 & 0 & 0 & 0 & 0 & 0 \\
\hline 8 & 0 & 0 & 0 & 0 & 0 & 0 & 0 & 0 & 0 & 0 & 0 & 0 \\
\hline 9 & 0 & 0 & 0 & 0 & 0 & 0 & 0 & 0 & 0 & 0 & 0 & 0 \\
\hline 10 & 0 & 0 & 0 & 0 & 0 & 0 & 0 & 0 & 0 & 0 & 0 & 0 \\
\hline 11 & .10 & 0 & 0 & 0 & 0 & 0 & 0 & 0 & 0 & 0 & .01 & 0 \\
\hline 12 & 0 & 0 & 0 & 0 & 0 & 0 & 0 & 0 & 0 & 0 & .07 & 0 \\
\hline 13 & .02 & .02 & 0 & 0 & 0 & 0 & 0 & 0 & 0 & 0 & .01 & 0 \\
\hline 14 & 0 & 0 & 0 & 0 & 0 & 0 & 0 & 0 & 0 & 0 & 0 & 0 \\
\hline 15 & 0 & 0 & 0 & 0 & 0 & 0 & 0 & 0 & 0 & 0 & 0 & 0 \\
\hline 16 & 0 & 0 & 0 & 0 & 0 & 0 & .08 & 0 & 0 & 0 & 0 & 0 \\
\hline 17 & 0 & 0 & 0 & 0 & 0 & 0 & $0^{*}$ & 0 & 0 & .03 & 0 & 0 \\
\hline 18 & 0 & 0 & 0 & 0 & 0 & 0 & $0^{*}$ & 0 & 0 & .02 & 0 & 0 \\
\hline 19 & 0 & 0 & 0 & 0 & 0 & 0 & $0^{*}$ & 0 & 0 & .01 & 0 & 0 \\
\hline 20 & 0 & .02 & 0 & 0 & 0 & .01 & $0^{*}$ & 0 & 0 & .03 & 0 & 0 \\
\hline 21 & 0 & 0 & 0 & 0 & 0 & 0 & $0^{*}$ & 0 & 0 & 0 & 0 & 0 \\
\hline 22 & 0 & 0 & 0 & 0 & 0 & 0 & $0^{*}$ & 0 & 0 & 0 & .03 & 0 \\
\hline 23 & 0 & 0 & 0 & 0 & 0 & 0 & $0^{*}$ & 0 & 0 & 0 & 0 & 0 \\
\hline 24 & 0 & 0 & 0 & 0 & 0 & 0 & .09 & 0 & 0 & 0 & .09 & 0 \\
\hline 25 & .02 & 0 & 0 & 0 & 0 & .01 & 0 & 0 & 0 & 0 & 0 & 0 \\
\hline 26 & 0 & 0 & 0 & 0 & 0 & .01 & 0 & 0 & 0 & 0 & 0 & 0 \\
\hline 27 & .04 & 0 & 0 & 0 & 0 & 0 & 0 & 0 & 0 & 0 & 0 & 0 \\
\hline 28 & 0 & 0 & 0 & 0 & 0 & 0 & 0 & 0 & 0 & 0 & 0 & 0 \\
\hline 29 & 0 & 0 & 0 & 0 & ----- & 0 & 0 & 0 & 0 & 0 & 0 & 0 \\
\hline 30 & 0 & 0 & 0 & 0 & ---- & 0 & 0 & 0 & 0 & 0 & 0 & 0 \\
\hline 31 & 0 & ---- & 0 & 0 & ----- & 0 & ----- & 0 & ---- & 0 & 0 & -.-- \\
\hline Total & 0.24 & 0.04 & 0 & 0 & 0 & 0.03 & 0.17 & 0.05 & 0 & 0.09 & 0.24 & 0 \\
\hline Mean & .008 & .001 & 0 & 0 & 0 & .001 & .006 & .002 & 0 & .003 & .008 & 0 \\
\hline Max & .10 & .02 & 0 & 0 & 0 & .01 & .09 & .05 & 0 & .03 & .09 & 0 \\
\hline Min & 0 & 0 & 0 & 0 & 0 & 0 & 0 & 0 & 0 & 0 & 0 & 0 \\
\hline Acre-Ft & .48 & .08 & 0 & 0 & 0 & .06 & .34 & .10 & 0 & .18 & .48 & 0 \\
\hline Wtr Year & 2005 & Total & 0.86 & Mean & .0 & & hax & 0 & Min & 0 & Acre-Ft & 1.7 \\
\hline Cal Year & 2004 & Total & 0.94 & Mean & .0 & & hax & 0 & Min & 0 & Acre-Ft & 1.9 \\
\hline
\end{tabular}




\section{E1225 Sandia Tributary at Heavy Equipment}

Daily Mean Discharge in Cubic Feet per Second

Water Year October 2005 to September 2006

\begin{tabular}{|c|c|c|c|c|c|c|c|c|c|c|c|c|}
\hline DAY & OCT & NOV & DEC & JAN & FEB & MAR & APR & MAY & JUN & JUL & AUG & SEP \\
\hline 1 & 0 & 0 & 0 & 0 & 0 & 0 & 0 & 0 & 0 & .01 & .05 & 0 \\
\hline 2 & 0 & 0 & 0 & 0 & 0 & 0 & 0 & 0 & 0 & 0 & 0 & 0 \\
\hline 3 & 0 & 0 & 0 & 0 & 0 & 0 & 0 & 0 & 0 & .09 & 0 & 0 \\
\hline 4 & 0 & 0 & 0 & 0 & 0 & 0 & 0 & 0 & 0 & .01 & .01 & 0 \\
\hline 5 & 0 & 0 & 0 & 0 & 0 & 0 & 0 & 0 & 0 & .02 & .10 & 0 \\
\hline 6 & 0 & 0 & 0 & 0 & 0 & 0 & 0 & 0 & 0 & .03 & 0 & 0 \\
\hline 7 & 0 & 0 & 0 & 0 & 0 & 0 & 0 & 0 & 0 & .01 & .10 & 0 \\
\hline 8 & 0 & 0 & 0 & 0 & 0 & 0 & 0 & 0 & 0 & .03 & .12 & 0 \\
\hline 9 & 0 & 0 & 0 & 0 & 0 & 0 & 0 & 0 & 0 & .02 & .09 & 0 \\
\hline 10 & 0 & 0 & 0 & 0 & 0 & 0 & 0 & 0 & 0 & 0 & .05 & 0 \\
\hline 11 & 0 & 0 & 0 & 0 & 0 & 0 & 0 & 0 & 0 & 0 & 0 & 0 \\
\hline 12 & 0 & 0 & 0 & 0 & 0 & 0 & 0 & 0 & 0 & 0 & 0 & 0 \\
\hline 13 & 0 & 0 & 0 & 0 & 0 & 0 & 0 & 0 & 0 & 0 & 0 & 0 \\
\hline 14 & 0 & 0 & 0 & 0 & 0 & 0 & 0 & 0 & 0 & 0 & .01 & 0 \\
\hline 15 & 0 & 0 & 0 & 0 & 0 & 0 & 0 & 0 & 0 & 0 & 0 & 0 \\
\hline 16 & .02 & 0 & 0 & 0 & 0 & 0 & 0 & 0 & 0 & 0 & 0 & 0 \\
\hline 17 & .03 & 0 & 0 & 0 & 0 & 0 & 0 & 0 & 0 & 0 & 0 & 0 \\
\hline 18 & 0 & 0 & 0 & 0 & 0 & 0 & 0 & 0 & 0 & 0 & 0 & 0 \\
\hline 19 & .14 & 0 & 0 & 0 & 0 & 0 & 0 & 0 & 0 & 0 & .04 & 0 \\
\hline 20 & .13 & 0 & 0 & 0 & 0 & 0 & 0 & 0 & 0 & 0 & .03 & 0 \\
\hline 21 & .08 & 0 & 0 & 0 & 0 & 0 & 0 & 0 & 0 & .01 & .01 & 0 \\
\hline 22 & .10 & 0 & 0 & 0 & 0 & 0 & 0 & 0 & .02 & 0 & .01 & 0 \\
\hline 23 & .01 & 0 & 0 & 0 & 0 & 0 & 0 & 0 & 0 & 0 & 0 & .04 \\
\hline 24 & 0 & 0 & 0 & 0 & 0 & 0 & 0 & 0 & 0 & 0 & 0 & 0 \\
\hline 25 & 0 & 0 & 0 & 0 & 0 & 0 & 0 & 0 & 0 & 0 & .19 & 0 \\
\hline 26 & 0 & 0 & 0 & 0 & 0 & 0 & 0 & 0 & 0 & .01 & 0 & 0 \\
\hline 27 & 0 & 0 & 0 & 0 & 0 & 0 & 0 & 0 & 0 & 0 & 0 & 0 \\
\hline 28 & 0 & 0 & 0 & 0 & 0 & 0 & 0 & 0 & 0 & .01 & 0 & 0 \\
\hline 29 & 0 & 0 & 0 & 0 & ---- & 0 & 0 & 0 & .06 & 0 & 0 & 0 \\
\hline 30 & 0 & 0 & 0 & 0 & ----- & 0 & 0 & 0 & .01 & 0 & 0 & 0 \\
\hline 31 & 0 & ----- & 0 & 0 & ----- & 0 & ---- & 0 & ----- & .02 & 0 & 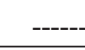 \\
\hline Total & 0.51 & 0 & 0 & 0 & 0 & 0 & 0 & 0 & 0.09 & 0.27 & 0.81 & 0.04 \\
\hline Mean & .016 & 0 & 0 & 0 & 0 & 0 & 0 & 0 & .003 & .009 & .026 & .001 \\
\hline Max & .14 & 0 & 0 & 0 & 0 & 0 & 0 & 0 & .06 & .09 & .19 & .04 \\
\hline Min & 0 & 0 & 0 & 0 & 0 & 0 & 0 & 0 & 0 & 0 & 0 & 0 \\
\hline Acre-Ft & 1.0 & 0 & 0 & 0 & 0 & 0 & 0 & 0 & .18 & .54 & 1.6 & .08 \\
\hline Wtr Year & 2006 & Total & 1.72 & Mean & .005 & & Max & 19 & Min & 0 & Acre-Ft & 3.4 \\
\hline Cal Year & 2005 & Total & 1.09 & Mean & .003 & & Max & 14 & Min & 0 & Acre-Ft & 2.2 \\
\hline
\end{tabular}




\section{E123 Sandia below Wetlands}

Location. Lat. 3552'23.0", long. 106'18'35", SW 1/4 SE 1/4 sec. 14, T. 19 N, R. 6 E, 0.15 mile behind Los Alamos County Land 11 off Jemez Road, and 0.80 mile downstream from Diamond Drive.

Drainage Area. $0.29 \mathrm{mi}^{2}$.

Period of Record. August 1, 1999, to September 30, 2006.

Revised Record. Drainage Area (this report).

Gage. Data logger with cellular telemetry. Elevation of gage is 7,204 ft above NGVD from GIS 9.1.

Remarks. Water discharge records good.

Average Discharge. $6 \mathrm{yr}, 0.63 \mathrm{ft}$ / $/ \mathrm{s}, 456$ acre-ft/year.

Extremes for Period of Record. Maximum discharge $88 \mathrm{ft}^{3} / \mathrm{s}$, August 23, 2003, gage height $4.23 \mathrm{ft}$; minimum daily $0.08 \mathrm{ft}^{3} / \mathrm{s}$, June 22, 2003.

Extremes for Current Water Year. Maximum discharge $75 \mathrm{ft}^{3} / \mathrm{s}$ at $1220 \mathrm{~h}$, August 25, gage height $4.04 \mathrm{ft}$; minimum daily $0.24 \mathrm{ft}^{3} / \mathrm{s}$, May 28.

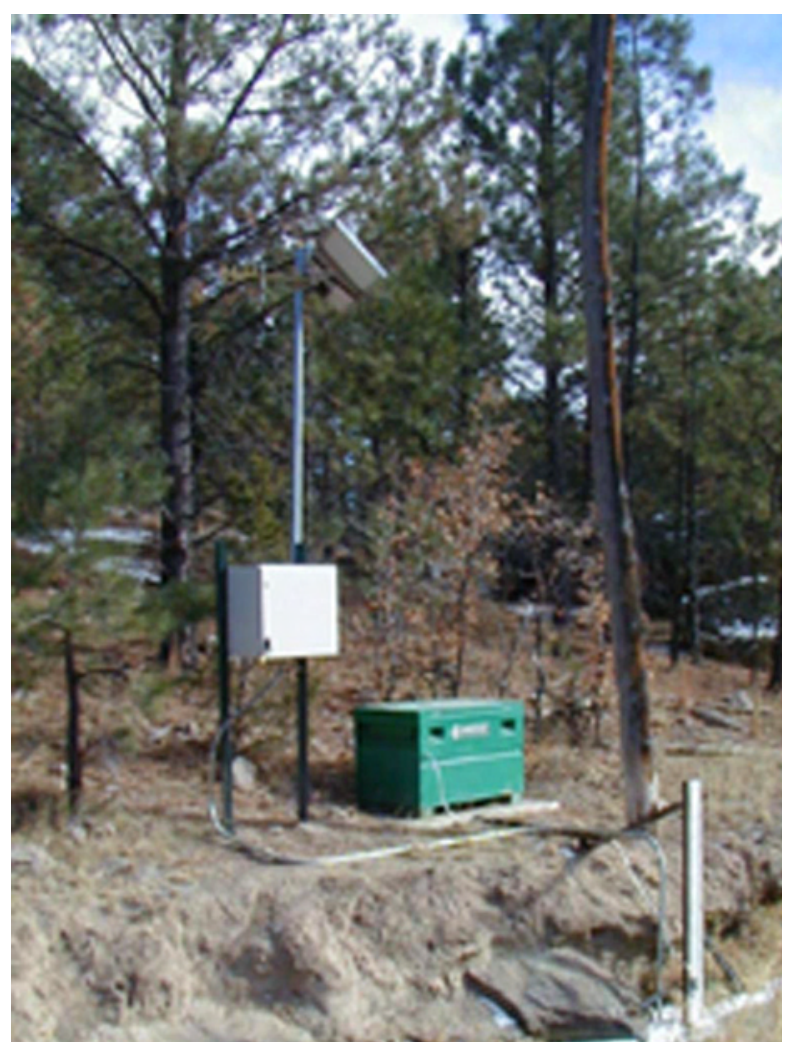




\section{E123 Sandia below Wetlands \\ Station Analysis \\ 2006 Water Year}

Equipment. Sutron 8210 data logger (5-min. interval) with a Sutron self-contained bubbler gage/accubar as stage sensor. Data logger is equipped with cellular speech modem telemetry. The station is also equipped with ISCO brand auto sampler. Outside staff is reference gage. On July 21, 2003, a temperature probe was installed (30 min, interval). No provision for discharge measurements above wading stages.

Field Work. The station was visited thirty five times for the purpose of making a discharge measurement and/or servicing the instrumentation. Field inspections for the gage are listed under site history files on the Hydstra database. Discharge measurements for the gage are listed under site gauging files on the Hydstra database.

Datum Correction. None. Levels of July 25, 2005, found gage to correct datum.

Gage-Height Record. The recorder referenced to the inside gave a complete and satisfactory record for year, except January 29-February 17 when the bubbler had failed and was replaced.

Rating. Channel is trapezoidal with rock outcrop bed and some small depositional bars in the pools. Banks have some grass but it is not very tall or thick. Channel is straight for about 100 feet above and below gage.

Rating No. 2 was developed based on the measurements made this year. Shifts are small and mostly negative caused by small deposition near gage or some bank slough during high flows. They have been distributed using variable diagrams with no shifts applied on the peak flows.

Sixteen discharge measurements (No. 60-76) and nineteen inspections were available for this analysis.

Discharge. Computed from Rating No. 2 with shifts applied by "V" diagrams.

Remarks. Records good. 


\section{E123 Sandia below Wetlands}

Daily Mean Discharge in Cubic Feet per Second

Water Year October 2005 to September 2006

\begin{tabular}{|c|c|c|c|c|c|c|c|c|c|c|c|c|}
\hline DAY & OCT & NOV & DEC & JAN & FEB & MAR & APR & MAY & JUN & JUL & AUG & SEP \\
\hline 1 & .65 & .46 & .50 & .52 & $.29^{*}$ & .57 & .69 & .38 & .33 & .38 & 1.1 & .81 \\
\hline 2 & .44 & .43 & .62 & .52 & $.18^{*}$ & .50 & .41 & .40 & .42 & .64 & .45 & .44 \\
\hline 3 & .67 & .36 & .64 & .52 & $.26^{*}$ & .66 & .65 & .36 & .31 & 1.6 & .62 & .39 \\
\hline 4 & .60 & .50 & .67 & .50 & $.27^{\star}$ & .52 & .43 & .43 & .40 & .52 & .69 & .40 \\
\hline 5 & .41 & .37 & .74 & .73 & $.13^{*}$ & .70 & .68 & .69 & .42 & 1.1 & 3.6 & .48 \\
\hline 6 & .46 & .54 & .39 & .54 & $.16^{*}$ & .70 & .50 & .24 & .37 & 1.2 & 1.3 & 1.2 \\
\hline 7 & .47 & .53 & .49 & .57 & $.38^{*}$ & .41 & .56 & .32 & .56 & .44 & 4.4 & .43 \\
\hline 8 & .42 & .42 & .71 & .75 & .42 & .61 & .32 & .47 & .36 & 1.2 & 3.5 & .57 \\
\hline 9 & 1.4 & .43 & .53 & .71 & .43 & .66 & .50 & .35 & .45 & .93 & .55 & .42 \\
\hline 10 & 1.0 & .60 & .38 & .60 & .30 & .56 & .39 & .33 & .26 & .92 & .48 & .52 \\
\hline 11 & .54 & .61 & .46 & .70 & .46 & .75 & .54 & .61 & .46 & .46 & .40 & .81 \\
\hline 12 & .48 & .40 & .75 & .68 & .46 & .48 & .49 & .29 & .36 & .55 & .69 & .49 \\
\hline 13 & .40 & .41 & .38 & .58 & .36 & .57 & .44 & .33 & .31 & .53 & .61 & .48 \\
\hline 14 & .46 & .44 & .38 & .46 & .20 & .42 & .39 & .33 & .27 & .72 & .78 & .59 \\
\hline 15 & 1.1 & .43 & .81 & .49 & .07 & .60 & .43 & .41 & .33 & .68 & .98 & .54 \\
\hline 16 & .65 & .45 & .40 & .59 & .62 & .47 & .49 & .37 & .34 & .59 & .51 & .30 \\
\hline 17 & .47 & .55 & .46 & .63 & .53 & .57 & .37 & .56 & .25 & .59 & .51 & .32 \\
\hline 18 & .69 & .28 & .66 & .65 & .60 & .54 & .51 & .38 & .33 & .51 & .39 & .54 \\
\hline 19 & .87 & .53 & 1.2 & .42 & .59 & .82 & .43 & .50 & .22 & .45 & .48 & .35 \\
\hline 20 & .48 & .45 & .38 & .70 & .62 & .59 & .33 & .39 & .24 & .60 & 2.0 & .68 \\
\hline 21 & .57 & .71 & .60 & .54 & .70 & .52 & .38 & .47 & .28 & .58 & 1.2 & .45 \\
\hline 22 & .54 & .58 & .62 & .62 & .56 & .70 & .47 & .39 & 1.5 & .90 & 1.0 & .58 \\
\hline 23 & .70 & .46 & .34 & .88 & .51 & .71 & .35 & .34 & .29 & .50 & .42 & .35 \\
\hline 24 & .66 & .44 & .32 & .53 & .56 & .50 & .45 & .34 & .45 & .40 & .43 & .52 \\
\hline 25 & .65 & .40 & .57 & .59 & .52 & .51 & .41 & .32 & .43 & .64 & .49 & .48 \\
\hline 26 & .40 & .50 & .46 & .50 & .75 & .50 & .28 & .37 & .57 & .37 & 6.2 & .53 \\
\hline 27 & .51 & .54 & .49 & .37 & .63 & .69 & .47 & .30 & .40 & .46 & .70 & .37 \\
\hline 28 & .50 & .73 & .48 & .69 & .56 & .60 & .46 & .19 & .81 & .46 & .44 & .57 \\
\hline 29 & .36 & .42 & .48 & $.47^{*}$ & ----- & .54 & .52 & .26 & 1.1 & .77 & .55 & .44 \\
\hline 30 & .47 & .51 & .31 & $.38^{*}$ & ----- & .60 & .35 & .31 & .44 & .37 & .48 & .48 \\
\hline 31 & .47 & ------ & .54 & $.54^{*}$ & ------- & .42 & --נ--נ- & .33 & ----- & .83 & .37 & - \\
\hline Total & 18.49 & 14.48 & 16.76 & 17.97 & 12.12 & 17.99 & 13.69 & 11.76 & 13.26 & 20.68 & 36.38 & 15.53 \\
\hline Mean & .60 & .48 & .54 & .58 & .43 & .58 & .46 & .38 & .44 & .67 & 1.17 & .52 \\
\hline Max & 1.4 & .73 & 1.2 & .88 & .75 & .82 & .69 & .69 & 1.5 & 1.6 & 6.2 & 1.2 \\
\hline Min & .36 & .28 & .31 & .37 & .07 & .41 & .28 & .19 & .22 & .37 & .37 & .30 \\
\hline Acre-Ft & 37 & 29 & 33 & 36 & 24 & 36 & 27 & 23 & 26 & 41 & 72 & 31 \\
\hline Wtr Year & 2006 & Total & 209.11 & $\mathrm{Me}$ & .57 & & Max & 5.2 & Min & .07 & Acre-Ft & 415 \\
\hline Cal Year & 2005 & Total & 304.39 & $\mathrm{Me}$ & .83 & & $\operatorname{Max}$ & 9.4 & Min & . 16 & Acre-Ft & 604 \\
\hline
\end{tabular}




\section{E125 Sandia above SR 4}

Location. Lat. 3551'32", long. 106 13 '34", SE 1/4 SW 1/4 sec. 20, T. 19 N, R.7 E, Santa Fe County, on right bank 0.25 mile north of East Jemez Road and 0.5 mile upstream from SR 4.

Drainage Area. $2.05 \mathrm{mi}^{2}$.

Period of Record. October 1, 1994, to September 30, 2006.

Revised Record. Drainage Area (this report).

Gage. Data logger with cellular telemetry and concrete control. Elevation of gage is $6,495 \mathrm{ft}$. above NGVD from GIS 9.1.

Remarks. Water discharge records fair.

Average Discharge. $12 \mathrm{yr}, 0.002 \mathrm{ft}^{3} / \mathrm{s}, 1.45$ acre-ft/yr.

Extremes for Period of Record. Maximum discharge $59 \mathrm{ft}^{3} / \mathrm{s}$, August 25, 2006, gage height $3.60 \mathrm{ft}$ (from slope-area measurement). No flow most of time.

Extremes for Current Water Year. Maximum discharge $59 \mathrm{ft}^{3} / \mathrm{s}$ at $1425 \mathrm{~h}$, August 25, gage height $3.60 \mathrm{ft}$ (from slope-area measurement). No flow most of time.

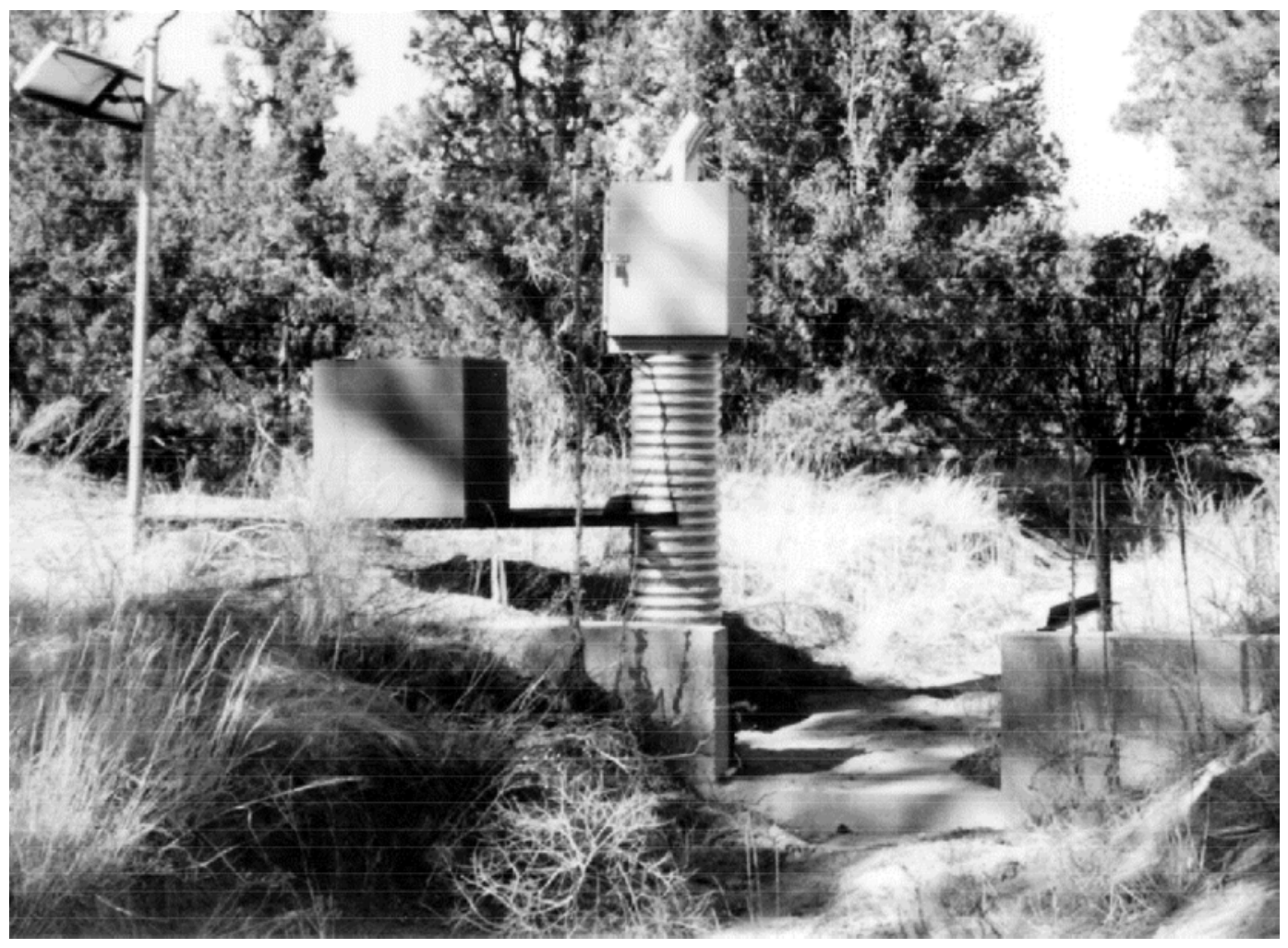




\section{E125 Sandia above SR 4 \\ Station Analysis \\ 2006 Water Year}

Equipment. Sutron 8210 data logger referenced to outside staff with cellular phone and speech modem. All equipment housed in NEMA shelter $24 " \times 24 " \times 30 "$ on an 18" CMP well on left bank. ISCO model 3700 automatic sampler is housed in auxiliary shelter and is triggered by stage through the Sutron data logger. Control is concrete broad crested weir. No provision for measurements above wading stages.

Field Work. The station was visited fifteen times for the purpose of making a discharge measurement and/or servicing the instrumentation. Field inspections for the gage are listed under site history files on the Hydstra database. Discharge measurements for the gage are listed under site gauging files on the Hydstra database.

Datum Correction. None from levels.

Gage-Height Record. The data logger referenced to the outside staff gave a complete and satisfactory record.

Rating. Channel is straight for 150 feet above and 100 feet below gage. Bed material is sand, vegetation on banks, and bottom is well armored.

Rating No. 1 is from theoretical points computed from broad-crested weir formula from US Geological Survey (USGS)-Techniques of Water Resources Investigations (TWRI). Worksheet is record folder that shows computation, including estimated velocity head used in computation because " $p$ " in equation was functionally zero. Rating No. 1 is considered fair.

During the water year, two measurements (No. 1-2) were made, number 1 being a slope area measurement of peak flow. Fifteen inspections of no flow were used to develop a "V" diagram shift needed to adjust to PZF. Measurement number 2 of high flow and a critical depth computation.

Slope area measurement was peak of record.

Discharge. Computed from Rating No.1 without shift correction.

Remarks. Records good. 


\section{E125 Sandia above SR 4}

Daily Mean Discharge in Cubic Feet per Second

Water Year October 2005 to September 2006

\begin{tabular}{|c|c|c|c|c|c|c|c|c|c|c|c|c|}
\hline DAY & OCT & NOV & DEC & JAN & FEB & MAR & APR & MAY & JUN & JUL & AUG & SEP \\
\hline 1 & 0 & 0 & 0 & 0 & 0 & 0 & 0 & 0 & 0 & 0 & 0 & 0 \\
\hline 2 & 0 & 0 & 0 & 0 & 0 & 0 & 0 & 0 & 0 & 0 & 0 & 0 \\
\hline 3 & 0 & 0 & 0 & 0 & 0 & 0 & 0 & 0 & 0 & 0 & 0 & 0 \\
\hline 4 & 0 & 0 & 0 & 0 & 0 & 0 & 0 & 0 & 0 & 0 & 0 & 0 \\
\hline 5 & 0 & 0 & 0 & 0 & 0 & 0 & 0 & 0 & 0 & 0 & 0 & 0 \\
\hline 6 & 0 & 0 & 0 & 0 & 0 & 0 & 0 & 0 & 0 & 0 & 0 & 0 \\
\hline 7 & 0 & 0 & 0 & 0 & 0 & 0 & 0 & 0 & 0 & 0 & 0 & 0 \\
\hline 8 & 0 & 0 & 0 & 0 & 0 & 0 & 0 & 0 & 0 & 0 & .03 & 0 \\
\hline 9 & 0 & 0 & 0 & 0 & 0 & 0 & 0 & 0 & 0 & 0 & 0 & 0 \\
\hline 10 & 0 & 0 & 0 & 0 & 0 & 0 & 0 & 0 & 0 & 0 & 0 & 0 \\
\hline 11 & 0 & 0 & 0 & 0 & 0 & 0 & 0 & 0 & 0 & 0 & 0 & 0 \\
\hline 12 & 0 & 0 & 0 & 0 & 0 & 0 & 0 & 0 & 0 & 0 & 0 & 0 \\
\hline 13 & 0 & 0 & 0 & 0 & 0 & 0 & 0 & 0 & 0 & 0 & 0 & 0 \\
\hline 14 & 0 & 0 & 0 & 0 & 0 & 0 & 0 & 0 & 0 & 0 & 0 & 0 \\
\hline 15 & 0 & 0 & 0 & 0 & 0 & 0 & 0 & 0 & 0 & 0 & 0 & 0 \\
\hline 16 & 0 & 0 & 0 & 0 & 0 & 0 & 0 & 0 & 0 & 0 & 0 & 0 \\
\hline 17 & 0 & 0 & 0 & 0 & 0 & 0 & 0 & 0 & 0 & 0 & 0 & 0 \\
\hline 18 & 0 & 0 & 0 & 0 & 0 & 0 & 0 & 0 & 0 & 0 & 0 & 0 \\
\hline 19 & 0 & 0 & 0 & 0 & 0 & 0 & 0 & 0 & 0 & 0 & 0 & 0 \\
\hline 20 & 0 & 0 & 0 & 0 & 0 & 0 & 0 & 0 & 0 & 0 & 0 & 0 \\
\hline 21 & 0 & 0 & 0 & 0 & 0 & 0 & 0 & 0 & 0 & 0 & 0 & 0 \\
\hline 22 & 0 & 0 & 0 & 0 & 0 & 0 & 0 & 0 & 0 & 0 & 0 & 0 \\
\hline 23 & 0 & 0 & 0 & 0 & 0 & 0 & 0 & 0 & 0 & 0 & 0 & 0 \\
\hline 24 & 0 & 0 & 0 & 0 & 0 & 0 & 0 & 0 & 0 & 0 & 0 & 0 \\
\hline 25 & 0 & 0 & 0 & 0 & 0 & 0 & 0 & 0 & 0 & 0 & 2.2 & 0 \\
\hline 26 & 0 & 0 & 0 & 0 & 0 & 0 & 0 & 0 & 0 & 0 & 0 & 0 \\
\hline 27 & 0 & 0 & 0 & 0 & 0 & 0 & 0 & 0 & 0 & 0 & 0 & 0 \\
\hline 28 & 0 & 0 & 0 & 0 & 0 & 0 & 0 & 0 & 0 & 0 & 0 & 0 \\
\hline 29 & 0 & 0 & 0 & 0 & ------ & 0 & 0 & 0 & 0 & 0 & 0 & 0 \\
\hline 30 & 0 & 0 & 0 & 0 & ------ & 0 & 0 & 0 & 0 & 0 & 0 & 0 \\
\hline 31 & 0 & ----- & 0 & 0 & ------ & 0 & ------ & 0 & ------ & 0 & 0 & ----- \\
\hline Total & 0 & 0 & 0 & 0 & 0 & 0 & 0 & 0 & 0 & 0 & 2.23 & 0 \\
\hline Mean & 0 & 0 & 0 & 0 & 0 & 0 & 0 & 0 & 0 & 0 & .072 & 0 \\
\hline Max & 0 & 0 & 0 & 0 & 0 & 0 & 0 & 0 & 0 & 0 & 2.2 & 0 \\
\hline Min & 0 & 0 & 0 & 0 & 0 & 0 & 0 & 0 & 0 & 0 & 0 & 0 \\
\hline Acre-Ft & 0 & 0 & 0 & 0 & 0 & 0 & 0 & 0 & 0 & 0 & 4.4 & 0 \\
\hline Wtr Year & 2006 & Total & 2.23 & Mean & .006 & & Max & 2.2 & Min & 0 & Acre-Ft & 4.4 \\
\hline Cal Year & 2005 & Total & 0.15 & Mean & 0 & & Max & .15 & Min & 0 & Acre-Ft & .30 \\
\hline
\end{tabular}




\section{E200 Mortandad below Effluent Canyon}

Location. Lat. 3551'55", long. 106¹7'46”, SW 1/4 NE 1/2 sec. 22, T. 19 N, R. 6 E, Los Alamos County, 0.25 mile north of LANL TA-50, 0.25 mile below TA-50 outfall, and 0.6 mile north of Pajarito Road.

Drainage Area. $0.49 \mathrm{mi}^{2}$.

Period of Record. May 10, 1995, to September 30, 2006.

Gage. Data logger with cellular telemetry and a "Walnut Gulch" flume as low-water control. Elevation of gage is 7,062.50 ft above NGVD from GIS 9.1.

Remarks. Water discharge records fair, except for estimated daily discharges, which are poor. Flow is mostly effluent from LANL TA-50, liquid radiological waste plant.

Average Discharge. $12 \mathrm{yr}, 0.05 \mathrm{ft}^{3} / \mathrm{s}, 36$ acre-ft/yr.

Extremes outside Period of Record. Flow of $34 \mathrm{ft}^{3} / \mathrm{s}$ occurred August 19, 1970, gage height $3.07 \mathrm{ft}$, from old data files of USGS.

Extremes for Period of Record. Maximum discharge $448 \mathrm{ft}^{3} / \mathrm{s}$, August 25, 2006, gage height $5.38 \mathrm{ft}$. (from critical depth computation of flood marks). No flow at times.

Extremes for Current Water Year. Maximum discharge $448 \mathrm{ft}^{3} / \mathrm{s}$, at $1240 \mathrm{~h}$, August 25, 2006, gage height $5.38 \mathrm{ft}$. (from critical depth computation of flood marks). No flow at times.

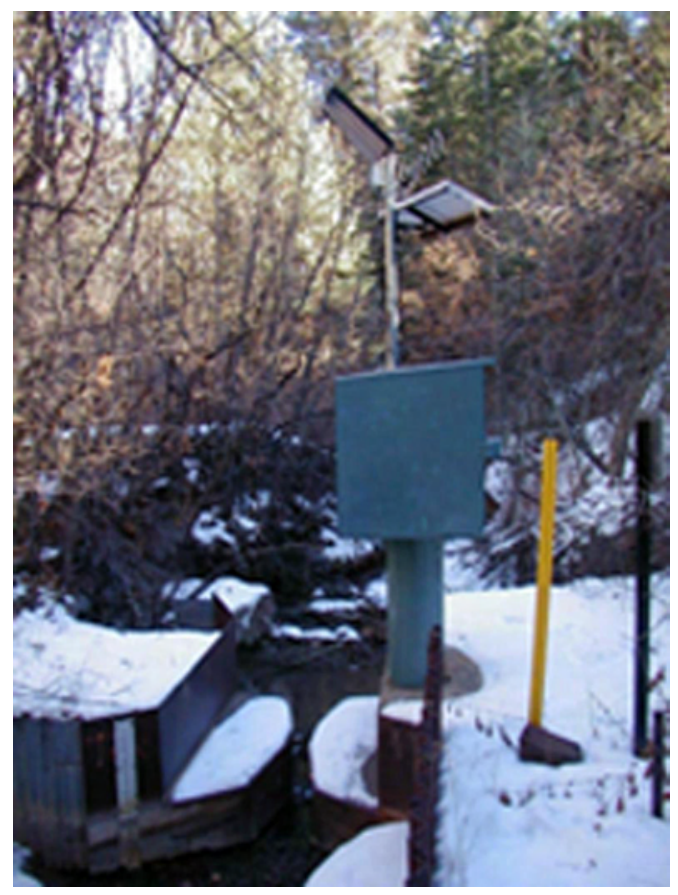




\section{E200 Mortandad below Effuent Canyon \\ Station Analysis \\ 2006 Water Year}

Equipment. Sutron 8210 data logger with cellular phone speech modem with a Design Analysis H-350 lite pressure sensor until August 4, 2003, when a Sutron bubbler was installed in metal half-length shelter over 24" CMP well on right bank. The gaging station is also equipped with an ISCO pump sampler that is trigger by the data logger in a $4^{\prime} \times 4^{\prime}$ metal box. No provision for measurements above wading stage. The reference gage is a reference point on top of flume, and also an outside staff is available.

Field Work. The station was visited fourteen times for the purpose of making a discharge measurement and/or servicing the instrumentation. Field inspections for the gage are listed under site history files on the Hydstra database. Discharge measurements for the gage are listed under site gauging files on the Hydstra database.

Datum Correction. None from levels.

Gage-Height Record. The 8210 data logger record was complete and satisfactory for the water year except for all or part of the following periods, December 6 to February 26, when bubbler orifice was silted or frozen.

Rating. The channel at the gage is about 33 feet wide and straight for about 50 feet upstream and straight for about 75 feet below gage. The streambed is sand and gravel and subject to fill behind flume from flow events and gage silting problem from effluent release. Flow is mostly effluent from TA-50 Rad water treatment plant. The control is a fabricated steel flume about 5 inches at the throat.

Rating No. 1, which was developed on measurements made during the years, is still in effect and was used with a variable shift diagram from last measurement made at gaging station.

During the year, three discharge measurements (No. 26-28), No. 28 being a critical depth computation and thirteen inspections were made.

Discharge. Discharge was computed by applying gage height to Rating No. 1 through shift adjustment based on variable shift diagram. Partial days were computed based on TA-50 release and analysis of precipitation records. Winter period (frozen orifice) was computed using TA-50 discharges. Periods of silted orifice were redrawn on Hydra workbench.

Remarks. Records fair, except for estimated daily discharges, which are poor. 


\section{E200 Mortandad below Effluent Canyon}

Daily Mean Discharge in Cubic Feet per Second

Water Year October 2005 to September 2006

\begin{tabular}{|c|c|c|c|c|c|c|c|c|c|c|c|c|}
\hline DAY & ОСт & NOV & DEC & JAN & FEB & MAR & APR & MAY & JUN & JUL & AUG & SEP \\
\hline 1 & .04 & 0 & 0 & $0^{*}$ & $0^{*}$ & .02 & 0 & .03 & .03 & .02 & .61 & .25 \\
\hline 2 & .02 & 0 & 0 & $0^{*}$ & $.03^{*}$ & .01 & 0 & 0 & 0 & .15 & .22 & .03 \\
\hline 3 & .20 & 0 & 0 & $.03^{*}$ & $0^{*}$ & 0 & .03 & 0 & 0 & .64 & .01 & 0 \\
\hline 4 & .07 & 0 & 0 & $0^{*}$ & $0^{*}$ & 0 & 0 & 0 & 0 & .69 & .01 & 0 \\
\hline 5 & .04 & 0 & .03 & $0^{*}$ & $0^{*}$ & 0 & .06 & 0 & .03 & .78 & .75 & .03 \\
\hline 6 & .02 & 0 & $0^{*}$ & $0^{*}$ & $.03^{*}$ & .04 & .03 & 0 & 0 & .59 & .19 & .14 \\
\hline 7 & .01 & .03 & $0^{*}$ & $0^{*}$ & $0^{*}$ & .01 & .01 & 0 & 0 & .24 & 2.4 & .12 \\
\hline 8 & .01 & 0 & $0^{*}$ & $0^{*}$ & $.03^{*}$ & .03 & 0 & .03 & .03 & .33 & 2.9 & .08 \\
\hline 9 & .07 & 0 & $0^{*}$ & $.03^{*}$ & $0^{*}$ & 0 & 0 & 0 & 0 & 2.0 & .79 & .03 \\
\hline 10 & .09 & 0 & $0^{*}$ & $0^{*}$ & $0^{*}$ & 0 & 0 & 0 & 0 & .83 & .62 & .01 \\
\hline 11 & .05 & 0 & $0^{*}$ & $0^{*}$ & $0^{*}$ & 0 & 0 & 0 & 0 & .30 & .36 & .04 \\
\hline 12 & .03 & 0 & $.03^{*}$ & $0^{*}$ & $0^{*}$ & 0 & .03 & 0 & .03 & .04 & .02 & .04 \\
\hline 13 & .01 & 0 & $0^{*}$ & $0^{*}$ & $.03^{*}$ & .03 & 0 & 0 & 0 & 0 & .12 & .03 \\
\hline 14 & .03 & .03 & $0^{*}$ & $0^{*}$ & $0^{*}$ & 0 & 0 & 0 & .03 & 0 & .79 & 0 \\
\hline 15 & .10 & .03 & $0^{*}$ & $0^{*}$ & $0^{*}$ & 0 & 0 & .03 & 0 & 0 & .49 & 0 \\
\hline 16 & .02 & 0 & $.03^{*}$ & $0^{*}$ & $0^{*}$ & .03 & 0 & 0 & 0 & 0 & 0 & 0 \\
\hline 17 & .04 & .03 & $0^{*}$ & $.03^{*}$ & $0^{*}$ & 0 & .03 & .03 & 0 & 0 & 0 & 0 \\
\hline 18 & .02 & .03 & $.03^{*}$ & $.03^{*}$ & $0^{*}$ & 0 & 0 & 0 & 0 & 0 & 0 & .03 \\
\hline 19 & .09 & 0 & $.03^{*}$ & $0^{*}$ & $0^{*}$ & 0 & 0 & 0 & .03 & 0 & .36 & .03 \\
\hline 20 & .04 & 0 & $.03^{*}$ & $.03^{*}$ & $0^{*}$ & 0 & 0 & 0 & .03 & 0 & .09 & .02 \\
\hline 21 & 0 & 0 & $0^{*}$ & $0^{*}$ & $.03^{*}$ & .03 & .03 & 0 & 0 & 0 & .32 & 0 \\
\hline 22 & 0 & 0 & $.03^{*}$ & $0^{*}$ & $0^{*}$ & .01 & 0 & .03 & .08 & 0 & .01 & 0 \\
\hline 23 & 0 & 0 & $0^{*}$ & $.03^{*}$ & $.03^{*}$ & .03 & 0 & 0 & 0 & 0 & 0 & 0 \\
\hline 24 & .03 & 0 & $0^{*}$ & $0^{*}$ & $0^{*}$ & 0 & .03 & .03 & 0 & 0 & 0 & 0 \\
\hline 25 & 0 & 0 & $0^{*}$ & $.03^{*}$ & $0^{*}$ & 0 & 0 & .03 & 0 & 0 & 14 & .03 \\
\hline 26 & .03 & 0 & $0^{*}$ & $0^{*}$ & 0 & 0 & 0 & 0 & .03 & .03 & 1.2 & .03 \\
\hline 27 & 0 & 0 & $0^{*}$ & $0^{*}$ & 0 & .03 & 0 & 0 & 0 & 0 & .85 & 0 \\
\hline 28 & 0 & .03 & $0^{*}$ & $0^{*}$ & .05 & .01 & 0 & 0 & 0 & .06 & .85 & 0 \\
\hline 29 & 0 & 0 & $0^{*}$ & $0^{*}$ & ----- & 0 & 0 & 0 & 1.9 & 0 & 2.3 & 0 \\
\hline 30 & 0 & .03 & $0^{*}$ & $.03^{*}$ & ----- & 0 & 0 & .03 & .65 & 0 & .17 & 0 \\
\hline 31 & .03 & --.-- & $0^{*}$ & $0^{*}$ & ---נ--ני & 0 & - & 0 & ------ & 0 & .09 & ------ \\
\hline Total & 1.09 & 0.21 & 0.21 & 0.24 & 0.23 & 0.28 & 0.25 & 0.24 & 2.87 & 6.70 & 30.52 & 0.94 \\
\hline Mean & .035 & .007 & .007 & .008 & .008 & .009 & .008 & .008 & .096 & .22 & .98 & .031 \\
\hline Max & .20 & .03 & .03 & .03 & .05 & .04 & .06 & .03 & 1.9 & 2.0 & 14 & .25 \\
\hline Min & 0 & 0 & 0 & 0 & 0 & 0 & 0 & 0 & 0 & 0 & 0 & 0 \\
\hline Acre-Ft & 2.2 & .42 & .42 & .48 & .46 & .56 & .50 & .48 & 5.7 & 13 & 61 & 1.9 \\
\hline Wtr Year & 2006 & Tota & 43.78 & $\mathrm{Me}$ & & & lax & & Min & 0 & Acre-Ft & 87 \\
\hline Cal Year & 2005 & Tota & 31.38 & $\mathrm{Me}$ & & & $\operatorname{lax}$ & 8 & Min & 0 & Acre-Ft & 62 \\
\hline
\end{tabular}

* Estimated 


\section{E2015 Ten Site above Mortandad}

Location. Lat. 3551'38", long. 106¹6'30", NW 1/4, SE 1/4, sec .23, T 19 N., R. 6 E., Los Alamos County, on left bank 0.25 mile upstream from E202, and 2.8 miles upstream from SR 4.

Drainage Area. $0.32 \mathrm{mi}^{2}$.

Period of Record. October 2000 to September 30, 2006.

Revised record. Drainage Area (this report).

Gage. Data logger with cellular telemetry and $90^{\circ}$ sharp-crested weir. Elevation of gage is 6,858 ft above NGVD from GIS 9.1.

Remarks. Water discharge records good except for estimated daily discharges, which are poor.

Extremes for Period of Record. Maximum discharge $303 \mathrm{ft}^{3} / \mathrm{s}$ August 25, 2006, gage height $4.60 \mathrm{ft}$. (from slope-area measurement of peak flow). No flow most of time.

Extremes for Current Year. Maximum discharge $303 \mathrm{ft}^{3} / \mathrm{s}$ at $1255 \mathrm{~h}$, August 25, gage height $4.60 \mathrm{ft}$.(from slope-area measurement of peak flow). No flow most of time.

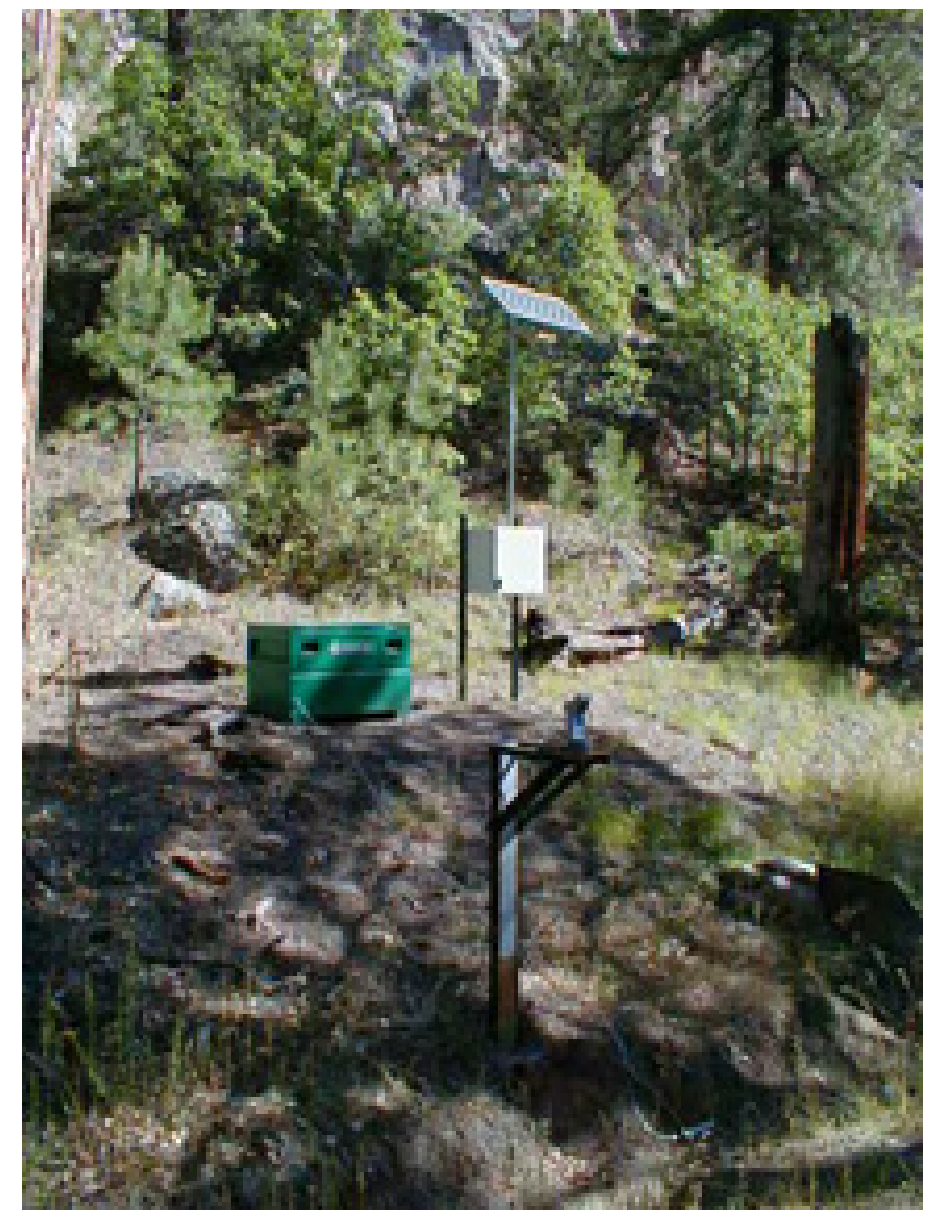




\section{E2015 Ten Site above Mortandad \\ Station Analysis \\ 2006 Water Year}

Equipment. Sutron 8210 data logger (5-min. interval) with cellular phone and speech modem housed in a NEMA shelter on left bank. The stage sensor is a milltronics sonic probe mounted on a 6" channel on left bank unit May 12, 2005, when a Sutron bubbler was installed. The gaging station is also equipped with an ISCO pump sampler for water quality collection in a $4^{\prime} \times 4^{\prime}$ metal box. An outside staff is available for reference. No provisions are made for measurement above wading stage.

Field Work. The station was visited fifteen times for the purpose of making a discharge measurement and/or servicing the instrumentation. Field inspections for the gage are listed under site history files on the Hydstra database. Discharge measurements for the gage are listed under site gauging files on the Hydstra database.

Datum Correction. None. Level run on May 12, 2005, and November 17, 2005, found the gage to be $0.05 \mathrm{ft}$ higher. A datum correction of 0.05 was added from May 12 till outside staff is reset to correct datum. Gage destroyed due to flood on August 25, 2006. Bubbler outlet reset to gage datum of $1.33 \mathrm{ft}$.

Gage-Height Record. The data logger reference to the outside staff gave a complete and satisfactory record.

Rating. The channel is about 8 feet wide and straight for about 60 feet upstream and straight for about 30 feet downstream. The streambed through this reach is primarily sand with gravel.

Rating No. 2 is based on a theoretical computation for 90 degree sharp crested weir, and one critical depth computation of peak flow of $4.60 \mathrm{ft}$ gage height.

Discharge. Computed from Rating No. 2 with zero shifts for the entire year. Discharges were estimated from field notes and weather record.

Fifteen inspections and one critical depth computation of no flow were made during the water year.

Remark: Records good. 


\section{E2015 Ten Site above Mortandad}

Daily Mean Discharge in Cubic Feet per Second

Water Year October 2005 to September 2006

\begin{tabular}{|c|c|c|c|c|c|c|c|c|c|c|c|c|}
\hline DAY & ОСТ & NOV & DEC & JAN & FEB & MAR & APR & MAY & JUN & JUL & AUG & SEP \\
\hline 1 & 0 & 0 & 0 & 0 & 0 & 0 & 0 & 0 & 0 & 0 & 0 & $.14^{*}$ \\
\hline 2 & 0 & 0 & 0 & 0 & 0 & 0 & 0 & 0 & 0 & 0 & 0 & $0^{*}$ \\
\hline 3 & 0 & 0 & 0 & 0 & 0 & 0 & 0 & 0 & 0 & 0 & 0 & $0^{*}$ \\
\hline 4 & 0 & 0 & 0 & 0 & 0 & 0 & 0 & 0 & 0 & 0 & 0 & $0^{*}$ \\
\hline 5 & 0 & 0 & 0 & 0 & 0 & 0 & 0 & 0 & 0 & 0 & 0 & $0^{*}$ \\
\hline 6 & 0 & 0 & 0 & 0 & 0 & 0 & 0 & 0 & 0 & 0 & 0 & $0^{*}$ \\
\hline 7 & 0 & 0 & 0 & 0 & 0 & 0 & 0 & 0 & 0 & 0 & 0 & $0^{*}$ \\
\hline 8 & 0 & 0 & 0 & 0 & 0 & 0 & 0 & 0 & 0 & 0 & 0 & $0^{*}$ \\
\hline 9 & 0 & 0 & 0 & 0 & 0 & 0 & 0 & 0 & 0 & 0 & 0 & $0^{*}$ \\
\hline 10 & 0 & 0 & 0 & 0 & 0 & 0 & 0 & 0 & 0 & 0 & 0 & $0^{*}$ \\
\hline 11 & 0 & 0 & 0 & 0 & 0 & 0 & 0 & 0 & 0 & 0 & 0 & $0^{*}$ \\
\hline 12 & 0 & 0 & 0 & 0 & 0 & 0 & 0 & 0 & 0 & 0 & 0 & $0^{*}$ \\
\hline 13 & 0 & 0 & 0 & 0 & 0 & 0 & 0 & 0 & 0 & 0 & 0 & $0^{*}$ \\
\hline 14 & 0 & 0 & 0 & 0 & 0 & 0 & 0 & 0 & 0 & 0 & 0 & $0^{*}$ \\
\hline 15 & 0 & 0 & 0 & 0 & 0 & 0 & 0 & 0 & 0 & 0 & 0 & $0^{*}$ \\
\hline 16 & 0 & 0 & 0 & 0 & 0 & 0 & 0 & 0 & 0 & 0 & 0 & $0^{*}$ \\
\hline 17 & 0 & 0 & 0 & 0 & 0 & 0 & 0 & 0 & 0 & 0 & 0 & $0^{*}$ \\
\hline 18 & 0 & 0 & 0 & 0 & 0 & 0 & 0 & 0 & 0 & 0 & 0 & $0^{*}$ \\
\hline 19 & 0 & 0 & 0 & 0 & 0 & 0 & 0 & 0 & 0 & 0 & 0 & $0^{*}$ \\
\hline 20 & 0 & 0 & 0 & 0 & 0 & 0 & 0 & 0 & 0 & 0 & 0 & $0^{*}$ \\
\hline 21 & 0 & 0 & 0 & 0 & 0 & 0 & 0 & 0 & 0 & 0 & 0 & $0^{*}$ \\
\hline 22 & 0 & 0 & 0 & 0 & 0 & 0 & 0 & 0 & 0 & 0 & 0 & $0^{*}$ \\
\hline 23 & 0 & 0 & 0 & 0 & 0 & 0 & 0 & 0 & 0 & 0 & 0 & $0^{*}$ \\
\hline 24 & 0 & 0 & 0 & 0 & 0 & 0 & 0 & 0 & 0 & 0 & 0 & $0^{*}$ \\
\hline 25 & 0 & 0 & 0 & 0 & 0 & 0 & 0 & 0 & 0 & 0 & $5.5^{\star}$ & $0^{*}$ \\
\hline 26 & 0 & 0 & 0 & 0 & 0 & 0 & 0 & 0 & 0 & 0 & $0^{*}$ & $0^{*}$ \\
\hline 27 & 0 & 0 & 0 & 0 & 0 & 0 & 0 & 0 & 0 & 0 & $0^{*}$ & $0^{*}$ \\
\hline 28 & 0 & 0 & 0 & 0 & 0 & 0 & 0 & 0 & 0 & 0 & $0^{*}$ & $0^{*}$ \\
\hline 29 & 0 & 0 & 0 & 0 & ----- & 0 & 0 & 0 & 0 & 0 & $0^{*}$ & $0^{*}$ \\
\hline 30 & 0 & 0 & 0 & 0 & ----- & 0 & 0 & 0 & 0 & 0 & $0^{*}$ & $0^{*}$ \\
\hline 31 & 0 & -.--- & 0 & 0 & -.--- & 0 & --.-- & 0 & -.--- & 0 & $0^{*}$ & -..-. \\
\hline Total & 0 & 0 & 0 & 0 & 0 & 0 & 0 & 0 & 0 & 0 & 5.5 & 0.14 \\
\hline Mean & 0 & 0 & 0 & 0 & 0 & 0 & 0 & 0 & 0 & 0 & .18 & .005 \\
\hline $\operatorname{Max}$ & 0 & 0 & 0 & 0 & 0 & 0 & 0 & 0 & 0 & 0 & 5.5 & .14 \\
\hline Min & 0 & 0 & 0 & 0 & 0 & 0 & 0 & 0 & 0 & 0 & 0 & 0 \\
\hline Acre-Ft & 0 & 0 & 0 & 0 & 0 & 0 & 0 & 0 & 0 & 0 & 11 & .28 \\
\hline Wtr Year & 2006 & Total & 5.64 & Mear & .015 & & Max & 5.5 & Min & 0 & Acre-Ft & 11 \\
\hline Cal Year & 2005 & Total & 1.81 & Mear & .005 & & $\operatorname{Max}$ & .75 & Min & 0 & Acre-Ft & 3.6 \\
\hline
\end{tabular}




\section{E202 Mortandad above Sediment Traps}

Location. Lat 3551'39", long 106²16'15", NE 1/4 SW 1/4 sec. 23, T. 19 N, R. 6 E, Los Alamos County, 4.3 miles upstream from SR 4.

Drainage Area. $1.14 \mathrm{mi}^{2}$.

Period of Record. October 1, 1997, to September 30, 2006.

Gage. Data logger with cellular telemetry and 2.5-ft Parshall flume. Elevation of gage is 6,833 ft above NGVD from GIS 9.1.

Remarks. Water discharge records fair, except for periods of estimated records, which are poor.

Average Discharge. $10 \mathrm{yr}, 0.002 \mathrm{ft}^{3} / \mathrm{s}, 1.4$ acre- $\mathrm{ft} / \mathrm{yr}$.

Extremes for Period of Record. Maximum discharge $292 \mathrm{ft}^{3} / \mathrm{s}$, gage height unknown, August 25, 2006 (from critical depth computation of peak flow). No flow most of time.

Extremes for Current Water Year. Maximum discharge $292 \mathrm{ft}^{3} / \mathrm{s}$, at unknown hour, gage height unknown, August 25 (from critical depth computation of peak flow). No flow most of time.

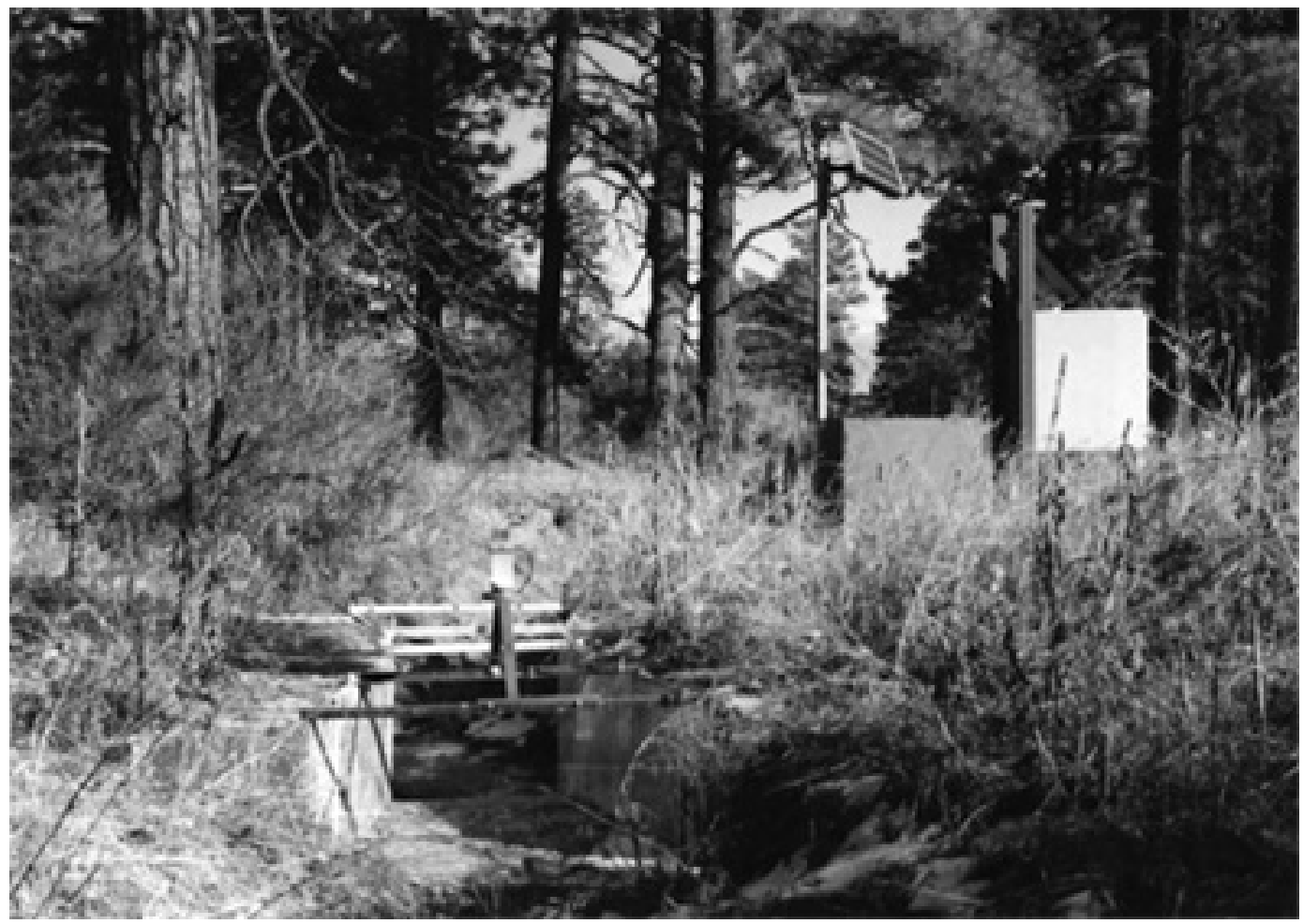




\section{E202 Mortandad above Sediment Traps \\ Station Analysis \\ 2006 Water Year}

Equipment. Sutron 8210 data logger (5-min. interval) with solar charging system and a milltronics sonic probe sensor mounted on 2.5 feet Parshall flume. ISCO sampler housed in separate shelter is stage triggered by data logger.

Field Work. The station was visited sixteen times for the purpose of making a discharge measurement and/or servicing the instrumentation. Field inspections for the gage are listed under site history files on the Hydstra database. Discharge measurements for the gage are listed under site gauging files on the Hydstra database.

Datum Correction. None

\section{Gage-Height Record. None lost.}

Rating. Two-foot Parshall flume is channeled and should be large enough to contain most flows. Approach and escape sections are spread due to overgrowth and debris in channel.

During the water year sixteen inspections of no flow were made. One critical depth computation was made up stream, below E201, on August 25.

Discharge. Discharge was computed directly using Rating No. 1.

Flows contained within flume were computed from Rating 1. Flood of August 25 had a peak discharge of 292 cfs from critical depth computation done upstream. This number is probably $\pm 15 \%$. Most of this water bypassed the gage because "obviously" the flume could not handle it. This peak cannot be used in accordance with the gage height.

A critical depth computation was conducted downstream of E201 for the peak flow on August 25. A total of $292 \mathrm{cfs}$ flowed through and around gage at E201, but due to configuration of stream bed leading into E202, only an estimated discharge flowed through the flume with an estimated difference of $254 \mathrm{cfs}$ flowing around the flume.

Remarks. Records good. 


\section{E202 Mortandad above Sediment Traps}

Daily Mean Discharge in Cubic Feet per Second

Water Year October 2005 to September 2006

\begin{tabular}{|c|c|c|c|c|c|c|c|c|c|c|c|c|}
\hline DAY & OCT & NOV & DEC & JAN & FEB & MAR & APR & MAY & JUN & JUL & AUG & SEP \\
\hline 1 & 0 & 0 & 0 & 0 & 0 & 0 & 0 & 0 & 0 & 0 & .01 & 0 \\
\hline 2 & 0 & 0 & 0 & 0 & 0 & 0 & 0 & 0 & 0 & 0 & 0 & 0 \\
\hline 3 & 0 & 0 & 0 & 0 & 0 & 0 & 0 & 0 & 0 & 0 & 0 & 0 \\
\hline 4 & 0 & 0 & 0 & 0 & 0 & 0 & 0 & 0 & 0 & 0 & 0 & 0 \\
\hline 5 & 0 & 0 & 0 & 0 & 0 & 0 & 0 & 0 & 0 & 0 & 0 & 0 \\
\hline 6 & 0 & 0 & 0 & 0 & 0 & 0 & 0 & 0 & 0 & 0 & 0 & 0 \\
\hline 7 & 0 & 0 & 0 & 0 & 0 & 0 & 0 & 0 & 0 & 0 & .05 & 0 \\
\hline 8 & 0 & 0 & 0 & 0 & 0 & 0 & 0 & 0 & 0 & 0 & .20 & 0 \\
\hline 9 & 0 & 0 & 0 & 0 & 0 & 0 & 0 & 0 & 0 & .05 & 0 & 0 \\
\hline 10 & 0 & 0 & 0 & 0 & 0 & 0 & 0 & 0 & 0 & 0 & 0 & 0 \\
\hline 11 & 0 & 0 & 0 & 0 & 0 & 0 & 0 & 0 & 0 & 0 & 0 & 0 \\
\hline 12 & 0 & 0 & 0 & 0 & 0 & 0 & 0 & 0 & 0 & 0 & 0 & 0 \\
\hline 13 & 0 & 0 & 0 & 0 & 0 & 0 & 0 & 0 & 0 & 0 & 0 & 0 \\
\hline 14 & 0 & 0 & 0 & 0 & 0 & 0 & 0 & 0 & 0 & 0 & 0 & 0 \\
\hline 15 & 0 & 0 & 0 & 0 & 0 & 0 & 0 & 0 & 0 & 0 & 0 & 0 \\
\hline 16 & 0 & 0 & 0 & 0 & 0 & 0 & 0 & 0 & 0 & 0 & 0 & 0 \\
\hline 17 & 0 & 0 & 0 & 0 & 0 & 0 & 0 & 0 & 0 & 0 & 0 & 0 \\
\hline 18 & 0 & 0 & 0 & 0 & 0 & 0 & 0 & 0 & 0 & 0 & 0 & 0 \\
\hline 19 & 0 & 0 & 0 & 0 & 0 & 0 & 0 & 0 & 0 & 0 & 0 & 0 \\
\hline 20 & 0 & 0 & 0 & 0 & 0 & 0 & 0 & 0 & 0 & 0 & 0 & 0 \\
\hline 21 & 0 & 0 & 0 & 0 & 0 & 0 & 0 & 0 & 0 & 0 & 0 & 0 \\
\hline 22 & 0 & 0 & 0 & 0 & 0 & 0 & 0 & 0 & 0 & 0 & 0 & 0 \\
\hline 23 & 0 & 0 & 0 & 0 & 0 & 0 & 0 & 0 & 0 & 0 & 0 & 0 \\
\hline 24 & 0 & 0 & 0 & 0 & 0 & 0 & 0 & 0 & 0 & 0 & 0 & 0 \\
\hline 25 & 0 & 0 & 0 & 0 & 0 & 0 & 0 & 0 & 0 & 0 & 5.6 & 0 \\
\hline 26 & 0 & 0 & 0 & .04 & 0 & 0 & 0 & 0 & 0 & 0 & .06 & 0 \\
\hline 27 & 0 & 0 & 0 & 0 & 0 & 0 & 0 & 0 & 0 & 0 & 0 & 0 \\
\hline 28 & 0 & 0 & 0 & 0 & 0 & 0 & 0 & 0 & 0 & 0 & 0 & 0 \\
\hline 29 & 0 & 0 & 0 & 0 & ----- & 0 & 0 & 0 & .18 & 0 & 0 & 0 \\
\hline 30 & 0 & 0 & 0 & 0 & ----- & 0 & 0 & 0 & 0 & 0 & 0 & 0 \\
\hline 31 & 0 & ------ & 0 & 0 & ------ & 0 & ------ & 0 & ----- & 0 & 0 & ----- \\
\hline Total & 0 & 0 & 0 & 0.04 & 0 & 0 & 0 & 0 & 0.18 & 0.05 & 5.92 & 0 \\
\hline Mean & 0 & 0 & 0 & .001 & 0 & 0 & 0 & 0 & .006 & .002 & .19 & 0 \\
\hline $\operatorname{Max}$ & 0 & 0 & 0 & .04 & 0 & 0 & 0 & 0 & .18 & .05 & 5.6 & 0 \\
\hline Min & 0 & 0 & 0 & 0 & 0 & 0 & 0 & 0 & 0 & 0 & 0 & 0 \\
\hline Acre-Ft & 0 & 0 & 0 & .08 & 0 & 0 & 0 & 0 & .36 & .10 & 12 & 0 \\
\hline Wtr Year & 2006 & Total & 6.19 & Mean & .017 & & Max & 5.6 & Min & 0 & Acre-Ft & 12 \\
\hline Cal Year & 2005 & Total & 2.05 & Mean & .006 & & Max & 1.7 & Min & 0 & Acre-Ft & 4.1 \\
\hline
\end{tabular}




\section{E203 Mortandad below Sediment Traps}

Location. Lat. 3551'39", long. 106¹6'6", NE 1/4 SW 1/4 sec. 23, T. 19 N, R. 6 E, Los Alamos County, at exit from sediment collection traps, 4.2 miles upstream from SR 4.

Drainage Area. $1.17 \mathrm{mi}^{2}$.

Period of Record. October 1, 1996, to August 25, 2006 (destroyed by flood).

Revised Record. Drainage Area (this report).

Gage. Data logger and 6-in. Parshall flume. Elevation of gage is 6,817 ft above NGVD from GIS 9.1.

Remarks. Records good, except for estimated daily discharges, which are poor.

Average Discharge. $10 \mathrm{yr}, 0.002 \mathrm{ft}^{3} / \mathrm{s}, 1.4$ acre $\mathrm{ft} / \mathrm{yr}$.

Extremes for Period of Record. Maximum discharge, $220 \mathrm{ft}^{3} / \mathrm{s}$, August 25, 2006 (from critical depth computation), gage height unknown. No flow most of the time.

Extremes for Current Water Year. Maximum discharge $220 \mathrm{ft}^{3} / \mathrm{s}$, August 25, from critical depth computation, gage height unknown. No flow most of time.

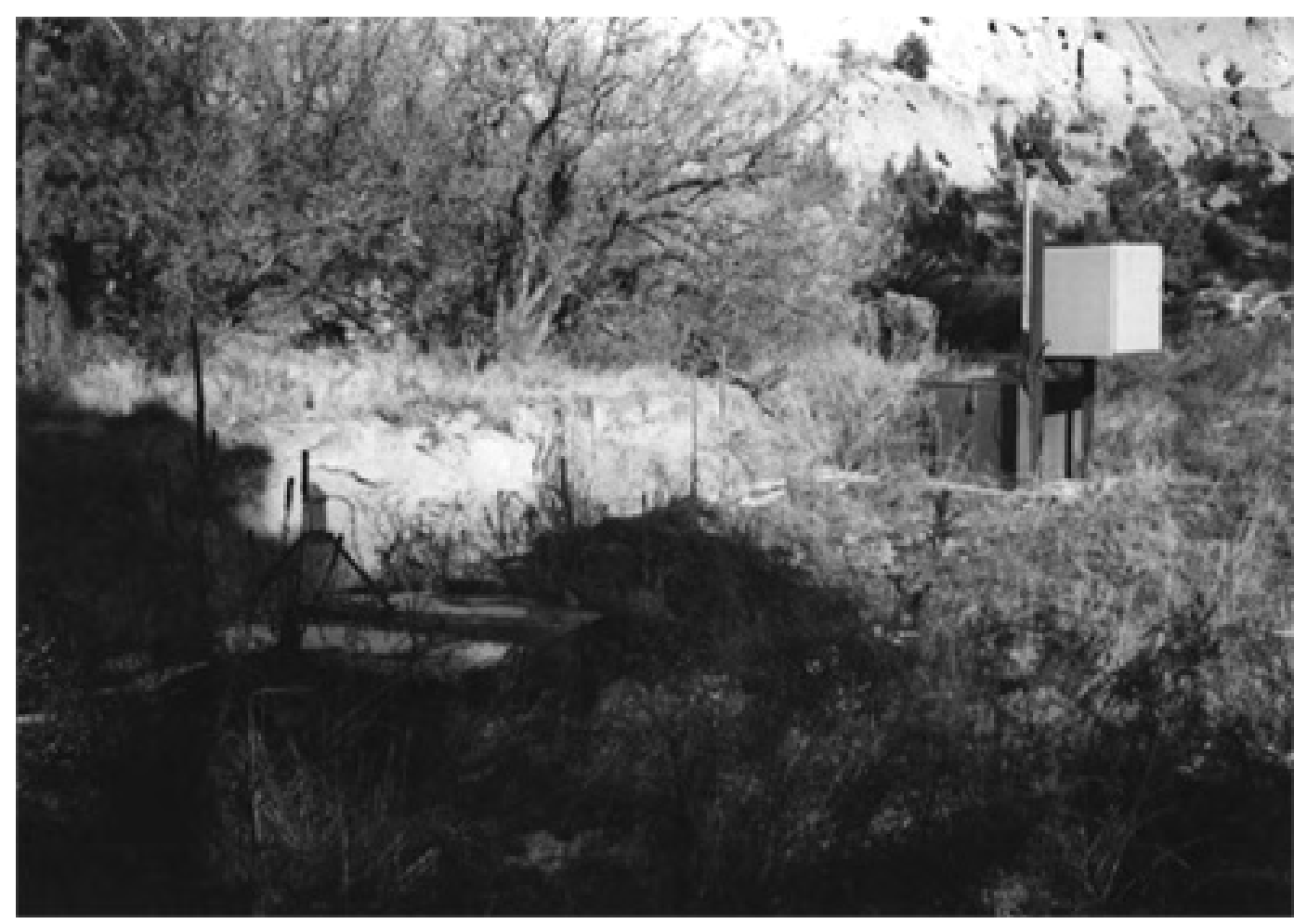




\section{E203 Mortandad below Sediment Traps \\ Station Analysis \\ 2006 Water Year}

Equipment. Sutron 8200 data logger (05 min. interval) with no telemetry. The stage sensor is a milltronics sonic probe mounted on a 6" parshall flume south of sediment collection trap. The station is also equipped with ISCO pump sampler which is housed in a $4 \times 4$ metal box on south bank and is triggered by the data logger. All the equipment is powered with a solar panel battery charging system. The outside staff in flume is the reference gage.

Field Work. The station was visited fifteen times for the purpose of making a discharge measurement and/or servicing the instrumentation. Field inspections for the gage are listed under site history files on the Hydstra database. Discharge measurements for the gage are listed under site gauging files on the Hydstra database.

Datum Correction. None.

Gage-Height Record. The data logger referenced to the outside staff gave a complete and satisfactory record for the year, excluding gage height for August 25 when gage was washed out.

Rating. Six-inch Parshall flume mounted at most downstream sediment traps. Record should be excellent if there is ever flow.

Fifteen inspections of no flow were made this year.

Discharge. Computed from flume rating No. 1. One critical depth computation of one section yielded 220 cfs. This value should be $\pm 20 \%$. Daily flow as calculated by assuming peak flow for one hour and dividing by twenty four.

Remarks. Records good, except for estimated daily discharge which is poor. 


\section{E203 Mortandad below Sediment Traps}

Daily Mean Discharge in Cubic Feet per Second

Water Year October 2005 to September 2006

\begin{tabular}{|c|c|c|c|c|c|c|c|c|c|c|c|c|}
\hline DAY & OCT & NOV & DEC & JAN & FEB & MAR & APR & MAY & JUN & JUL & AUG & SEP \\
\hline 1 & 0 & 0 & 0 & 0 & 0 & 0 & 0 & 0 & 0 & 0 & 0 & $0^{*}$ \\
\hline 2 & 0 & 0 & 0 & 0 & 0 & 0 & 0 & 0 & 0 & 0 & 0 & $0^{*}$ \\
\hline 3 & 0 & 0 & 0 & 0 & 0 & 0 & 0 & 0 & 0 & 0 & 0 & $0^{*}$ \\
\hline 4 & 0 & 0 & 0 & 0 & 0 & 0 & 0 & 0 & 0 & 0 & 0 & $0^{*}$ \\
\hline 5 & 0 & 0 & 0 & 0 & 0 & 0 & 0 & 0 & 0 & 0 & 0 & $0^{*}$ \\
\hline 6 & 0 & 0 & 0 & 0 & 0 & 0 & 0 & 0 & 0 & 0 & 0 & $0^{*}$ \\
\hline 7 & 0 & 0 & 0 & 0 & 0 & 0 & 0 & 0 & 0 & 0 & 0 & $0^{*}$ \\
\hline 8 & 0 & 0 & 0 & 0 & 0 & 0 & 0 & 0 & 0 & 0 & 0 & $0^{*}$ \\
\hline 9 & 0 & 0 & 0 & 0 & 0 & 0 & 0 & 0 & 0 & 0 & 0 & $0^{*}$ \\
\hline 10 & 0 & 0 & 0 & 0 & 0 & 0 & 0 & 0 & 0 & 0 & 0 & $0^{*}$ \\
\hline 11 & 0 & 0 & 0 & 0 & 0 & 0 & 0 & 0 & 0 & 0 & 0 & $0^{*}$ \\
\hline 12 & 0 & 0 & 0 & 0 & 0 & 0 & 0 & 0 & 0 & 0 & 0 & $0^{*}$ \\
\hline 13 & 0 & 0 & 0 & 0 & 0 & 0 & 0 & 0 & 0 & 0 & 0 & $0^{*}$ \\
\hline 14 & 0 & 0 & 0 & 0 & 0 & 0 & 0 & 0 & 0 & 0 & 0 & $0^{*}$ \\
\hline 15 & 0 & 0 & 0 & 0 & 0 & 0 & 0 & 0 & 0 & 0 & 0 & $0^{*}$ \\
\hline 16 & 0 & 0 & 0 & 0 & 0 & 0 & 0 & 0 & 0 & 0 & 0 & $0^{*}$ \\
\hline 17 & 0 & 0 & 0 & 0 & 0 & 0 & 0 & 0 & 0 & 0 & 0 & $0^{*}$ \\
\hline 18 & 0 & 0 & 0 & 0 & 0 & 0 & 0 & 0 & 0 & 0 & 0 & $0^{*}$ \\
\hline 19 & 0 & 0 & 0 & 0 & 0 & 0 & 0 & 0 & 0 & 0 & 0 & $0^{*}$ \\
\hline 20 & 0 & 0 & 0 & 0 & 0 & 0 & 0 & 0 & 0 & 0 & 0 & $0^{*}$ \\
\hline 21 & 0 & 0 & 0 & 0 & 0 & 0 & 0 & 0 & 0 & 0 & 0 & $0^{*}$ \\
\hline 22 & 0 & 0 & 0 & 0 & 0 & 0 & 0 & 0 & 0 & 0 & 0 & $0^{*}$ \\
\hline 23 & 0 & 0 & 0 & 0 & 0 & 0 & 0 & 0 & 0 & 0 & 0 & $0^{*}$ \\
\hline 24 & 0 & 0 & 0 & 0 & 0 & 0 & 0 & 0 & 0 & 0 & 0 & $0^{*}$ \\
\hline 25 & 0 & 0 & 0 & 0 & 0 & 0 & 0 & 0 & 0 & 0 & $9.2^{*}$ & $0^{*}$ \\
\hline 26 & 0 & 0 & 0 & 0 & 0 & 0 & 0 & 0 & 0 & 0 & $0^{*}$ & $0^{*}$ \\
\hline 27 & 0 & 0 & 0 & 0 & 0 & 0 & 0 & 0 & 0 & 0 & $0^{*}$ & $0^{*}$ \\
\hline 28 & 0 & 0 & 0 & 0 & 0 & 0 & 0 & 0 & 0 & 0 & $0^{*}$ & $0^{*}$ \\
\hline 29 & 0 & 0 & 0 & 0 & ----- & 0 & 0 & 0 & 0 & 0 & $0^{*}$ & $0^{*}$ \\
\hline 30 & 0 & 0 & 0 & 0 & ----- & 0 & 0 & 0 & 0 & 0 & $0^{*}$ & $0^{*}$ \\
\hline 31 & 0 & ----- & 0 & 0 & ----- & 0 & ---- & 0 & ---- & 0 & $0^{*}$ & ----- \\
\hline Total & 0 & 0 & 0 & 0 & 0 & 0 & 0 & 0 & 0 & 0 & 9.2 & 0 \\
\hline Mean & 0 & 0 & 0 & 0 & 0 & 0 & 0 & 0 & 0 & 0 & .30 & 0 \\
\hline Max & 0 & 0 & 0 & 0 & 0 & 0 & 0 & 0 & 0 & 0 & 9.2 & 0 \\
\hline Min & 0 & 0 & 0 & 0 & 0 & 0 & 0 & 0 & 0 & 0 & 0 & 0 \\
\hline Acre-Ft & 0 & 0 & 0 & 0 & 0 & 0 & 0 & 0 & 0 & 0 & 18 & 0 \\
\hline Wtr Year & 2006 & Total & 9.2 & Mean & .025 & & Max & 9.2 & Min & 0 & Acre-Ft & 18 \\
\hline Cal Year & 2005 & Total & 1.2 & Mean & .003 & & $\operatorname{Max}$ & 1.2 & Min & 0 & Acre-Ft & 2.4 \\
\hline
\end{tabular}

* Estimated 


\section{E204 Mortandad at LANL Boundary}

Location. Lat. $35^{\circ} 51^{\prime} 21^{\prime \prime}$, long. $106^{\circ} 14^{\prime} 43^{\prime \prime}$, NW 1/4 sec. 30, T. 19, R. 7 E, Santa Fe County, $100 \mathrm{ft}$ upstream from LANL/San Ildefonso Indian Reservation Boundary, and 2.8 miles upstream from SR 4.

Drainage Area. $1.61 \mathrm{mi}^{2}$.

Period of Record. October 1, 1993, to September 30, 2006.

Revised Record. Drainage Area (this report).

Gage. Data logger with cellular telemetry and concrete control. Elevation of gage is $6,651 \mathrm{ft}$ above NGVD from GIS 9.1.

Remarks. Records good.

Average Discharge. 13 yr, zero.

Extremes for Period of Record. No flow for period.

Extremes for Current Water Year. No flow for year.

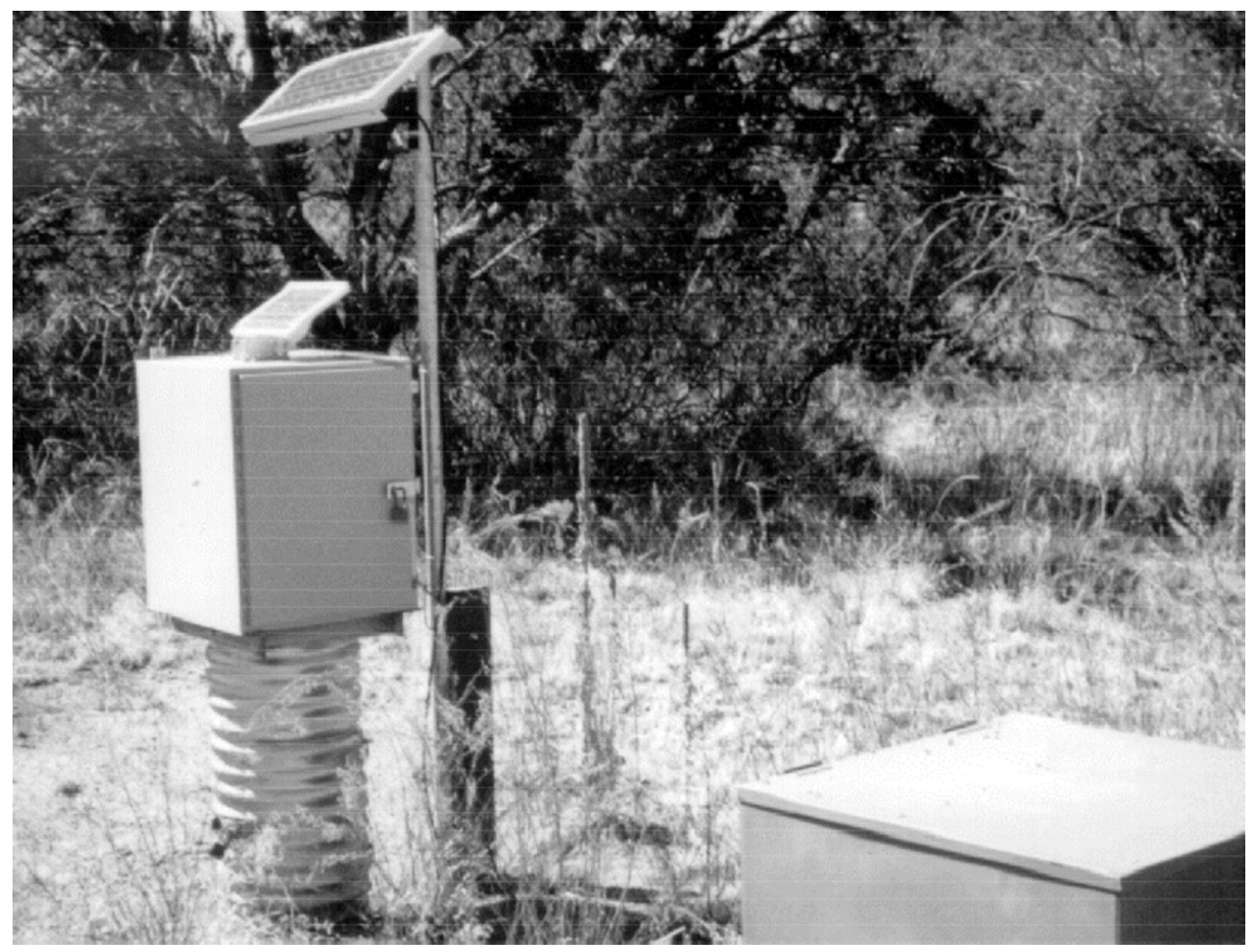




\section{E204 Mortandad at LANL Boundary \\ Station Analysis \\ 2006 Water Year}

Equipment. Sutron 8210 data logger (5-min. interval) with a solar charging system and a milltronics sonic probe sensor mounted on 2.5 feet Parshall flume. ISCO sampler housed in separate shelter is stage triggered by data logger. No provision for measurements above wading stages.

Field Work. The station was visited twelve times for the purpose of making a discharge measurement and/or servicing the instrumentation. Field inspections for the gage are listed under site history files on the Hydstra database. Discharge measurements for the gage are listed under site gauging files on the Hydstra database.

Datum Correction. None. Levels run November 13, 2005, showed the gage to be reading with allowable limits.

Gage-Height Record. Complete for year. All below PZF.

Rating. Channel is straight above and below gage for 100 feet. Channel is not well defined and resembles a low grass-covered swale. Flow is "very" infrequent. The control is broad-crested weir 10 feet downstream with $\mathrm{V}$ notch below gage.

No rating has been developed, but PZF is well defined for concrete broad-crested weir.

During the water year, three inspections of no flow were made. No discharge measurement made this year.

Discharge. No flow all year based on all unit values being below PZF.

Remarks. Records good. Twelve inspections of no flow made. 


\section{E204 Mortandad at LANL Boundary}

Daily Mean Discharge in Cubic Feet per Second

Water Year October 2005 to September 2006

\begin{tabular}{|c|c|c|c|c|c|c|c|c|c|c|c|c|}
\hline DAY & OCT & NOV & DEC & JAN & FEB & MAR & APR & MAY & JUN & JUL & AUG & SEP \\
\hline 1 & 0 & 0 & 0 & 0 & 0 & 0 & 0 & 0 & 0 & 0 & 0 & 0 \\
\hline 2 & 0 & 0 & 0 & 0 & 0 & 0 & 0 & 0 & 0 & 0 & 0 & 0 \\
\hline 3 & 0 & 0 & 0 & 0 & 0 & 0 & 0 & 0 & 0 & 0 & 0 & 0 \\
\hline 4 & 0 & 0 & 0 & 0 & 0 & 0 & 0 & 0 & 0 & 0 & 0 & 0 \\
\hline 5 & 0 & 0 & 0 & 0 & 0 & 0 & 0 & 0 & 0 & 0 & 0 & 0 \\
\hline 6 & 0 & 0 & 0 & 0 & 0 & 0 & 0 & 0 & 0 & 0 & 0 & 0 \\
\hline 7 & 0 & 0 & 0 & 0 & 0 & 0 & 0 & 0 & 0 & 0 & 0 & 0 \\
\hline 8 & 0 & 0 & 0 & 0 & 0 & 0 & 0 & 0 & 0 & 0 & 0 & 0 \\
\hline 9 & 0 & 0 & 0 & 0 & 0 & 0 & 0 & 0 & 0 & 0 & 0 & 0 \\
\hline 10 & 0 & 0 & 0 & 0 & 0 & 0 & 0 & 0 & 0 & 0 & 0 & 0 \\
\hline 11 & 0 & 0 & 0 & 0 & 0 & 0 & 0 & 0 & 0 & 0 & 0 & 0 \\
\hline 12 & 0 & 0 & 0 & 0 & 0 & 0 & 0 & 0 & 0 & 0 & 0 & 0 \\
\hline 13 & 0 & 0 & 0 & 0 & 0 & 0 & 0 & 0 & 0 & 0 & 0 & 0 \\
\hline 14 & 0 & 0 & 0 & 0 & 0 & 0 & 0 & 0 & 0 & 0 & 0 & 0 \\
\hline 15 & 0 & 0 & 0 & 0 & 0 & 0 & 0 & 0 & 0 & 0 & 0 & 0 \\
\hline 16 & 0 & 0 & 0 & 0 & 0 & 0 & 0 & 0 & 0 & 0 & 0 & 0 \\
\hline 17 & 0 & 0 & 0 & 0 & 0 & 0 & 0 & 0 & 0 & 0 & 0 & 0 \\
\hline 18 & 0 & 0 & 0 & 0 & 0 & 0 & 0 & 0 & 0 & 0 & 0 & 0 \\
\hline 19 & 0 & 0 & 0 & 0 & 0 & 0 & 0 & 0 & 0 & 0 & 0 & 0 \\
\hline 20 & 0 & 0 & 0 & 0 & 0 & 0 & 0 & 0 & 0 & 0 & 0 & 0 \\
\hline 21 & 0 & 0 & 0 & 0 & 0 & 0 & 0 & 0 & 0 & 0 & 0 & 0 \\
\hline 22 & 0 & 0 & 0 & 0 & 0 & 0 & 0 & 0 & 0 & 0 & 0 & 0 \\
\hline 23 & 0 & 0 & 0 & 0 & 0 & 0 & 0 & 0 & 0 & 0 & 0 & 0 \\
\hline 24 & 0 & 0 & 0 & 0 & 0 & 0 & 0 & 0 & 0 & 0 & 0 & 0 \\
\hline 25 & 0 & 0 & 0 & 0 & 0 & 0 & 0 & 0 & 0 & 0 & 0 & 0 \\
\hline 26 & 0 & 0 & 0 & 0 & 0 & 0 & 0 & 0 & 0 & 0 & 0 & 0 \\
\hline 27 & 0 & 0 & 0 & 0 & 0 & 0 & 0 & 0 & 0 & 0 & 0 & 0 \\
\hline 28 & 0 & 0 & 0 & 0 & 0 & 0 & 0 & 0 & 0 & 0 & 0 & 0 \\
\hline 29 & 0 & 0 & 0 & 0 & ----- & 0 & 0 & 0 & 0 & 0 & 0 & 0 \\
\hline 30 & 0 & 0 & 0 & 0 & ------ & 0 & 0 & 0 & 0 & 0 & 0 & \\
\hline 31 & 0 & ----- & 0 & 0 & ----- & 0 & ------ & 0 & ----- & 0 & 0 & י--.- \\
\hline Total & 0 & 0 & 0 & 0 & 0 & 0 & 0 & 0 & 0 & 0 & 0 & 0 \\
\hline Mean & 0 & 0 & 0 & 0 & 0 & 0 & 0 & 0 & 0 & 0 & 0 & 0 \\
\hline $\operatorname{Max}$ & 0 & 0 & 0 & 0 & 0 & 0 & 0 & 0 & 0 & 0 & 0 & 0 \\
\hline Min & 0 & 0 & 0 & 0 & 0 & 0 & 0 & 0 & 0 & 0 & 0 & 0 \\
\hline Acre-Ft & 0 & 0 & 0 & 0 & 0 & 0 & 0 & 0 & 0 & 0 & 0 & 0 \\
\hline Wtr Year & 2006 & Total & 0 & & 7 & & Max & 0 & Min & 0 & Acre-Ft & 0 \\
\hline Cal Year & 2005 & Total & 0 & $\mathrm{Me}$ & 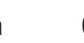 & & Max & 0 & Min & 0 & Acre-Ft & 0 \\
\hline
\end{tabular}




\section{E218 Cañada del Buey near TA-46}

Location. Lat. 35 51'31", long. 106 $17^{\prime} 17^{\prime \prime}$ in 1/4 NE 1/4 SW sec. 26, T. 19 N, R. 6 E in Los Alamos County, on left bank 0.25 mile upstream from east gate of SWSC plant.

Drainage Area. $0.30 \mathrm{mi}^{2}$.

Period of Record. June 1, 2000, to August 25, 2006.(destroyed by flood).

Revised Record. Drainage Area (this report).

Gage. Data logger with cellular telemetry and 2-ft Parshall flume. Elevation of gage is 6,937 ft above NGVD from GIS 9.1.

Remarks. Water discharge records good.

Average Discharge. $6 \mathrm{yr}, 0.02 \mathrm{ft}^{3} / \mathrm{s}, 14$ acre-ft/year.

Extremes for Period of Record. Maximum discharge $228 \mathrm{ft}^{3} / \mathrm{s}$, August 25, 2006, gage height $3.40 \mathrm{ft}$, from critical depth computation of peak flow. No flow most of time.

Extremes for Current Water Year. Maximum discharge $228 \mathrm{ft}^{3} / \mathrm{s}$ at unknown hour, August 25, gage height $3.40 \mathrm{ft}$. from critical depth computation of peak flow. No flow most of time.

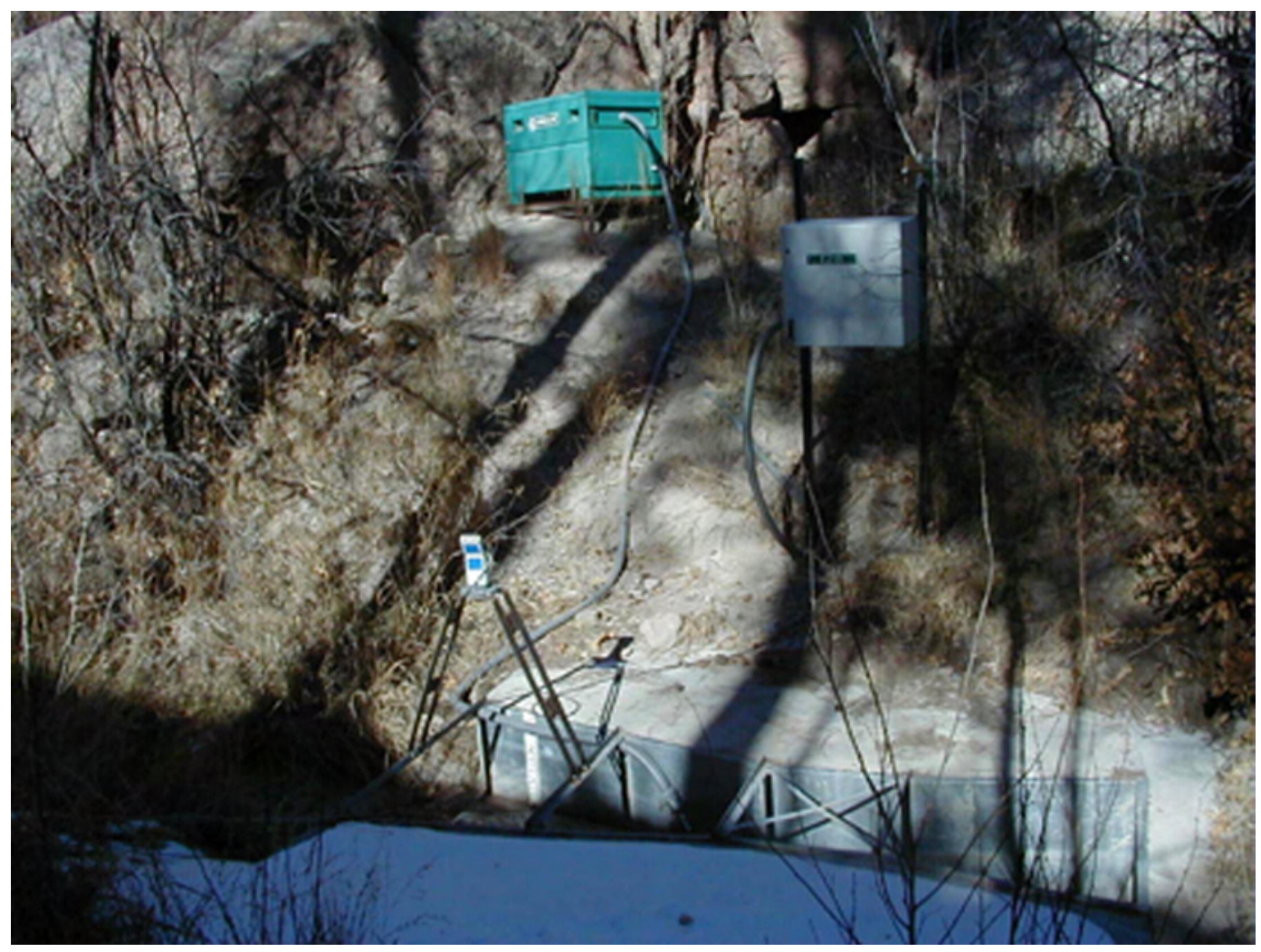




\section{E218 Cañada del Buey near TA-46 \\ Station Analysis \\ 2006 Water Year}

Equipment. Sutron 8210 data logger (5-min. interval) with cellular phone and speech modem housed in a NEMA shelter on left bank. The stage sensor is a milltronics sonic probe mounted on a 2-foot Parshall flume. The station is also equipped with ISCO pump sampler, which is housed in a 4' $\times 4^{\prime}$ metal box on left bank and is triggered by the data logger. All the equipment is powered with a solar panel battery charging system. No provision for discharge measurements above wading stage. All high-flow measurement will be made by slope area or peak flow computation methods. The outside staff is the reference gage.

Field Work. The station was visited ten times for the purpose of making a discharge measurement and/or servicing the instrumentation. Field inspections for the gage are listed under site history files on the Hydstra database. Discharge measurements for the gage are listed under site gauging files on the Hydstra database.

Datum Correction. None.

Gage-Height Record. The data logger referenced to the outside gage in flume gave a complete and satisfactory record for the period except for August 25 to September 30 when sensor support was destroyed by flood.

Rating. The channel is 15 feet wide and straight upstream and downstream for about 100 feet. The streambed through this reach is boulders with sand and gravel. The low flow control is the 2-foot Parshall flume, and at very high flow is channel control.

Rating No. 1 is based on the 2-foot Parshall flume and two peak flow computations.

Ten inspections of no flow were made during the period.

Discharge. Discharge was computed by applying gage height to Rating No. 1 through shift adjustment based on PZF on variable shift diagram for the period of record.

Remarks. Records good. 


\section{E218 Cañada del Buey near TA-46}

Daily Mean Discharge in Cubic Feet per Second

Water Year October 2005 to September 2006

\begin{tabular}{|c|c|c|c|c|c|c|c|c|c|c|c|c|}
\hline DAY & OCT & NOV & DEC & JAN & FEB & MAR & APR & MAY & JUN & JUL & AUG & SEP \\
\hline 1 & 0 & 0 & 0 & 0 & 0 & 0 & 0 & 0 & 0 & 0 & 0 & $0^{*}$ \\
\hline 2 & 0 & 0 & 0 & 0 & 0 & 0 & 0 & 0 & 0 & 0 & 0 & $0^{*}$ \\
\hline 3 & 0 & 0 & 0 & 0 & 0 & 0 & 0 & 0 & 0 & 0 & .14 & $0^{*}$ \\
\hline 4 & .06 & 0 & 0 & 0 & 0 & 0 & 0 & 0 & 0 & 0 & .01 & $0^{*}$ \\
\hline 5 & 0 & 0 & 0 & 0 & 0 & 0 & 0 & 0 & .02 & .14 & 0 & $0^{*}$ \\
\hline 6 & 0 & 0 & 0 & 0 & 0 & 0 & 0 & 0 & 0 & 0 & 0 & $0^{*}$ \\
\hline 7 & 0 & 0 & 0 & 0 & 0 & 0 & 0 & 0 & 0 & 0 & 0 & $0^{*}$ \\
\hline 8 & 0 & 0 & 0 & 0 & 0 & 0 & 0 & 0 & 0 & 0 & 0 & $0^{*}$ \\
\hline 9 & 0 & 0 & .06 & 0 & 0 & 0 & 0 & 0 & 0 & 0 & 0 & $0^{*}$ \\
\hline 10 & 0 & 0 & 0 & 0 & 0 & 0 & 0 & 0 & 0 & 0 & 0 & $0^{*}$ \\
\hline 11 & 0 & 0 & 0 & 0 & 0 & 0 & 0 & 0 & 0 & 0 & 0 & $0^{*}$ \\
\hline 12 & 0 & 0 & 0 & 0 & 0 & 0 & 0 & .01 & 0 & 0 & 0 & $0^{*}$ \\
\hline 13 & 0 & .01 & .12 & 0 & 0 & 0 & 0 & 0 & 0 & 0 & 0 & $0^{*}$ \\
\hline 14 & 0 & 0 & 0 & 0 & 0 & 0 & 0 & 0 & 0 & 0 & .18 & $0^{*}$ \\
\hline 15 & 0 & 0 & 0 & 0 & 0 & .19 & 0 & 0 & .01 & 0 & .17 & $0^{*}$ \\
\hline 16 & 0 & 0 & 0 & 0 & 0 & 0 & 0 & 0 & 0 & 0 & 0 & $0^{*}$ \\
\hline 17 & 0 & 0 & 0 & 0 & 0 & 0 & 0 & .01 & 0 & 0 & 0 & $0^{*}$ \\
\hline 18 & 0 & 0 & 0 & 0 & 0 & 0 & 0 & 0 & 0 & 0 & 0 & $0^{*}$ \\
\hline 19 & 0 & 0 & 0 & 0 & 0 & .24 & 0 & 0 & 0 & 0 & 0 & $0^{*}$ \\
\hline 20 & 0 & 0 & 0 & 0 & 0 & 0 & .03 & 0 & 0 & 0 & .02 & $0^{*}$ \\
\hline 21 & 0 & 0 & 0 & 0 & 0 & 0 & 0 & .01 & 0 & 0 & .16 & $0^{*}$ \\
\hline 22 & 0 & 0 & 0 & 0 & 0 & 0 & 0 & .26 & 0 & 0 & 0 & $0^{*}$ \\
\hline 23 & 0 & .02 & 0 & 0 & 0 & 0 & 0 & .03 & 0 & 0 & 0 & $0^{*}$ \\
\hline 24 & 0 & 0 & .05 & 0 & 0 & 0 & 0 & 0 & 0 & 0 & 0 & $0^{*}$ \\
\hline 25 & 0 & 0 & 0 & 0 & 0 & 0 & 0 & .02 & 0 & 0 & $8.0^{*}$ & $0^{*}$ \\
\hline 26 & 0 & 0 & 0 & 0 & 0 & 0 & 0 & 0 & 0 & 0 & $0^{*}$ & $0^{*}$ \\
\hline 27 & 0 & .21 & 0 & 0 & 0 & 0 & 0 & 0 & 0 & 0 & $0^{*}$ & $0^{*}$ \\
\hline 28 & 0 & 0 & 0 & 0 & 0 & 0 & 0 & 0 & 0 & 0 & $0^{*}$ & $0^{*}$ \\
\hline 29 & 0 & 0 & 0 & 0 & ---- & 0 & 0 & 0 & 0 & 0 & $0^{*}$ & $0^{*}$ \\
\hline 30 & 0 & .05 & 0 & 0 & ---- & 0 & .01 & 0 & 0 & 0 & $0^{*}$ & $0^{*}$ \\
\hline 31 & 0 & & 0 & 0 & ------ & 0 & ----- & 0 & ------ & 0 & $0^{*}$ & ב---- \\
\hline Total & 0.06 & 0.29 & 0.23 & 0 & 0 & 0.43 & 0.04 & 0.34 & 0.03 & 0.14 & 8.68 & 0 \\
\hline Mean & .002 & .010 & .007 & 0 & 0 & .014 & .001 & .011 & .001 & .005 & .28 & 0 \\
\hline Max & .06 & .21 & .12 & 0 & 0 & .24 & .03 & .26 & .02 & .14 & 8.0 & 0 \\
\hline Min & 0 & 0 & 0 & 0 & 0 & 0 & 0 & 0 & 0 & 0 & 0 & 0 \\
\hline Acre-Ft & .12 & .58 & .46 & 0 & 0 & .85 & .08 & .67 & .06 & .28 & 17 & 0 \\
\hline Wtr Year & 2006 & Total & 10.24 & & & & hax & & Min & 0 & Acre-Ft & 20 \\
\hline Cal Year & 2005 & Total & 10.79 & & & & hax & & Min & 0 & Acre-Ft & 21 \\
\hline
\end{tabular}

* Estimated 


\section{E225 Cañada del Buey near MDA G}

Location. Lat. 35 50'1.2", long. 106 $14^{\prime} 22.1^{\prime \prime}$, in Ramon Vigil Grant, Los Alamos County, 0.1 mile south of Santa Fe/Los Alamos county line and 2.5 miles upstream from SR 4 in White Rock, New Mexico.

Drainage Area. $1.48 \mathrm{mi}^{2}$.

Period of Record. October 1993 to September 30, 2006.

Revised Record. Drainage Area (this report).

Gage. Data logger with cellular telemetry and concrete control. Elevation of gage is 6,599 $\mathrm{ft}$ above NGVD from GIS 9.1.

Remarks. Water discharge records good.

Average Discharge. $11 \mathrm{yr}$, zero.

Extremes for Period of Record. Maximum discharge $17 \mathrm{ft}^{3} / \mathrm{s}$, September 8, 1995, gage height $2.71 \mathrm{ft}$. No flow most of time.

Extremes for Current Water Year. Maximum discharge $0.49 \mathrm{ft}^{3} / \mathrm{s}$, August 8 , gage height $1.03 \mathrm{ft}$. No flow most of time.

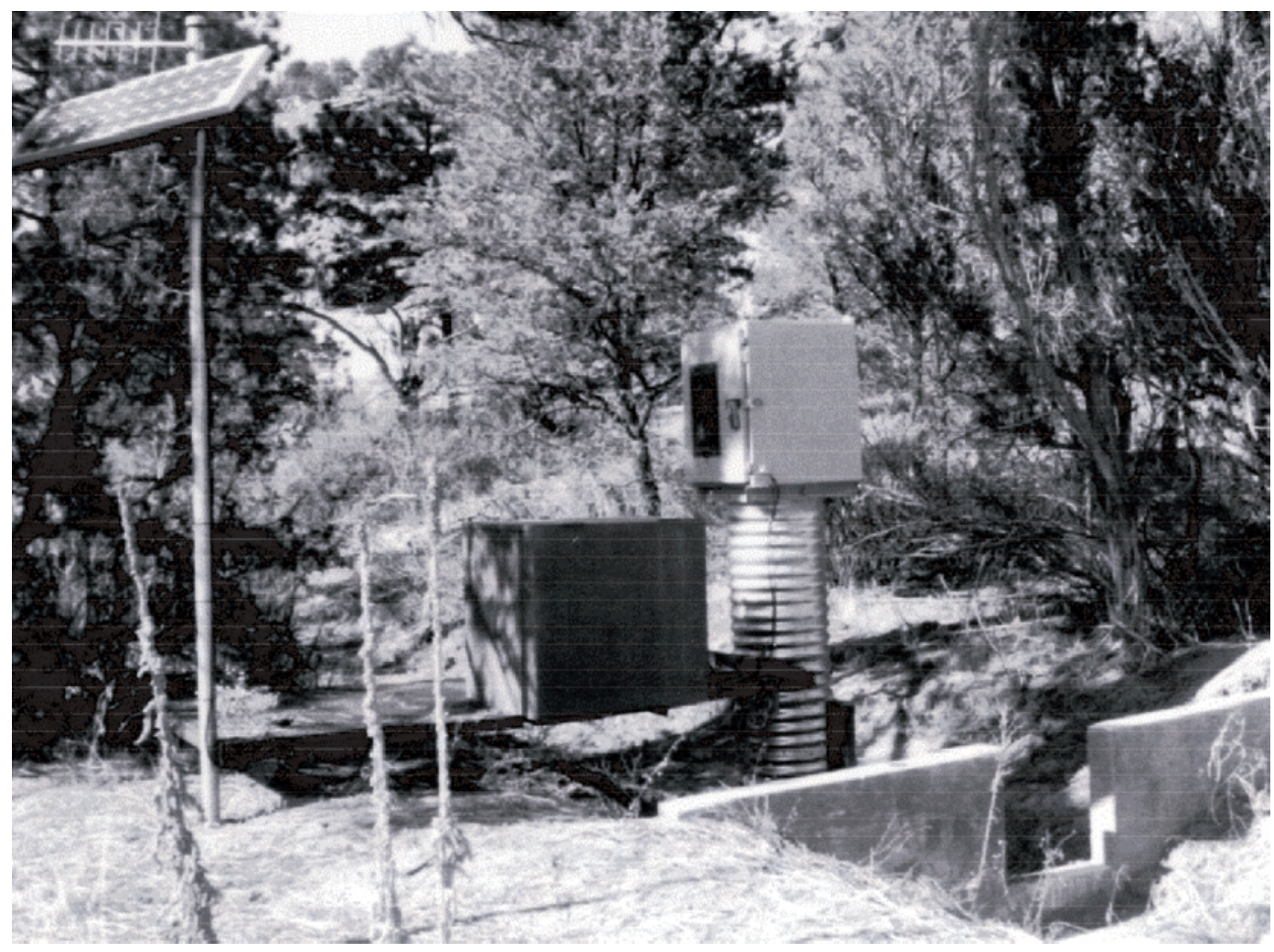




\section{E225 Cañon del Buey near MDA G \\ Station Analysis \\ 2006 Water Year}

Equipment. Sutron 8210 data logger (5-min. interval) housed in a NEMA shelter on 18" CMP well on right bank. Logger is equipped with cellular phone. ISCO automatic sampler is linked to data logger for activation. No provisions for flow measurements above wading stage.

Field Work. The station was visited eleven times for the purpose of making a discharge measurement and/or servicing the instrumentation. Field inspections for the gage are listed under site history files on the Hydstra database. Discharge measurements for the gage are listed under site gauging files on the Hydstra database.

Datum Correction. None.

Gage-Height Record. The data logger record was good and satisfactory for the year.

Rating. Channel is straight for at least 100 feet above and below gage. Bed material is sand with thin covering of grass. The control is a concrete broad-crested weir 10 feet downstream of gage.

Rating No. 1 was developed by broad-crested weir computation.

Eleven inspections of no flow were made during this period.

Discharge. Rating No. 1 was used direct with no shifts. Flow of one day only.

Remarks. Records good. 


\section{E225 Cañada del Buey near MDA G}

Daily Mean Discharge in Cubic Feet per Second

Water Year October 2005 to September 2006

\begin{tabular}{|c|c|c|c|c|c|c|c|c|c|c|c|c|}
\hline DAY & OCT & NOV & DEC & JAN & FEB & MAR & APR & MAY & JUN & JUL & AUG & SEP \\
\hline 1 & 0 & 0 & 0 & 0 & 0 & 0 & 0 & 0 & 0 & 0 & 0 & 0 \\
\hline 2 & 0 & 0 & 0 & 0 & 0 & 0 & 0 & 0 & 0 & 0 & 0 & 0 \\
\hline 3 & 0 & 0 & 0 & 0 & 0 & 0 & 0 & 0 & 0 & 0 & 0 & 0 \\
\hline 4 & 0 & 0 & 0 & 0 & 0 & 0 & 0 & 0 & 0 & 0 & 0 & 0 \\
\hline 5 & 0 & 0 & 0 & 0 & 0 & 0 & 0 & 0 & 0 & 0 & 0 & 0 \\
\hline 6 & 0 & 0 & 0 & 0 & 0 & 0 & 0 & 0 & 0 & 0 & .01 & 0 \\
\hline 7 & 0 & 0 & 0 & 0 & 0 & 0 & 0 & 0 & 0 & 0 & 0 & 0 \\
\hline 8 & 0 & 0 & 0 & 0 & 0 & 0 & 0 & 0 & 0 & 0 & 0 & 0 \\
\hline 9 & 0 & 0 & 0 & 0 & 0 & 0 & 0 & 0 & 0 & 0 & 0 & 0 \\
\hline 10 & 0 & 0 & 0 & 0 & 0 & 0 & 0 & 0 & 0 & 0 & 0 & 0 \\
\hline 11 & 0 & 0 & 0 & 0 & 0 & 0 & 0 & 0 & 0 & 0 & 0 & 0 \\
\hline 12 & 0 & 0 & 0 & 0 & 0 & 0 & 0 & 0 & 0 & 0 & 0 & 0 \\
\hline 13 & 0 & 0 & 0 & 0 & 0 & 0 & 0 & 0 & 0 & 0 & 0 & 0 \\
\hline 14 & 0 & 0 & 0 & 0 & 0 & 0 & 0 & 0 & 0 & 0 & 0 & 0 \\
\hline 15 & 0 & 0 & 0 & 0 & 0 & 0 & 0 & 0 & 0 & 0 & 0 & 0 \\
\hline 16 & 0 & 0 & 0 & 0 & 0 & 0 & 0 & 0 & 0 & 0 & 0 & 0 \\
\hline 17 & 0 & 0 & 0 & 0 & 0 & 0 & 0 & 0 & 0 & 0 & 0 & 0 \\
\hline 18 & 0 & 0 & 0 & 0 & 0 & 0 & 0 & 0 & 0 & 0 & 0 & 0 \\
\hline 19 & 0 & 0 & 0 & 0 & 0 & 0 & 0 & 0 & 0 & 0 & 0 & 0 \\
\hline 20 & 0 & 0 & 0 & 0 & 0 & 0 & 0 & 0 & 0 & 0 & 0 & 0 \\
\hline 21 & 0 & 0 & 0 & 0 & 0 & 0 & 0 & 0 & 0 & 0 & 0 & 0 \\
\hline 22 & 0 & 0 & 0 & 0 & 0 & 0 & 0 & 0 & 0 & 0 & 0 & 0 \\
\hline 23 & 0 & 0 & 0 & 0 & 0 & 0 & 0 & 0 & 0 & 0 & 0 & 0 \\
\hline 24 & 0 & 0 & 0 & 0 & 0 & 0 & 0 & 0 & 0 & 0 & 0 & 0 \\
\hline 25 & 0 & 0 & 0 & 0 & 0 & 0 & 0 & 0 & 0 & 0 & 0 & 0 \\
\hline 26 & 0 & 0 & 0 & 0 & 0 & 0 & 0 & 0 & 0 & 0 & 0 & 0 \\
\hline 27 & 0 & 0 & 0 & 0 & 0 & 0 & 0 & 0 & 0 & 0 & 0 & 0 \\
\hline 28 & 0 & 0 & 0 & 0 & 0 & 0 & 0 & 0 & 0 & 0 & 0 & 0 \\
\hline 29 & 0 & 0 & 0 & 0 & ------ & 0 & 0 & 0 & 0 & 0 & 0 & 0 \\
\hline 30 & 0 & 0 & 0 & 0 & ------ & 0 & 0 & 0 & 0 & 0 & 0 & 0 \\
\hline 31 & 0 & ------ & 0 & 0 & ------ & 0 & ------- & 0 & ------ & 0 & 0 & ----- \\
\hline Total & 0 & 0 & 0 & 0 & 0 & 0 & 0 & 0 & 0 & 0 & 0.01 & 0 \\
\hline Mean & 0 & 0 & 0 & 0 & 0 & 0 & 0 & 0 & 0 & 0 & 0 & 0 \\
\hline Max & 0 & 0 & 0 & 0 & 0 & 0 & 0 & 0 & 0 & 0 & .01 & 0 \\
\hline Min & 0 & 0 & 0 & 0 & 0 & 0 & 0 & 0 & 0 & 0 & 0 & 0 \\
\hline Acre-Ft & 0 & 0 & 0 & 0 & 0 & 0 & 0 & 0 & 0 & 0 & .02 & 0 \\
\hline Wtr Year & 2006 & Total & 0.01 & Mean & ( & & Max & 11 & Min & 0 & Acre-Ft & .02 \\
\hline Cal Year & 2005 & Total & 0 & Mean & c & & Max & & Min & 0 & Acre-Ft & 0 \\
\hline
\end{tabular}




\section{E230 Cañada del Buey above SR 4}

Location. Lat. 35'49'38", long. $106^{\circ} 12^{\prime} 43^{\prime \prime}$, in Ramon Vigil Grant, Los Alamos County, on left bank $250 \mathrm{ft}$ upstream from SR 4 in White Rock, New Mexico.

Drainage Area. $2.15 \mathrm{mi}^{2}$.

Period of Record. October 1991 to September 30, 2006.

Revised Record. Drainage Area (this report).

Gage. Data logger with cellular telemetry and concrete control. Elevation of gage is 6,395 $\mathrm{ft}$ above NGVD from GIS 9.1.

Remarks. Water discharge records good.

Average Discharge. $12 \mathrm{yr}, 0.010 \mathrm{ft}^{3} / \mathrm{s}, 7.2$ acre- $\mathrm{ft} / \mathrm{yr}$.

Extremes for Period of Record. Maximum discharge $210 \mathrm{ft}^{3} / \mathrm{s}$, June 17, 1999, gage height $3.30 \mathrm{ft}$. No flow most of time.

Extremes for Current Water Year. Maximum discharge $54 \mathrm{ft}^{3} / \mathrm{s}$ at $0040 \mathrm{~h}$, August 6, gage height $1.65 \mathrm{ft}$. No flow most of time.

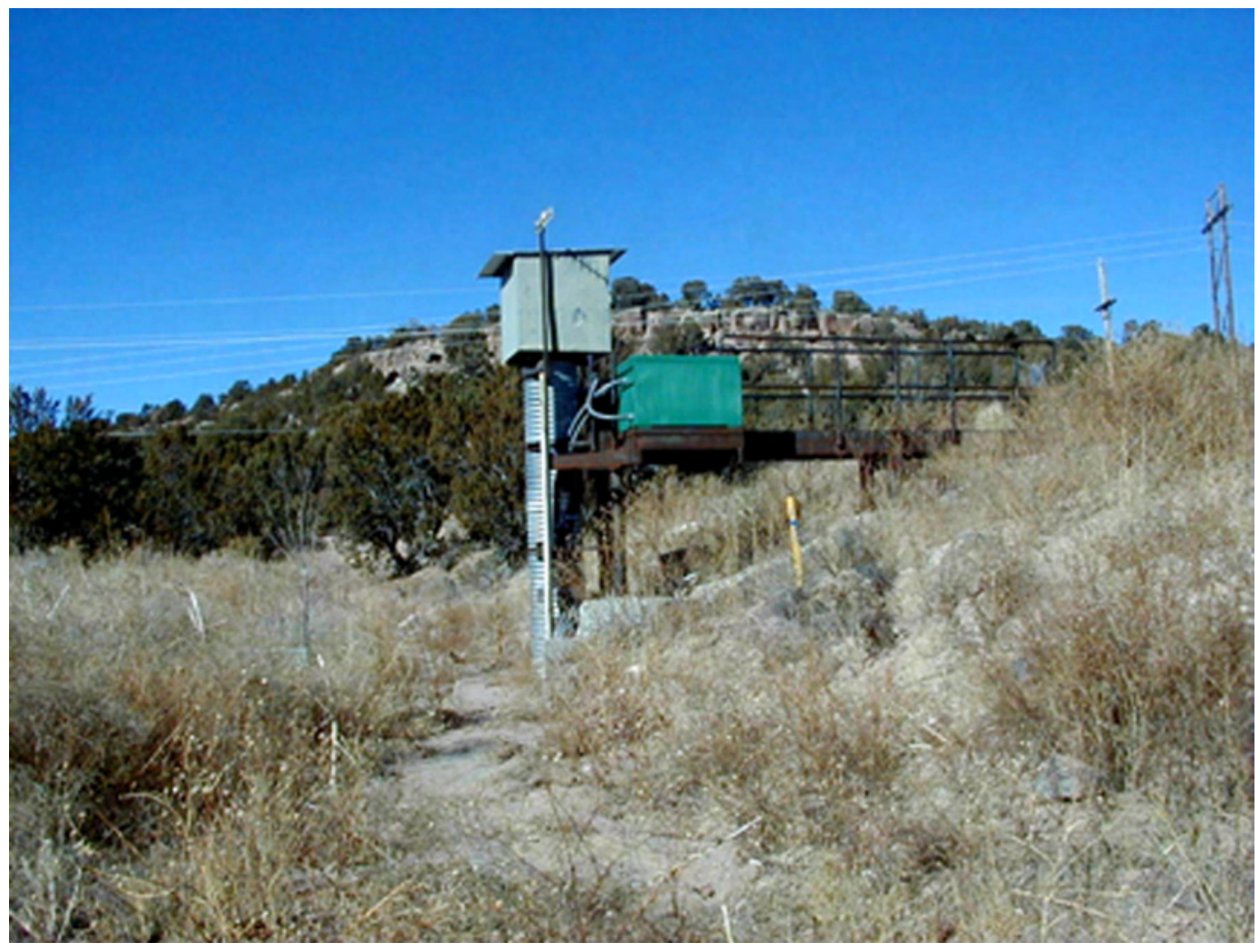




\section{E230 Cañada del Buey above SR 4 \\ Station Analysis \\ 2006 Water Year}

Equipment. Sutron 8210 data logger (5-min. interval) with cellular phone in 40" shelter on top of 24" CMP well on right bank. Reference gage is electric tape with outside staff also available. Auxiliary shelter houses ISCO brand automatic sampler, which is triggered by stage through the data logger. A second auxiliary shelter will accommodate 2 additional ISCO samplers. Temporary site for dye study.

Field Work. The station was visited sixteen times for the purpose of making a discharge measurement and/or servicing the instrumentation. Field inspections for the gage are listed under site history files on the Hydstra database. Discharge measurements for the gage are listed under site gauging files on the Hydstra database.

Datum Correction. None.

Gage-Height Record. The data logger reference to the outside staff gave a complete and satisfactory record for the period, except for silting on recession of most peaks.

Rating. Channel has fairly sharp right bend 50 feet above gage where two channels confluence. It is straight for 100 feet below gage where it enters a rectangular double-box culvert under NM State Highway 4. Control is tapered (low-end on left) broad-crested weir.

Rating No. 1 is based on discharge measurements No. 1-8 and fifteen inspections of no flow were made during the year.

Discharge. Rating No. 1 was used for the entire water year and is considered good.

Remarks. Records good. 


\section{E230 Cañada del Buey above SR 4}

Daily Mean Discharge in Cubic Feet per Second

Water Year October 2005 to September 2006

\begin{tabular}{|c|c|c|c|c|c|c|c|c|c|c|c|c|}
\hline DAY & OCT & NOV & DEC & JAN & FEB & MAR & APR & MAY & JUN & $\begin{array}{l}\text { JUL } \\
\end{array}$ & AUG & SEP \\
\hline 1 & 0 & 0 & 0 & 0 & 0 & 0 & 0 & 0 & 0 & 0 & .20 & 0 \\
\hline 2 & 0 & 0 & 0 & 0 & 0 & 0 & 0 & 0 & 0 & 0 & 0 & 0 \\
\hline 3 & 0 & 0 & 0 & 0 & 0 & 0 & 0 & 0 & 0 & .01 & 0 & 0 \\
\hline 4 & 0 & 0 & 0 & 0 & 0 & 0 & 0 & 0 & 0 & 0 & 0 & 0 \\
\hline 5 & 0 & 0 & 0 & 0 & 0 & 0 & 0 & 0 & 0 & .52 & .05 & 0 \\
\hline 6 & .01 & 0 & 0 & 0 & 0 & 0 & 0 & 0 & 0 & 0 & 2.0 & 0 \\
\hline 7 & 0 & 0 & 0 & 0 & 0 & 0 & 0 & 0 & 0 & 0 & 0 & 0 \\
\hline 8 & 0 & 0 & 0 & 0 & 0 & 0 & 0 & 0 & 0 & 0 & 0 & 0 \\
\hline 9 & .17 & 0 & 0 & 0 & 0 & 0 & 0 & 0 & 0 & 0 & 0 & 0 \\
\hline 10 & 0 & 0 & 0 & 0 & 0 & 0 & 0 & 0 & 0 & 0 & 0 & 0 \\
\hline 11 & 0 & 0 & 0 & 0 & 0 & 0 & 0 & 0 & 0 & 0 & 0 & 0 \\
\hline 12 & 0 & 0 & 0 & 0 & 0 & 0 & 0 & 0 & 0 & 0 & 0 & 0 \\
\hline 13 & 0 & 0 & 0 & 0 & 0 & 0 & 0 & 0 & 0 & 0 & 0 & 0 \\
\hline 14 & 0 & 0 & 0 & 0 & 0 & 0 & 0 & 0 & 0 & 0 & 0 & 0 \\
\hline 15 & 0 & 0 & 0 & 0 & 0 & 0 & 0 & 0 & 0 & 0 & 0 & 0 \\
\hline 16 & 0 & 0 & 0 & 0 & 0 & 0 & 0 & 0 & 0 & 0 & 0 & 0 \\
\hline 17 & 0 & 0 & 0 & 0 & 0 & 0 & 0 & 0 & 0 & 0 & 0 & 0 \\
\hline 18 & 0 & 0 & 0 & 0 & 0 & 0 & 0 & 0 & 0 & 0 & 0 & 0 \\
\hline 19 & .04 & 0 & 0 & 0 & 0 & 0 & 0 & 0 & 0 & 0 & .11 & 0 \\
\hline 20 & 0 & 0 & 0 & 0 & 0 & 0 & 0 & 0 & 0 & 0 & .10 & .01 \\
\hline 21 & 0 & 0 & 0 & 0 & 0 & 0 & 0 & 0 & 0 & 0 & .03 & 0 \\
\hline 22 & 0 & 0 & 0 & 0 & 0 & 0 & 0 & 0 & 0 & 0 & 0 & 0 \\
\hline 23 & 0 & 0 & 0 & 0 & 0 & 0 & 0 & 0 & 0 & 0 & 0 & 0 \\
\hline 24 & 0 & 0 & 0 & 0 & 0 & 0 & 0 & 0 & 0 & 0 & 0 & 0 \\
\hline 25 & 0 & 0 & 0 & 0 & 0 & 0 & 0 & 0 & 0 & 0 & 0 & 0 \\
\hline 26 & 0 & 0 & 0 & 0 & 0 & 0 & 0 & 0 & 0 & 0 & 0 & 0 \\
\hline 27 & 0 & 0 & 0 & 0 & 0 & 0 & 0 & 0 & 0 & 0 & 0 & 0 \\
\hline 28 & 0 & 0 & 0 & 0 & 0 & 0 & 0 & 0 & 0 & 0 & 0 & 0 \\
\hline 29 & 0 & 0 & 0 & 0 & ----- & 0 & 0 & 0 & 0 & 0 & 0 & 0 \\
\hline 30 & 0 & 0 & 0 & 0 & ------ & 0 & 0 & 0 & 0 & 0 & 0 & 0 \\
\hline 31 & 0 & ------ & 0 & 0 & ----- & 0 & ---- & 0 & ----- & 0 & 0 & ----- \\
\hline Total & 0.22 & 0 & 0 & 0 & 0 & 0 & 0 & 0 & 0 & 0.53 & 2.49 & 0.01 \\
\hline Mean & .007 & 0 & 0 & 0 & 0 & 0 & 0 & 0 & 0 & .017 & .080 & 0 \\
\hline $\operatorname{Max}$ & .17 & 0 & 0 & 0 & 0 & 0 & 0 & 0 & 0 & .52 & 2.0 & .01 \\
\hline Min & 0 & 0 & 0 & 0 & 0 & 0 & 0 & 0 & 0 & 0 & 0 & 0 \\
\hline Acre-Ft & .44 & 0 & 0 & 0 & 0 & 0 & 0 & 0 & 0 & 1.1 & 4.9 & .02 \\
\hline Wtr Year & 2006 & Total & 3.25 & Mean & .009 & & Max & & Min & 0 & Acre-Ft & 6.4 \\
\hline Cal Year & 2005 & Total & 1.46 & Mean & .004 & & Max & & Min & 0 & Acre-Ft & 2.9 \\
\hline
\end{tabular}




\section{E240 Pajarito below SR 501}

Location. Lat. 3552'02", long. 106²1'05", SE 1/4, NW 1/4, sec. 19, T. 19 N, R. 6 E, Los Alamos County, in Santa Fe National Forest, $100 \mathrm{ft}$ downstream from NM SR 501.

Drainage Area. $1.90 \mathrm{mi}^{2}$.

Period of Record. October 1993 to June 28, 2000 (destroyed by flood); April 2001 to September 30, 2006.

Revised Records. WDR 1997: Gage height “Extremes for Period of Record.” Drainage Area (this report).

Gage. Data logger with cellular telemetry. Elevation of gage is $7,719 \mathrm{ft}$ above NGVD from GIS 9.1. Formerly published as "Pajarito Canyon above Highway 501 near Los Alamos, NM" at different datum.

Remarks. Records poor.

Average Discharge. $12 \mathrm{yr}, 0.11 \mathrm{ft}^{3} / \mathrm{s}, 80$ acre- $\mathrm{ft} / \mathrm{yr}$.

Extremes for Period of Record. Maximum discharge 1,020 $\mathrm{ft}^{3} / \mathrm{s}$, June 28, 2000, from peak flow computation, gage height not determined. No flow at times.

Extremes for Current Water Year. Maximum discharge $16 \mathrm{ft}^{3} / \mathrm{s}$ on August 8, gage height $1.22 \mathrm{ft}$ (from flood mark). No flow most of time.

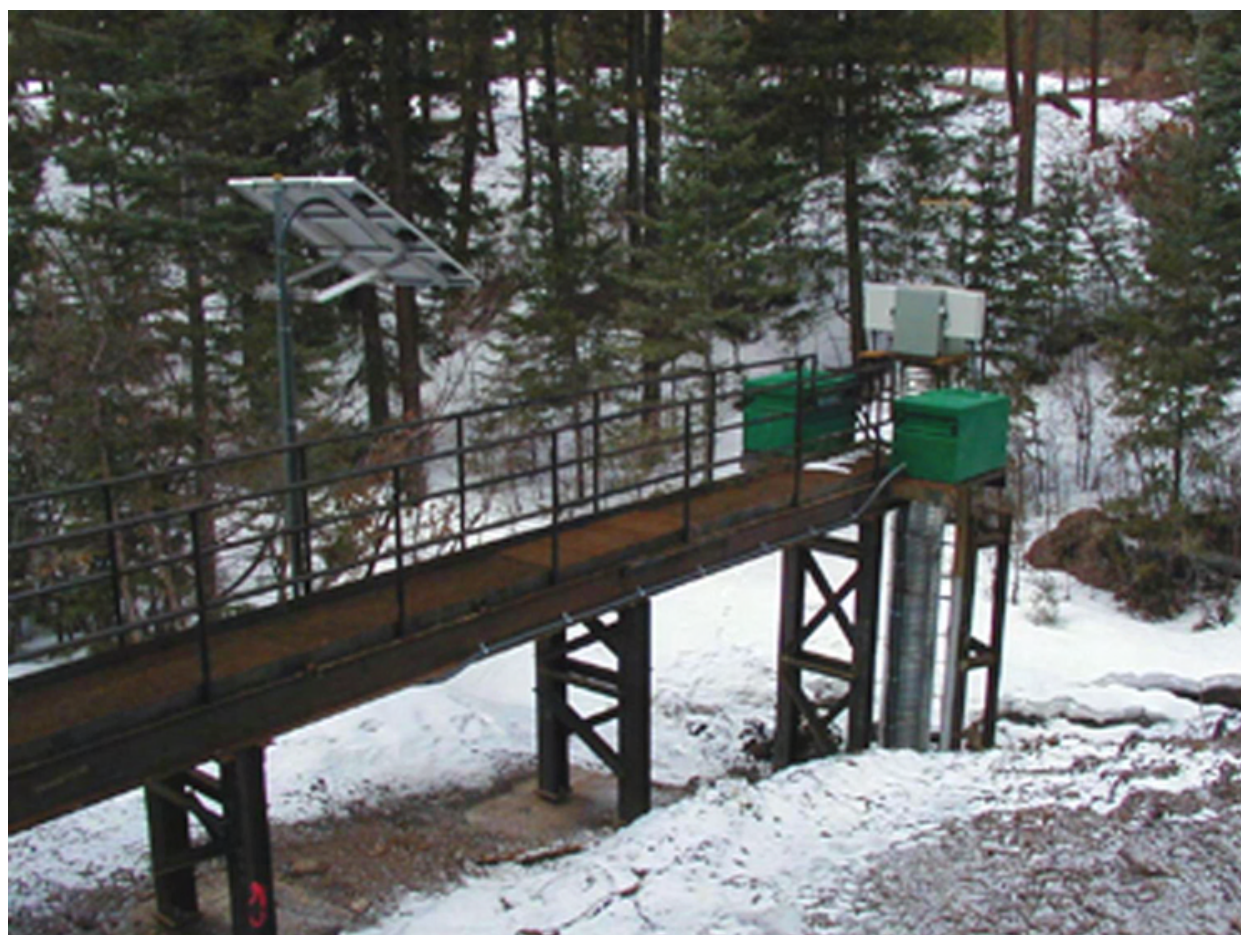




\section{E240 Pajarito below SR 501 \\ Station Analysis \\ 2006 Water Year}

Equipment. Sutron 8210 data logger (5-min. interval) with cellular telemetry and speech modem. The stage sensor is quadrature encoder that is float driven (5-min. interval). Instruments are housed in NEMA shelter on top of 24" CMP stilling well on left bank. Two ISCO brand automatic samplers are housed in separate shelters and are both stage activated through the data logger. The outside staff is the reference gage. Tipping bucket raingage operated at this station.

Field Work. The station was visited twenty two times for the purpose of making a discharge measurement and/or servicing the instrumentation. Field inspections for the gage are listed under site history files on the Hydstra database. Discharge measurements for the gage are listed under site gauging files on the Hydstra database.

Datum Correction. None from levels run in December 11, 2004.

Gage-Height Record. The data logger referenced to the outside staff gave a complete and satisfactory record except April 9-19, May 15 to June 10, and June 30 to July 21, when data logger malfunctioned.

Rating. Gage is about 100 yards below outlet of 2 round culverts through Highway 501 roadbed. Channel bed is sand and gravel and subject to movement. Grass and brush are fairly thick in over banks areas. Banks are not high (about 1-2 ft most places). Two gabions were installed in the fall of 2001, which act as low water controls. One is 2 feet below gage across entire width of channel with a 6-inch $\mathrm{V}$ notch for low water. Other gabion is 50 feet above gage.

Rating No. 2 was developed at this essentially new site. One discharge measurement (No. 22) and twenty two inspections of no flow were made this year. All less than $1 \mathrm{cfs}$ and plot roughly $0.60 \mathrm{ft}$ left of Rating No. 2. Rating No. 2 is fast becoming noneffective, but discharge measurements are not available to create new rating. Large shifts were applied throughout the range of Rating No. 2. Low end point varies, but middle and upper stage set at $0.5 \mathrm{ft}$.

Discharge. Discharge was computed by applying Rating No. 2 using variable shift diagrams. Shifts are large and negative. Annual maximum was computed using high water mark (HWM). Missing periods were estimated using E241.

Remarks. Records poor. 


\section{E240 Pajarito below SR 501}

Daily Mean Discharge in Cubic Feet per Second

Water Year October 2005 to September 2006

\begin{tabular}{|c|c|c|c|c|c|c|c|c|c|c|c|c|}
\hline DAY & OCT & NOV & DEC & JAN & FEB & MAR & APR & MAY & JUN & JUL & AUG & SEP \\
\hline 1 & 0 & 0 & 0 & 0 & 0 & 0 & 0 & 0 & $0^{*}$ & $0^{*}$ & 0 & 0 \\
\hline 2 & 0 & 0 & 0 & 0 & 0 & 0 & 0 & 0 & $0^{*}$ & $0^{*}$ & 0 & 0 \\
\hline 3 & 0 & 0 & 0 & 0 & 0 & 0 & 0 & 0 & $0^{*}$ & $0^{*}$ & 0 & 0 \\
\hline 4 & 0 & 0 & 0 & 0 & 0 & 0 & 0 & 0 & $0^{*}$ & $0^{*}$ & .11 & 0 \\
\hline 5 & 0 & 0 & 0 & 0 & 0 & 0 & 0 & 0 & $0^{*}$ & $0^{*}$ & .16 & 0 \\
\hline 6 & 0 & 0 & 0 & 0 & 0 & 0 & 0 & 0 & $0^{*}$ & $0^{*}$ & .01 & 0 \\
\hline 7 & 0 & 0 & 0 & 0 & 0 & 0 & 0 & 0 & $0^{*}$ & $0^{*}$ & .01 & 0 \\
\hline 8 & 0 & 0 & 0 & 0 & 0 & 0 & 0 & 0 & $0^{*}$ & $0^{*}$ & .38 & 0 \\
\hline 9 & 0 & 0 & 0 & 0 & 0 & 0 & $0^{*}$ & 0 & $0^{*}$ & $0^{*}$ & 0 & 0 \\
\hline 10 & 0 & 0 & 0 & 0 & 0 & 0 & $0^{*}$ & 0 & 0 & $0^{*}$ & 0 & 0 \\
\hline 11 & 0 & 0 & 0 & 0 & 0 & 0 & $0^{*}$ & 0 & 0 & $0^{*}$ & 0 & .10 \\
\hline 12 & 0 & 0 & 0 & 0 & 0 & 0 & $0^{*}$ & 0 & 0 & $0^{*}$ & 0 & 0 \\
\hline 13 & 0 & 0 & 0 & 0 & 0 & 0 & $0^{*}$ & 0 & 0 & $0^{*}$ & .01 & 0 \\
\hline 14 & 0 & 0 & 0 & 0 & 0 & 0 & $0^{*}$ & 0 & 0 & $0^{*}$ & 0 & 0 \\
\hline 15 & 0 & 0 & 0 & 0 & 0 & 0 & $0^{*}$ & $0^{*}$ & 0 & $0^{*}$ & .01 & 0 \\
\hline 16 & 0 & 0 & 0 & 0 & 0 & 0 & $0^{*}$ & $0^{*}$ & 0 & $0^{*}$ & 0 & 0 \\
\hline 17 & 0 & 0 & 0 & 0 & 0 & 0 & $0^{*}$ & $0^{*}$ & 0 & $0^{*}$ & 0 & 0 \\
\hline 18 & 0 & 0 & 0 & 0 & 0 & 0 & $0^{*}$ & $0^{*}$ & 0 & $0^{*}$ & 0 & 0 \\
\hline 19 & 0 & 0 & 0 & 0 & 0 & 0 & $0^{*}$ & $0^{*}$ & 0 & $0^{*}$ & 0 & 0 \\
\hline 20 & 0 & 0 & 0 & 0 & 0 & 0 & 0 & $0^{*}$ & 0 & $0^{*}$ & .10 & 0 \\
\hline 21 & 0 & 0 & 0 & 0 & 0 & 0 & 0 & $0^{*}$ & 0 & $0^{*}$ & 0 & 0 \\
\hline 22 & 0 & 0 & 0 & 0 & 0 & 0 & 0 & $0^{*}$ & 0 & .01 & 0 & 0 \\
\hline 23 & 0 & 0 & 0 & 0 & 0 & 0 & 0 & $0^{*}$ & 0 & .02 & 0 & 0 \\
\hline 24 & 0 & 0 & 0 & 0 & 0 & 0 & 0 & $0^{*}$ & 0 & .03 & 0 & 0 \\
\hline 25 & 0 & 0 & 0 & 0 & 0 & 0 & 0 & $0^{*}$ & 0 & .03 & .15 & 0 \\
\hline 26 & 0 & 0 & 0 & 0 & 0 & 0 & 0 & $0^{*}$ & 0 & 0 & 0 & 0 \\
\hline 27 & 0 & 0 & 0 & 0 & 0 & 0 & 0 & $0^{*}$ & 0 & 0 & 0 & 0 \\
\hline 28 & 0 & 0 & 0 & 0 & 0 & 0 & 0 & $0^{*}$ & 0 & 0 & 0 & 0 \\
\hline 29 & 0 & 0 & 0 & 0 & ------- & 0 & 0 & $0^{*}$ & 0 & 0 & 0 & 0 \\
\hline 30 & 0 & 0 & 0 & 0 & ------ & 0 & 0 & $0^{*}$ & $0^{*}$ & 0 & 0 & 0 \\
\hline 31 & 0 & ----- & 0 & 0 & ----- & 0 & ---- & $0^{*}$ & ----- & 0 & 0 & ----- \\
\hline Total & 0 & 0 & 0 & 0 & 0 & 0 & 0 & 0 & 0 & 0.09 & 0.94 & 0.10 \\
\hline Mean & 0 & 0 & 0 & 0 & 0 & 0 & 0 & 0 & 0 & .003 & .030 & .003 \\
\hline Max & 0 & 0 & 0 & 0 & 0 & 0 & 0 & 0 & 0 & .03 & .38 & .10 \\
\hline Min & 0 & 0 & 0 & 0 & 0 & 0 & 0 & 0 & 0 & 0 & 0 & 0 \\
\hline Acre-Ft & 0 & 0 & 0 & 0 & 0 & 0 & 0 & 0 & 0 & .18 & 1.9 & .20 \\
\hline Wtr Year & 2006 & Total & 1.13 & Mean & .003 & & Max & .38 & Min & 0 & Acre-Ft & 2.2 \\
\hline Cal Year & 2005 & Total & 65.68 & Mean & .18 & & $\operatorname{Max}$ & 3.1 & Min & 0 & Acre-Ft & 130 \\
\hline
\end{tabular}

* Estimated 


\section{E241 Pajarito above Starmers}

Location. Lat. 3551'33.6", long. 106²0'12.6", SW 1/4 sec. 20, T. 19 N, R. 6 E, Los Alamos County, $100 \mathrm{ft}$ upstream from mouth of Starmer's Gulch (E242), 0.5 mile south of LANL TA-22, Building 91.

Drainage Area. $3.97 \mathrm{mi}^{2}$.

Period of Record. March 1999 to June 28, 2000 (destroyed by flood); July 2001 to September 30, 2006.

Revised Record. Drainage Area (this report).

Gage. Data logger with cellular telemetry and $90^{\circ}$ sharp-crested weir. Elevation of gage is 7,382 ft above NGVD from GIS 9.1.

Remarks. Records good, except for estimated daily discharges, which are poor.

Average Discharge. $6 \mathrm{yr}, 0.07 \mathrm{ft}^{3} / \mathrm{s}, 51$ acre $\mathrm{ft} / \mathrm{yr}$.

Extremes for Period of Record. Maximum discharge $300 \mathrm{ft}^{3} / \mathrm{s}$, June 28, 2000, from peak flow computation, gage height $5.00 \mathrm{ft}$. No flow at times.

Extremes for Current Water Year. Maximum discharge $20 \mathrm{ft}^{3} / \mathrm{s}$ at $1230 \mathrm{~h}$, August 8, gage height $2.84 \mathrm{ft}$. No flow most of time.

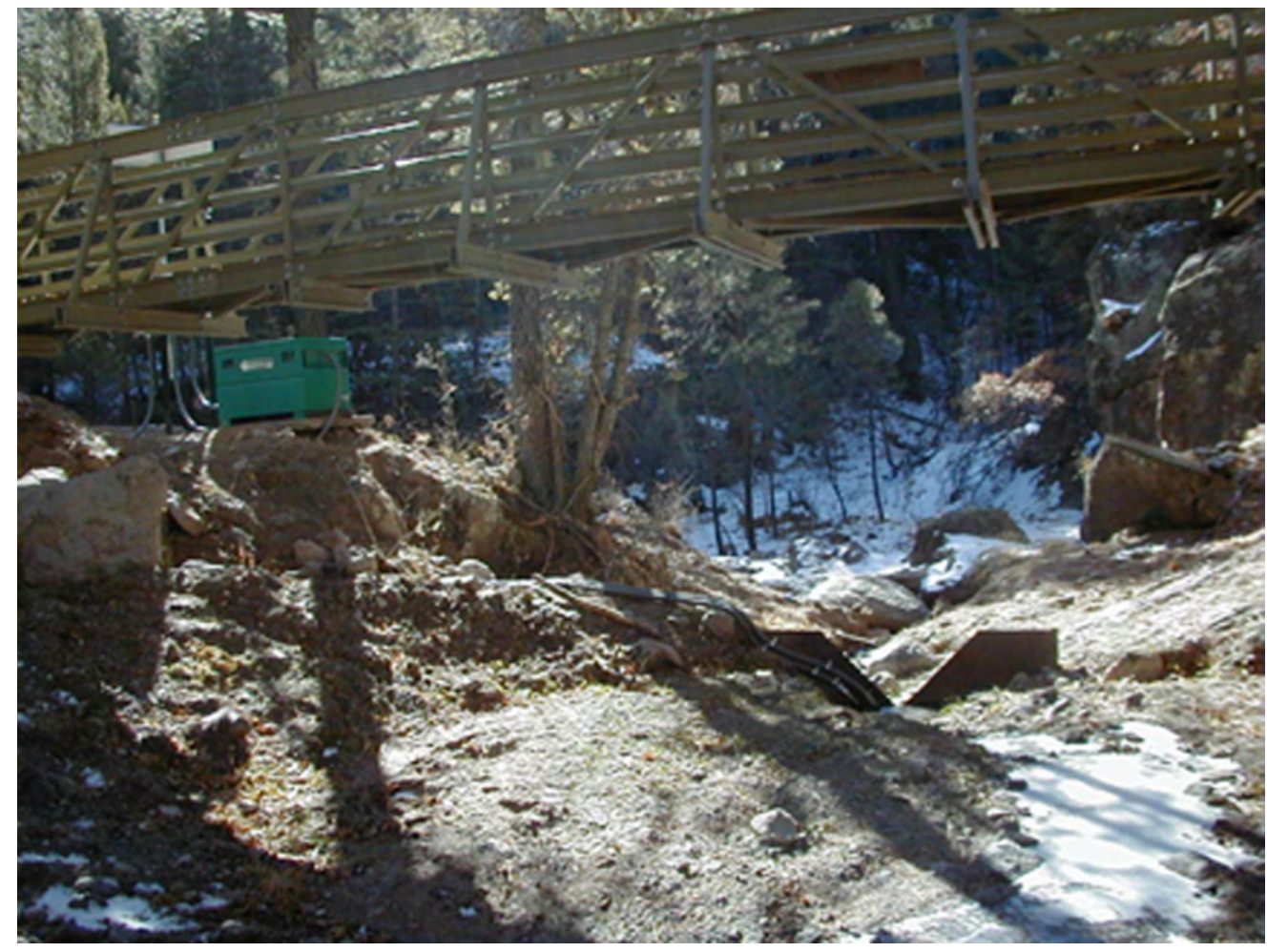




\section{E241 Pajarito above Starmers \\ Station Analysis \\ 2006 Water Year}

Equipment. Sutron 8210 data logger with cellular telephone telemetry and logger-activated ISCO automatic sampler. Gage was rebuilt after destruction by 06-28-2000 flood. Recording instruments are the same. Stage sensor now is a Sutron model bubbler gage. Tape A wire weigh gage is installed on downstream side of bridge. Footbridge was installed as part of reconstruction and may be used for high-flow measurements and sampling. It also provides access to gage E242 during high-flow periods.

Field Work. The station was visited twenty six times for the purpose of making a discharge measurement and/or servicing the instrumentation. Field inspections for the gage are listed under site history files on the Hydstra database. Discharge measurements for the gage are listed under site gauging files on the Hydstra database.

Datum Correction. Last levels run August 8, 2001, found the wire weight gage and PZF within limits. No changes necessary.

Gage-Height Record. The data logger referenced to the outside and wire weight gage gave a complete and satisfactory report for the period except January 7-9 when power failed.

Rating. The channel is straight for 100 feet above and below weir. Stream banks have significant vegetation, and streambed is sand and gravel armored.

Rating No. 2 is standard 90-degree sharp-crested weir-formula. Point of zero flow is 0.70 feet from levels. Weir should be very effective with virtually no approach velocity to interfere.

Ten discharge measurements (Nos. 32-41) were made during the period. Shifts defined by measurements were used for " $V$ " diagrams. These were applied to lower end with no shifting above $2 \mathrm{ft} / \mathrm{s}$. Shifts were computed and record worked to inside gage readings. Although wire weight is reference gage, natural fall occurs between the wire weight and the orifice from filling after flow events. Effectively the wire weight becomes a general check gage in this station.

Discharge. Computed from Rating No. 2 with "V" diagrams for the entire water year. Records for estimated days were estimated using field notes.

Remarks. Records good except for estimated daily discharges, which are fair. 
E241 Pajarito above Starmers

Daily Mean Discharge in Cubic Feet per Second

Water Year October 2005 to September 2006

\begin{tabular}{|c|c|c|c|c|c|c|c|c|c|c|c|c|}
\hline DAY & OCT & NOV & DEC & JAN & FEB & MAR & APR & MAY & JUN & JUL & AUG & SEP \\
\hline 1 & .06 & .02 & .01 & .01 & 0 & 0 & 0 & 0 & 0 & 0 & 0 & .12 \\
\hline 2 & .06 & .02 & .01 & .01 & 0 & 0 & 0 & 0 & 0 & 0 & 0 & .05 \\
\hline 3 & .05 & .01 & .02 & .01 & 0 & 0 & 0 & 0 & 0 & .04 & 0 & .04 \\
\hline 4 & .05 & .01 & .02 & .01 & 0 & 0 & 0 & 0 & 0 & .01 & 0 & .04 \\
\hline 5 & .04 & .01 & .02 & .01 & 0 & 0 & 0 & 0 & 0 & .07 & .04 & .04 \\
\hline 6 & .03 & .01 & .02 & .01 & 0 & 0 & 0 & 0 & 0 & .02 & .02 & .03 \\
\hline 7 & .03 & .01 & .03 & $.01^{*}$ & 0 & 0 & 0 & 0 & 0 & .02 & .04 & .01 \\
\hline 8 & .02 & .01 & .03 & $.01^{*}$ & 0 & 0 & 0 & 0 & 0 & .02 & .61 & .01 \\
\hline 9 & .02 & .01 & .03 & $.01^{*}$ & 0 & .01 & 0 & 0 & 0 & .02 & .05 & .01 \\
\hline 10 & .02 & .01 & .03 & 0 & 0 & .01 & 0 & 0 & 0 & .02 & .03 & .01 \\
\hline 11 & .03 & .01 & .03 & 0 & 0 & .01 & 0 & 0 & 0 & .01 & .02 & .20 \\
\hline 12 & .03 & .01 & .03 & 0 & 0 & .01 & 0 & 0 & 0 & .01 & .02 & .04 \\
\hline 13 & .03 & .01 & .01 & 0 & 0 & .01 & 0 & .01 & 0 & .01 & .02 & .04 \\
\hline 14 & .03 & .01 & .01 & 0 & 0 & 0 & 0 & .01 & 0 & .01 & .02 & .03 \\
\hline 15 & .03 & .01 & .02 & 0 & 0 & 0 & 0 & .01 & 0 & .01 & .02 & .03 \\
\hline 16 & .03 & .01 & .03 & 0 & 0 & 0 & 0 & .01 & 0 & 0 & .02 & .03 \\
\hline 17 & .03 & .02 & .02 & .01 & 0 & 0 & 0 & .01 & 0 & 0 & .01 & .02 \\
\hline 18 & .03 & .02 & .02 & .01 & 0 & .01 & 0 & .01 & 0 & 0 & .01 & .02 \\
\hline 19 & .04 & .02 & .02 & .01 & .01 & .01 & 0 & 0 & 0 & 0 & .02 & .02 \\
\hline 20 & .03 & .02 & .01 & .01 & .01 & .01 & 0 & 0 & 0 & 0 & .08 & .02 \\
\hline 21 & .03 & .01 & .01 & .01 & 0 & .01 & 0 & 0 & 0 & 0 & .02 & .02 \\
\hline 22 & .03 & 0 & .01 & .01 & .01 & .01 & 0 & 0 & 0 & 0 & .02 & .02 \\
\hline 23 & .03 & 0 & 0 & .01 & 0 & .01 & 0 & 0 & 0 & 0 & .02 & .02 \\
\hline 24 & .03 & 0 & 0 & .01 & 0 & .01 & 0 & 0 & 0 & 0 & .02 & .02 \\
\hline 25 & .03 & 0 & 0 & .01 & 0 & .01 & 0 & 0 & 0 & 0 & .40 & .02 \\
\hline 26 & .02 & 0 & 0 & 0 & 0 & 0 & 0 & 0 & 0 & 0 & .06 & .02 \\
\hline 27 & .02 & 0 & 0 & 0 & 0 & 0 & 0 & 0 & 0 & 0 & .05 & .02 \\
\hline 28 & .04 & 0 & 0 & 0 & 0 & 0 & 0 & 0 & 0 & 0 & .05 & .02 \\
\hline 29 & .03 & 0 & .01 & 0 & ----- & 0 & 0 & 0 & 0 & 0 & .05 & .02 \\
\hline 30 & .02 & .01 & .01 & .01 & ---- & 0 & 0 & 0 & 0 & 0 & .05 & .02 \\
\hline 31 & .02 & ----- & .01 & .01 & ------ & 0 & ----- & 0 & ----- & 0 & .04 & ----- \\
\hline Total & 0.99 & 0.28 & 0.47 & 0.20 & 0.03 & 0.13 & 0 & 0.06 & 0 & 0.27 & 1.81 & 1.01 \\
\hline Mean & .032 & .009 & .015 & .007 & .001 & .004 & 0 & .002 & 0 & .009 & .058 & .034 \\
\hline Max & .06 & .02 & .03 & .01 & .01 & .01 & 0 & .01 & 0 & .07 & .61 & .20 \\
\hline Min & .02 & 0 & 0 & 0 & 0 & 0 & 0 & 0 & 0 & 0 & 0 & .01 \\
\hline Acre-Ft & 2.0 & .56 & .93 & .40 & .06 & .26 & 0 & .12 & 0 & .54 & 3.6 & 2.0 \\
\hline Wtr Year & 2006 & Total & 5.25 & $\mathrm{Me}$ & .01 & & Max & $\$ 1$ & Min & 0 & Acre-Ft & 10 \\
\hline Cal Year & 2005 & Total & 41.26 & $\mathrm{Me}$ & .11 & & Max & & Min & 0 & Acre-Ft & 82 \\
\hline
\end{tabular}




\section{E242 Starmers above Pajarito}

Location. Lat. 3551'33.0", long. 106²0'13.0", SW 1/4 sec. 20, T. 19 N, R. 6 E, Los Alamos County, $100 \mathrm{ft}$ upstream from confluence of Starmer's Gulch and Pajarito Canyon, 0.5 mile south of LANL TA-22, Building 91.

Drainage Area. $1.03 \mathrm{mi}^{2}$.

Period of Record. March 1999 to September 30, 2006.

Revised Record. Drainage Area (this report).

Gage. Data logger with cellular telemetry. Elevation of gage is 7,377 ft above NGVD from GIS 9.1. Datum lowered $2 \mathrm{ft}$ on July 25, 2005.

Remarks. Water discharge records good, except for estimated daily discharges, which are poor.

Average Discharge. $6 \mathrm{yr}, 0.13 \mathrm{ft}^{3} / \mathrm{s}, 94$ acre- $\mathrm{ft} / \mathrm{yr}$.

Extremes for Period of Record. Maximum discharge $180 \mathrm{ft}^{3} / \mathrm{s}$, June 28, 2000, gage height $2.75 \mathrm{ft}$. No flow at times.

Extremes for Current Water Year. Maximum discharge $17 \mathrm{ft}^{3} / \mathrm{s}$, at $1230 \mathrm{~h}$, August 8, gage height $3.89 \mathrm{ft}$. Minimum daily $0.0 \mathrm{ft}^{3} / \mathrm{s}$, June 6-21.

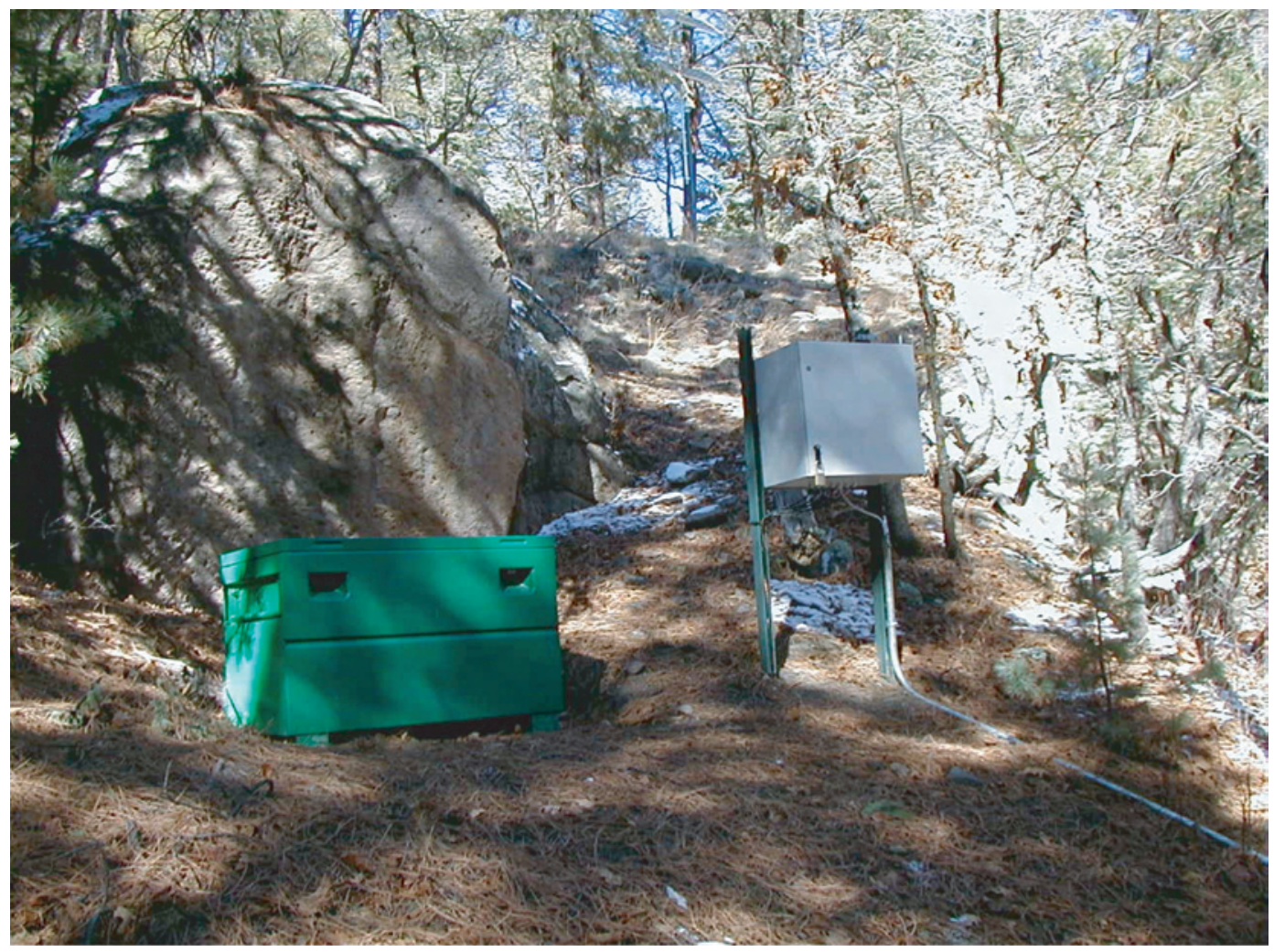




\section{E242 Starmers above Pajarito \\ Station Analysis \\ 2006 Water Year}

Equipment. Sutron 8210 data logger (5-min. interval) driven by a pressure bubbler system with a cellular telemetry housed in a NEMA shelter on right bank. The equipment is powered with a solar panel battery charging system; the station is also equipped with an ISCO pump sampler for water-quality data collection. The gage is reference to an enamel staff plate mounted in 4 in. channel on left bank, which also supports the bubbler orifice line. There is no provision for discharge measurement above wading stage.

Field Work. The station was visited twenty five times for the purpose of making a discharge measurement and/or servicing the instrumentation. Field inspections for the gage are listed under site history files on the Hydstra database. Discharge measurements for the gage are listed under site gauging files on the Hydstra database.

Datum Correction. Last levels run August 8, 2001, found gage reading within limits. A datum correction of $2.0 \mathrm{ft}$ was added when gage scour after flood of July, 2005.

Gage-Height Record. The data logger reference to the outside staff gave a complete and satisfactory record for the year.

Rating. The channel is about 13 feet wide and straight for about 100 feet upstream and straight for about 50 feet downstream, then bends to the left. The streambed through this reach is rock with cobbles. The right and left bank are covered with scrub oak and some conifers.

Rating No 3 was used all year. Stage application of shifts is illustrated by "V" diagrams and time application of shifts.

Ten discharge measurements (No. 35-44) were made at the gaging station this water year.

Discharge. Discharge was computed by applying Rating No. 3 direct with "V" diagrams. Discharge estimated due to ice effect was based on temperature and precipitation.

All measurements were low (less than $0.10 \mathrm{cfs}$ ) and checked using Rating 3 within $0.10 \mathrm{ft}$. of shift. Rating 3 is considered good.

Remarks. Records good except for estimated daily discharges, which are poor. 


\section{E242 Starmers above Pajarito}

Daily Mean Discharge in Cubic Feet per Second

Water Year October 2005 to September 2006

\begin{tabular}{|c|c|c|c|c|c|c|c|c|c|c|c|c|}
\hline DAY & OCT & NOV & DEC & JAN & FEB & MAR & APR & MAY & JUN & JUL & AUG & SEP \\
\hline 1 & .16 & .08 & .06 & .04 & .04 & .03 & .02 & .01 & .01 & .02 & .03 & .03 \\
\hline 2 & .16 & .08 & .05 & .04 & .04 & .03 & .02 & .01 & .01 & .02 & .03 & .02 \\
\hline 3 & .14 & .08 & .05 & .04 & .04 & .03 & .02 & .01 & .01 & .03 & .03 & .02 \\
\hline 4 & .11 & .09 & .09 & .04 & .04 & .03 & .02 & .01 & .01 & .03 & .03 & .02 \\
\hline 5 & .10 & .08 & .14 & .04 & .04 & .03 & .02 & .01 & .01 & .05 & .08 & .02 \\
\hline 6 & .08 & .08 & .20 & .04 & .04 & .03 & .02 & .01 & 0 & .04 & .07 & .02 \\
\hline 7 & .07 & .07 & .21 & .04 & .04 & .03 & .02 & .01 & 0 & .03 & .10 & .02 \\
\hline 8 & .07 & .07 & .19 & .04 & .04 & .03 & .02 & .01 & 0 & .03 & .28 & .02 \\
\hline 9 & .06 & .07 & .17 & .05 & .04 & .03 & .02 & .01 & 0 & .04 & .02 & .02 \\
\hline 10 & .07 & .06 & .12 & .04 & .04 & .02 & .02 & .01 & 0 & .03 & .02 & .02 \\
\hline 11 & .07 & .06 & .05 & .04 & .05 & .03 & .02 & .01 & 0 & .03 & .03 & .04 \\
\hline 12 & .07 & .06 & .04 & .04 & .05 & .03 & .02 & .01 & 0 & .03 & .03 & .02 \\
\hline 13 & .08 & .06 & .04 & .04 & .05 & .03 & .02 & .01 & 0 & .02 & .02 & .02 \\
\hline 14 & .08 & .06 & .04 & .04 & .04 & .03 & .02 & .01 & 0 & .02 & .02 & .02 \\
\hline 15 & .09 & .06 & .04 & .04 & .03 & .02 & .02 & .01 & 0 & .02 & .02 & .02 \\
\hline 16 & .09 & .06 & .04 & .04 & .03 & .02 & .02 & .01 & 0 & .02 & .02 & .02 \\
\hline 17 & .08 & .05 & .04 & .04 & .03 & .02 & .02 & .01 & 0 & .02 & .02 & .02 \\
\hline 18 & .08 & .05 & .04 & .04 & .03 & .02 & .02 & .01 & 0 & .02 & .02 & .02 \\
\hline 19 & .10 & .05 & .04 & .03 & .02 & .02 & .02 & .01 & 0 & .02 & .02 & .02 \\
\hline 20 & .09 & .05 & .04 & .04 & .02 & .02 & .02 & .01 & 0 & .02 & .04 & .02 \\
\hline 21 & .09 & .05 & .04 & .04 & .02 & .02 & .02 & .01 & 0 & .02 & .03 & .02 \\
\hline 22 & .10 & .05 & .04 & .04 & .03 & .02 & .02 & .01 & .01 & .02 & .03 & .02 \\
\hline 23 & .10 & .05 & .04 & .03 & .03 & .02 & .02 & .01 & .01 & .02 & .02 & .02 \\
\hline 24 & .10 & .04 & .04 & .03 & .03 & .02 & .02 & .01 & .01 & .02 & .02 & .02 \\
\hline 25 & .10 & .05 & .04 & .02 & .03 & .02 & .02 & .01 & .01 & .02 & .07 & .02 \\
\hline 26 & .10 & .05 & .04 & .02 & .03 & .02 & .01 & .01 & .01 & .02 & .02 & .02 \\
\hline 27 & .09 & .08 & .04 & .02 & .03 & .02 & .01 & .01 & .01 & .02 & .02 & .02 \\
\hline 28 & .09 & .16 & .04 & .03 & .03 & .02 & .02 & .01 & .02 & .02 & .02 & .02 \\
\hline 29 & .09 & .15 & .04 & .04 & ------ & .02 & .02 & .01 & .02 & .02 & .02 & .02 \\
\hline 30 & .09 & .06 & .04 & .04 & ----- & .02 & .01 & .01 & .02 & .03 & .02 & .02 \\
\hline 31 & .09 & ----- & .04 & .04 & ----- & .02 & ----- & .01 & ---- & .03 & .02 & ----- \\
\hline Total & 2.89 & 2.06 & 2.13 & 1.15 & 0.98 & 0.75 & 0.57 & 0.31 & 0.17 & 0.78 & 1.22 & 0.63 \\
\hline Mean & .093 & .069 & .069 & .037 & .035 & .024 & .019 & .010 & .006 & .025 & .039 & .021 \\
\hline Max & .16 & .16 & .21 & .05 & .05 & .03 & .02 & .01 & .02 & .05 & .28 & .04 \\
\hline Min & .06 & .04 & .04 & .02 & .02 & .02 & .01 & .01 & 0 & .02 & .02 & .02 \\
\hline Acre-Ft & 5.7 & 4.1 & 4.2 & 2.3 & 1.9 & 1.5 & 1.1 & .61 & .34 & 1.5 & 2.4 & 1.2 \\
\hline Wtr Year & 2006 & Total & 13.64 & & .03 & & lax & 8 & Min & & Acre-Ft & 27 \\
\hline Cal Year & 2005 & Total & 181.18 & & .50 & & lax & & Min & .03 & Acre-Ft & 359 \\
\hline
\end{tabular}




\section{E2425 La Delfe above Pajarito}

Location. Lat. 35 51'25", long. 106 $19^{\prime} 56^{\prime \prime}$, Ramon Vigil Grant, Los Alamos County 0.25 mile west of Starmer's Gulch and Pajarito Canyon and 0.75 mile south of LANL TA-22, Building 91.

Drainage Area. $0.15 \mathrm{mi}^{2}$.

Period of Record. June 1, 2000, to September 30, 2006.

Revised Record. Drainage Area (this report).

Gage. Data logger with cellular telemetry and $90^{\circ}$ sharp crested weir. Elevation of gage is 7,311 ft above NGVD from GIS 9.1.

Remarks. Water discharge records good, except for estimated daily discharges, which are poor.

Average Discharge, $6 \mathrm{yr}, 0.04 \mathrm{ft}^{3} / \mathrm{s}, 29$ acre- $\mathrm{ft} / \mathrm{yr}$.

Extremes for Period of Record. Maximum discharge $30 \mathrm{ft}^{3} / \mathrm{s}$, August 24, 2005, gage height $2.64 \mathrm{ft}$; no flow at times.

Extremes for Current Year. Maximum discharge $12 \mathrm{ft}^{3} / \mathrm{s}$ at $1410 \mathrm{~h}$, August 25, gage height $2.21 \mathrm{ft}$. No flow most of time.

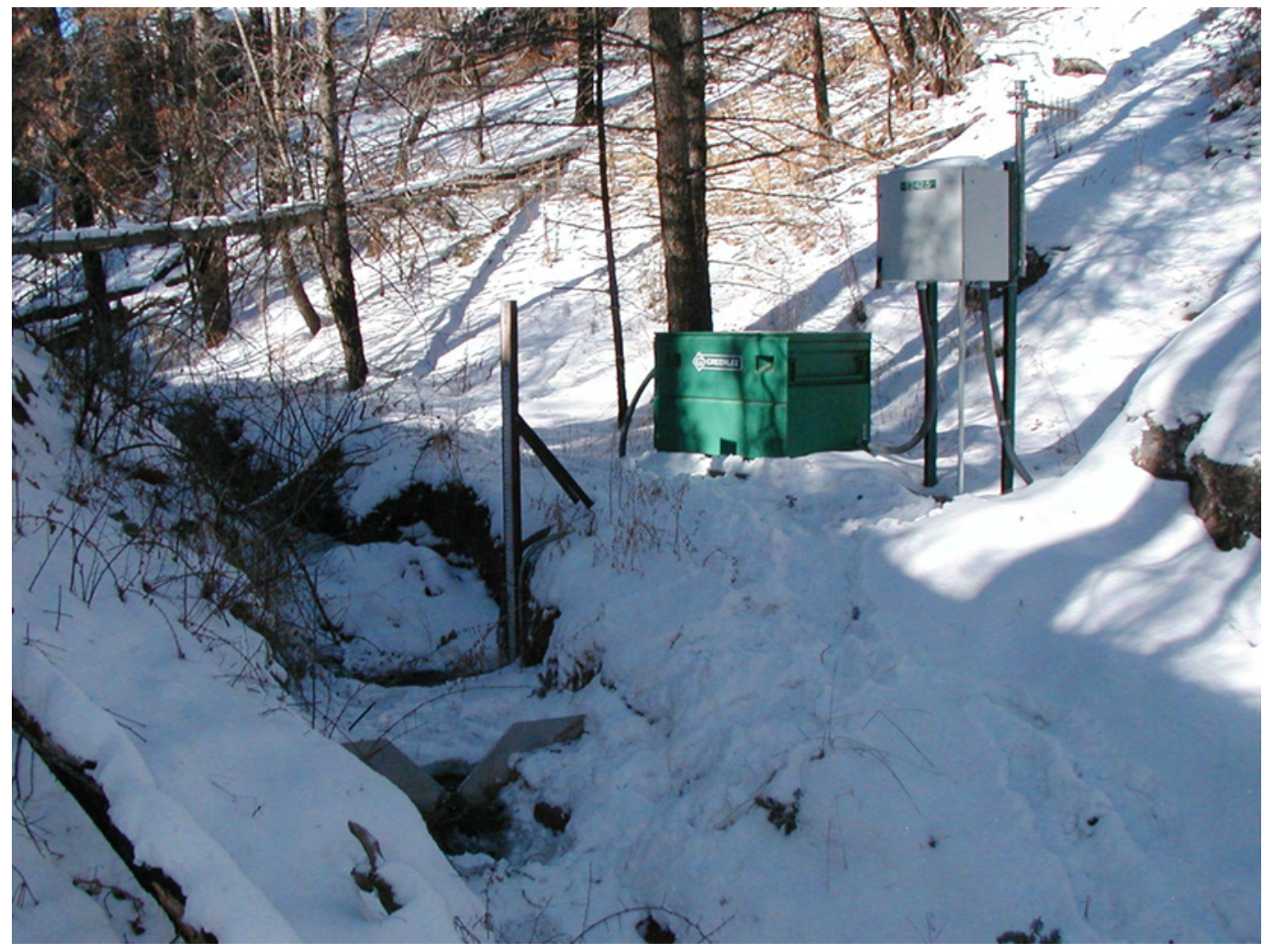




\section{E2425 La Delfe above Pajarito \\ Station Analysis \\ 2006 Water Year}

Equipment. Sutron 8210 data logger with cellular telemetry in NEMA shelter. Auxiliary shelter houses ISCO model 3700 automatic samplers that are triggered by the data logger. Stage sensor is Sutron self-contained bubble gage referenced to the outside staff gage. Control is 90-degree weir plate. No provision for measurements above wading stage, but that occurrence is not likely.

Field Work. The station was visited fourteen times for the purpose of making a discharge measurement and/or servicing the instrumentation. Field inspections for the gage are listed under site history files on the Hydstra database. Discharge measurements for the gage are listed under site gauging files on the Hydstra database.

Datum Correction. None.

Gage-Height Record. Gage height record is complete. Orifice partially froze a few days but cleaned itself out.

Rating. Channel is straight and narrow above and below gage. Bed material is sand and course gravel.

Rating 1 was continued in use. Debris in gage pool caused fairly large negative shifts $(0.20-0.40)$.

These were defined by discharge measurements 11-17 made this water year and no. 18 made subsequently used for this analysis.

"V" diagrams were used to apply shift but nothing but low flow occurred during the shifting period.

Maintenance on weir notch and gage pool on July 17 eliminated the negative shift. Measurement no. 18 made on October 14, 2006, confirmed the change.

Discharge. Computed using Rating No.1 and variable shift diagrams. The shift diagrams are available in Hydstra.

Remarks. Records good, except for estimated daily discharges, which are poor. 


\section{E2425 La Delfe above Pajarito}

Daily Mean Discharge in Cubic Feet per Second

Water Year October 2005 to September 2006

\begin{tabular}{|c|c|c|c|c|c|c|c|c|c|c|c|c|}
\hline DAY & OCT & NOV & DEC & JAN & FEB & MAR & APR & MAY & JUN & JUL & AUG & SEP \\
\hline 1 & .17 & .03 & .01 & .01 & 0 & 0 & .02 & 0 & 0 & 0 & .01 & .17 \\
\hline 2 & .12 & .03 & .01 & .01 & 0 & 0 & .02 & 0 & 0 & 0 & 0 & .08 \\
\hline 3 & .12 & .03 & 0 & .01 & 0 & 0 & .02 & 0 & 0 & 0 & 0 & .06 \\
\hline 4 & .12 & .03 & .01 & .01 & 0 & 0 & .02 & 0 & 0 & 0 & 0 & .04 \\
\hline 5 & .11 & .03 & .02 & .01 & 0 & 0 & .05 & 0 & 0 & 0 & .01 & .04 \\
\hline 6 & .10 & .03 & .02 & 0 & 0 & 0 & .06 & 0 & 0 & 0 & .02 & .04 \\
\hline 7 & .09 & .02 & .01 & 0 & 0 & 0 & .06 & 0 & .01 & 0 & .02 & .04 \\
\hline 8 & .09 & .02 & .01 & 0 & 0 & 0 & .05 & 0 & 0 & 0 & .35 & .04 \\
\hline 9 & .09 & .02 & .01 & 0 & 0 & .01 & .05 & 0 & 0 & 0 & .07 & .03 \\
\hline 10 & .09 & .02 & .01 & 0 & 0 & .02 & .05 & 0 & 0 & 0 & .04 & .03 \\
\hline 11 & .09 & .02 & .02 & 0 & 0 & .01 & .05 & 0 & 0 & 0 & .04 & .26 \\
\hline 12 & .08 & .02 & .01 & 0 & 0 & .01 & .05 & 0 & 0 & 0 & .03 & .08 \\
\hline 13 & .08 & .02 & .01 & 0 & 0 & .01 & .05 & 0 & .01 & 0 & .04 & .05 \\
\hline 14 & .07 & .02 & .02 & 0 & 0 & .05 & .04 & 0 & .02 & 0 & .04 & .04 \\
\hline 15 & .07 & .02 & .01 & 0 & 0 & .09 & .04 & 0 & .02 & 0 & .04 & .04 \\
\hline 16 & .07 & .02 & .02 & 0 & 0 & .05 & .04 & 0 & .02 & 0 & .04 & .03 \\
\hline 17 & .07 & .01 & .01 & 0 & 0 & .06 & .03 & 0 & .04 & 0 & .03 & .03 \\
\hline 18 & .06 & .01 & .01 & 0 & 0 & .04 & .02 & 0 & .04 & 0 & .04 & .03 \\
\hline 19 & .07 & .01 & .01 & 0 & 0 & .04 & 0 & 0 & .04 & 0 & .04 & .03 \\
\hline 20 & .06 & .01 & 0 & 0 & 0 & .02 & 0 & .01 & .04 & 0 & .05 & .03 \\
\hline 21 & .06 & .01 & 0 & 0 & 0 & .02 & 0 & 0 & .06 & 0 & .09 & .03 \\
\hline 22 & .06 & .01 & 0 & 0 & 0 & .02 & 0 & 0 & 0 & 0 & .06 & .03 \\
\hline 23 & .05 & .01 & 0 & 0 & 0 & .02 & 0 & .01 & 0 & 0 & .05 & .03 \\
\hline 24 & .05 & .01 & .01 & 0 & 0 & .02 & 0 & 0 & 0 & 0 & .05 & .03 \\
\hline 25 & .04 & .01 & .01 & 0 & 0 & .02 & 0 & 0 & 0 & 0 & .71 & .03 \\
\hline 26 & .04 & .01 & .01 & 0 & 0 & .01 & 0 & 0 & 0 & 0 & .20 & .02 \\
\hline 27 & .04 & .01 & 0 & 0 & 0 & .02 & 0 & 0 & 0 & 0 & .10 & .02 \\
\hline 28 & .04 & .01 & .01 & 0 & 0 & .02 & 0 & 0 & 0 & .01 & .07 & .02 \\
\hline 29 & .04 & .01 & .01 & 0 & ------ & .02 & 0 & 0 & 0 & .01 & .05 & .02 \\
\hline 30 & .03 & .01 & .01 & 0 & ------ & .02 & 0 & .01 & 0 & .01 & .05 & .02 \\
\hline 31 & .03 & --.-- & .01 & 0 & ------- & .02 & --.-- & 0 & ----- & 0 & .05 & ------ \\
\hline Total & 2.30 & 0.52 & 0.30 & 0.05 & 0 & 0.62 & 0.72 & 0.03 & 0.30 & 0.03 & 2.39 & 1.44 \\
\hline Mean & .074 & .017 & .010 & .002 & 0 & .020 & .024 & .001 & .010 & .001 & .077 & .048 \\
\hline Max & .17 & .03 & .02 & .01 & 0 & .09 & .06 & .01 & .06 & .01 & .71 & .26 \\
\hline Min & .03 & .01 & 0 & 0 & 0 & 0 & 0 & 0 & 0 & 0 & 0 & .02 \\
\hline Acre-Ft & 4.6 & 1.0 & .60 & .10 & 0 & 1.2 & 1.4 & .06 & .60 & .06 & 4.7 & 2.9 \\
\hline Wtr Year & 2006 & Total & 8.70 & Mean & .02 & & $\operatorname{Max}$ & .71 & Min & 0 & Acre-Ft & 17 \\
\hline Cal Year & 2005 & Total & 37.10 & Mean & .10 & & Max & .5 & Min & 0 & Acre-Ft & 74 \\
\hline
\end{tabular}




\section{E243 Pajarito above Two Mile}

Location. Lat. 35 51'14", long. 106¹7'48", Ramon Vigil Grant, Los Alamos County, on left bank, $200 \mathrm{ft}$ downstream above confluence of Two Mile Canyon, 0.6 mile upstream from E245, 1.0 mile upstream from E2455 and 2 miles from Pajarito Road.

Drainage Area. $4.24 \mathrm{mi}^{2}$.

Period of Record. February 2002 to September 30, 2006.

Revisions. Drainage Area (this report).

Gage. Data logger with cellular telemetry. Elevation of gage 6,941 ft above NGVD from GIS 9.1.

Remarks. Water discharge records good, except for estimated daily discharges, which are poor.

Extremes for Period of Record. Maximum discharge, $272 \mathrm{ft}^{3} / \mathrm{s}$, August 24, 2005, gage height $4.38 \mathrm{ft}$. No flow most time.

Extremes for Current Year. Maximum discharge, $101 \mathrm{ft}^{3} / \mathrm{s}$ at $1310 \mathrm{~h}$, August 8, gage height $2.99 \mathrm{ft}$. No flow at times.

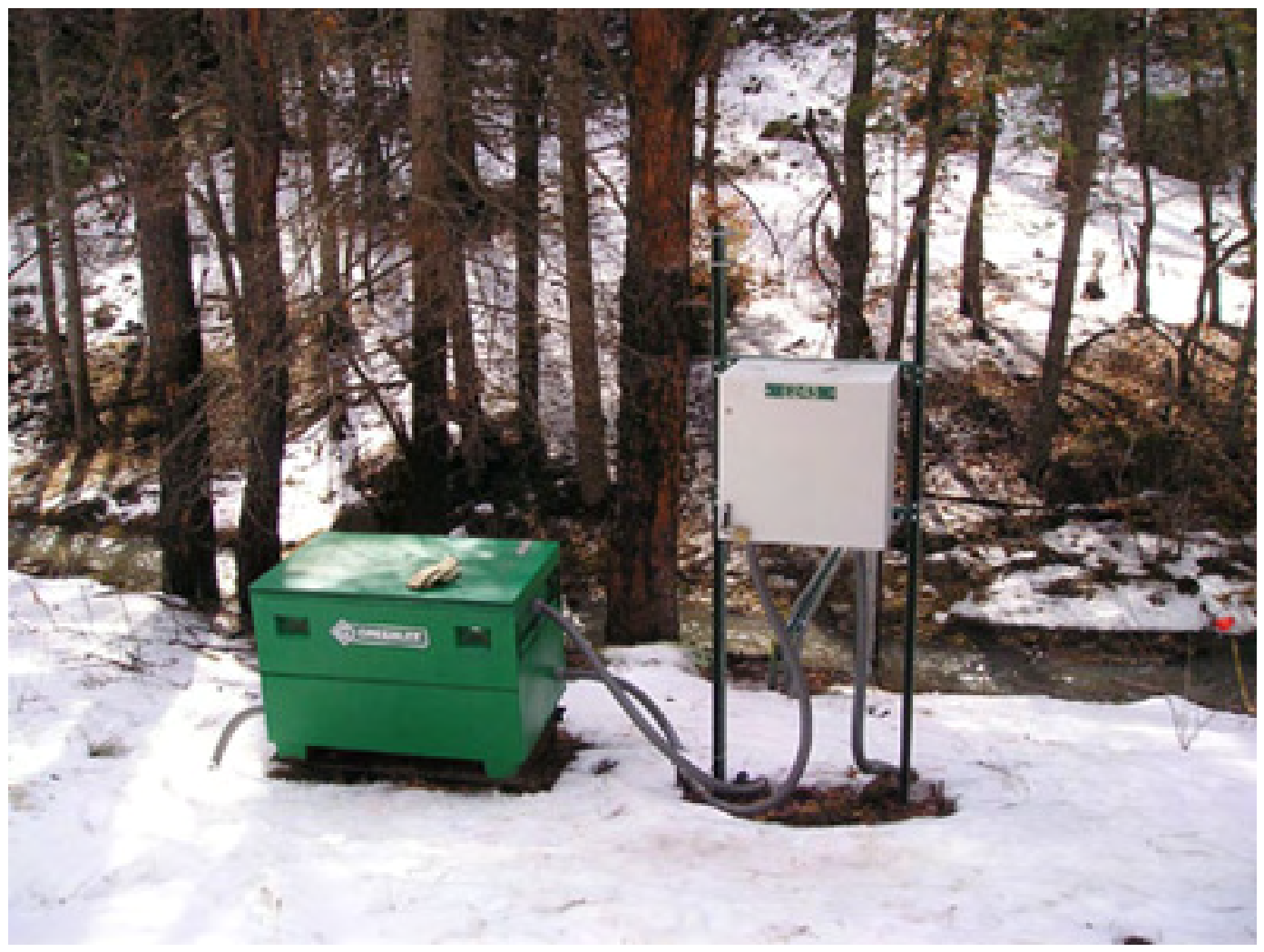




\section{E243 Pajarito above Two Mile \\ Station Analysis \\ 2006 Water Year}

Equipment. Sutron 8210 data logger (5-min. interval) with cellular phone and speech modem housed in a NEMA shelter on left bank. Bubble gage is sensing device and outside staff is reference gage. An ISCO-brand automatic sampler is stage-triggered by the data logger. Porcelain staff gage was available for outside reference until August 24. A steel post was installed September 1 on left bank to existing datum and was used as a reference point of 2.56 gage until gage reconstruction was accomplished in April 2006. No provision for direct measurement of flows above wading stage.

Field Work. The station was visited twenty five times for the purpose of making a discharge measurement and/or servicing the instrumentation. Field inspections for the gage are listed under site history files on the Hydstra database. Discharge measurements for the gage are listed under site gauging files on the Hydstra database.

Datum Correction. None from levels. On September 1, at same site, a datum correction of $1.0 \mathrm{ft}$ lower due to the scour in channel after the flood of August 24. Levels run, September 15, 2005, no corrections necessary. RM 1 was lost due to the flood of August 24. RM 2 was used to establish gage datum.

Gage-Height Record. The data logger gage height record was complete and satisfactory for the water year.

Rating. The channel is straight for 150 feet above and below gage. It is trapezoidal with the bed fairly well armored with large gravel and some cobbles. Banks are fairly well vegetated with grasses and should remain stable at all flows. Once it is well developed, the rating should be stable.

Rating 3 was redrawn based on low measurements (No. 16-20) and slope area of flood in 2005. Rating "back out" to left at top, but that is hydraulically most likely the case. Because rating 3 was never used for high flows, some of the upper points were just edited.

Discharge. Computed rating 3 with shift at low flow applied by "V" diagrams. Estimated zero flow in winter from icing of bubbler orifice. Stream was frozen dry.

Remarks. This station was originally at a site downstream about 0.5 mile. With the building of the Pajarito Flood Control Structure it had to be moved. That site was never rated and although gage height record is available in HYDSTA record for 1998-2002 will not be published. Record good, except for estimated daily discharges which are poor. 


\section{E243 Pajarito above Two Mile}

Daily Mean Discharge in Cubic Feet per Second

Water Year October 2005 to September 2006

\begin{tabular}{|c|c|c|c|c|c|c|c|c|c|c|c|c|}
\hline DAY & OCT & NOV & DEC & JAN & FEB & MAR & APR & MAY & JUN & JUL & AUG & SEP \\
\hline 1 & .72 & .17 & 0 & 0 & 0 & 0 & 0 & 0 & 0 & 0 & 0 & .82 \\
\hline 2 & .75 & .09 & 0 & 0 & 0 & 0 & 0 & 0 & 0 & 0 & 0 & .39 \\
\hline 3 & .69 & .04 & 0 & 0 & 0 & 0 & 0 & 0 & 0 & 0 & 0 & .29 \\
\hline 4 & .52 & .04 & 0 & 0 & 0 & 0 & 0 & 0 & 0 & 0 & 0 & .19 \\
\hline 5 & .40 & .01 & 0 & 0 & 0 & 0 & 0 & 0 & 0 & 0 & 0 & .15 \\
\hline 6 & .35 & .01 & 0 & 0 & 0 & 0 & 0 & 0 & 0 & 0 & 0 & .14 \\
\hline 7 & .30 & .01 & 0 & 0 & 0 & 0 & 0 & 0 & 0 & 0 & 0 & .14 \\
\hline 8 & .25 & .01 & 0 & 0 & 0 & 0 & 0 & 0 & 0 & 0 & 3.0 & .13 \\
\hline 9 & .22 & .01 & 0 & 0 & 0 & 0 & 0 & 0 & 0 & 0 & .13 & .12 \\
\hline 10 & .23 & .01 & 0 & 0 & 0 & 0 & 0 & 0 & 0 & 0 & .15 & .11 \\
\hline 11 & .22 & .01 & 0 & 0 & 0 & 0 & 0 & 0 & 0 & 0 & .17 & 1.4 \\
\hline 12 & .22 & 0 & 0 & 0 & 0 & 0 & 0 & 0 & 0 & 0 & .16 & .29 \\
\hline 13 & .28 & 0 & 0 & 0 & 0 & 0 & 0 & 0 & 0 & 0 & .15 & .17 \\
\hline 14 & .27 & 0 & 0 & 0 & 0 & 0 & 0 & 0 & 0 & 0 & .14 & .15 \\
\hline 15 & .27 & 0 & 0 & 0 & 0 & 0 & 0 & 0 & 0 & 0 & .14 & .13 \\
\hline 16 & .26 & 0 & 0 & 0 & 0 & 0 & 0 & 0 & 0 & 0 & .11 & .12 \\
\hline 17 & .24 & 0 & 0 & 0 & 0 & 0 & 0 & 0 & 0 & 0 & .11 & .11 \\
\hline 18 & .23 & 0 & 0 & 0 & 0 & 0 & 0 & 0 & 0 & 0 & .12 & .11 \\
\hline 19 & .26 & 0 & 0 & 0 & 0 & 0 & 0 & 0 & 0 & 0 & .17 & .11 \\
\hline 20 & .23 & 0 & 0 & 0 & 0 & 0 & 0 & 0 & 0 & 0 & .29 & .11 \\
\hline 21 & .21 & 0 & 0 & 0 & 0 & 0 & 0 & 0 & 0 & 0 & .34 & .11 \\
\hline 22 & .20 & 0 & 0 & 0 & 0 & 0 & 0 & 0 & 0 & 0 & .21 & .11 \\
\hline 23 & .19 & 0 & 0 & 0 & 0 & 0 & 0 & 0 & 0 & 0 & .17 & .11 \\
\hline 24 & .18 & 0 & 0 & 0 & 0 & 0 & 0 & 0 & 0 & 0 & .15 & .10 \\
\hline 25 & .12 & 0 & 0 & 0 & 0 & 0 & 0 & 0 & 0 & 0 & 6.5 & .10 \\
\hline 26 & .12 & 0 & 0 & 0 & 0 & 0 & 0 & 0 & 0 & 0 & .82 & .10 \\
\hline 27 & .11 & 0 & 0 & 0 & 0 & 0 & 0 & 0 & 0 & 0 & .35 & .10 \\
\hline 28 & .11 & 0 & 0 & 0 & 0 & 0 & 0 & 0 & 0 & 0 & .28 & .09 \\
\hline 29 & .10 & 0 & 0 & 0 & ------ & 0 & 0 & 0 & .08 & 0 & .26 & .09 \\
\hline 30 & .10 & 0 & 0 & 0 & ------ & 0 & 0 & 0 & 0 & 0 & .29 & .09 \\
\hline 31 & .09 & ----- & 0 & 0 & ----- & 0 & ------ & 0 & ----- & 0 & .23 & --.-- \\
\hline Total & 8.44 & 0.41 & 0 & 0 & 0 & 0 & 0 & 0 & 0.08 & 0 & 14.44 & 6.18 \\
\hline Mean & .27 & .014 & 0 & 0 & 0 & 0 & 0 & 0 & .003 & 0 & .47 & .21 \\
\hline Max & .75 & .17 & 0 & 0 & 0 & 0 & 0 & 0 & .08 & 0 & 6.5 & 1.4 \\
\hline Min & .09 & 0 & 0 & 0 & 0 & 0 & 0 & 0 & 0 & 0 & 0 & .09 \\
\hline Acre-Ft & 17 & .81 & 0 & 0 & 0 & 0 & 0 & 0 & .16 & 0 & 29 & 12 \\
\hline Wtr Year & 2006 & Total & 29.55 & Mean & .08 & & Max & 5 & Min & 0 & Acre-Ft & 59 \\
\hline Cal Year & 2005 & Total & 293.93 & Mean & .81 & & Max & & Min & 0 & Acre-Ft & 583 \\
\hline
\end{tabular}




\section{E2435 Two Mile Tributary at TA-3}

Location. Lat. 3552'08", long. 106'19'21", Sec 20, R06E, T19N in Ramon Vigil Grant, Los Alamos County, on right bank, 0.5 mile north of Pajarito Road.

Drainage Area. $0.02 \mathrm{mi}^{2}$.

Period of Record. October 1, 2005, to September 30, 2006

Revisions. Drainage Area (this report).

Gage. Data logger and 12" Parshall flume. Record for this existed before published period but not reliable. Elevation of gage is 7,402 ft above NGVD from GIS 9.1.

Remarks. Water discharge records good.

Extremes for Period of Record. Maximum discharge, $9.6 \mathrm{ft}^{3} / \mathrm{s}$, August 8, 2006, gage height $1.78 \mathrm{ft}$. No flow most time.

Extremes for Current Year. Maximum discharge, $9.6 \mathrm{ft}^{3} / \mathrm{s}$ at $1400 \mathrm{~h}$, August 8, gage height $1.78 \mathrm{ft}$. No flow most of the time.

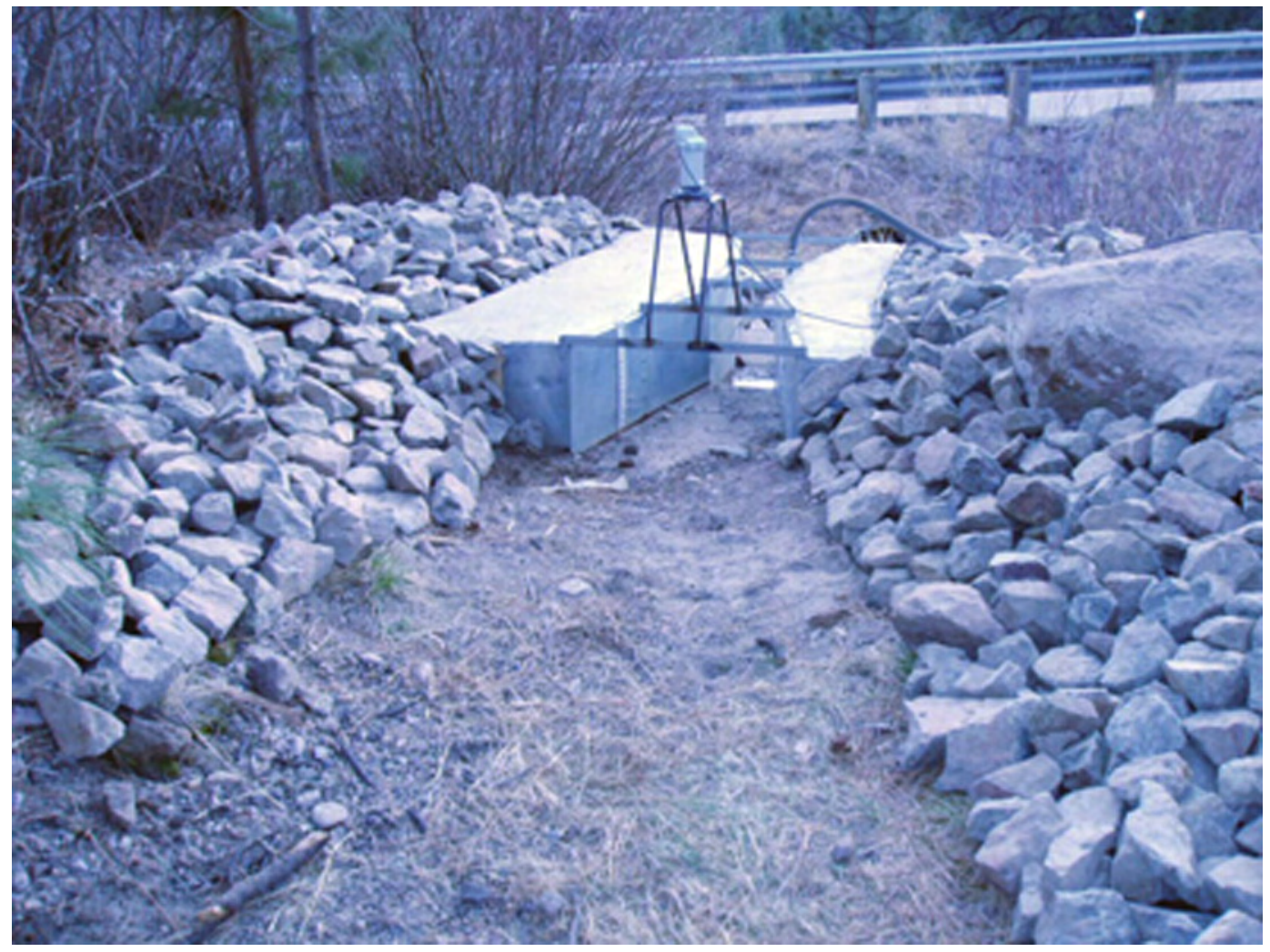




\section{E2435 Two Mile Tributary at TA-3 \\ Station Analysis \\ 2006 Water Year}

Equipment. This station was established in June of 2002 as a Geomation, until May 24, 2005, when Sutron 8210 data logger with cellular phone telemetry with speech modem with a solar panel battery charging system became housed in a NEMA shelter on right bank. A millitroncs sonic probe stage sensor is mounted on top a 12" Para shall flume. The gaging station is also equipped with an ISCO pump sampler for water-quality data collection and is housed in a separate shelter $4^{\prime} \times 4^{\prime}$ metal box, which is triggered by the data logger. The staff in the 12 " Parshall flume is the reference gage. There is no provision for direct discharge measurements above wading stage.

Field Work. The station was visited twelve times for the purpose of making a discharge measurement and/or servicing the instrumentation. Field inspections for the gage are listed under site history files on the Hydstra database. Discharge measurements for the gage are listed under site gauging files on the Hydstra database.

Datum Correction. None.

Gage-Height Record. The data logger referenced to the outside staff gave a complete and satisfactory record for the year; except during the period from October 1, 2005, to May 24, 2006, when gage height record was not complete due to transmission from the geomation to the home site being lost.

Rating. The channel is straight above and below gage. It is confined to the main channel by cut banks on both sides. The bottom is 10 feet wide channel prone to some shifting with vegetation on each bank. Low water control is the 12" Parshall flume.

Rating No. 1 was developed based on the computation of 12" Parshall flume. Point of zero flow is 0.00 gage height.

Twelve inspections of no flow were made this water year.

Discharge. Discharge was computed by applying Rating No. 1 direct.

Remarks. Records good, except for estimated daily discharges, which are poor. 


\section{E2435 Two Mile Tributary at TA-3}

Daily Mean Discharge in Cubic Feet per Second

Water Year October 2005 to September 2006

\begin{tabular}{|c|c|c|c|c|c|c|c|c|c|c|c|c|}
\hline DAY & OCT & NOV & DEC & JAN & FEB & MAR & APR & MAY & JUN & JUL & AUG & SEP \\
\hline 1 & 0 & 0 & 0 & 0 & 0 & 0 & 0 & 0 & 0 & 0 & .01 & .06 \\
\hline 2 & 0 & 0 & 0 & 0 & 0 & 0 & 0 & 0 & 0 & .02 & 0 & 0 \\
\hline 3 & 0 & 0 & 0 & 0 & 0 & 0 & 0 & 0 & 0 & .11 & 0 & 0 \\
\hline 4 & 0 & 0 & 0 & 0 & 0 & 0 & 0 & 0 & 0 & 0 & .03 & 0 \\
\hline 5 & 0 & 0 & 0 & 0 & 0 & 0 & .02 & 0 & 0 & .03 & .12 & 0 \\
\hline 6 & 0 & 0 & 0 & 0 & 0 & 0 & 0 & 0 & 0 & .05 & .04 & .05 \\
\hline 7 & 0 & 0 & 0 & 0 & 0 & 0 & 0 & 0 & 0 & 0 & .21 & 0 \\
\hline 8 & 0 & 0 & 0 & 0 & 0 & 0 & 0 & 0 & 0 & .06 & .18 & 0 \\
\hline 9 & .04 & 0 & 0 & 0 & 0 & 0 & 0 & 0 & 0 & .02 & 0 & 0 \\
\hline 10 & .01 & 0 & 0 & 0 & 0 & 0 & 0 & 0 & 0 & 0 & 0 & .01 \\
\hline 11 & 0 & 0 & 0 & 0 & 0 & 0 & 0 & 0 & 0 & 0 & 0 & .04 \\
\hline 12 & 0 & 0 & 0 & 0 & 0 & 0 & 0 & 0 & 0 & 0 & 0 & 0 \\
\hline 13 & 0 & 0 & 0 & 0 & 0 & 0 & 0 & 0 & 0 & 0 & .02 & 0 \\
\hline 14 & 0 & 0 & 0 & 0 & 0 & 0 & 0 & 0 & 0 & 0 & .04 & 0 \\
\hline 15 & 0 & 0 & 0 & 0 & 0 & 0 & 0 & 0 & 0 & 0 & 0 & .01 \\
\hline 16 & .01 & 0 & 0 & 0 & 0 & 0 & 0 & 0 & 0 & 0 & 0 & 0 \\
\hline 17 & 0 & 0 & 0 & 0 & 0 & 0 & 0 & 0 & 0 & 0 & 0 & 0 \\
\hline 18 & 0 & 0 & 0 & 0 & 0 & 0 & 0 & 0 & 0 & .04 & 0 & 0 \\
\hline 19 & .02 & 0 & 0 & 0 & 0 & 0 & 0 & 0 & 0 & 0 & .08 & 0 \\
\hline 20 & 0 & 0 & 0 & 0 & 0 & 0 & 0 & 0 & 0 & 0 & .05 & .02 \\
\hline 21 & 0 & 0 & 0 & 0 & 0 & 0 & 0 & 0 & 0 & .03 & 0 & 0 \\
\hline 22 & 0 & 0 & 0 & 0 & 0 & 0 & 0 & 0 & .09 & 0 & 0 & 0 \\
\hline 23 & 0 & 0 & 0 & 0 & 0 & 0 & 0 & 0 & 0 & 0 & 0 & 0 \\
\hline 24 & 0 & 0 & 0 & 0 & 0 & 0 & 0 & 0 & 0 & .02 & .01 & 0 \\
\hline 25 & 0 & 0 & 0 & 0 & 0 & 0 & 0 & 0 & .02 & 0 & .45 & 0 \\
\hline 26 & 0 & 0 & 0 & 0 & 0 & 0 & 0 & 0 & .01 & .01 & 0 & 0 \\
\hline 27 & 0 & 0 & 0 & 0 & 0 & 0 & 0 & 0 & 0 & 0 & .01 & 0 \\
\hline 28 & 0 & 0 & 0 & 0 & 0 & 0 & .36 & 0 & .04 & .03 & 0 & 0 \\
\hline 29 & 0 & 0 & 0 & 0 & ------ & 0 & .01 & 0 & .03 & 0 & 0 & 0 \\
\hline 30 & 0 & 0 & 0 & 0 & ------ & 0 & 0 & 0 & 0 & 0 & 0 & 0 \\
\hline 31 & 0 & ----- & 0 & 0 & ------ & 0 & ----- & 0 & ----- & .02 & 0 & ----- \\
\hline Total & 0.08 & 0 & 0 & 0 & 0 & 0 & 0.39 & 0 & 0.19 & 0.44 & 1.25 & 0.19 \\
\hline Mean & .003 & 0 & 0 & 0 & 0 & 0 & .013 & 0 & .006 & .014 & .040 & .006 \\
\hline Max & .04 & 0 & 0 & 0 & 0 & 0 & .36 & 0 & .09 & .11 & .45 & .06 \\
\hline Min & 0 & 0 & 0 & 0 & 0 & 0 & 0 & 0 & 0 & 0 & 0 & 0 \\
\hline Acre-Ft & .16 & 0 & 0 & 0 & 0 & 0 & .77 & 0 & .38 & .87 & 2.5 & .38 \\
\hline Wtr Year & 2006 & Total & 2.54 & Mear & .007 & & hax & .45 & Min & 0 & Acre-Ft & 5.0 \\
\hline Cal Year & 2005 & Total & 0.08 & Mear & .001 & & hax & .04 & Min & 0 & Acre-Ft & .16 \\
\hline
\end{tabular}




\section{E244 Two Mile above Pajarito}

Location. Lat. 35 51'15", long. 106 $17^{\prime} 46^{\prime \prime}$, in Ramon Vigil Grant, Los Alamos County, on left bank $300 \mathrm{ft}$ upstream from influence with Pajarito Canyon.

Drainage Area. $3.15 \mathrm{mi}^{2}$.

Period of Record. January 15, 2000, to September 30, 2006.

Revised Record. Drainage Area (this report).

Gage. Data logger with cellular telemetry. Elevation of gage is 6,940 ft above NGVD from GIS 9.1.

Remarks. Records fair, except for estimated daily discharges, which are poor.

Extremes for Period of Record. Maximum discharge $628 \mathrm{ft}^{3} / \mathrm{s}$, August 25, 2006, gage height $6.01 \mathrm{ft}$., ( from flood marks). No flow most of time.

Extremes for Current Water Year. Maximum discharge $628 \mathrm{ft}^{3} / \mathrm{s}$ at $1245 \mathrm{~h}$, August 25, gage height $6.01 \mathrm{ft}$ (from flood marks). No flow most of time.

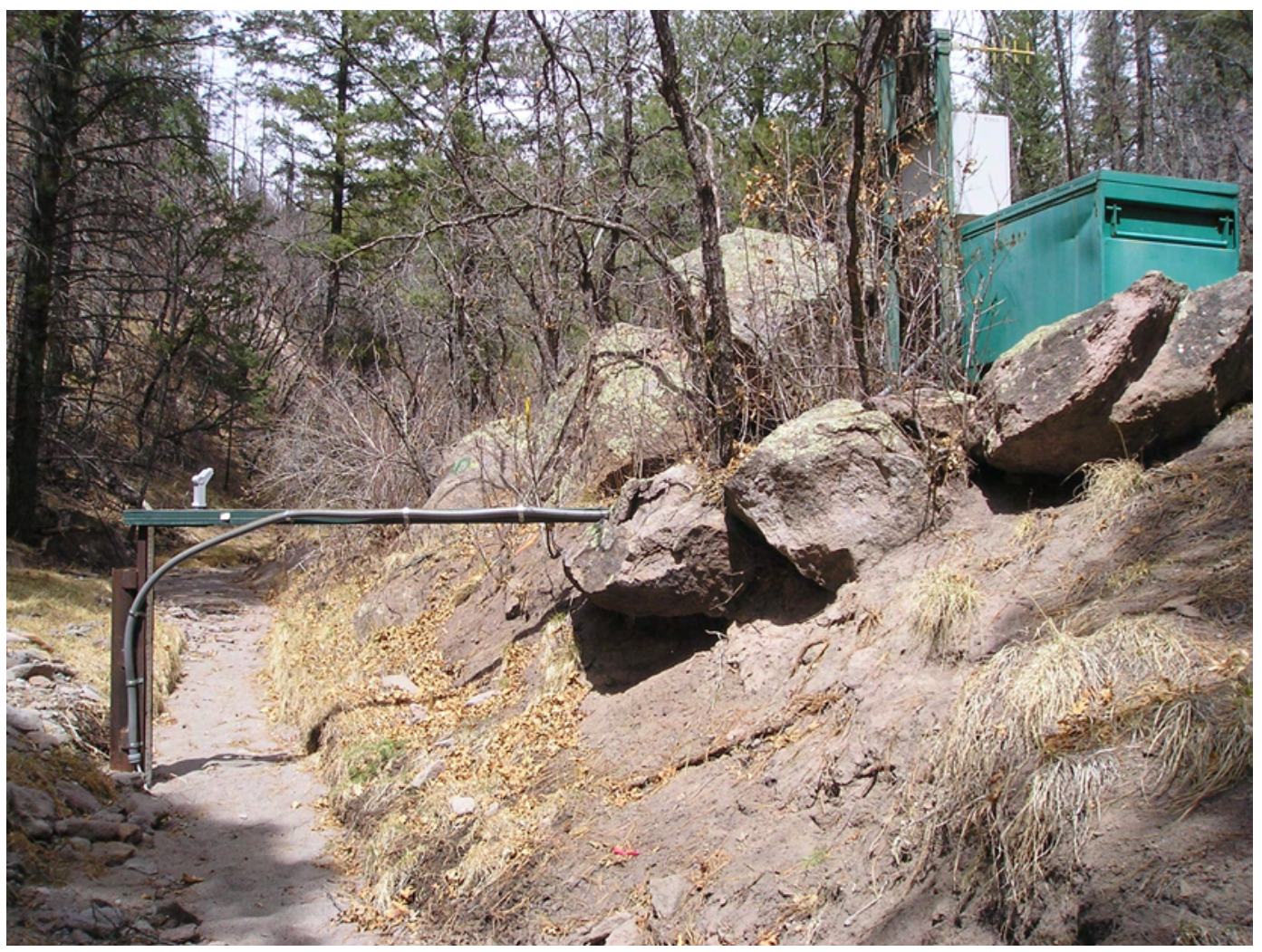




\section{E244 Two Mile above Pajarito \\ Station Analysis \\ 2006 Water Year}

Equipment. Sutron 8210 data logger (5-min. interval) with cellular phone and speech modem housed in a NEMA shelter. Stage sensor is milltronics sonic probe. ISCO samplers are housed in a separate shelter and are activated by stage through the data logger. An outside staff gage is available for reference. Wading measurements can be in the vicinity of the gage. No provision for measurement above wading stages.

Field Work. The station was visited twenty five times for the purpose of making a discharge measurement and/or servicing the instrumentation. Field inspections for the gage are listed under site history files on the Hydstra database. Discharge measurements for the gage are listed under site gauging files on the Hydstra database.

Datum Correction. None from levels. Some corrections applied as datum's, but they are really "pen" corrections. Gage reset by levels after destruction by flood in August 2006.

Gage-Height Record. Record lost June 30-July 5 and July 20-August 1. Remaining record was good and usable for computations.

Rating. The channel at the gage is straight for about 150 feet above gage and 50 feet below gage. Channel expands quite a bit below gage. Bed material is coarse sand and gravel. Banks are grassy with some small trees and outcrops affecting roughness at higher flows.

Rating 1 was continued in use with large -.45 shift at extreme low flows. Measurements 10, 11 defined the shifts. Shift diagrams distributed them by time/stage and no shift was used above 10 cfs.

Peak of record occurred on August 25 confirmed by flood mark. Rating 1 was extended by log plotting to $6.5 \mathrm{ft}$ stage.

Rating No. 1 is good to fair.

Discharge. Discharge was computed by applying Rating No. 1 using variable shift diagrams. Some periods have large shifts on lower end because of dry condition varying the PZF. Periods of lost record were estimated using weather records and comparison with E243 which is just downstream on Pajarito Canyon.

Remarks. Records fair, except for estimated daily discharges, which are poor. This station was operated at a site 200 feet downstream but never rated It had to be moved because that site is in backwater from Pajarito Flood Control structure which was built in 2000 just after the Cerro Grande Fire. 


\section{E244 Two Mile above Pajarito}

Daily Mean Discharge in Cubic Feet per Second

Water Year October 2005 to September 2006

\begin{tabular}{|c|c|c|c|c|c|c|c|c|c|c|c|c|}
\hline DAY & OCT & NOV & DEC & JAN & FEB & MAR & APR & MAY & JUN & JUL & AUG & SEP \\
\hline 1 & .32 & .06 & 0 & 0 & 0 & 0 & 0 & 0 & 0 & $0^{*}$ & $.35^{*}$ & .19 \\
\hline 2 & .25 & .05 & 0 & 0 & 0 & 0 & 0 & 0 & 0 & $0^{*}$ & 0 & 0 \\
\hline 3 & .24 & .04 & 0 & 0 & 0 & 0 & 0 & 0 & 0 & $0^{*}$ & .21 & 0 \\
\hline 4 & .26 & .03 & 0 & 0 & 0 & 0 & 0 & 0 & 0 & $0^{*}$ & .27 & 0 \\
\hline 5 & .23 & .03 & 0 & 0 & 0 & 0 & 0 & 0 & 0 & $0^{*}$ & .36 & 0 \\
\hline 6 & .21 & .06 & 0 & 0 & 0 & 0 & 0 & 0 & 0 & 0 & .26 & .02 \\
\hline 7 & .18 & .07 & 0 & 0 & 0 & 0 & 0 & 0 & 0 & 0 & .94 & 0 \\
\hline 8 & .17 & .09 & 0 & 0 & 0 & 0 & 0 & 0 & 0 & 0 & 5.0 & 0 \\
\hline 9 & .22 & .09 & 0 & 0 & 0 & 0 & 0 & 0 & 0 & 0 & .30 & 0 \\
\hline 10 & .26 & .09 & 0 & 0 & 0 & 0 & 0 & 0 & 0 & 0 & .14 & 0 \\
\hline 11 & .22 & .10 & 0 & 0 & 0 & 0 & 0 & 0 & 0 & 0 & .11 & 0 \\
\hline 12 & .24 & .08 & 0 & 0 & 0 & 0 & 0 & .01 & 0 & 0 & .10 & 0 \\
\hline 13 & .24 & .08 & 0 & 0 & 0 & 0 & 0 & .01 & 0 & 0 & .12 & 0 \\
\hline 14 & .24 & .09 & 0 & 0 & 0 & 0 & 0 & 0 & 0 & 0 & .20 & 0 \\
\hline 15 & .28 & .07 & 0 & 0 & 0 & 0 & 0 & 0 & 0 & 0 & .18 & 0 \\
\hline 16 & .23 & .07 & 0 & 0 & 0 & 0 & 0 & 0 & 0 & 0 & .06 & 0 \\
\hline 17 & .21 & .07 & 0 & 0 & 0 & 0 & 0 & .01 & 0 & 0 & .03 & 0 \\
\hline 18 & .23 & .05 & 0 & 0 & 0 & 0 & 0 & .01 & 0 & 0 & .01 & 0 \\
\hline 19 & .26 & .04 & 0 & 0 & 0 & 0 & 0 & .01 & 0 & $0^{*}$ & .23 & .01 \\
\hline 20 & .20 & .05 & 0 & 0 & 0 & 0 & 0 & 0 & 0 & $0^{*}$ & .06 & .01 \\
\hline 21 & .20 & .07 & 0 & 0 & 0 & 0 & 0 & 0 & 0 & $0^{*}$ & .11 & .01 \\
\hline 22 & .20 & .04 & 0 & 0 & 0 & 0 & 0 & 0 & 0 & $0^{*}$ & .04 & .01 \\
\hline 23 & .18 & 0 & 0 & 0 & 0 & 0 & 0 & 0 & 0 & $0^{*}$ & .04 & .01 \\
\hline 24 & .16 & 0 & 0 & 0 & 0 & 0 & 0 & 0 & 0 & $0^{*}$ & .03 & .02 \\
\hline 25 & .16 & 0 & 0 & 0 & 0 & 0 & 0 & .01 & 0 & $0^{*}$ & 52 & .03 \\
\hline 26 & .14 & 0 & 0 & 0 & 0 & 0 & 0 & 0 & 0 & $0^{*}$ & 13 & .03 \\
\hline 27 & .13 & 0 & 0 & 0 & 0 & 0 & 0 & 0 & 0 & $0^{*}$ & 4.3 & .02 \\
\hline 28 & .11 & 0 & 0 & 0 & 0 & 0 & 0 & 0 & 0 & $0^{*}$ & 3.1 & .03 \\
\hline 29 & .11 & 0 & 0 & 0 & ----- & 0 & 0 & 0 & 0 & $0^{*}$ & .98 & .09 \\
\hline 30 & .07 & 0 & 0 & 0 & ---- & 0 & 0 & 0 & $0^{*}$ & $0^{*}$ & 1.4 & .15 \\
\hline 31 & .06 & ----- & 0 & 0 & ---- & 0 & ------ & 0 & ----- & $0^{*}$ & .12 & ----- \\
\hline Total & 6.21 & 1.42 & 0 & 0 & 0 & 0 & 0 & 0.06 & 0 & 0 & 84.05 & 0.63 \\
\hline Mean & .20 & .047 & 0 & 0 & 0 & 0 & 0 & .002 & 0 & 0 & 2.71 & .021 \\
\hline $\operatorname{Max}$ & .32 & .10 & 0 & 0 & 0 & 0 & 0 & .01 & 0 & 0 & 52 & .19 \\
\hline Min & .06 & 0 & 0 & 0 & 0 & 0 & 0 & 0 & 0 & 0 & 0 & 0 \\
\hline Acre-Ft & 12 & 2.8 & 0 & 0 & 0 & 0 & 0 & .12 & 0 & 0 & 167 & 1.2 \\
\hline Wtr Year & 2006 & Total & 92.37 & Mean & & .25 & Max & 52 & Min & 0 & Acre-Ft & 183 \\
\hline Cal Year & 2005 & Total & 66.33 & Mean & & .18 & Max & 22 & Min & 0 & Acre-Ft & 132 \\
\hline
\end{tabular}




\section{E245 Pajarito above TA-18}

Location. Lat. 35 51'4", long. 106 17'11", Ramon Vigil Grant, Los Alamos County, on left bank 0.15 mile southeast of Pajarito Road, and upstream from LANL TA-8 and Three Mile Canyon.

Drainage Area. $7.56 \mathrm{mi}^{2}$.

Period of Record. November 1993 to September 30, 2006.

Revisions. Drainage Area (this report).

Gage. Data logger with cellular telemetry and concrete control. Elevation of gage is $6,880 \mathrm{ft}$ above NGVD from GIS 9.1.

Remarks. Water discharge records good, except for estimated daily discharges, which are poor.

Average Discharge. $12 \mathrm{yr}, 0.19 \mathrm{ft}^{3} / \mathrm{s}, 138$ acre-ft/yr.

Extremes for Period of Record. Maximum discharge $517 \mathrm{ft}^{3} / \mathrm{s}$, June 28, 2000, gage height $5.03 \mathrm{ft}$ (from flood mark). No flow most of time.

Extremes for Current Water Year. Maximum discharge $425 \mathrm{ft}^{3} / \mathrm{s}$ at $1315 \mathrm{~h}$, August 25, gage height $5.10 \mathrm{ft}$ (from flood mark). No flow most of time.

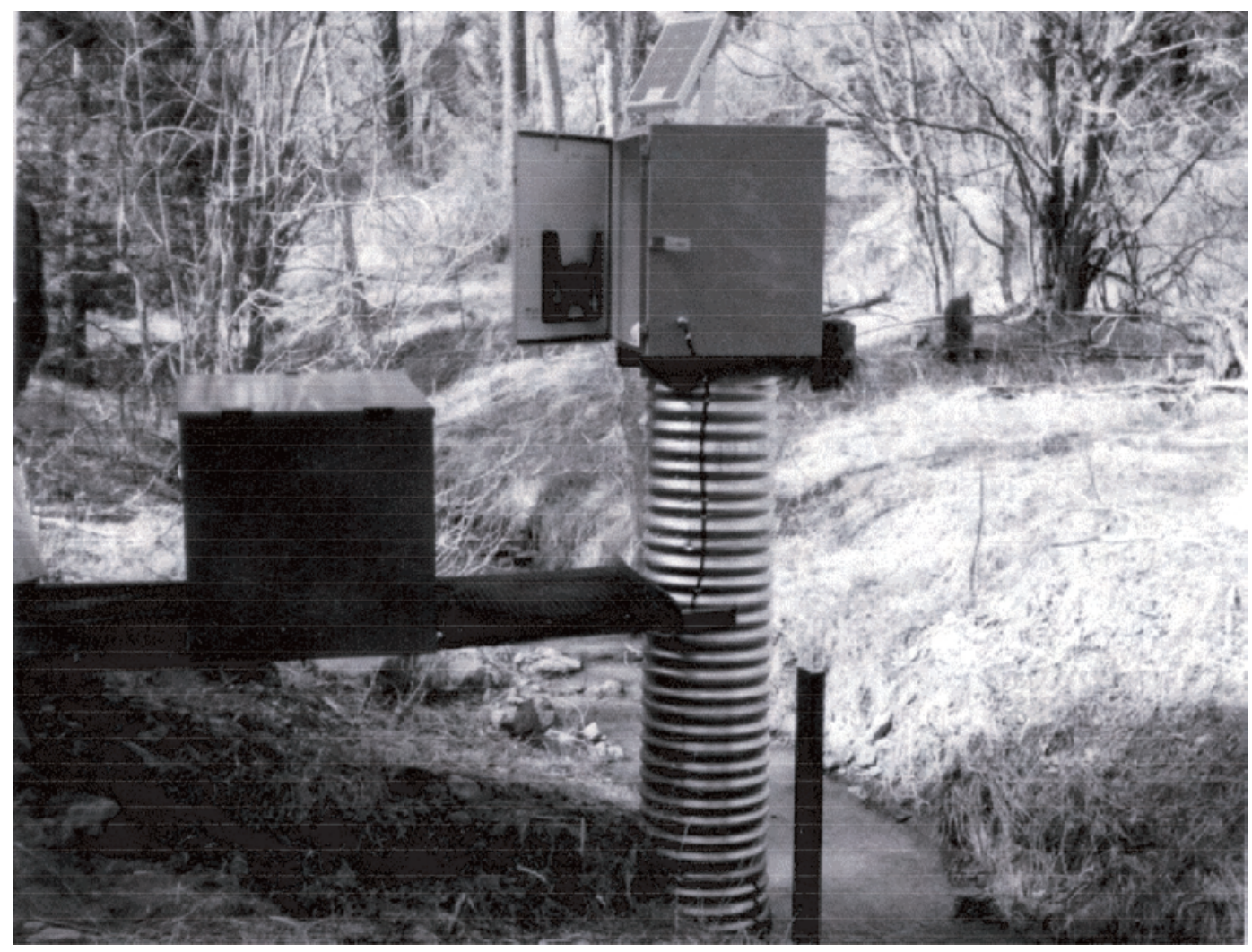




\section{E245 Pajarito above TA-18 \\ Station Analysis \\ 2006 Water Year}

Equipment. Sutron 8210 data logger in NEMA shelter on 18" CMP well on right bank. Instrument is equipped with cellular telemetry. Auxiliary shelters are available for automatic samplers. Outside staff and electric taper are reference gages. No provision for direct discharge measurements above wading stages.

Field Work. The station was visited sixteen times for the purpose of making a discharge measurement and/or servicing the instrumentation. Field inspections for the gage are listed under site history files on the Hydstra database. Discharge measurements for the gage are listed under site gauging files on the Hydstra database.

\section{Datum Correction. None.}

Gage-Height Record. Data were lost April 28 to August 3 when data logger failed. That active period was zero flow. Logger failed again August 16-27. Remainder of the year was good record.

Rating. The channel is straight for 100 feet above and below gage. Bed material is gravel with fine-sand movement during flow events. Control is concrete broad-crested weir.

Rating No. 2 was used all year.

No discharge measurements were made.

One critical depth computation was done on peak flow of August 25.

Discharge. Computed from rating 2 using "V" shift diagrams.

August 25 was peak of year and was computed manually using HWM and critical depth computation. Shift of -.30 was applied on peak based on that computation. Being left of the rating, it is considered to be result of vegetation causing higher " $N$ " values. Long period of lost record was estimated at zero flow based on precipitation and nearby gaging stations.

Remarks. Records good, except for estimated daily discharges, which are fair. 
E245 Pajarito above TA-18

Daily Mean Discharge in Cubic Feet per Second

Water Year October 2005 to September 2006

\begin{tabular}{|c|c|c|c|c|c|c|c|c|c|c|c|c|}
\hline DAY & OCT & NOV & DEC & JAN & FEB & MAR & APR & MAY & JUN & JUL & AUG & SEP \\
\hline 1 & .28 & 0 & 0 & 0 & 0 & 0 & 0 & $0^{*}$ & $0^{*}$ & $0^{*}$ & 0 & 2.2 \\
\hline 2 & .28 & 0 & 0 & 0 & 0 & 0 & 0 & $0^{*}$ & $0^{*}$ & $0^{*}$ & 0 & 1.1 \\
\hline 3 & .28 & 0 & 0 & 0 & 0 & 0 & 0 & $0^{*}$ & $0^{*}$ & $0^{*}$ & 0 & .71 \\
\hline 4 & .28 & 0 & 0 & 0 & 0 & 0 & 0 & $0^{*}$ & $0^{*}$ & $0^{*}$ & 0 & .30 \\
\hline 5 & .24 & 0 & 0 & 0 & 0 & 0 & 0 & $0^{*}$ & $0^{*}$ & $0^{*}$ & 0 & .01 \\
\hline 6 & .18 & 0 & 0 & 0 & 0 & 0 & 0 & $0^{*}$ & $0^{*}$ & $0^{*}$ & 0 & .11 \\
\hline 7 & .10 & 0 & 0 & 0 & 0 & 0 & 0 & $0^{*}$ & $0^{*}$ & $0^{*}$ & .13 & .16 \\
\hline 8 & .05 & 0 & 0 & 0 & 0 & 0 & 0 & $0^{*}$ & $0^{*}$ & $0^{*}$ & 7.9 & 0 \\
\hline 9 & .08 & 0 & 0 & 0 & 0 & 0 & 0 & $0^{*}$ & $0^{*}$ & $0^{*}$ & .11 & 0 \\
\hline 10 & .10 & 0 & 0 & 0 & 0 & 0 & 0 & $0^{*}$ & $0^{*}$ & $0^{*}$ & .07 & 0 \\
\hline 11 & .07 & 0 & 0 & 0 & 0 & 0 & 0 & $0^{*}$ & $0^{*}$ & $0^{*}$ & .07 & 2.4 \\
\hline 12 & .04 & 0 & 0 & 0 & 0 & 0 & 0 & $0^{*}$ & $0^{*}$ & $0^{*}$ & .07 & .68 \\
\hline 13 & .04 & 0 & 0 & 0 & 0 & 0 & 0 & $0^{*}$ & $0^{*}$ & $0^{*}$ & .07 & .10 \\
\hline 14 & .04 & 0 & 0 & 0 & 0 & 0 & 0 & $0^{*}$ & $0^{*}$ & $0^{*}$ & .07 & 0 \\
\hline 15 & .12 & 0 & 0 & 0 & 0 & 0 & 0 & $0^{*}$ & $0^{*}$ & $0^{*}$ & $0^{*}$ & 0 \\
\hline 16 & .10 & 0 & 0 & 0 & 0 & 0 & 0 & $0^{*}$ & $0^{*}$ & $0^{*}$ & $0^{*}$ & 0 \\
\hline 17 & .03 & 0 & 0 & 0 & 0 & 0 & 0 & $0^{*}$ & $0^{*}$ & $0^{*}$ & $0^{*}$ & 0 \\
\hline 18 & .02 & 0 & 0 & 0 & 0 & 0 & 0 & $0^{*}$ & $0^{*}$ & $0^{*}$ & $0^{*}$ & 0 \\
\hline 19 & .18 & 0 & 0 & 0 & 0 & 0 & 0 & $0^{*}$ & $0^{*}$ & $0^{*}$ & $0^{*}$ & 0 \\
\hline 20 & .06 & 0 & 0 & 0 & 0 & 0 & 0 & $0^{*}$ & $0^{*}$ & $0^{*}$ & $0^{*}$ & 0 \\
\hline 21 & .03 & 0 & 0 & 0 & 0 & 0 & 0 & $0^{*}$ & $0^{*}$ & $0^{*}$ & $0^{*}$ & 0 \\
\hline 22 & .03 & 0 & 0 & 0 & 0 & 0 & 0 & $0^{*}$ & $0^{*}$ & $0^{*}$ & $0^{*}$ & 0 \\
\hline 23 & .02 & 0 & 0 & 0 & 0 & 0 & 0 & $0^{*}$ & $0^{*}$ & $0^{*}$ & $0^{*}$ & 0 \\
\hline 24 & 0 & 0 & 0 & 0 & 0 & 0 & 0 & $0^{*}$ & $0^{*}$ & $0^{*}$ & $0^{*}$ & 0 \\
\hline 25 & 0 & 0 & 0 & 0 & 0 & 0 & 0 & $0^{*}$ & $0^{*}$ & $0^{*}$ & $30^{*}$ & 0 \\
\hline 26 & 0 & 0 & 0 & 0 & 0 & 0 & 0 & $0^{*}$ & $0^{*}$ & $0^{*}$ & $1.7^{*}$ & 0 \\
\hline 27 & 0 & 0 & 0 & 0 & 0 & 0 & 0 & $0^{*}$ & $0^{*}$ & $0^{*}$ & 1.5 & 0 \\
\hline 28 & 0 & 0 & 0 & 0 & 0 & 0 & $0^{*}$ & $0^{*}$ & $0^{*}$ & $0^{*}$ & 1.4 & 0 \\
\hline 29 & 0 & 0 & 0 & 0 & ------ & 0 & $0^{*}$ & $0^{*}$ & $0^{*}$ & $0^{*}$ & 1.3 & 0 \\
\hline 30 & 0 & 0 & 0 & 0 & ------ & 0 & $0^{*}$ & $0^{*}$ & $0^{*}$ & $0^{*}$ & 1.2 & 0 \\
\hline 31 & 0 & ----- & 0 & 0 & ----- & 0 & ----- & $0^{*}$ & ----- & $0^{*}$ & .98 & ---- \\
\hline Total & 2.65 & 0 & 0 & 0 & 0 & 0 & 0 & 0 & 0 & 0 & 46.57 & 7.77 \\
\hline Mean & .085 & 0 & 0 & 0 & 0 & 0 & 0 & 0 & 0 & 0 & 1.50 & .26 \\
\hline Max & .28 & 0 & 0 & 0 & 0 & 0 & 0 & 0 & 0 & 0 & 30 & 2.4 \\
\hline Min & 0 & 0 & 0 & 0 & 0 & 0 & 0 & 0 & 0 & 0 & 0 & 0 \\
\hline Acre-Ft & 5.3 & 0 & 0 & 0 & 0 & 0 & 0 & 0 & 0 & 0 & 92 & 15 \\
\hline Wtr Year & 2006 & Total & 56.99 & Mean & .16 & & Max & 30 & Min & 0 & Acre-Ft & 113 \\
\hline Cal Year & 2005 & Total & 325.06 & Mean & .89 & & Max & 29 & Min & 0 & Acre-Ft & 645 \\
\hline
\end{tabular}

* Estimated 


\section{E246 Three Mile above Pajarito}

Location. Lat. 3550'20", long. 106¹6'17", NW 1/4 SE 1/4, Ramon Vigil Grant, Los Alamos County, 0.05 mile northeast of TA-18, and 0.50 mile southeast of Pajarito Road.

Drainage Area. $1.62 \mathrm{mi}^{2}$.

Period of Record. October 1998 to September 30, 2006.

Revised Record. Drainage Area (this report).

Gage. Data logger with cellular telemetry and 9-in. Parshall flume. Elevation of gage is 6,755 ft above NGVD from GIS 9.1.

Remarks. Water discharge record good, except for estimated daily discharges, which are poor.

Average Discharge. $8 \mathrm{yr}, 0.015 \mathrm{ft}^{3} / \mathrm{s}, 11$ acre- $\mathrm{ft} / \mathrm{yr}$.

Extremes for Period of Record. Maximum discharge $536 \mathrm{ft}^{3} / \mathrm{s}$, August 25, 2006, gage height $3.50 \mathrm{ft}$, from critical depth computation of peak flow. No flow most of time.

Extremes for Current Water Year. Maximum discharge $536 \mathrm{ft}^{3} / \mathrm{s}$ at $1315 \mathrm{~h}$, August 25, gage height $3.50 \mathrm{ft}$., from critical depth computation of peak flow. No flow most of time.

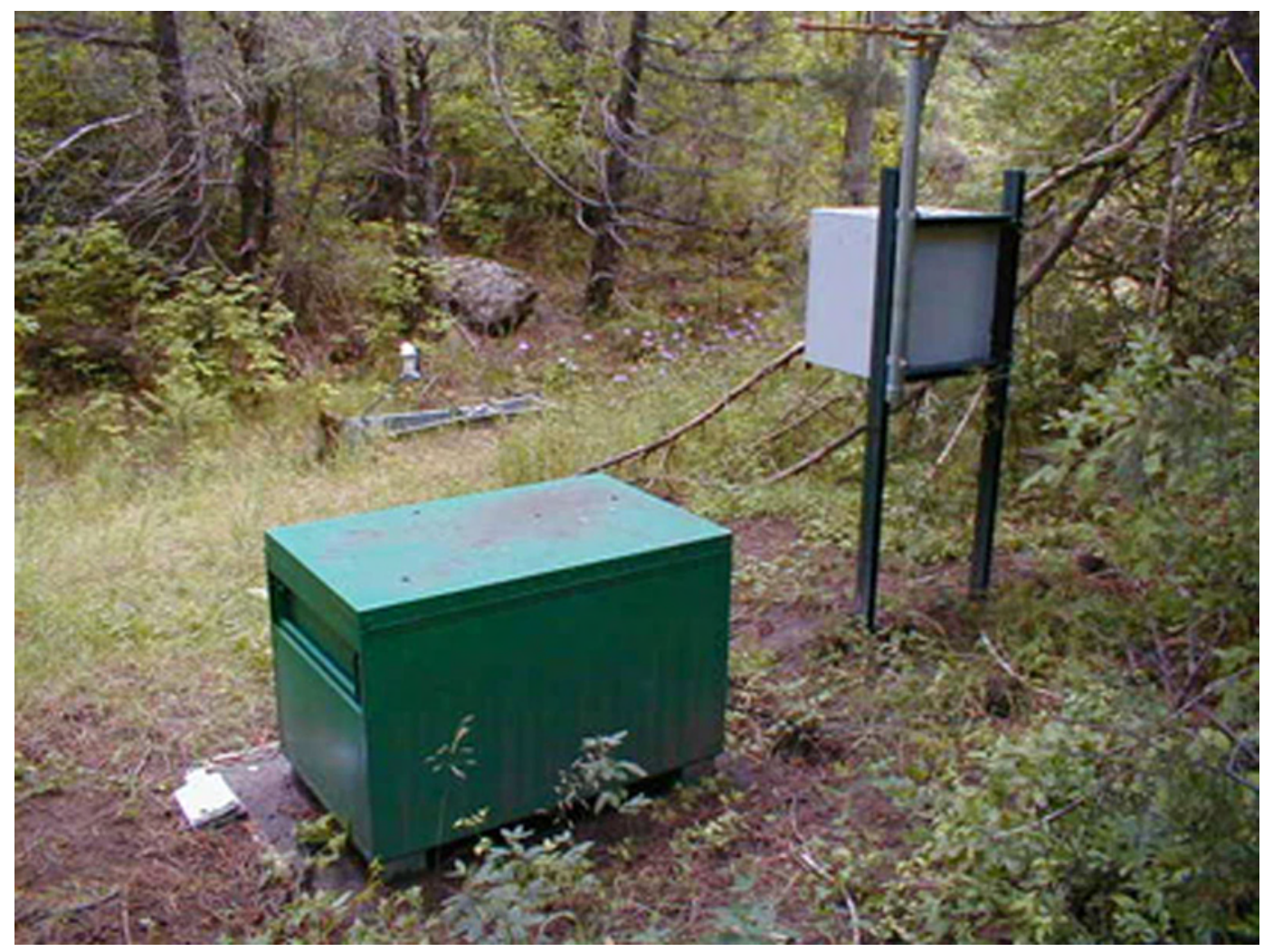




\section{E246 Three Mile above Pajarito \\ Station Analysis \\ 2006 Water Year}

Equipment. Sutron 8210 data logger with cellular phone telemetry with speech modem with a solar panel battery-charging system are housed in a NEMA shelter on right bank. A milltronics sonic probe stage sensor is mounted on top of a 9" Parshall flume. The gaging station is also equipped with an ISCO pump sampler for water quality data collection and is housed in a separate shelter 4' $\times 4^{\prime}$ metal box, which is trigged by the data logger. The staff in the 9" Parshall flume is the reference gage. There is no provision for direct discharge measurements above wading stage.

Field Work. The station was visited fifteen times for the purpose of making a discharge measurement and/or servicing the instrumentation. Field inspections for the gage are listed under site history files on the Hydstra database. Discharge measurements for the gage are listed under site gauging files on the Hydstra database.

Datum Correction. None.

Gage-Height Record. The data logger referenced to the outside staff gave a complete and satisfactory record for the year; except for January 1-9, March 2-30, July 19-27 when data logger lost power and August 25-September 5 when probe was destroyed by flood of August 25, 2006.

Rating. The channel is straight above and below gage. It is confined to the main channel by cut banks on both sides. The bottom is a 10-ft-wide channel prone to some shifting with vegetation on each bank. Low water control is the 9" Parshall flume.

Rating No. 1 was developed based on the computation of 9" Parshall flume and was extended on basis of two critical depth computations and was used directed; except during the spring runoff in 2001 water year when one discharge measurement was made and a variable shift was used. Point of zero flow is 0.00 gage height.

One Critical Depth Computation was made of peak flow this year. Zero shift was used for the entire water year.

Discharge. Discharge was computed by applying Rating No. 1 direct.

Remarks. Records good, except for estimated daily discharges, which are poor. 


\section{E246 Three Mile above Pajarito}

Daily Mean Discharge in Cubic Feet per Second

Water Year October 2005 to September 2006

\begin{tabular}{|c|c|c|c|c|c|c|c|c|c|c|c|c|}
\hline DAY & OCT & NOV & DEC & JAN & FEB & MAR & APR & MAY & JUN & JUL & AUG & SEP \\
\hline 1 & 0 & 0 & 0 & $0^{*}$ & 0 & 0 & 0 & 0 & 0 & 0 & 0 & $0^{*}$ \\
\hline 2 & 0 & 0 & 0 & $0^{*}$ & 0 & $0^{*}$ & 0 & 0 & 0 & 0 & 0 & $0^{*}$ \\
\hline 3 & 0 & 0 & 0 & $0^{*}$ & 0 & $0^{*}$ & 0 & 0 & 0 & 0 & 0 & $0^{*}$ \\
\hline 4 & 0 & 0 & 0 & $0^{*}$ & 0 & $0^{*}$ & 0 & 0 & 0 & 0 & 0 & $0^{*}$ \\
\hline 5 & 0 & 0 & 0 & $0^{*}$ & 0 & $0^{*}$ & 0 & 0 & 0 & 0 & 0 & $0^{*}$ \\
\hline 6 & 0 & 0 & 0 & $0^{*}$ & 0 & $0^{*}$ & 0 & 0 & 0 & 0 & 0 & .03 \\
\hline 7 & 0 & 0 & 0 & $0^{*}$ & 0 & $0^{*}$ & 0 & 0 & 0 & 0 & 0 & $0^{*}$ \\
\hline 8 & 0 & 0 & 0 & $0^{*}$ & 0 & $0^{*}$ & 0 & 0 & 0 & 0 & 0 & $0^{*}$ \\
\hline 9 & 0 & 0 & 0 & $0^{*}$ & 0 & $0^{*}$ & 0 & 0 & 0 & 0 & 0 & $0^{*}$ \\
\hline 10 & 0 & 0 & 0 & 0 & 0 & $0^{*}$ & 0 & 0 & 0 & 0 & 0 & $0^{*}$ \\
\hline 11 & 0 & 0 & 0 & 0 & 0 & $0^{*}$ & 0 & 0 & 0 & 0 & 0 & $0^{*}$ \\
\hline 12 & 0 & 0 & 0 & 0 & 0 & $0^{*}$ & 0 & 0 & 0 & 0 & 0 & $0^{*}$ \\
\hline 13 & 0 & 0 & 0 & 0 & 0 & $0^{*}$ & 0 & 0 & 0 & 0 & 0 & $0^{*}$ \\
\hline 14 & 0 & 0 & 0 & 0 & 0 & $0^{*}$ & 0 & 0 & 0 & 0 & 0 & $0^{*}$ \\
\hline 15 & 0 & 0 & 0 & 0 & 0 & $0^{*}$ & 0 & 0 & 0 & 0 & 0 & $0^{*}$ \\
\hline 16 & 0 & 0 & 0 & 0 & 0 & $0^{*}$ & 0 & 0 & 0 & 0 & 0 & $0^{*}$ \\
\hline 17 & 0 & 0 & 0 & 0 & 0 & $0^{*}$ & 0 & 0 & 0 & 0 & 0 & $0^{*}$ \\
\hline 18 & 0 & 0 & 0 & 0 & 0 & $0^{*}$ & 0 & 0 & 0 & 0 & 0 & $0^{*}$ \\
\hline 19 & 0 & 0 & 0 & 0 & 0 & $0^{*}$ & 0 & 0 & 0 & $0^{*}$ & 0 & $0^{*}$ \\
\hline 20 & 0 & 0 & 0 & 0 & 0 & $0^{*}$ & 0 & 0 & 0 & $0^{*}$ & 0 & $0^{*}$ \\
\hline 21 & 0 & 0 & 0 & 0 & 0 & $0^{*}$ & 0 & 0 & 0 & $0^{*}$ & 0 & $0^{*}$ \\
\hline 22 & 0 & 0 & 0 & 0 & 0 & $0^{*}$ & 0 & 0 & 0 & $0^{*}$ & 0 & $0^{*}$ \\
\hline 23 & 0 & 0 & 0 & 0 & 0 & $0^{*}$ & 0 & 0 & 0 & $0^{*}$ & 0 & $0^{*}$ \\
\hline 24 & 0 & 0 & 0 & 0 & 0 & $0^{*}$ & 0 & 0 & 0 & $0^{*}$ & 0 & $0^{*}$ \\
\hline 25 & 0 & 0 & 0 & 0 & 0 & $0^{*}$ & 0 & 0 & 0 & $0^{*}$ & $9.3^{*}$ & $0^{*}$ \\
\hline 26 & 0 & 0 & 0 & 0 & 0 & $0^{*}$ & 0 & 0 & 0 & $0^{*}$ & $0^{*}$ & $0^{*}$ \\
\hline 27 & 0 & 0 & 0 & 0 & 0 & $0^{*}$ & 0 & 0 & 0 & 0 & $0^{*}$ & $0^{*}$ \\
\hline 28 & 0 & 0 & 0 & 0 & 0 & $0^{*}$ & 0 & 0 & 0 & 0 & $0^{*}$ & $0^{*}$ \\
\hline 29 & 0 & 0 & 0 & 0 & ----- & $0^{*}$ & 0 & 0 & 0 & 0 & $0^{*}$ & $0^{*}$ \\
\hline 30 & 0 & 0 & 0 & 0 & ----- & $0^{*}$ & 0 & 0 & 0 & 0 & $0^{*}$ & $0^{*}$ \\
\hline 31 & 0 & ------ & 0 & 0 & ------ & 0 & ----- & 0 & ------ & 0 & $0^{*}$ & ----.- \\
\hline Total & 0 & 0 & 0 & 0 & 0 & 0 & 0 & 0 & 0 & 0 & 9.3 & 0.03 \\
\hline Mean & 0 & 0 & 0 & 0 & 0 & 0 & 0 & 0 & 0 & 0 & .30 & .001 \\
\hline Max & 0 & 0 & 0 & 0 & 0 & 0 & 0 & 0 & 0 & 0 & 9.3 & .03 \\
\hline Min & 0 & 0 & 0 & 0 & 0 & 0 & 0 & 0 & 0 & 0 & 0 & 0 \\
\hline Acre-Ft & 0 & 0 & 0 & 0 & 0 & 0 & 0 & 0 & 0 & 0 & 18 & .06 \\
\hline Wtr Year & 2006 & Total & 9.33 & Mean & .026 & & Max & & Min & 0 & Acre-Ft & 19 \\
\hline Cal Year & 2005 & Total & 20.87 & Mean & .057 & & Max & 56 & Min & 0 & Acre-Ft & 41 \\
\hline
\end{tabular}

* Estimated 


\section{E2495 MDA G-7}

Location. Lat. 35 49'47", long. $106^{\circ} 14^{\prime} 05^{\prime \prime}$, in Ramon Vigil Grant, Los Alamos County on left bank. North of Pajarito Road, 0.5 mile upstream from SR-4 and 2.0 miles from White Rock.

Drainage Area. $0.01 \mathrm{mi}^{2}$ (5.14 acres).

Period of Record. October 1, 2005, to September 30, 2006

Gage. Data logger and 9" Parshall flume. Records for this site existed before published period but not reliable. Elevation of gage is $6,633 \mathrm{ft}$ above NGVD from GIS 9.1.

Remarks. Water discharge records good.

Extremes for Period of Record. Maximum discharge, $5.7 \mathrm{ft}^{3} / \mathrm{s}$, August 7, 2006, gage height $1.50 \mathrm{ft}$. No flow most of time.

Extremes for Current Year. Maximum discharge, $5.7 \mathrm{ft}^{3} / \mathrm{s}$ at $1605 \mathrm{~h}$, August 7, gage height $1.50 \mathrm{ft}$. No flow most of time.

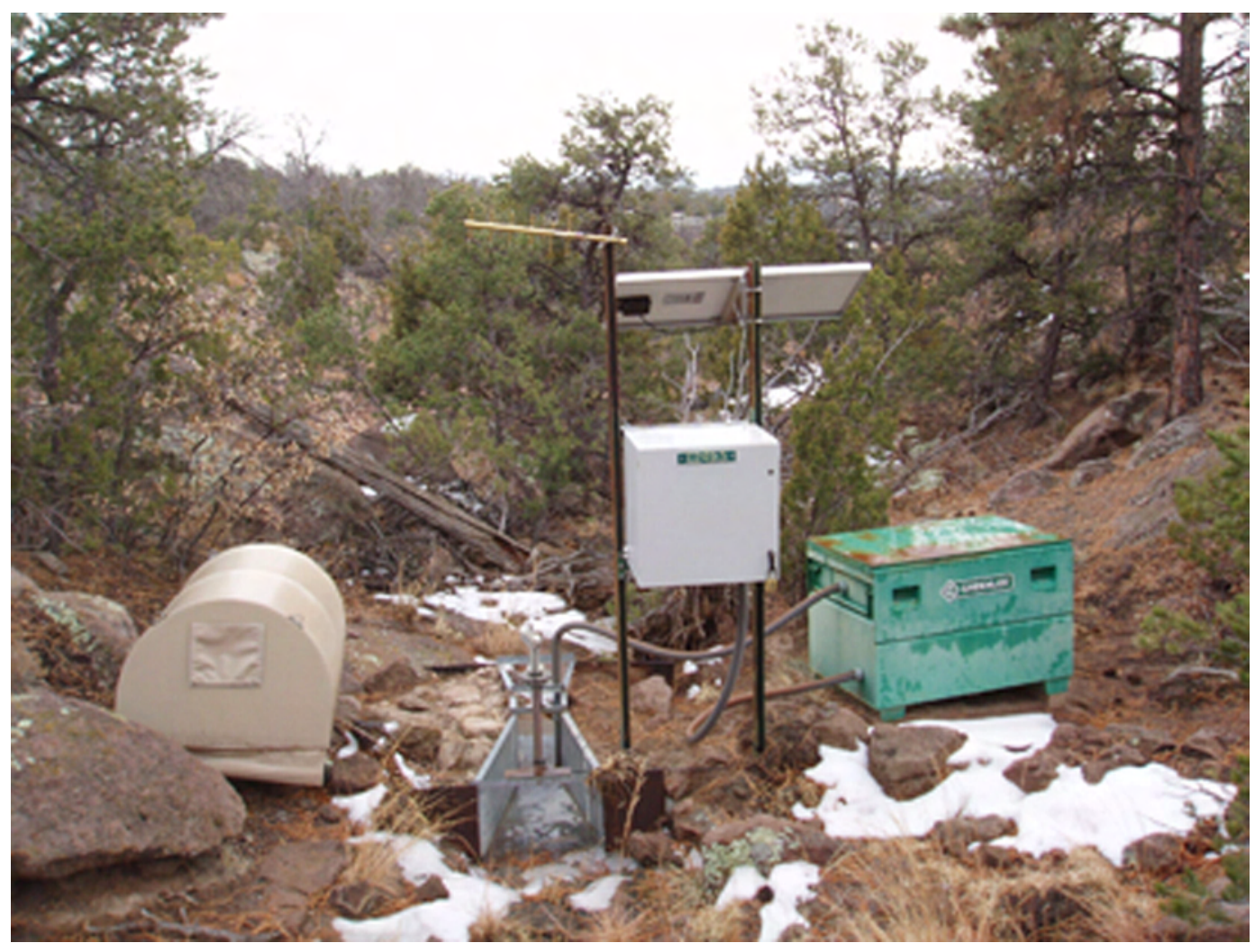




\section{E2495 MDA G-7}

Station Analysis

2006 Water Year

Equipment. Sutron 8210 data logger with a solar panel battery charging system are housed in a NEMA shelter on right bank. A milltronics sonic probe stage sensor is mounted on top a 9" Parshall flume. The gaging station is also equipped with an ISCO pump sampler for water quality data collection and is housed in a separate shelter $4^{\prime} \times 4^{\prime}$ metal box which is trigged by the data logger. The staff in the 9" Parshall flume is the reference gage. There is no provision for direct discharge measurements above wading stage.

Field Work. The station was visited seventeen times for the purpose of making a discharge measurement and/or servicing the instrumentation. Field inspections for the gage are listed under site history files on the Hydstra database. Discharge measurements for the gage are listed under site gauging files on the Hydstra database.

Datum Correction. None.

Gage-Height Record. The data logger referenced to the outside staff gave a complete and satisfactory record for the year; except for August 9 to September 30 when sonic probe was not working.

Rating. The channel is straight above and below gage. It is confined to the main channel by cut banks on both sides. The bottom is 4-feet-wide channel and both banks are very stable. Low water control is the 9" Parshall flume.

Rating No. 1 was developed based on the computation of 9" Parshall flume. Point of zero flow is 0.00 gage height.

During the year, seventeen visits of no flow were made.

Discharge. Discharge was computed by applying Rating No. 1 direct.

Remarks. Records good, except for estimated daily discharges, which are poor. 


\section{E2495 MDA G-7}

Daily Mean Discharge in Cubic Feet per Second

Water Year October 2005 to September 2006

\begin{tabular}{|c|c|c|c|c|c|c|c|c|c|c|c|c|}
\hline DAY & OCT & NOV & DEC & JAN & FEB & MAR & APR & MAY & JUN & JUL & AUG & SEP \\
\hline 1 & 0 & 0 & 0 & 0 & 0 & 0 & 0 & 0 & 0 & .02 & .16 & $0^{*}$ \\
\hline 2 & 0 & 0 & 0 & 0 & 0 & 0 & 0 & 0 & 0 & 0 & 0 & $0^{*}$ \\
\hline 3 & 0 & 0 & 0 & 0 & 0 & 0 & 0 & 0 & 0 & .06 & 0 & $0^{*}$ \\
\hline 4 & 0 & 0 & 0 & 0 & 0 & 0 & 0 & 0 & 0 & 0 & 0 & $0^{*}$ \\
\hline 5 & 0 & 0 & 0 & 0 & 0 & 0 & 0 & 0 & 0 & .15 & .13 & $0^{*}$ \\
\hline 6 & .02 & 0 & 0 & 0 & 0 & 0 & 0 & 0 & 0 & .04 & .10 & $0^{*}$ \\
\hline 7 & 0 & 0 & 0 & 0 & 0 & 0 & 0 & 0 & 0 & 0 & .42 & $0^{*}$ \\
\hline 8 & 0 & 0 & 0 & 0 & 0 & 0 & 0 & 0 & 0 & .05 & .02 & $0^{*}$ \\
\hline 9 & .07 & 0 & 0 & 0 & 0 & 0 & 0 & 0 & 0 & 0 & $0^{*}$ & $0^{*}$ \\
\hline 10 & .04 & 0 & 0 & 0 & 0 & 0 & 0 & 0 & 0 & 0 & $0^{*}$ & $0^{*}$ \\
\hline 11 & 0 & 0 & 0 & 0 & 0 & 0 & 0 & 0 & 0 & 0 & $0^{*}$ & $0^{*}$ \\
\hline 12 & 0 & 0 & 0 & 0 & 0 & 0 & 0 & 0 & 0 & 0 & $0^{*}$ & $0^{*}$ \\
\hline 13 & 0 & 0 & 0 & 0 & 0 & 0 & 0 & 0 & 0 & 0 & $0^{*}$ & $0^{*}$ \\
\hline 14 & 0 & 0 & 0 & 0 & 0 & 0 & 0 & 0 & 0 & 0 & $0^{*}$ & $0^{*}$ \\
\hline 15 & .04 & 0 & 0 & 0 & 0 & 0 & 0 & 0 & 0 & 0 & $0^{*}$ & $0^{*}$ \\
\hline 16 & 0 & 0 & 0 & 0 & 0 & 0 & 0 & 0 & 0 & 0 & $0^{*}$ & $0^{*}$ \\
\hline 17 & 0 & 0 & 0 & 0 & 0 & 0 & 0 & 0 & 0 & 0 & $0^{*}$ & $0^{*}$ \\
\hline 18 & .01 & 0 & 0 & 0 & 0 & 0 & 0 & 0 & 0 & 0 & $0^{*}$ & $0^{*}$ \\
\hline 19 & .02 & 0 & 0 & 0 & 0 & 0 & 0 & 0 & 0 & 0 & $0^{*}$ & $0^{*}$ \\
\hline 20 & 0 & 0 & 0 & 0 & 0 & 0 & 0 & 0 & 0 & 0 & $0^{*}$ & $0^{*}$ \\
\hline 21 & 0 & 0 & 0 & 0 & 0 & 0 & 0 & 0 & 0 & 0 & $0^{*}$ & $0^{*}$ \\
\hline 22 & 0 & 0 & 0 & 0 & 0 & 0 & 0 & 0 & .05 & 0 & $0^{*}$ & $0^{*}$ \\
\hline 23 & 0 & 0 & 0 & 0 & 0 & 0 & 0 & 0 & 0 & 0 & $0^{*}$ & $0^{*}$ \\
\hline 24 & 0 & 0 & 0 & 0 & 0 & 0 & 0 & 0 & 0 & 0 & $0^{*}$ & $0^{*}$ \\
\hline 25 & 0 & 0 & 0 & 0 & 0 & 0 & 0 & 0 & 0 & 0 & $0^{*}$ & $0^{*}$ \\
\hline 26 & 0 & 0 & 0 & 0 & 0 & 0 & 0 & 0 & .01 & 0 & $0^{*}$ & $0^{*}$ \\
\hline 27 & 0 & 0 & 0 & 0 & 0 & 0 & 0 & 0 & 0 & 0 & $0^{*}$ & $0^{*}$ \\
\hline 28 & 0 & 0 & 0 & 0 & 0 & 0 & 0 & 0 & 0 & 0 & $0^{*}$ & $0^{*}$ \\
\hline 29 & 0 & 0 & 0 & 0 & ----- & 0 & 0 & 0 & 0 & 0 & $0^{*}$ & $0^{*}$ \\
\hline 30 & 0 & 0 & 0 & 0 & ------ & 0 & 0 & 0 & 0 & 0 & $0^{*}$ & $0^{*}$ \\
\hline 31 & 0 & ----- & 0 & 0 & ----- & 0 & ----- & 0 & ----- & 0 & $0^{*}$ & ----- \\
\hline Total & 0.20 & 0 & 0 & 0 & 0 & 0 & 0 & 0 & 0.06 & 0.32 & 0.83 & 0 \\
\hline Mean & .007 & 0 & 0 & 0 & 0 & 0 & 0 & 0 & .002 & .010 & .027 & 0 \\
\hline Max & .07 & 0 & 0 & 0 & 0 & 0 & 0 & 0 & .05 & .15 & .42 & 0 \\
\hline Min & 0 & 0 & 0 & 0 & 0 & 0 & 0 & 0 & 0 & 0 & 0 & 0 \\
\hline Acre-Ft & .40 & 0 & 0 & 0 & 0 & 0 & 0 & 0 & .12 & .63 & 1.6 & 0 \\
\hline Wtr Year & 2006 & Total & 1.41 & Mean & .004 & & hax & .42 & Min & 0 & Acre-Ft & 2.8 \\
\hline Cal Year & 2005 & Total & 1.56 & Mean & .004 & & Иax & .20 & Min & 0 & Acre-Ft & 3.1 \\
\hline
\end{tabular}




\section{E250 Pajarito above SR 4}

Location. Lat. 3549'26", long. 106 13'40.", in Ramon Vigil Grant, Los Alamos County on left bank, $400 \mathrm{ft}$ southeast of Pajarito Road, 0.40 mile upstream from SR 4, and 1.4 miles from White Rock, New Mexico.

Drainage Area. $10.6 \mathrm{mi}^{2}$.

Period of Record. November 1993 to September 30, 2006.

Revised Record. Drainage Area (this report).

Gage. Data logger with cellular telemetry and concrete control. Elevation of gage is 6,528 $\mathrm{ft}$ above NGVD from GIS 9.1.

Remarks. Water discharge records good.

Average Discharge. $12 \mathrm{yr}, 0.06 \mathrm{ft}^{3} / \mathrm{s}, 43$ acre- $\mathrm{ft} / \mathrm{yr}$.

Extremes for Period of Record. Maximum discharge $206 \mathrm{ft}^{3} / \mathrm{s}$, August 25, 2006, gage height $4.62 \mathrm{ft}$. , (from peak flow computations). No flow most of time.

Extremes for Current Water Year. Maximum discharge $206 \mathrm{ft}^{3} / \mathrm{s}$ at $1710 \mathrm{~h}$, August 25, gage height $4.62 \mathrm{ft}$, (from peak flow computations). No flow most of time.

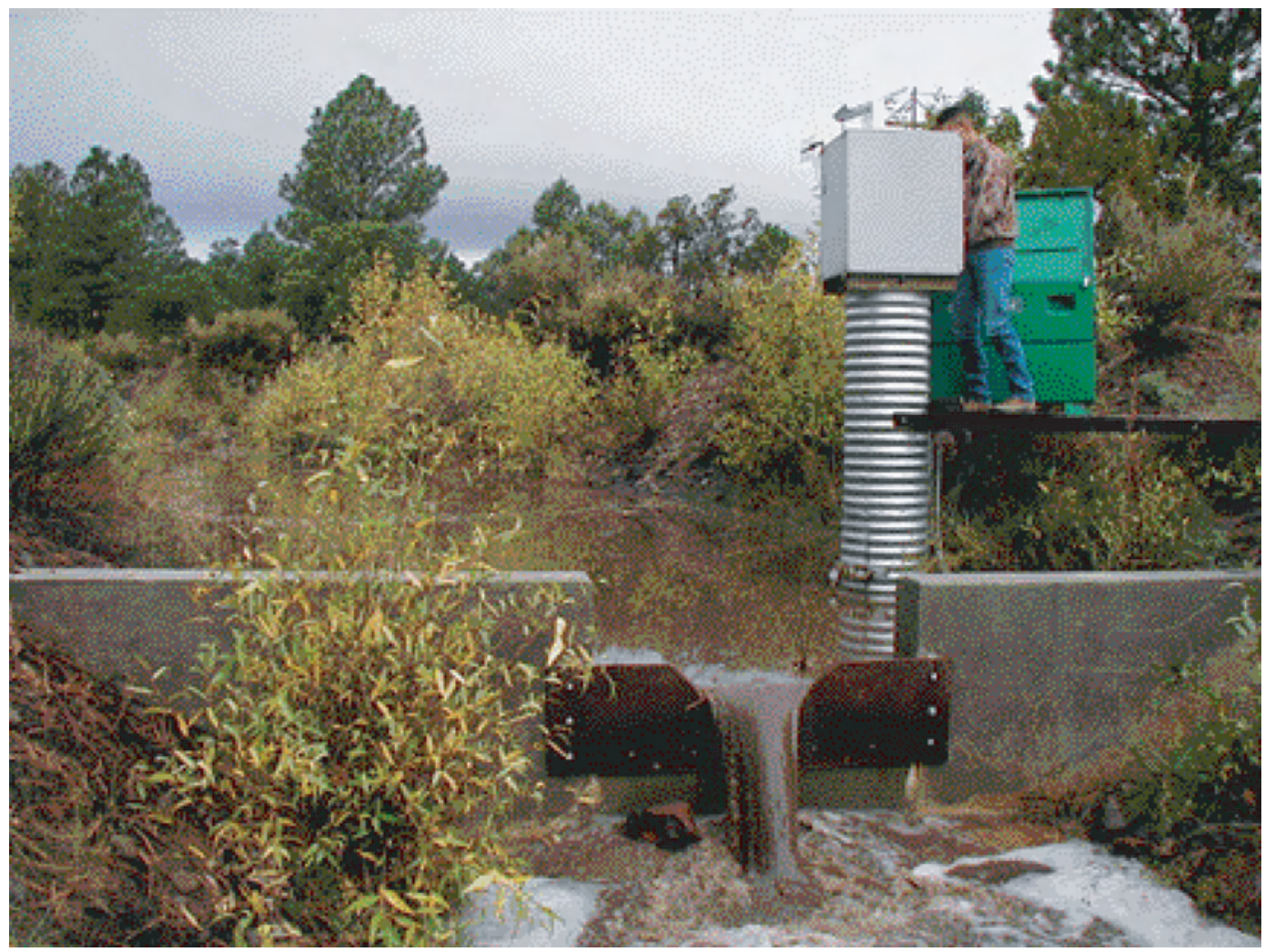




\section{E250 Pajarito above SR 4 \\ Station Analysis \\ 2006 Water Year}

Equipment. Sutron 8210 data logger with cellular telemetry in NEMA shelter on 18" CMP well on right bank. Outside staff is reference gage. Auxiliary shelters houses battery and ISCO automatic samplers. Access to this station is controlled by DX access control personnel because of explosive testing in parts of the area. No provision for discharge measurements above wading stages.

Field Work. The station was visited eight times for the purpose of making a discharge measurement and/or servicing the instrumentation. Field inspections for the gage are listed under site history files on the Hydstra database. Discharge measurements for the gage are listed under site gauging files on the Hydstra database.

Datum Correction. None. Last levels run November 19, 1993, found gage within acceptable limits.

Gage-Height Record. Gage height record was complete for year.

Rating. The channel is straight for 50 feet above and 100 feet below gage. Bed material is gravel. The control is concrete with 90-degree weir plate.

Rating No. 1 was developed from 90-degree weir formula and broad crested weir computation above notch.

One critical depth computation of peak flow (No. 11) and eight visits were made this water year. Rating No. 1 was continued in use and is considered good.

The critical depth computation was done on peak of August 25 to define rating at this peak of record.

Discharge. Computed from Rating No. 1 using mean daily gage height three "V" diagram with $0.14 \mathrm{ft}$. shift was used for all low flow periods. This shift value was defined by the measurements.

Remarks. Records good. 
E250 Pajarito above SR 4

Daily Mean Discharge in Cubic Feet per Second

Water Year October 2005 to September 2006

\begin{tabular}{|c|c|c|c|c|c|c|c|c|c|c|c|c|}
\hline DAY & OCT & NOV & DEC & JAN & FEB & MAR & APR & MAY & JUN & JUL & AUG & SEP \\
\hline 1 & 0 & 0 & 0 & 0 & 0 & 0 & 0 & 0 & 0 & 0 & 0 & 0 \\
\hline 2 & 0 & 0 & 0 & 0 & 0 & 0 & 0 & 0 & 0 & 0 & 0 & 0 \\
\hline 3 & 0 & 0 & 0 & 0 & 0 & 0 & 0 & 0 & 0 & 0 & 0 & 0 \\
\hline 4 & 0 & 0 & 0 & 0 & 0 & 0 & 0 & 0 & 0 & 0 & 0 & 0 \\
\hline 5 & 0 & 0 & 0 & 0 & 0 & 0 & 0 & 0 & 0 & 0 & 0 & 0 \\
\hline 6 & 0 & 0 & 0 & 0 & 0 & 0 & 0 & 0 & 0 & 0 & 0 & 0 \\
\hline 7 & 0 & 0 & 0 & 0 & 0 & 0 & 0 & 0 & 0 & 0 & 0 & 0 \\
\hline 8 & 0 & 0 & 0 & 0 & 0 & 0 & 0 & 0 & 0 & 0 & 0 & 0 \\
\hline 9 & 0 & 0 & 0 & 0 & 0 & 0 & 0 & 0 & 0 & 0 & 0 & 0 \\
\hline 10 & 0 & 0 & 0 & 0 & 0 & 0 & 0 & 0 & 0 & 0 & 0 & 0 \\
\hline 11 & 0 & 0 & 0 & 0 & 0 & 0 & 0 & 0 & 0 & 0 & 0 & 0 \\
\hline 12 & 0 & 0 & 0 & 0 & 0 & 0 & 0 & 0 & 0 & 0 & 0 & 0 \\
\hline 13 & 0 & 0 & 0 & 0 & 0 & 0 & 0 & 0 & 0 & 0 & 0 & 0 \\
\hline 14 & 0 & 0 & 0 & 0 & 0 & 0 & 0 & 0 & 0 & 0 & 0 & 0 \\
\hline 15 & 0 & 0 & 0 & 0 & 0 & 0 & 0 & 0 & 0 & 0 & 0 & 0 \\
\hline 16 & 0 & 0 & 0 & 0 & 0 & 0 & 0 & 0 & 0 & 0 & 0 & 0 \\
\hline 17 & 0 & 0 & 0 & 0 & 0 & 0 & 0 & 0 & 0 & 0 & 0 & 0 \\
\hline 18 & 0 & 0 & 0 & 0 & 0 & 0 & 0 & 0 & 0 & 0 & 0 & 0 \\
\hline 19 & 0 & 0 & 0 & 0 & 0 & 0 & 0 & 0 & 0 & 0 & 0 & 0 \\
\hline 20 & 0 & 0 & 0 & 0 & 0 & 0 & 0 & 0 & 0 & 0 & 0 & 0 \\
\hline 21 & 0 & 0 & 0 & 0 & 0 & 0 & 0 & 0 & 0 & 0 & 0 & 0 \\
\hline 22 & 0 & 0 & 0 & 0 & 0 & 0 & 0 & 0 & 0 & 0 & 0 & 0 \\
\hline 23 & 0 & 0 & 0 & 0 & 0 & 0 & 0 & 0 & 0 & 0 & 0 & 0 \\
\hline 24 & 0 & 0 & 0 & 0 & 0 & 0 & 0 & 0 & 0 & 0 & 0 & 0 \\
\hline 25 & 0 & 0 & 0 & 0 & 0 & 0 & 0 & 0 & 0 & 0 & 14 & 0 \\
\hline 26 & 0 & .06 & 0 & 0 & 0 & 0 & 0 & 0 & 0 & 0 & 1.4 & 0 \\
\hline 27 & 0 & .04 & 0 & 0 & 0 & 0 & 0 & 0 & 0 & 0 & 0 & 0 \\
\hline 28 & 0 & .02 & 0 & 0 & 0 & 0 & 0 & 0 & 0 & 0 & 0 & 0 \\
\hline 29 & 0 & 0 & 0 & 0 & ------ & 0 & 0 & 0 & 0 & 0 & 0 & 0 \\
\hline 30 & 0 & 0 & 0 & 0 & ------ & 0 & 0 & 0 & 0 & 0 & 0 & 0 \\
\hline 31 & 0 & ---- & 0 & 0 & ----- & 0 & ----- & 0 & ----- & 0 & 0 & ---- \\
\hline Total & 0 & 0.12 & 0 & 0 & 0 & 0 & 0 & 0 & 0 & 0 & 15.4 & 0 \\
\hline Mean & 0 & .004 & 0 & 0 & 0 & 0 & 0 & 0 & 0 & 0 & .50 & 0 \\
\hline Max & 0 & .06 & 0 & 0 & 0 & 0 & 0 & 0 & 0 & 0 & 14 & 0 \\
\hline Min & 0 & 0 & 0 & 0 & 0 & 0 & 0 & 0 & 0 & 0 & 0 & 0 \\
\hline Acre-Ft & 0 & .24 & 0 & 0 & 0 & 0 & 0 & 0 & 0 & 0 & 31 & 0 \\
\hline Wtr Year & 2006 & Total & 15.52 & Mean & .0 & & $\operatorname{Max}$ & & Min & 0 & Acre-Ft & 31 \\
\hline Cal Year & 2005 & Total & 128.66 & Mean & .35 & & Max & 3 & Min & 0 & Acre-Ft & 255 \\
\hline
\end{tabular}




\section{E252 Water above SR 501}

Location. Lat. 3550'18", long. 106 21'42", T. 19 N, R. 5 E, Los Alamos County in Santa Fe National Forest, 0.3 mile upstream from SR 501, and 0.4 mile northwest of junction of SR 501 and SR 4.

Drainage Area. $3.25 \mathrm{mi}^{2}$.

Period of Record. October 1994 to September 2000; October 2000 to June 2000 (destroyed by flood); April 2001 to September 2006.

Revised Record. Drainage Area (this report).

Gage. Data logger with cellular telemetry. Elevation of gage is 7,553 ft above NGVD from GIS 9.1. New location $30 \mathrm{ft}$ upstream at same datum.

Remarks. Records poor.

Average Discharge. $12 \mathrm{yr}, 0.09 \mathrm{ft}^{3} / \mathrm{s}, 65$ acre- $\mathrm{ft} / \mathrm{yr}$.

Extremes for Period of Record. Maximum discharge $840 \mathrm{ft}^{3} / \mathrm{s}$ on June 28, 2000, from peak flow computation, gage height $7.91 \mathrm{ft}$. No flow at times.

Extremes for Current Water Year. Maximum discharge $2.5 \mathrm{ft}^{3} / \mathrm{s}$, August 14, gage height $2.69 \mathrm{ft}$. Minimum discharge $0.01 \mathrm{ft}^{3} / \mathrm{s}$ on many days.

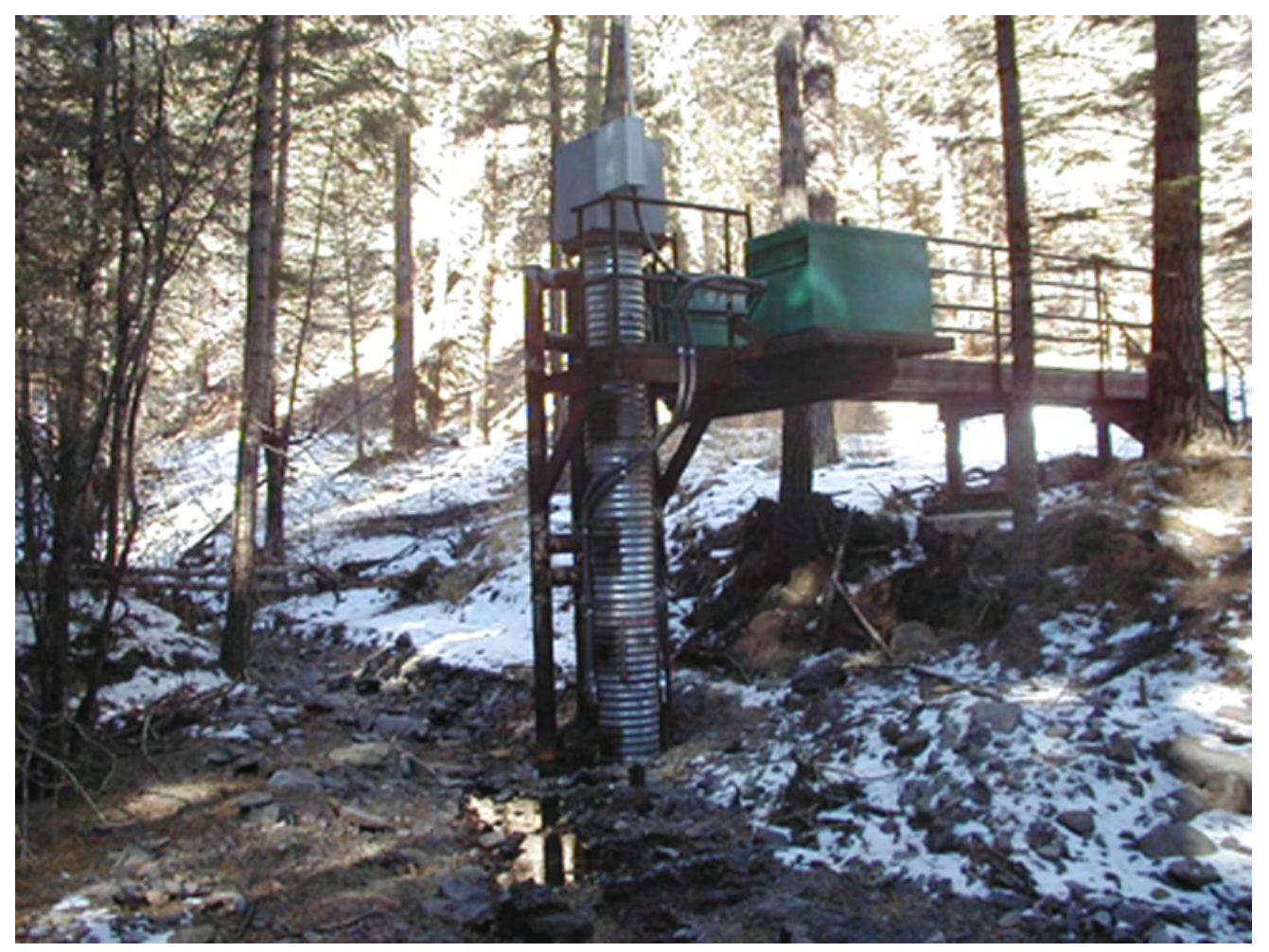




\section{E252 Water above SR 501 \\ Station Analysis \\ 2006 Water Year}

Equipment. Sutron 8210 data logger with cellular telemetry housed in NEMA shelter on top of 24" CMP well. Two ISCO-brand automatic samplers are housed in separate shelters and are stage-triggered by the data logger. A tipping bucket rain gage is also available. There is no low water control and no provision for direct discharge measurements above wading stages.

Field Work. The station was visited fifteen times for the purpose of making a discharge measurement and/or servicing the instrumentation. Field inspections for the gage are listed under site history files on the Hydstra database. Discharge measurements for the gage are listed under site gauging files on the Hydstra database.

Datum Correction. None. Levels were run when gage was established April 16, 2001. New gage is at same datum as old and is about 20 feet upstream of old stilling well.

Gage-Height Record. The data logger referenced to the inside staff and reference point gave a complete and satisfactory record except June 15-23 and July 31 to August 8 when data logger malfunctioned.

Rating. The channel at the gage is 30 feet wide and straight for about 40 feet upstream and bends to the left and 100 feet straight downstream from the gage. The streambed through this reach is primary sand, gravel and cobbles. Low flow control is rock riffle 5 feet below gage. The channel has been scoured and filled significantly by high flows resulting from the Cerro Grande fire.

Rating No. 3 should be considered good except for the extreme lower end (less than $0.5 \mathrm{cfs}$ ) which will continue to change back and forth in response to high flows. Steep slopes in the gage reach, actually this whole region causes considerable movement of material, either scours or fills. Low water records at this site will continue to be a problem until increased runoff from the burned areas returns to something close to prefire conditions.

Nine discharge measurements (No. 38-46) and six inspections were made during the period. All measurements listed indicated shifts ranging from +.12 to +.21 . The shifts were applied using several different variable stage shifts prorated over time.

Discharge. Rating No. 3 was used for the entire water year.

Remarks. Records good. 


\section{E252 Water above SR 501}

Daily Mean Discharge in Cubic Feet per Second

Water Year October 2005 to September 2006

\begin{tabular}{|c|c|c|c|c|c|c|c|c|c|c|c|c|}
\hline DAY & OCT & NOV & DEC & JAN & FEB & MAR & APR & MAY & JUN & JUL & AUG & SEP \\
\hline 1 & .11 & .13 & .07 & .03 & .01 & .01 & .02 & .01 & .01 & .01 & $.01^{*}$ & .26 \\
\hline 2 & .21 & .12 & .07 & .03 & .01 & .01 & .02 & .01 & .01 & .01 & $.01^{*}$ & .25 \\
\hline 3 & .23 & .12 & .07 & .03 & .01 & .01 & .02 & .01 & .01 & .01 & $.01^{*}$ & .23 \\
\hline 4 & .23 & .12 & .07 & .03 & .01 & .01 & .02 & .01 & .01 & .02 & $.01^{*}$ & .22 \\
\hline 5 & .21 & .12 & .07 & .03 & .01 & .01 & .03 & .01 & .01 & .01 & $.01^{*}$ & .20 \\
\hline 6 & .18 & .13 & .06 & .03 & .01 & .01 & .02 & .01 & .01 & .01 & $.01^{*}$ & .19 \\
\hline 7 & .18 & .12 & .06 & .03 & .01 & .01 & .03 & .01 & .01 & .01 & $.01^{*}$ & .19 \\
\hline 8 & .18 & .10 & .06 & .03 & .01 & .01 & .02 & .01 & .02 & .01 & .01 & .19 \\
\hline 9 & .16 & .10 & .06 & .03 & .01 & .01 & .03 & .01 & .02 & .01 & .01 & .17 \\
\hline 10 & .15 & .09 & .06 & .03 & .01 & .01 & .03 & .01 & .02 & .01 & .01 & .18 \\
\hline 11 & .15 & .09 & .06 & .03 & .02 & .01 & .03 & .01 & .02 & .01 & .01 & .16 \\
\hline 12 & .16 & .09 & .06 & .03 & .02 & .01 & .03 & .01 & .02 & .01 & .01 & .16 \\
\hline 13 & .16 & .09 & .06 & .02 & .02 & .01 & .03 & .01 & .02 & .01 & .01 & .16 \\
\hline 14 & .14 & .09 & .06 & .02 & .02 & .01 & .03 & .01 & .01 & .01 & .15 & .16 \\
\hline 15 & .13 & .09 & .06 & .02 & .02 & .01 & .03 & .01 & $.01^{*}$ & .01 & .13 & .15 \\
\hline 16 & .13 & .09 & .06 & .02 & .02 & .01 & .03 & .01 & $.01^{*}$ & .01 & .18 & .14 \\
\hline 17 & .14 & .08 & .05 & .02 & .02 & .01 & .02 & .01 & $.01^{*}$ & .01 & .21 & .14 \\
\hline 18 & .10 & .08 & .05 & .02 & .02 & .02 & .01 & .01 & $.01^{*}$ & .01 & .20 & .14 \\
\hline 19 & .06 & .08 & .05 & .02 & .02 & .02 & .01 & .01 & $.01^{*}$ & .01 & .18 & .12 \\
\hline 20 & .06 & .08 & .05 & .02 & .02 & .02 & .01 & .01 & $.01^{*}$ & .01 & .19 & .13 \\
\hline 21 & .07 & .08 & .05 & .01 & .02 & .02 & .01 & .01 & $.01^{*}$ & .01 & .18 & .12 \\
\hline 22 & .08 & .08 & .05 & .01 & .02 & .01 & .01 & .01 & $.02^{*}$ & .01 & .18 & .11 \\
\hline 23 & .09 & .08 & .05 & .01 & .02 & .01 & .01 & .01 & $.02^{*}$ & .01 & .18 & .11 \\
\hline 24 & .10 & .08 & .04 & .01 & .02 & .01 & .01 & .01 & .02 & .01 & .18 & .11 \\
\hline 25 & .11 & .08 & .04 & .01 & .02 & .02 & .01 & .01 & .01 & .01 & .43 & .09 \\
\hline 26 & .15 & .08 & .04 & .01 & .02 & .02 & .01 & .01 & .01 & .01 & .56 & .09 \\
\hline 27 & .17 & .07 & .04 & .01 & .02 & .02 & .01 & .01 & .01 & .01 & .35 & .09 \\
\hline 28 & .17 & .07 & .04 & .01 & .02 & .02 & .01 & .01 & .01 & .01 & .29 & .08 \\
\hline 29 & .14 & .07 & .04 & .01 & ------ & .02 & .01 & .01 & .01 & .01 & .29 & .08 \\
\hline 30 & .13 & .07 & .03 & .01 & ----- & .02 & .01 & .01 & .01 & .01 & .29 & .08 \\
\hline 31 & .13 & ------ & .03 & .01 & ------ & .02 & ----- & .01 & ------ & $.01^{*}$ & .26 & ---- \\
\hline Total & 4.41 & 2.77 & 1.66 & 0.63 & 0.46 & 0.42 & 0.57 & 0.31 & 0.39 & 0.32 & 4.56 & 4.50 \\
\hline Mean & .14 & .092 & .054 & .020 & .016 & .014 & .019 & .010 & .013 & .010 & .15 & .15 \\
\hline Max & .23 & .13 & .07 & .03 & .02 & .02 & .03 & .01 & .02 & .02 & .56 & .26 \\
\hline Min & .06 & .07 & .03 & .01 & .01 & .01 & .01 & .01 & .01 & .01 & .01 & .08 \\
\hline Acre-Ft & 8.7 & 5.5 & 3.3 & 1.2 & .91 & .83 & 1.1 & .61 & .77 & .63 & 9.0 & 8.9 \\
\hline Wtr Year & 2006 & Total & 21.00 & Mean & .058 & & Max & .56 & Min & .01 & Acre-Ft & 42 \\
\hline Cal Year & 2005 & Total & 129.42 & Mean & .36 & & Max & 1.8 & Min & 0 & Acre-Ft & 257 \\
\hline
\end{tabular}

* Estimated 


\section{E2528 S-Site Canyon above Water}

Location. Lat. 3549'51", long. 106 $18^{\prime} 27^{\prime \prime}$, in Ramon Vigil Grant, Los Alamos County, on left bank, $50 \mathrm{ft}$ above confluence with Water Canyon, 0.4 mile upstream of E262, 2.0 miles upstream from E2625, and 4.6 miles upstream from SR 4.

Drainage Area. $0.76 \mathrm{mi}^{2}$.

Period of Record. April 1999 to September 30, 2006.

Revised Record. Drainage Area (this report).

Gage. Data logger with cellular telemetry and $90^{\circ}$ sharp-crested weir. Elevation of gage is 6,840 ft above NGVD from GIS 9.1.

Remarks. Water discharge records good.

Extremes for Period of Record. Maximum discharge $162 \mathrm{ft}^{3} / \mathrm{s}$ August 20, 2004, gage height $4.03 \mathrm{ft}$. No flow most of time.

Average Discharge. $7 \mathrm{yr}, 0.002 \mathrm{ft}^{3} / \mathrm{s} .1 .4$ acre-ft/yr.

Extremes for Current Year. Maximum discharge $77 \mathrm{ft}^{3} / \mathrm{s}$ at $1300 \mathrm{~h}$, August 25, gage height $3.71 \mathrm{ft}$ (from flood mark). No flow most of time.

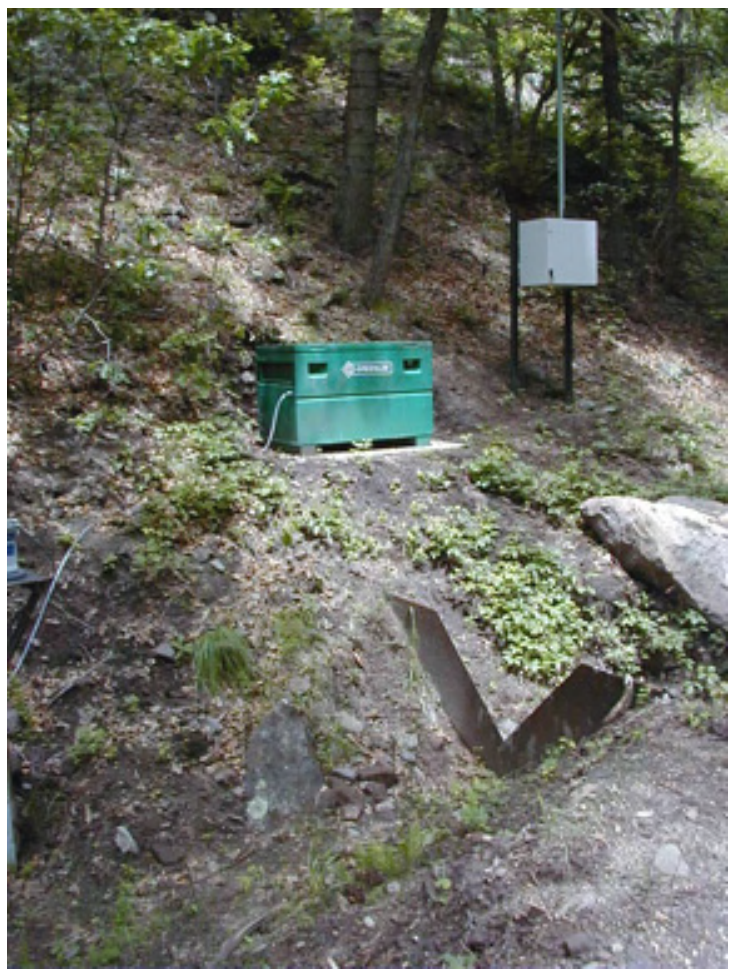




\section{E2528 S-Site Canyon above Water \\ Station Analysis \\ 2006 Water Year}

Equipment. Sutron 8210 data logger (5-min. interval) with cellular phone and speech modem housed in a NEMA shelter on left bank is supplied gage height from milltronics Sonic Probe. ISCO brand automatic sampler is stage-triggered by the data logger. No provision for direct measurement of flows above wading stage.

Field Work. The station was visited thirteen times for the purpose of making a discharge measurement and/or servicing the instrumentation. Field inspections for the gage are listed under site history files on the Hydstra database. Discharge measurements for the gage are listed under site gauging files on the Hydstra database.

Datum Correction. None.

Gage-Height Record. All these losses are result of power failure from "trace regulator" cutoffs to lack of solar gain in the winter outages. Data that were lost during December and January were no flow according to field inspection.

Rating. Control is 90 degree weir with $2 \mathrm{ft}$. deep notch. Canyon is very steep directly above station but does flatten out enough to allow weir to be effective.

Rating No. 1 was developed using weir formula $Q=2.49$ h 2.48 and one critical dept computation made in 2004 water year. Rating No. 1 is fair and was used for the entire period of this analysis. Large shifts were applied to the low end (PZF) because of filling in the pool. These were most likely to change over time when fill conditions occurred.

Thirteen inspections of no flow were made this water year.

Discharge. Discharge was computed from Rating No. 1 with "V" diagrams adjusting the PZF. Period of no gage height was estimated based on adjoining stations E2525 and E262, weather records, and inspections.

Remarks. Records good. 


\section{E2528 S-Site Canyon above Water}

Daily Mean Discharge in Cubic Feet per Second

Water Year October 2005 to September 2006

\begin{tabular}{|c|c|c|c|c|c|c|c|c|c|c|c|c|}
\hline DAY & OCT & NOV & DEC & JAN & FEB & MAR & APR & MAY & JUN & JUL & AUG & SEP \\
\hline 1 & 0 & 0 & $0^{*}$ & $0^{*}$ & 0 & 0 & 0 & 0 & 0 & 0 & 0 & 0 \\
\hline 2 & 0 & 0 & $0^{*}$ & $0^{*}$ & 0 & 0 & 0 & 0 & 0 & 0 & 0 & 0 \\
\hline 3 & 0 & 0 & $0^{*}$ & $0^{*}$ & 0 & 0 & 0 & 0 & 0 & 0 & 0 & 0 \\
\hline 4 & 0 & 0 & $0^{*}$ & $0^{*}$ & 0 & 0 & 0 & 0 & 0 & 0 & 0 & 0 \\
\hline 5 & 0 & 0 & $0^{*}$ & $0^{*}$ & 0 & 0 & 0 & 0 & 0 & 0 & 0 & 0 \\
\hline 6 & 0 & 0 & $0^{*}$ & $0^{*}$ & 0 & 0 & 0 & 0 & 0 & 0 & 0 & 0 \\
\hline 7 & 0 & 0 & $0^{*}$ & $0^{*}$ & 0 & 0 & 0 & 0 & 0 & 0 & 0 & 0 \\
\hline 8 & 0 & 0 & $0^{*}$ & $0^{*}$ & 0 & 0 & 0 & 0 & 0 & 0 & 0 & 0 \\
\hline 9 & 0 & 0 & $0^{*}$ & $0^{*}$ & 0 & 0 & 0 & 0 & 0 & 0 & 0 & 0 \\
\hline 10 & 0 & 0 & $0^{*}$ & $0^{*}$ & 0 & 0 & 0 & 0 & 0 & 0 & 0 & 0 \\
\hline 11 & 0 & 0 & $0^{*}$ & $0^{*}$ & 0 & 0 & 0 & 0 & 0 & 0 & 0 & .25 \\
\hline 12 & 0 & 0 & $0^{*}$ & $0^{*}$ & 0 & 0 & 0 & 0 & 0 & 0 & 0 & 0 \\
\hline 13 & 0 & 0 & $0^{*}$ & $0^{*}$ & 0 & 0 & 0 & 0 & 0 & 0 & 0 & 0 \\
\hline 14 & 0 & 0 & $0^{*}$ & $0^{*}$ & 0 & 0 & 0 & 0 & 0 & 0 & 0 & 0 \\
\hline 15 & 0 & 0 & $0^{*}$ & $0^{*}$ & 0 & 0 & 0 & 0 & 0 & 0 & 0 & 0 \\
\hline 16 & 0 & 0 & $0^{*}$ & $0^{*}$ & 0 & 0 & 0 & 0 & 0 & 0 & 0 & 0 \\
\hline 17 & 0 & 0 & $0^{*}$ & $0^{*}$ & 0 & 0 & 0 & 0 & 0 & 0 & 0 & 0 \\
\hline 18 & 0 & 0 & $0^{*}$ & $0^{*}$ & 0 & 0 & 0 & 0 & 0 & 0 & 0 & 0 \\
\hline 19 & 0 & 0 & $0^{*}$ & $0^{*}$ & 0 & 0 & 0 & 0 & 0 & 0 & 0 & 0 \\
\hline 20 & 0 & 0 & $0^{*}$ & $0^{*}$ & 0 & 0 & 0 & 0 & 0 & 0 & .05 & 0 \\
\hline 21 & 0 & 0 & $0^{*}$ & $0^{*}$ & 0 & 0 & 0 & 0 & 0 & 0 & .08 & 0 \\
\hline 22 & 0 & 0 & $0^{*}$ & $0^{*}$ & 0 & 0 & 0 & 0 & 0 & 0 & 0 & 0 \\
\hline 23 & 0 & 0 & $0^{*}$ & $0^{*}$ & 0 & 0 & 0 & 0 & 0 & 0 & 0 & 0 \\
\hline 24 & 0 & 0 & $0^{*}$ & $0^{*}$ & 0 & 0 & 0 & 0 & 0 & 0 & 0 & 0 \\
\hline 25 & 0 & 0 & $0^{*}$ & $0^{*}$ & 0 & 0 & 0 & 0 & 0 & 0 & 1.8 & 0 \\
\hline 26 & 0 & 0 & $0^{*}$ & $0^{*}$ & 0 & 0 & 0 & 0 & 0 & 0 & .04 & 0 \\
\hline 27 & 0 & 0 & $0^{*}$ & $0^{*}$ & 0 & 0 & 0 & 0 & 0 & 0 & 0 & 0 \\
\hline 28 & 0 & 0 & $0^{*}$ & $0^{*}$ & 0 & 0 & 0 & 0 & 0 & 0 & 0 & 0 \\
\hline 29 & 0 & 0 & $0^{*}$ & $0^{*}$ & ------- & 0 & 0 & 0 & .81 & 0 & 0 & 0 \\
\hline 30 & 0 & 0 & $0^{*}$ & $0^{*}$ & ------ & 0 & 0 & 0 & .02 & 0 & 0 & 0 \\
\hline 31 & 0 & ------- & $0^{*}$ & $0^{*}$ & ------ & 0 & & 0 & ------ & 0 & 0 & ----- \\
\hline Total & 0 & 0 & 0 & 0 & 0 & 0 & 0 & 0 & 0.83 & 0 & 1.97 & 0.25 \\
\hline Mean & 0 & 0 & 0 & 0 & 0 & 0 & 0 & 0 & .028 & 0 & .064 & .008 \\
\hline $\operatorname{Max}$ & 0 & 0 & 0 & 0 & 0 & 0 & 0 & 0 & .81 & 0 & 1.8 & .25 \\
\hline Min & 0 & 0 & 0 & 0 & 0 & 0 & 0 & 0 & 0 & 0 & 0 & 0 \\
\hline Acre-Ft & 0 & 0 & 0 & 0 & 0 & 0 & 0 & 0 & 1.6 & 0 & 3.9 & .50 \\
\hline Wtr Year & 2006 & Total & 3.05 & Mean & .008 & & $\operatorname{Max}$ & .8 & Min & 0 & Acre-Ft & 6.0 \\
\hline Cal Year & 2005 & Total & 0.40 & Mean & .001 & & Max & .27 & Min & 0 & Acre-Ft & .79 \\
\hline
\end{tabular}




\section{E253 Cañon de Valle above SR 501}

Location. Lat. 35 51'6", long. 106²1'17" NE 1/4 sec. 25, T. 19 N, R. 5 E, Los Alamos County in Santa Fe National Forest, on left bank 0.25 mile upstream from SR 501, 4.7 miles above mouth, and 1.5 miles north of junction of SR 501 and SR 4.

Drainage Area. $2.27 \mathrm{mi}^{2}$.

Period of Record. October 1994 to June 2000 (when gage was destroyed); January 31, 2001, to September 30, 2006.

Gage. Data logger with cellular telemetry and $120^{\circ}$ weir plate. Elevation of gage is $7,701 \mathrm{ft}$ above NGVD from GIS 9.1.

Remarks. Records good.

Average Discharge. $12 \mathrm{yr}, 0.03 \mathrm{ft}^{3} / \mathrm{s}, 22$ acre- $\mathrm{ft} / \mathrm{yr}$.

Extremes for Period of Record. Maximum discharge $740 \mathrm{ft}^{3} / \mathrm{s}$, June 28, 2000, from peak flow computation, gage height $8.42 \mathrm{ft}$. No flow most of time.

Extremes for Current Water Year. Maximum discharge $0.13 \mathrm{ft}^{3} / \mathrm{s}, 1225 \mathrm{~h}$, August 8, gage height $1.21 \mathrm{ft}$. No flow most of time.

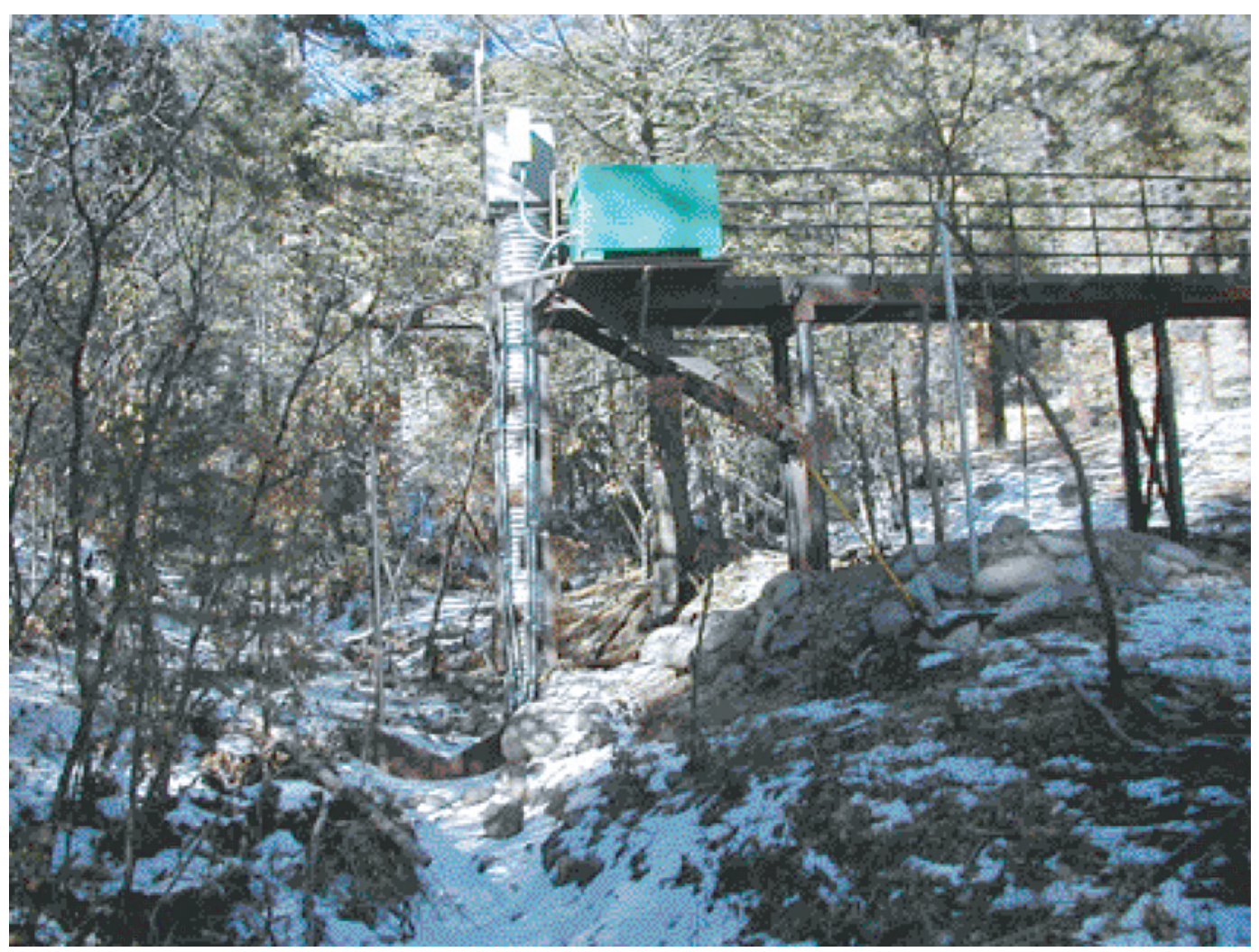




\section{E253 Cañon de Valle above SR 501 \\ Station Analysis \\ 2006 Water Year}

Equipment. Sutron 8210 data logger (5-min. interval) with Sutron shaft encorder float system and cellular phone with speech modem housed in a NEMA shelter on top of 24" CMP well 16 feet long attached to a 60-ft-metal walkway on left bank. The equipment is powered by a solar panel charging system. Auxiliary shelter houses one ISCO sampler, which is triggered by stage through the Sutron 8210. The outside staff is used for reference. No provision for measurement above wading stage.

Field Work. The station was visited ten times for the purpose of making a discharge measurement and/or servicing the instrumentation. Field inspections for the gage are listed under site history files on the Hydstra database. Discharge measurements for the gage are listed under site gauging files on the Hydstra database.

Datum Correction. None. Levels were run in April 16, 2001, when gage was reestablished

Gage-Height Record. The 8210 data logger gave a complete and satisfactory record for the year.

Rating. The channel at the gage is about 8 feet wide and straight for about 50 feet upstream, then bends to the left and straight for 100 feet downstream. The streambed through this reach is primarily gravel with cobbles. The low flow control is a 120-degree sharp weir. Open channel will be the control for high flows.

Rating No. 2 is based on four discharge measurements and one critical depth computation, and theoretical computation for 120-degree crested weir to a gage height of 2.30 feet. Broad crested weir computation is used above that stage.

No discharge measurements were made this water year. Ten inspections of no flow were made during the period of record.

Discharge. Discharge was computed by applying Rating No. 2 direct with one variable shift. Discharge compared with station E256, which is downstream about 3 miles. No flow for the year.

Remarks. Records good. 


\section{E253 Cañon de Valle above SR 501}

Daily Mean Discharge in Cubic Feet per Second

Water Year October 2005 to September 2006

\begin{tabular}{|c|c|c|c|c|c|c|c|c|c|c|c|c|}
\hline DAY & OCT & NOV & DEC & JAN & FEB & MAR & APR & MAY & JUN & JUL & AUG & SEP \\
\hline 1 & 0 & 0 & 0 & 0 & 0 & 0 & 0 & 0 & 0 & 0 & 0 & 0 \\
\hline 2 & 0 & 0 & 0 & 0 & 0 & 0 & 0 & 0 & 0 & 0 & 0 & 0 \\
\hline 3 & 0 & 0 & 0 & 0 & 0 & 0 & 0 & 0 & 0 & 0 & 0 & 0 \\
\hline 4 & 0 & 0 & 0 & 0 & 0 & 0 & 0 & 0 & 0 & 0 & 0 & 0 \\
\hline 5 & 0 & 0 & 0 & 0 & 0 & 0 & 0 & 0 & 0 & 0 & 0 & 0 \\
\hline 6 & 0 & 0 & 0 & 0 & 0 & 0 & 0 & 0 & 0 & 0 & 0 & 0 \\
\hline 7 & 0 & 0 & 0 & 0 & 0 & 0 & 0 & 0 & 0 & 0 & 0 & 0 \\
\hline 8 & 0 & 0 & 0 & 0 & 0 & 0 & 0 & 0 & 0 & 0 & 0 & 0 \\
\hline 9 & 0 & 0 & 0 & 0 & 0 & 0 & 0 & 0 & 0 & 0 & 0 & 0 \\
\hline 10 & 0 & 0 & 0 & 0 & 0 & 0 & 0 & 0 & 0 & 0 & 0 & 0 \\
\hline 11 & 0 & 0 & 0 & 0 & 0 & 0 & 0 & 0 & 0 & 0 & 0 & 0 \\
\hline 12 & 0 & 0 & 0 & 0 & 0 & 0 & 0 & 0 & 0 & 0 & 0 & 0 \\
\hline 13 & 0 & 0 & 0 & 0 & 0 & 0 & 0 & 0 & 0 & 0 & 0 & 0 \\
\hline 14 & 0 & 0 & 0 & 0 & 0 & 0 & 0 & 0 & 0 & 0 & 0 & 0 \\
\hline 15 & 0 & 0 & 0 & 0 & 0 & 0 & 0 & 0 & 0 & 0 & 0 & 0 \\
\hline 16 & 0 & 0 & 0 & 0 & 0 & 0 & 0 & 0 & 0 & 0 & 0 & 0 \\
\hline 17 & 0 & 0 & 0 & 0 & 0 & 0 & 0 & 0 & 0 & 0 & 0 & 0 \\
\hline 18 & 0 & 0 & 0 & 0 & 0 & 0 & 0 & 0 & 0 & 0 & 0 & 0 \\
\hline 19 & 0 & 0 & 0 & 0 & 0 & 0 & 0 & 0 & 0 & 0 & 0 & 0 \\
\hline 20 & 0 & 0 & 0 & 0 & 0 & 0 & 0 & 0 & 0 & 0 & 0 & 0 \\
\hline 21 & 0 & 0 & 0 & 0 & 0 & 0 & 0 & 0 & 0 & 0 & 0 & 0 \\
\hline 22 & 0 & 0 & 0 & 0 & 0 & 0 & 0 & 0 & 0 & 0 & 0 & 0 \\
\hline 23 & 0 & 0 & 0 & 0 & 0 & 0 & 0 & 0 & 0 & 0 & 0 & 0 \\
\hline 24 & 0 & 0 & 0 & 0 & 0 & 0 & 0 & 0 & 0 & 0 & 0 & 0 \\
\hline 25 & 0 & 0 & 0 & 0 & 0 & 0 & 0 & 0 & 0 & 0 & 0 & 0 \\
\hline 26 & 0 & 0 & 0 & 0 & 0 & 0 & 0 & 0 & 0 & 0 & 0 & 0 \\
\hline 26 & 0 & 0 & 0 & 0 & 0 & 0 & 0 & 0 & 0 & 0 & 0 & 0 \\
\hline 27 & 0 & 0 & 0 & 0 & 0 & 0 & 0 & 0 & 0 & 0 & 0 & 0 \\
\hline 29 & 0 & 0 & 0 & 0 & ------ & 0 & 0 & 0 & 0 & 0 & 0 & 0 \\
\hline 30 & 0 & 0 & 0 & 0 & ------ & 0 & 0 & 0 & 0 & 0 & 0 & 0 \\
\hline 31 & 0 & -ב-ב-ב- & 0 & 0 & --.-- & 0 & ----- & 0 & ----- & 0 & 0 & - ב-ב-ב- \\
\hline Total & 0 & 0 & 0 & 0 & 0 & 0 & 0 & 0 & 0 & 0 & 0 & 0 \\
\hline Mean & 0 & 0 & 0 & 0 & 0 & 0 & 0 & 0 & 0 & 0 & 0 & 0 \\
\hline Max & 0 & 0 & 0 & 0 & 0 & 0 & 0 & 0 & 0 & 0 & 0 & 0 \\
\hline Min & 0 & 0 & 0 & 0 & 0 & 0 & 0 & 0 & 0 & 0 & 0 & 0 \\
\hline Acre-Ft & 0 & 0 & 0 & 0 & 0 & 0 & 0 & 0 & 0 & 0 & 0 & 0 \\
\hline Wtr Year & 2006 & Total & 0 & Mean & 0 & & Max & 0 & Min & 0 & Acre-Ft & 0 \\
\hline Cal Year & 2005 & Total & 65.02 & Mean & .18 & & Max & 6.9 & Min & 0 & Acre-Ft & 129 \\
\hline
\end{tabular}




\section{E256 Cañon de Valle below MDA P}

Location. Lat. 3551'01", long. 106¹9'57", T.19 N, R 6 E, Ramon Vigil Grant Los Alamos County, on right bank, 2.0 miles northwest of DX, and 2.1 miles west of SR 501.

Drainage Area. $3.13 \mathrm{mi}^{2}$.

Period of Record. January 24, 2002, to September 30, 2006.

Revised Record. Drainage Area (this report).

Gage. Data logger with cellular telemetry and 2-ft Parshall flume. Elevation of gage is 7,329 $\mathrm{ft}$ above NGVD from GIS 9.1.

Remarks. Water discharge records good, except for estimated daily discharges, which are poor.

Extremes for Period of Record. Maximum discharge $19 \mathrm{ft}^{3}$ /s, August 24, 2005, gage height $1.74 \mathrm{ft}$. No flow most of time.

Extremes for Current Year. Maximum discharge $14 \mathrm{ft}^{3} / \mathrm{s}$ at $1250 \mathrm{~h}$, September 11, gage height $1.44 \mathrm{ft}$. No flow at times.

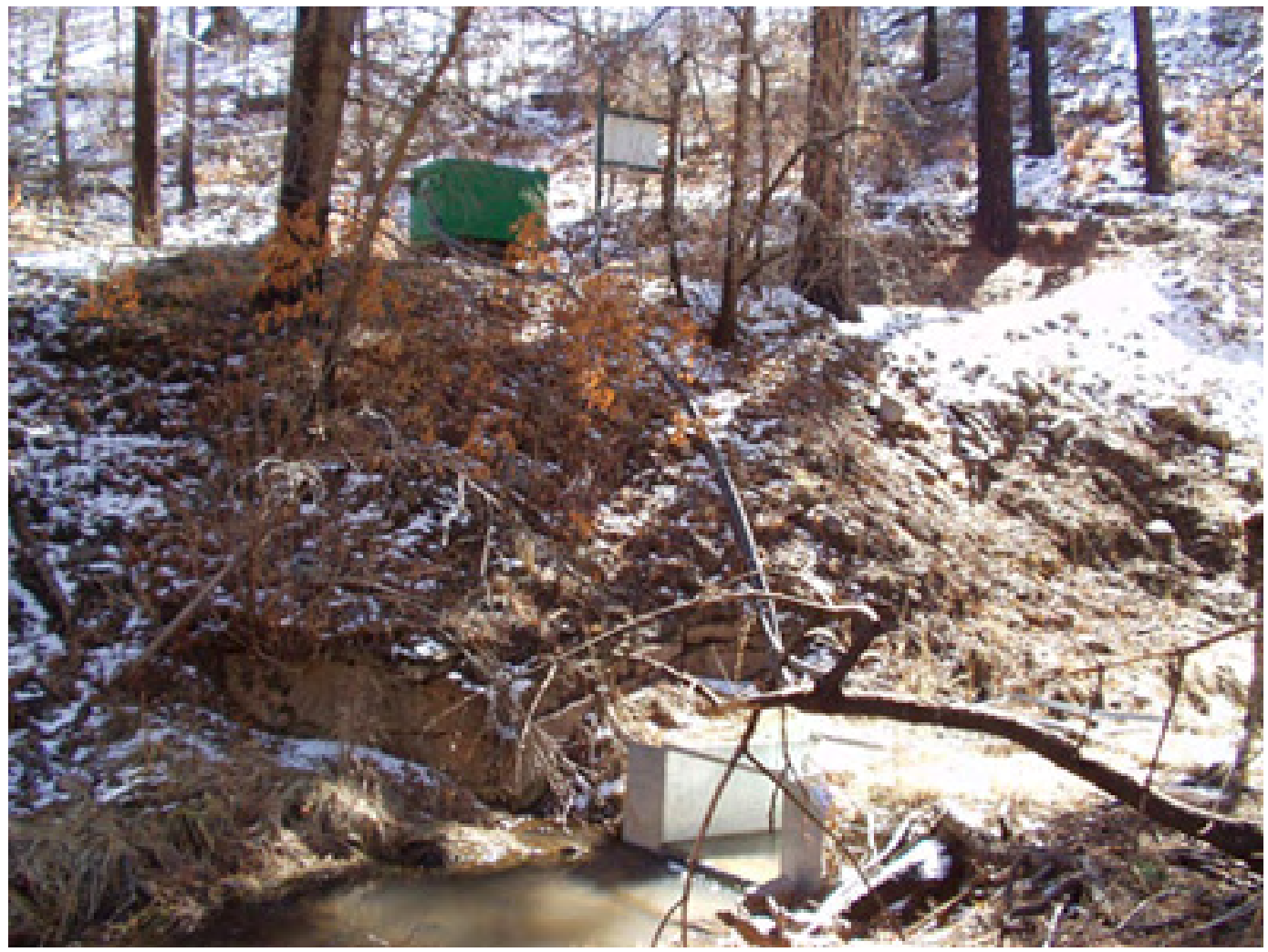




\section{E256 Cañon de Valle Below MDA P \\ Station Analysis \\ 2006 Water Year}

Equipment. Sutron 8210 data logger (5-min. interval) with cellular phone and speech modem housed in a NEMA shelter on left bank. Bubble gage is sensing device and outside is reference gage. An ISCO brand automatic sampler is housed in a 4' $\times 4^{\prime}$ metal box, and is triggered by the data logger. No provision for direct measurements above wading stage.

Field Work. The station was visited fifteen times for the purpose of making a discharge measurement and/or servicing the instrumentation. Field inspections for the gage are listed under site history files on the Hydstra database. Discharge measurements for the gage are listed under site gauging files on the Hydstra database.

Datum Correction. None.

Gage-Height Record. The data logger referenced to the inside staff gave a complete and satisfactory record except for the following date: December 5 to February 28 when gage was affected by ice.

Rating. The channel is straight for 50 feet upstream and 20 feet downstream from gage. The streambed is sand with ravel subject to fill behind flume from flow events and gage silting problems. The banks are covered with vegetation.

Rating No. 1 is based on 2-foot Parshall flume.

Two discharge measurements (No. 6-7) and thirteen observations of no flow were made.

Discharge. Discharge computed from Rating 1 using variable shift diagrams. Period of lost or ice-affected record was estimated using weather data, tech notes, and comparison with E253.

Remarks. Records good, except for estimated daily discharges which are poor. 


\section{E256 Cañon de Valle below MDA P}

Daily Mean Discharge in Cubic Feet per Second

Water Year October 2005 to September 2006

\begin{tabular}{|c|c|c|c|c|c|c|c|c|c|c|c|c|}
\hline DAY & OCT & NOV & DEC & JAN & FEB & MAR & APR & MAY & JUN & JUL & AUG & SEP \\
\hline 1 & .09 & .08 & .11 & $0^{*}$ & $0^{*}$ & .07 & .06 & .01 & 0 & 0 & 0 & .41 \\
\hline 2 & .09 & .07 & .10 & $0^{*}$ & $0^{*}$ & .07 & .06 & .01 & 0 & 0 & 0 & .11 \\
\hline 3 & .10 & .07 & 11 & $0^{*}$ & $0^{*}$ & .07 & .06 & .01 & 0 & .01 & 0 & .10 \\
\hline 4 & .10 & .07 & .11 & $0^{*}$ & $0^{*}$ & .07 & .06 & .01 & 0 & 0 & 0 & .09 \\
\hline 5 & .12 & .08 & $0^{*}$ & $0^{*}$ & $0^{*}$ & .06 & .07 & .01 & 0 & 0 & .03 & .08 \\
\hline 6 & .13 & .09 & $0^{*}$ & $0^{*}$ & $0^{*}$ & .07 & .07 & .01 & 0 & 0 & .01 & .09 \\
\hline 7 & .13 & .09 & $0^{*}$ & $0^{*}$ & $0^{*}$ & .07 & .06 & .01 & 0 & 0 & .04 & .08 \\
\hline 8 & .20 & .09 & $0^{*}$ & $0^{*}$ & $0^{*}$ & .07 & .06 & .01 & 0 & .01 & .31 & .08 \\
\hline 9 & .28 & .10 & $0^{*}$ & $0^{*}$ & $0^{*}$ & .06 & .05 & 0 & 0 & 0 & .06 & .08 \\
\hline 10 & .19 & .01 & $0^{*}$ & $0^{*}$ & $0^{*}$ & .06 & .05 & .01 & 0 & 0 & .03 & .07 \\
\hline 11 & .16 & .12 & $0^{*}$ & $0^{*}$ & $0^{*}$ & .06 & .05 & 0 & 0 & 0 & .02 & .87 \\
\hline 12 & .16 & .12 & $0^{*}$ & $0^{*}$ & $0^{*}$ & .07 & .04 & 0 & 0 & 0 & .02 & .15 \\
\hline 13 & .15 & .12 & $0^{*}$ & $0^{*}$ & $0^{*}$ & .09 & .03 & 0 & 0 & 0 & .03 & .13 \\
\hline 14 & .13 & .12 & $0^{*}$ & $0^{*}$ & $0^{*}$ & .05 & .02 & .01 & 0 & 0 & .03 & .12 \\
\hline 15 & .14 & .11 & $0^{*}$ & $0^{*}$ & $0^{*}$ & .06 & .02 & .01 & 0 & 0 & .04 & .12 \\
\hline 16 & .13 & .11 & $0^{*}$ & $0^{*}$ & $0^{*}$ & .06 & .01 & .01 & 0 & 0 & .03 & .11 \\
\hline 17 & .13 & .11 & $0^{*}$ & $0^{*}$ & $0^{*}$ & .06 & .01 & 0 & 0 & 0 & .03 & .11 \\
\hline 18 & .12 & .10 & $0^{*}$ & $0^{*}$ & $0^{*}$ & .05 & .01 & 0 & 0 & 0 & .03 & .10 \\
\hline 19 & .11 & .11 & $0^{*}$ & $0^{*}$ & $0^{*}$ & .05 & .01 & 0 & 0 & 0 & .03 & .10 \\
\hline 20 & .10 & .11 & $0^{*}$ & $0^{*}$ & $0^{*}$ & .05 & .01 & 0 & 0 & 0 & .05 & .10 \\
\hline 21 & .10 & .11 & $0^{*}$ & $0^{*}$ & $0^{*}$ & .06 & .01 & 0 & 0 & 0 & .04 & .10 \\
\hline 22 & .10 & .11 & $0^{*}$ & $0^{*}$ & $0^{*}$ & .06 & .01 & 0 & 0 & 0 & .04 & .11 \\
\hline 23 & .10 & .09 & $0^{*}$ & $0^{*}$ & $0^{*}$ & .06 & .01 & 0 & 0 & 0 & .04 & .10 \\
\hline 24 & .09 & .11 & $0^{*}$ & $0^{*}$ & $0^{*}$ & .06 & .01 & 0 & 0 & 0 & .03 & .10 \\
\hline 25 & .09 & .11 & $0^{*}$ & $0^{*}$ & $0^{*}$ & .07 & .01 & 0 & 0 & 0 & .78 & .10 \\
\hline 26 & .09 & .11 & $0^{*}$ & $0^{*}$ & $0^{*}$ & .07 & .01 & 0 & 0 & 0 & .20 & .09 \\
\hline 27 & .09 & .11 & $0^{*}$ & $0^{*}$ & $0^{*}$ & .06 & .01 & 0 & 0 & 0 & .17 & .09 \\
\hline 28 & .09 & .11 & $0^{*}$ & $0^{*}$ & .07 & .07 & .03 & 0 & 0 & 0 & .15 & .08 \\
\hline 29 & .09 & .13 & $0^{*}$ & $0^{*}$ & ----- & .07 & .03 & 0 & .04 & 0 & .16 & .08 \\
\hline 30 & .08 & .12 & $0^{*}$ & $0^{*}$ & ----- & .06 & .02 & 0 & 0 & 0 & .18 & .08 \\
\hline 31 & .09 & ----- & $0^{*}$ & $0^{*}$ & ------ & .06 & ----- & 0 & ------ & 0 & .16 & ב---- \\
\hline Total & 3.77 & 2.99 & 0.43 & 0 & 0.07 & 1.97 & 0.96 & 0.12 & 0.04 & 0.02 & 2.74 & 4.03 \\
\hline Mean & .12 & .10 & .014 & 0 & .003 & .064 & .032 & .004 & .001 & .001 & .088 & .13 \\
\hline Max & .28 & .13 & .11 & 0 & .07 & .09 & .07 & .01 & .04 & .01 & .78 & .87 \\
\hline Min & .08 & .01 & 0 & 0 & 0 & .05 & .01 & 0 & 0 & 0 & 0 & .07 \\
\hline Acre-Ft & 7.5 & 5.9 & .85 & 0 & .14 & 3.9 & 1.9 & .24 & .08 & .04 & 5.4 & 8.0 \\
\hline Wtr Year & 2006 & Total & 17.14 & & & & Max & 87 & Min & 0 & Acre-Ft & 34 \\
\hline Cal Year & 2005 & Total & 72.72 & & & & Max & & Min & 0 & Acre-Ft & 144 \\
\hline
\end{tabular}




\section{E262 Cañon de Valle above Water}

Location. Lat. 3549'51", long. 106 18'14", in Ramon Vigil Grant, Los Alamos County, on right bank $200 \mathrm{ft}$ above confluence with Water Canyon, 1.6 miles upstream from E262.5 and 4.2 miles upstream from SR 4.

Drainage Area. $4.32 \mathrm{mi}^{2}$.

Period of Record. October 1998 to September 30, 2006.

Revised Record. Drainage Area (this report).

Gage. Data logger with cellular telemetry and $90^{\circ}$ weir plate. Elevation of gage is $6,812 \mathrm{ft}$ above NGVD from GIS 9.1.

Remarks. Records good.

Average Discharge. $7 \mathrm{yr} \mathrm{ft} / \mathrm{s}, 0.01,7.2$ acre-ft/yr.

Extremes for Period of Record. Maximum discharge $63 \mathrm{ft}^{3} / \mathrm{s}$, August 20, 2004, gage height $4.10 \mathrm{ft}$. No flow most of time.

Extremes for Current Water Year. Maximum discharge $59 \mathrm{ft}^{3} / \mathrm{s}$ at $1305 \mathrm{~h}$, August 25, gage height $4.05 \mathrm{ft}$. No flow most of time.

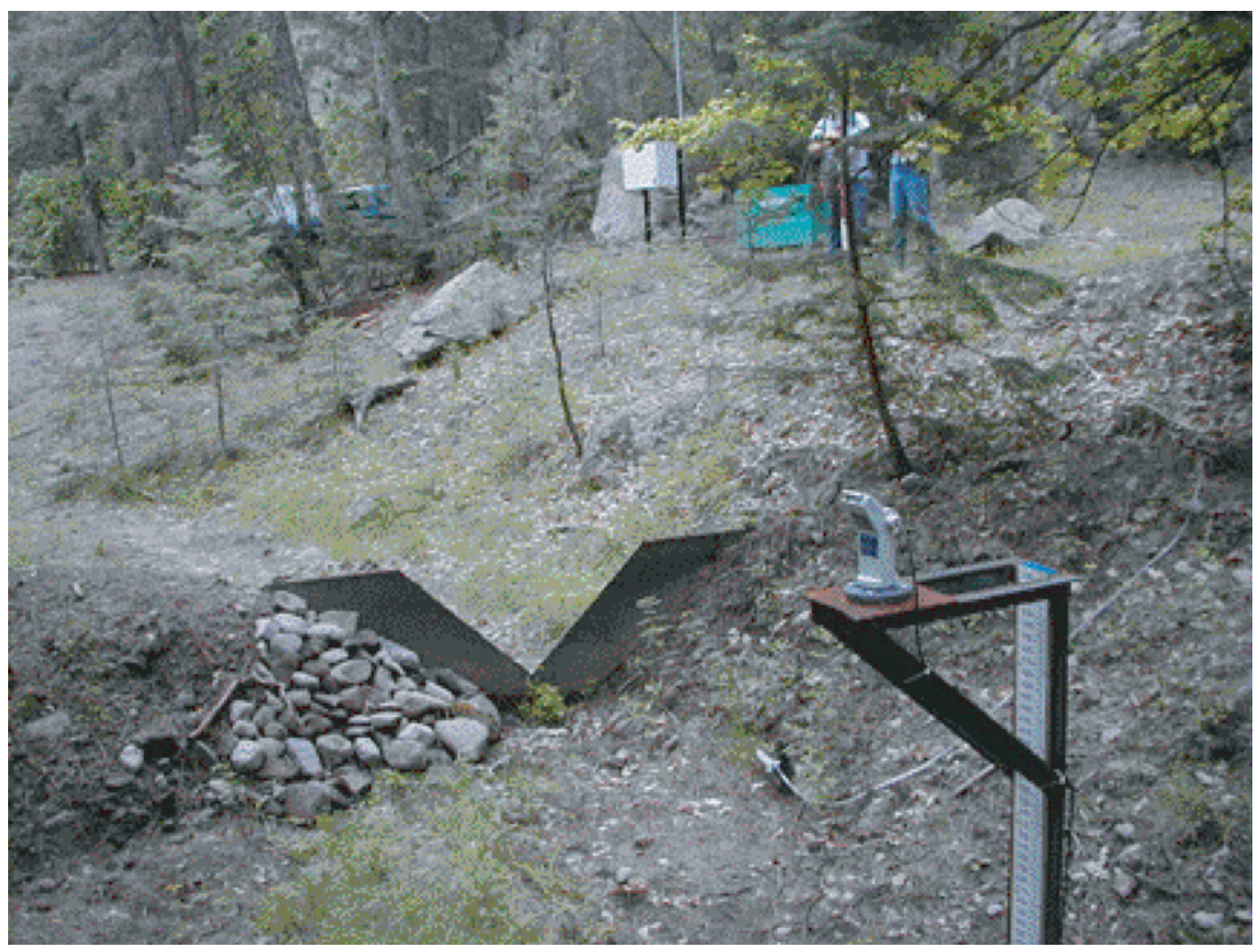




\section{E262 Cañon de Valle above Water \\ Station Analysis \\ 2006 Water Year}

Equipment. Sutron 8210 data logger (5-min. interval) with cellular phone and speech modem housed in a NEMA shelter on left bank. The stage sensor is a milltronics sonic probe mounted on a 6" channel spanning into stream. The equipment is powered by a solar panel charging system. The gaging station is also equipped with an ISCO pump sampler for water quality collection in a $4^{\prime} \times 4^{\prime}$ metal box. An outside staff is available for reference. No provisions are made for measurement above wading stage.

Field Work. The station was visited fourteen times for the purpose of making a discharge measurement and/or servicing the instrumentation. Field inspections for the gage are listed under site history files on the Hydstra database. Discharge measurements for the gage are listed under site gauging files on the Hydstra database.

Datum Correction. None.

Gage-Height Record. The data logger referenced to the outside staff gave a complete and satisfactory record except for March 23 to April 27 when data logger lost power and August 28 to September 10, September 13-30, when probe became isolated from flow.

Rating. The channel is about 10 feet wide and straight for about 50 feet upstream and straight for about 30 feet downstream. The streambed through this reach is primarily with gravel, sand, and cobbles.

Rating No. 1 is based on a theoretical computation for 90 degree sharp-crested weir up to a gage height of 2.95 feet. Broad-crested weir computation is used above that stage.

One discharge measurement (No. 10) and thirteen inspections of no flow were made during the water year.

Discharge. Discharge was computed by applying Rating No. 1 direct with six variable shifts during the spring runoff. Reworked days were all determined to be zero flow.

Remarks. Records good, except for estimated daily discharges, which are poor. 


\section{E262 Cañon de Valle above Water}

Daily Mean Discharge in Cubic Feet per Second

Water Year October 2005 to September 2006

\begin{tabular}{|c|c|c|c|c|c|c|c|c|c|c|c|c|}
\hline DAY & OCT & NOV & DEC & JAN & FEB & MAR & APR & MAY & JUN & JUL & AUG & SEP \\
\hline 1 & 0 & 0 & 0 & 0 & 0 & 0 & $0^{*}$ & 0 & 0 & 0 & 0 & $0^{*}$ \\
\hline 2 & 0 & 0 & 0 & 0 & 0 & 0 & $0^{*}$ & 0 & 0 & 0 & 0 & $0^{*}$ \\
\hline 3 & 0 & 0 & 0 & 0 & 0 & 0 & $0^{*}$ & 0 & 0 & 0 & 0 & $0^{*}$ \\
\hline 4 & 0 & 0 & 0 & 0 & 0 & 0 & $0^{*}$ & 0 & 0 & 0 & 0 & $0^{*}$ \\
\hline 5 & 0 & 0 & 0 & 0 & 0 & 0 & $0^{*}$ & 0 & 0 & 0 & 0 & $0^{*}$ \\
\hline 6 & 0 & 0 & 0 & 0 & 0 & 0 & $0^{*}$ & 0 & 0 & 0 & 0 & $0^{*}$ \\
\hline 7 & 0 & 0 & 0 & 0 & 0 & 0 & $0^{*}$ & 0 & 0 & 0 & 0 & $0^{*}$ \\
\hline 8 & 0 & 0 & 0 & 0 & 0 & 0 & $0^{*}$ & 0 & 0 & 0 & 0 & $0^{*}$ \\
\hline 9 & 0 & 0 & 0 & 0 & 0 & 0 & $0^{*}$ & 0 & 0 & 0 & 0 & $0^{*}$ \\
\hline 10 & 0 & 0 & 0 & 0 & 0 & 0 & $0^{*}$ & 0 & 0 & 0 & 0 & $0^{*}$ \\
\hline 11 & 0 & 0 & 0 & 0 & 0 & 0 & $0^{*}$ & 0 & 0 & 0 & 0 & .09 \\
\hline 12 & 0 & 0 & 0 & 0 & 0 & 0 & $0^{*}$ & 0 & 0 & 0 & 0 & .02 \\
\hline 13 & 0 & 0 & 0 & 0 & 0 & 0 & $0^{*}$ & 0 & 0 & 0 & 0 & $0^{*}$ \\
\hline 14 & 0 & 0 & 0 & 0 & 0 & 0 & $0^{*}$ & 0 & 0 & 0 & 0 & $0^{*}$ \\
\hline 15 & 0 & 0 & 0 & 0 & 0 & 0 & $0^{*}$ & 0 & 0 & 0 & 0 & $0^{*}$ \\
\hline 16 & 0 & 0 & 0 & 0 & 0 & 0 & $0^{*}$ & 0 & 0 & 0 & 0 & $0^{*}$ \\
\hline 17 & 0 & 0 & 0 & 0 & 0 & 0 & $0^{*}$ & 0 & 0 & 0 & 0 & $0^{*}$ \\
\hline 18 & 0 & 0 & 0 & 0 & 0 & 0 & $0^{*}$ & 0 & 0 & 0 & 0 & $0^{*}$ \\
\hline 19 & 0 & 0 & 0 & 0 & 0 & 0 & $0^{*}$ & 0 & 0 & 0 & 0 & $0^{*}$ \\
\hline 20 & 0 & 0 & 0 & 0 & 0 & 0 & $0^{*}$ & 0 & 0 & 0 & 0 & $0^{*}$ \\
\hline 21 & 0 & 0 & 0 & 0 & 0 & 0 & $0^{*}$ & 0 & 0 & 0 & 0 & $0^{*}$ \\
\hline 22 & 0 & 0 & 0 & 0 & 0 & 0 & $0^{*}$ & 0 & 0 & 0 & 0 & $0^{*}$ \\
\hline 23 & 0 & 0 & 0 & 0 & 0 & $0^{*}$ & $0^{*}$ & 0 & 0 & 0 & 0 & $0^{*}$ \\
\hline 24 & 0 & 0 & 0 & 0 & 0 & $0^{*}$ & $0^{*}$ & 0 & 0 & 0 & 0 & $0^{*}$ \\
\hline 25 & 0 & 0 & 0 & 0 & 0 & $0^{*}$ & $0^{*}$ & 0 & 0 & 0 & 2.7 & $0^{*}$ \\
\hline 26 & 0 & 0 & 0 & 0 & 0 & $0^{*}$ & $0^{*}$ & 0 & 0 & 0 & .09 & $0^{*}$ \\
\hline 27 & 0 & 0 & 0 & 0 & 0 & $0^{*}$ & $0^{*}$ & 0 & 0 & 0 & .07 & $0^{*}$ \\
\hline 28 & 0 & 0 & 0 & 0 & 0 & $0^{*}$ & 0 & 0 & 0 & 0 & $.01^{*}$ & $0^{*}$ \\
\hline 29 & 0 & 0 & 0 & 0 & ------ & $0^{*}$ & 0 & 0 & 0 & 0 & $0^{*}$ & $0^{*}$ \\
\hline 30 & 0 & 0 & 0 & 0 & ----- & $0^{*}$ & 0 & 0 & 0 & 0 & $0^{*}$ & $0^{*}$ \\
\hline 31 & 0 & ---- & 0 & 0 & ----- & $0^{*}$ & ----- & 0 & ---- & 0 & $0^{*}$ & ------ \\
\hline Total & 0 & 0 & 0 & 0 & 0 & 0 & 0 & 0 & 0 & 0 & 2.87 & 0.11 \\
\hline Mean & 0 & 0 & 0 & 0 & 0 & 0 & 0 & 0 & 0 & 0 & .093 & .004 \\
\hline Max & 0 & 0 & 0 & 0 & 0 & 0 & 0 & 0 & 0 & 0 & 2.7 & .09 \\
\hline Min & 0 & 0 & 0 & 0 & 0 & 0 & 0 & 0 & 0 & 0 & 0 & 0 \\
\hline Acre-Ft & 0 & 0 & 0 & 0 & 0 & 0 & 0 & 0 & 0 & 0 & 5.7 & .22 \\
\hline Wtr Year & 2006 & Total & 2.98 & Mean & .008 & & $\operatorname{Max}$ & & Min & & Acre-Ft & 5.9 \\
\hline Cal Year & 2005 & Total & 25.43 & Mean & .070 & & Max & & Min & & Acre-Ft & 50 \\
\hline
\end{tabular}




\section{E2625 Water below MDA AB}

Location. Lat. 35'49'31', long. 106 $17^{\prime}$ '03', in Ramon Vigil Grant, Los Alamos County, on left bank 1.6 miles downstream from E262, 2.6 miles upstream from SR 4 and 4.6 miles northeast of Pajarito Road junction.

Drainage Area. $11.55 \mathrm{mi}^{2}$.

Period of Record. May 1 to September 30, 2006.

Revised Record. Drainage Area (this report)

Gage. Data logger with cellular telemetry and $90^{\circ}$ weir plate. Elevation of gage is $6,666 \mathrm{ft}$ above NGVD from GIS 9.1.

Remarks. Records fair except for estimated daily discharges, which are poor.

Extremes for Period of Record. Maximum discharge $195 \mathrm{ft}^{3} / \mathrm{s}$, August 25, 2006, gage height $4.30 \mathrm{ft}$; no flow most of time.

Extremes for Current Water Year. Maximum discharge $195 \mathrm{ft}^{3} / \mathrm{s}$ at $1330 \mathrm{~h}$, August 25, gage height, $4.30 \mathrm{ft}$. No flow most of time.

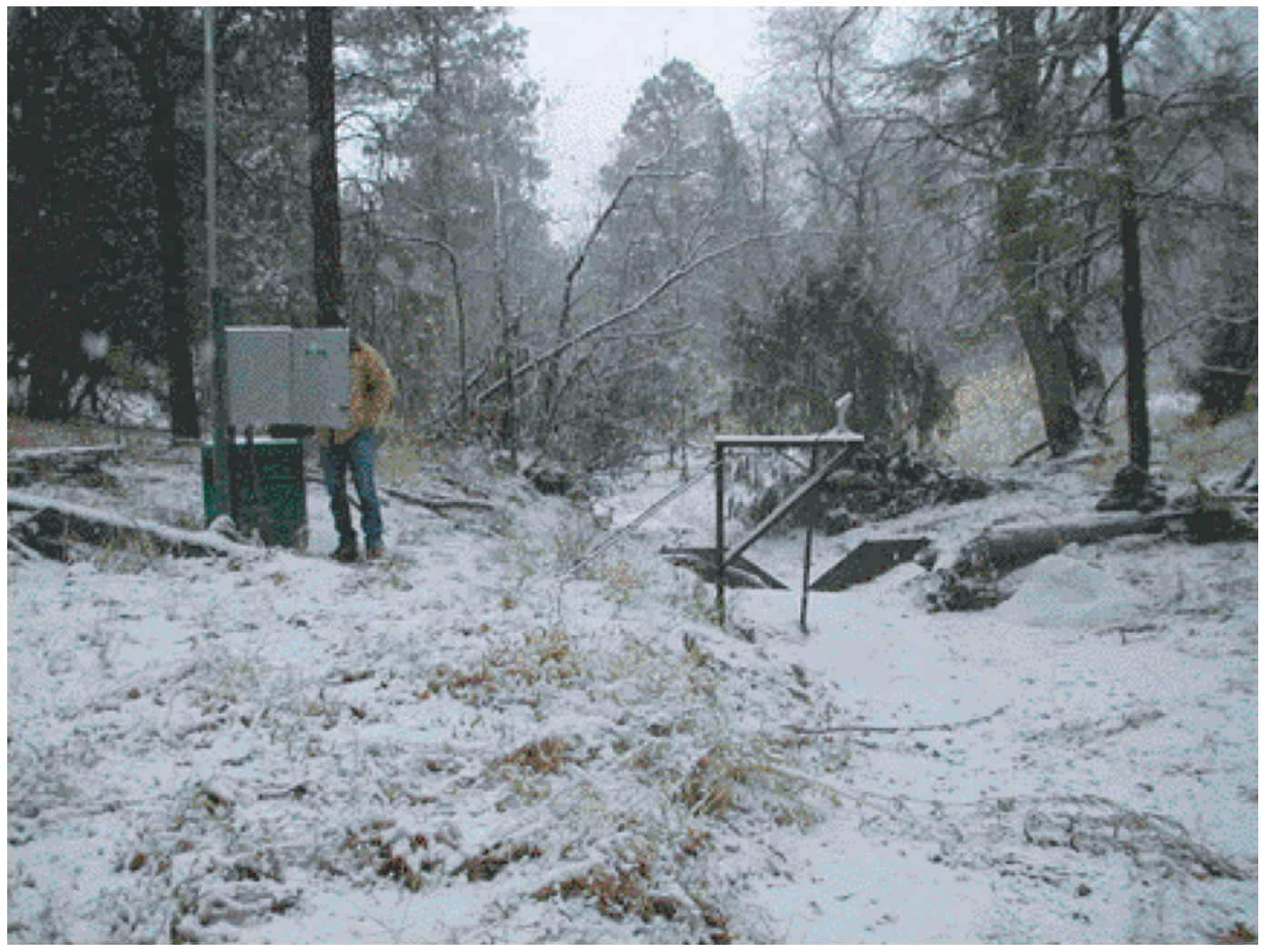




\section{E2625 Water below MDA AB \\ Station Analysis \\ 2006 Water Year}

Equipment. Sutron 8210 data logger (5-min. interval) with cellular phone and speech modem housed in a NEMA shelter on right bank. The stage sensor is milltronics sonic probe mounted on a 6" channel cantilevered over stream. The equipment is powered by a solar charging system. The gaging station is also equipped with an ISCO pump sampler for water-quality collection in a $4^{\prime} \times 4^{\prime}$ metal box. The outside staff is the reference gage. No provisions are made for measurement above wading stage.

Field Work. The station was visited fifteen times for the purpose of making a discharge measurement and/or servicing the instrumentation. Field inspections for the gage are listed under site history files on the Hydstra database. Discharge measurements for the gage are listed under site gauging files on the Hydstra database.

Datum Correction. None. Levels on May 7, 2001 were run when gage was established.

Gage-Height Record. The data logger referenced to the outside staff gave a complete and satisfactory record for the year except for the following days: November 2 to January 19 when gage height was affected by ice.

Rating. The channel is about 20 feet wide and straight for about 75 feet upstream and straight for about 100 feet downstream. The streambed through this reach is primarily with sand and cobbles. The low water control is a 90 degrees shape weir. Open channel will be the control for high flows.

Two discharge measurements (No. 14-15) and thirteen visits of no flow were made during the year. All inspections of no flow were used to develop a "V" diagram shift need to adjust for PZF.

Rating No. 2 is based on a theoretical computation for 90 degrees shape-crested weir up to a gage height of 2.75 feet and extended to $4.38 \mathrm{ft}$. gage height based on a slope area measurement. Measurements plotted -0.23 and -0.19 , respectively. These shifts were applied to low flow using "V" diagrams. Large negatives (about $0.5 \mathrm{ft}$ ) were also applied to zero flow observations.

Discharge. Discharge was computed by applying gage height to Rating No. 2 through shift adjustment based on "V" diagrams. Record for estimated daily discharges were based on precipitation record and field notes and some comparison with E262 and E2525.

Remarks. Records good, except for estimated daily discharges which are poor. 


\section{E2625 Water below MDA AB}

Daily Mean Discharge in Cubic Feet per Second

Water Year October 2005 to September 2006

\begin{tabular}{|c|c|c|c|c|c|c|c|c|c|c|c|c|}
\hline DAY & OCT & NOV & DEC & JAN & FEB & MAR & APR & MAY & JUN & JUL & AUG & SEP \\
\hline 1 & .16 & .09 & $0^{*}$ & $0^{*}$ & 0 & 0 & 0 & 0 & 0 & 0 & 0 & .76 \\
\hline 2 & .10 & $.08^{*}$ & $0^{*}$ & $0^{*}$ & 0 & 0 & 0 & 0 & 0 & 0 & 0 & .55 \\
\hline 3 & .08 & $.08^{*}$ & $0^{*}$ & $0^{*}$ & 0 & 0 & 0 & 0 & 0 & 0 & 0 & .40 \\
\hline 4 & .09 & $.07^{*}$ & $0^{*}$ & $0^{*}$ & 0 & 0 & 0 & 0 & 0 & 0 & 0 & .31 \\
\hline 5 & .06 & $.06^{*}$ & $0^{*}$ & $0^{*}$ & 0 & 0 & 0 & 0 & 0 & 0 & 0 & .27 \\
\hline 6 & .08 & $.06^{*}$ & $0^{*}$ & $0^{*}$ & 0 & 0 & 0 & 0 & 0 & 0 & 0 & .27 \\
\hline 7 & .08 & $.05^{\star}$ & $0^{*}$ & $0^{*}$ & 0 & 0 & 0 & 0 & 0 & 0 & 0 & .32 \\
\hline 8 & .09 & $.04^{*}$ & $0^{*}$ & $0^{*}$ & 0 & 0 & 0 & 0 & 0 & 0 & 0 & .32 \\
\hline 9 & .10 & $.04^{*}$ & $0^{*}$ & $0^{*}$ & 0 & 0 & 0 & 0 & 0 & 0 & 0 & .32 \\
\hline 10 & .13 & $.03^{*}$ & $0^{*}$ & $0^{*}$ & 0 & 0 & 0 & 0 & 0 & 0 & 0 & .31 \\
\hline 11 & .11 & $.03^{*}$ & $0^{*}$ & $0^{*}$ & 0 & 0 & 0 & 0 & 0 & 0 & 0 & .96 \\
\hline 12 & .11 & $.02^{\star}$ & $0^{*}$ & $0^{*}$ & 0 & 0 & 0 & 0 & 0 & 0 & 0 & .39 \\
\hline 13 & .10 & $.02^{*}$ & $0^{*}$ & $0^{*}$ & 0 & 0 & 0 & 0 & 0 & 0 & 0 & .27 \\
\hline 14 & .10 & $.02^{*}$ & $0^{*}$ & $0^{*}$ & 0 & 0 & 0 & 0 & 0 & 0 & .24 & .21 \\
\hline 15 & .13 & $.01^{*}$ & $0^{*}$ & $0^{*}$ & 0 & 0 & 0 & 0 & 0 & 0 & .24 & .19 \\
\hline 16 & .13 & $.01^{*}$ & $0^{*}$ & $0^{*}$ & 0 & 0 & 0 & 0 & 0 & 0 & .18 & .16 \\
\hline 17 & .12 & $0^{*}$ & $0^{*}$ & $0^{*}$ & 0 & 0 & 0 & 0 & 0 & 0 & .18 & .14 \\
\hline 18 & .12 & $0^{*}$ & $0^{*}$ & $0^{*}$ & 0 & 0 & 0 & 0 & 0 & 0 & .17 & .13 \\
\hline 19 & .15 & $0^{*}$ & $0^{*}$ & $0^{*}$ & 0 & 0 & 0 & 0 & 0 & 0 & .19 & .13 \\
\hline 20 & .13 & $0^{*}$ & $0^{*}$ & 0 & 0 & 0 & 0 & 0 & 0 & 0 & .19 & .14 \\
\hline 21 & .13 & $0^{*}$ & $0^{*}$ & 0 & 0 & 0 & 0 & 0 & 0 & 0 & .32 & .14 \\
\hline 22 & .13 & $0^{*}$ & $0^{*}$ & 0 & 0 & 0 & 0 & 0 & 0 & 0 & .16 & .13 \\
\hline 23 & .12 & $0^{*}$ & $0^{*}$ & 0 & 0 & 0 & 0 & 0 & 0 & 0 & .09 & .11 \\
\hline 24 & .12 & $0^{*}$ & $0^{*}$ & 0 & 0 & 0 & 0 & 0 & 0 & 0 & .02 & .10 \\
\hline 25 & .13 & $0^{*}$ & $0^{*}$ & 0 & 0 & 0 & 0 & 0 & 0 & 0 & 5.9 & .10 \\
\hline 26 & .13 & $0^{*}$ & $0^{*}$ & 0 & 0 & 0 & 0 & 0 & 0 & 0 & .66 & .09 \\
\hline 27 & .13 & $0^{*}$ & $0^{*}$ & 0 & 0 & 0 & 0 & 0 & 0 & 0 & .36 & .09 \\
\hline 28 & .11 & $0^{*}$ & $0^{*}$ & 0 & 0 & 0 & 0 & 0 & 0 & 0 & .29 & .08 \\
\hline 29 & .10 & $0^{*}$ & $0^{*}$ & 0 & ------ & 0 & 0 & 0 & 1.1 & 0 & .25 & .08 \\
\hline 30 & .10 & $0^{*}$ & $0^{*}$ & 0 & ------ & 0 & 0 & 0 & .01 & 0 & .20 & .08 \\
\hline 31 & .09 & ----- & $0^{*}$ & 0 & ----- & 0 & ----- & 0 & ------ & 0 & .14 & ----- \\
\hline Total & 3.46 & 0.71 & 0 & 0 & 0 & 0 & 0 & 0 & 1.11 & 0 & 9.78 & 7.55 \\
\hline Mean & .11 & .024 & 0 & 0 & 0 & 0 & 0 & 0 & .037 & 0 & .32 & .25 \\
\hline Max & .16 & .09 & 0 & 0 & 0 & 0 & 0 & 0 & 1.1 & 0 & 5.9 & .96 \\
\hline Min & .06 & 0 & 0 & 0 & 0 & 0 & 0 & 0 & 0 & 0 & 0 & .08 \\
\hline Acre-Ft & 6.9 & 1.4 & 0 & 0 & 0 & 0 & 0 & 0 & 2.2 & 0 & 19 & 15 \\
\hline Wtr Year & 2006 & Total & 22.61 & Mean & .062 & & Max & 5.9 & Min & 0 & Acre-Ft & 45 \\
\hline Cal Year & 2005 & Total & 230.76 & Mean & .63 & & Max & 7.0 & Min & 0 & Acre-Ft & 458 \\
\hline
\end{tabular}




\section{E263 Water at SR 4}

Location. Lat. 3548'20", long. $106^{\circ} 14^{\prime} 52^{\prime \prime}$ in Ramon Vigil Grant, Los Alamos County, on right bank $50 \mathrm{ft}$ downstream from SR 4, $150 \mathrm{ft}$ above mouth of Indio Canyon, and 4.0 miles southwest of White Rock, New Mexico.

Drainage Area. $12.43 \mathrm{mi}^{2}$.

Period of Record. April 1999 to September 30, 2006.

Revised Record. Drainage Area (this report).

Gage. Data logger with cellular telemetry. Elevation of gage is 6,365 ft above NGVD from GIS 9.1.

Remarks. Water discharge records good except for estimated daily discharges, which are poor.

Extremes for Period of Record. Maximum discharge $306 \mathrm{ft}^{3} / \mathrm{s}$, June 28, 2000, gage height $3.78 \mathrm{ft}$. No flow most of time.

Extremes for Current Water Year. Maximum discharge $66 \mathrm{ft}^{3} / \mathrm{s}$ at $1420 \mathrm{~h}$, August 25, gage height $1.84 \mathrm{ft}$. No flow most of time.

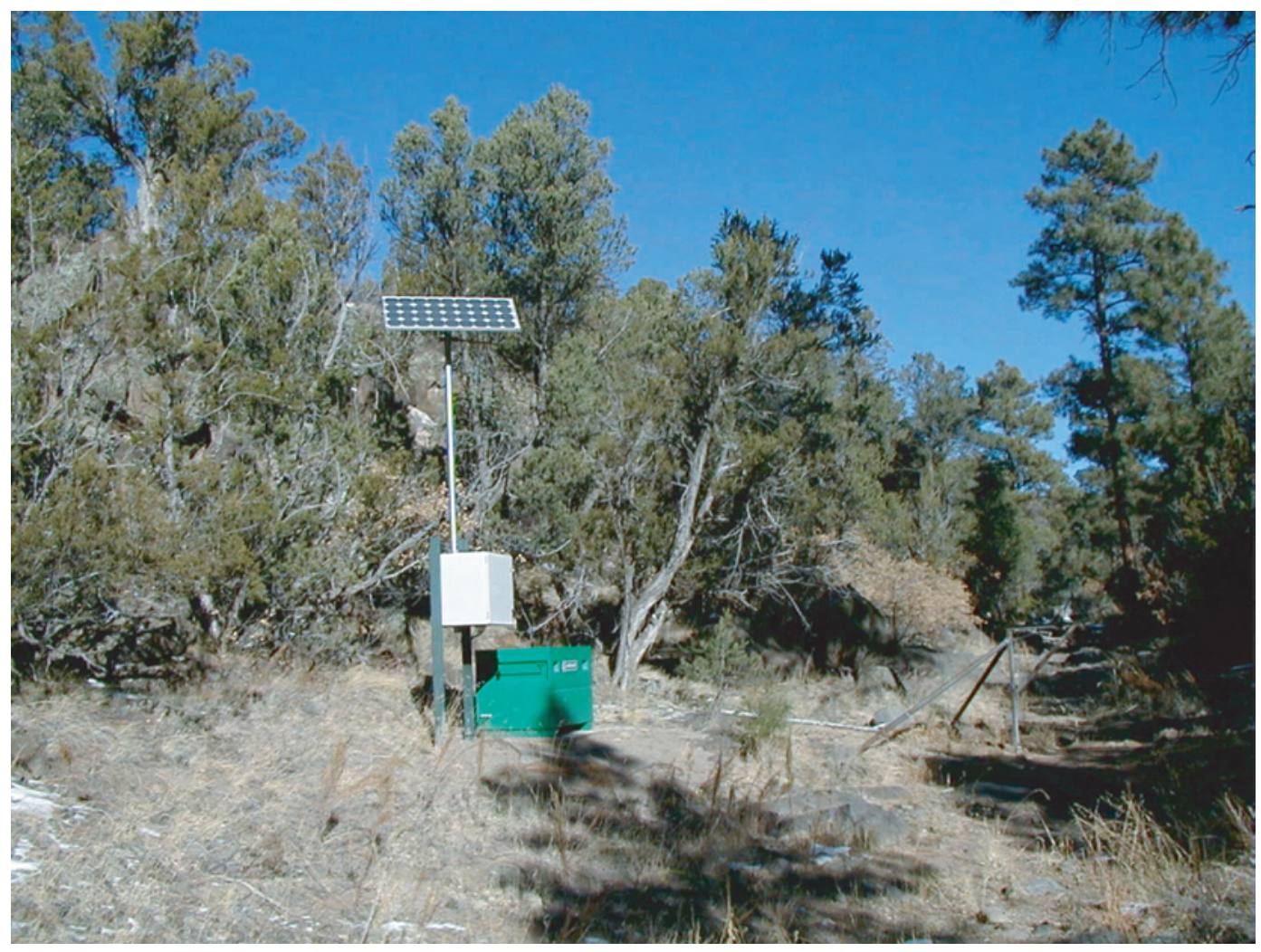




\section{E263 Water at SR 4}

\section{Station Analysis}

2006 Water Year

Equipment. Sutron 8210 data logger with cellular telemetry. Stage sensor is milltronics sonic probe and staff gage for reference. ISCO brand automatic sampler with 24-bottle capacity is housed in separate shelter and is triggered by stage sensor in the 8210 . Auxiliary shelter and sampler installed during gage construction upgrade. No provision for discharge measurements above wading stages.

Field Work. The station was visited sixteen times for the purpose of making a discharge measurement and/or servicing the instrumentation. Field inspections for the gage are listed under site history files on the Hydstra database. Discharge measurements for the gage are listed under site gauging files on the Hydstra database.

\section{Datum Correction. None.}

Gage-Height Record. The data logger referenced to the outside gage gave a complete and satisfactory record for the year; October 29 to December 2 when data logger malfunctioned.

Rating. Streambed is well armored with bedrock and boulders. Some pockets of sand exist from sediment deposition. Vegetation is sparse in the channel bottom and the banks. Scour should be minimal to nonexistent. The gage reach is straight for 400 feet upstream and 200 feet downstream.

No discharge measurements were made this year; sixteen inspections of no flow were made this water year. All inspections of no flow were used to develop a "V" diagram shift need to adjust for PZF.

Rating No. 1 was continued in use.

Discharge. Discharge was computed by applying gage height to Rating No. 1 through shift adjustment based on "V" diagrams. Discharge for period of missing gage height record was computed by comparison with E265 and analysis of precipitation records.

Remarks. Records fair, to good, except for estimated daily discharges, which are poor. 


\section{E263 Water at SR 4}

Daily Mean Discharge in Cubic Feet per Second

Water Year October 2005 to September 2006

\begin{tabular}{|c|c|c|c|c|c|c|c|c|c|c|c|c|}
\hline DAY & OCT & NOV & DEC & JAN & FEB & MAR & APR & MAY & JUN & JUL & AUG & SEP \\
\hline 1 & 0 & $0^{*}$ & $0^{*}$ & 0 & 0 & 0 & 0 & 0 & 0 & 0 & 0 & 1.1 \\
\hline 2 & 0 & $0^{*}$ & $0^{*}$ & 0 & 0 & 0 & 0 & 0 & 0 & 0 & 0 & .05 \\
\hline 3 & 0 & $0^{*}$ & 0 & 0 & 0 & 0 & 0 & 0 & 0 & 0 & 0 & 0 \\
\hline 4 & 0 & $0^{*}$ & 0 & 0 & 0 & 0 & 0 & 0 & 0 & 0 & 0 & 0 \\
\hline 5 & 0 & $0^{*}$ & 0 & 0 & 0 & 0 & 0 & 0 & 0 & 0 & 0 & 0 \\
\hline 6 & 0 & $0^{*}$ & 0 & 0 & 0 & 0 & 0 & 0 & 0 & 0 & 0 & 0 \\
\hline 7 & 0 & $0^{*}$ & 0 & 0 & 0 & 0 & 0 & 0 & 0 & 0 & 0 & 0 \\
\hline 8 & 0 & $0^{*}$ & 0 & 0 & 0 & 0 & 0 & 0 & 0 & 0 & 0 & 0 \\
\hline 9 & 0 & $0^{*}$ & 0 & 0 & 0 & 0 & 0 & 0 & 0 & 0 & 0 & 0 \\
\hline 10 & 0 & $0^{*}$ & 0 & 0 & 0 & 0 & 0 & 0 & 0 & 0 & 0 & 0 \\
\hline 11 & 0 & $0^{*}$ & 0 & 0 & 0 & 0 & 0 & 0 & 0 & 0 & 0 & 1.4 \\
\hline 12 & 0 & $0^{*}$ & 0 & 0 & 0 & 0 & 0 & 0 & 0 & 0 & 0 & .01 \\
\hline 13 & 0 & $0^{*}$ & 0 & 0 & 0 & 0 & 0 & 0 & 0 & 0 & 0 & 0 \\
\hline 14 & 0 & $0^{*}$ & 0 & 0 & 0 & 0 & 0 & 0 & 0 & 0 & .07 & 0 \\
\hline 15 & 0 & $0^{*}$ & 0 & 0 & 0 & 0 & 0 & 0 & 0 & 0 & .08 & 0 \\
\hline 16 & 0 & $0^{*}$ & 0 & 0 & 0 & 0 & 0 & 0 & 0 & 0 & 0 & 0 \\
\hline 17 & 0 & $0^{*}$ & 0 & 0 & 0 & 0 & 0 & 0 & 0 & 0 & 0 & 0 \\
\hline 18 & 0 & $0^{*}$ & 0 & 0 & 0 & 0 & 0 & 0 & 0 & 0 & 0 & 0 \\
\hline 19 & 0 & $0^{*}$ & 0 & 0 & 0 & 0 & 0 & 0 & 0 & 0 & .16 & 0 \\
\hline 20 & 0 & $0^{*}$ & 0 & 0 & 0 & 0 & 0 & 0 & 0 & 0 & .01 & 0 \\
\hline 21 & 0 & $0^{*}$ & 0 & 0 & 0 & 0 & 0 & 0 & 0 & 0 & .24 & 0 \\
\hline 22 & 0 & $0^{*}$ & 0 & 0 & 0 & 0 & 0 & 0 & 0 & 0 & 0 & 0 \\
\hline 23 & 0 & $0^{*}$ & 0 & 0 & 0 & 0 & 0 & 0 & 0 & 0 & 0 & 0 \\
\hline 24 & 0 & $0^{*}$ & 0 & 0 & 0 & 0 & 0 & 0 & 0 & 0 & 0 & 0 \\
\hline 25 & 0 & $0^{*}$ & 0 & 0 & 0 & 0 & 0 & 0 & 0 & 0 & 6.5 & 0 \\
\hline 26 & 0 & $0^{*}$ & 0 & 0 & 0 & 0 & 0 & 0 & 0 & 0 & .30 & 0 \\
\hline 27 & 0 & $0^{*}$ & 0 & 0 & 0 & 0 & 0 & 0 & 0 & 0 & 0 & 0 \\
\hline 28 & 0 & $0^{*}$ & 0 & 0 & 0 & 0 & 0 & 0 & 0 & 0 & 0 & 0 \\
\hline 29 & $0^{*}$ & $0^{*}$ & 0 & 0 & ------ & 0 & 0 & 0 & .94 & 0 & 0 & 0 \\
\hline 30 & $0^{*}$ & $0^{*}$ & 0 & 0 & ------ & 0 & 0 & 0 & 0 & 0 & .01 & 0 \\
\hline 31 & $0^{*}$ & --.-- & 0 & 0 & ----- & 0 & ----- & 0 & --.-- & 0 & 0 & ---- \\
\hline Total & 0 & 0 & 0 & 0 & 0 & 0 & 0 & 0 & 0.94 & 0 & 7.37 & 2.56 \\
\hline Mean & 0 & 0 & 0 & 0 & 0 & 0 & 0 & 0 & .031 & 0 & .24 & .085 \\
\hline Max & 0 & 0 & 0 & 0 & 0 & 0 & 0 & 0 & .94 & 0 & 6.5 & 1.4 \\
\hline Min & 0 & 0 & 0 & 0 & 0 & 0 & 0 & 0 & 0 & 0 & 0 & 0 \\
\hline Acre-Ft & 0 & 0 & 0 & 0 & 0 & 0 & 0 & 0 & 1.9 & 0 & 15 & 5.1 \\
\hline Wtr Year & 2006 & Total & 10.87 & Mean & .030 & & Max & 6.5 & Min & 0 & Acre-Ft & 22 \\
\hline Cal Year & 2005 & Total & 78.30 & Mean & .21 & & Max & 9.0 & Min & 0 & Acre-Ft & 155 \\
\hline
\end{tabular}

* Estimated 


\section{E265 Water below SR 4}

Location. Lat. 35 $48^{\prime} 18^{\prime \prime}$, long. 106 $14^{\prime} 31^{\prime \prime}$ in Ramon Vigil Grant, Los Alamos County, on left bank 0.4 mile downstream from SR 4, and 4.0 miles southwest of White Rock, New Mexico.

Drainage Area. $13.11 \mathrm{mi}^{2}$.

Period of Record. October 1993 through September 30, 2006.

Revised Records. LA-13905-PR: Drainage area (this report)

Gage. Data logger with cellular telemetry and stabilized natural rock control. Elevation of gage is 6,309 $\mathrm{ft}$ above NGVD from GIS 9.1.

Remarks. Water discharge records good, except for estimated daily discharges, which are poor.

Average Discharge. $12 \mathrm{yr}, 0.05 \mathrm{ft}^{3} / \mathrm{s}, 36$ acre-ft/yr.

Extremes for Period of Record. Maximum discharge $274 \mathrm{ft}^{3} / \mathrm{s}$, gage height $5.13 \mathrm{ft}$ (from flood mark), June 28, 2000. No flow most of time.

Extremes for Current Water Year. Maximum discharge $47 \mathrm{ft}^{3} / \mathrm{s}, 1430 \mathrm{~h}$, August 25, gage height $1.70 \mathrm{ft}$. No flow most of time.

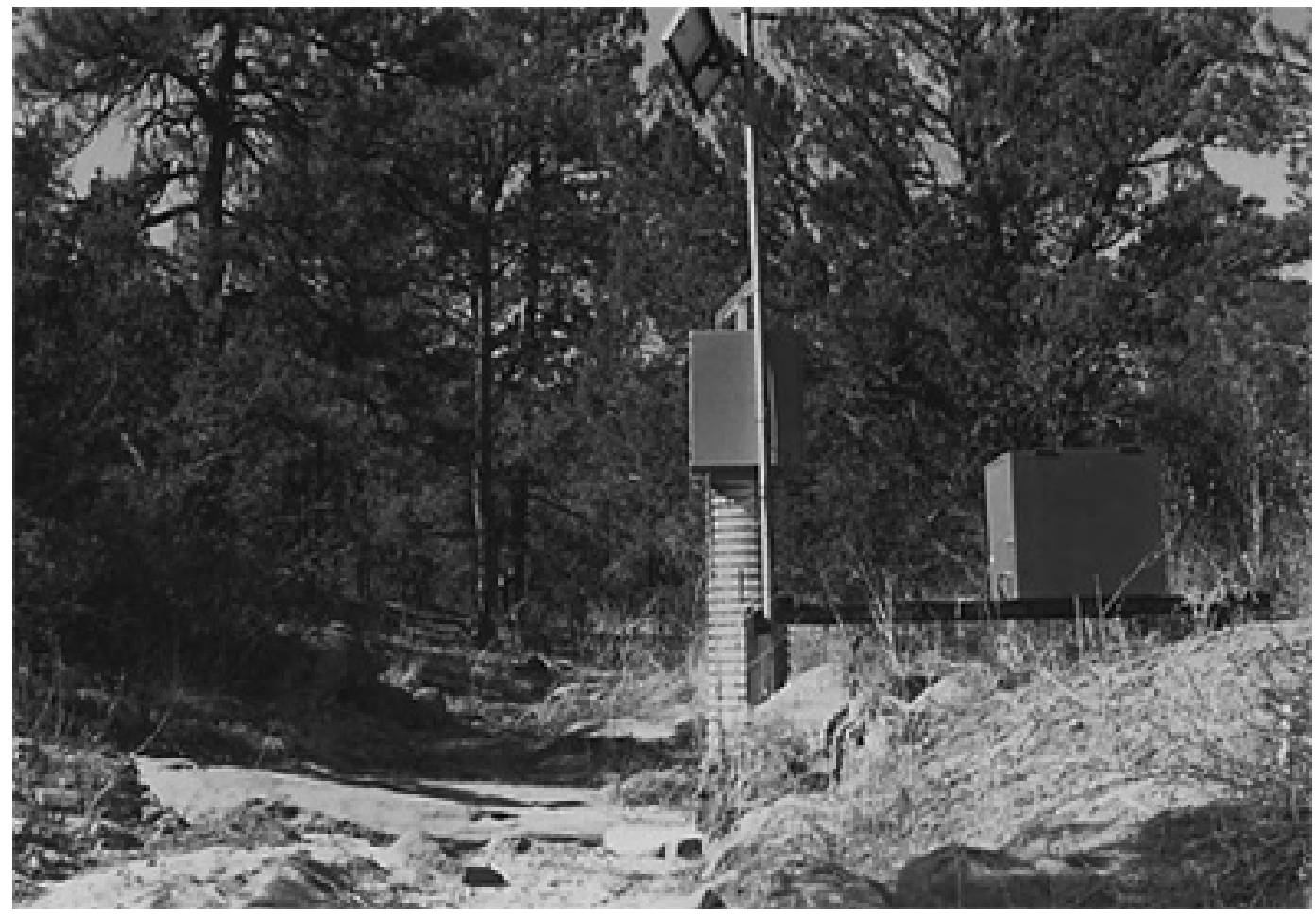




\section{E265 Water below SR 4 \\ Station Analysis \\ 2006 Water Year}

Equipment. Sutron 8210 data logger with cellular speech modem driven by quadrature encored and float tape. Outside staff is reference gage. Auxiliary shelter houses ISCO 3700 automatic sampler that is stage-activated by the data logger. No provisions for measurement above wading stage. All high-flow measurement will be by slope-area or critical-depth computation methods.

Field Work. the station was visited twelve times for the purpose of making a discharge measurement and/or servicing the instrumentation. Field inspections for the gage are listed under site history files on the Hydstra database. Discharge measurements for the gage are listed under site gauging files on the Hydstra database.

Datum Correction. Level run December 10, 1993, found gage within limits. No changes necessary.

Gage-Height Record. The data logger referenced to the outside gage gave a complete and satisfactory record for the year.

Rating. the channel is straight for 100 feet above and below gage. Banks are low and have very little vegetation. Streambed is mostly rock with lenses of sand.

Eleven inspections and one (No. 17) discharge measurements were made this water year.

Measurements defined shift for low point of "V" diagram. Middle and upper points are zero.

Rating No. 4 was used for the entire water year.

Discharge. Discharge was computed form Rating No. 4 using 1 variable shift curve that was defined by the measurement and listed on the work sheet. Records were compared with E263.

Remarks. Records fair. 


\section{E265 Water below SR 4}

Daily Mean Discharge in Cubic Feet per Second

Water Year October 2005 to September 2006

\begin{tabular}{|c|c|c|c|c|c|c|c|c|c|c|c|c|}
\hline DAY & OCT & NOV & DEC & JAN & FEB & MAR & APR & MAY & JUN & JUL & AUG & SEP \\
\hline 1 & 0 & 0 & 0 & 0 & 0 & 0 & 0 & 0 & 0 & 0 & 0 & .65 \\
\hline 2 & 0 & 0 & 0 & 0 & 0 & 0 & 0 & 0 & 0 & 0 & 0 & .20 \\
\hline 3 & 0 & 0 & 0 & 0 & 0 & 0 & 0 & 0 & 0 & 0 & 0 & 0 \\
\hline 4 & 0 & 0 & 0 & 0 & 0 & 0 & 0 & 0 & 0 & 0 & 0 & 0 \\
\hline 5 & 0 & 0 & 0 & 0 & 0 & 0 & 0 & 0 & 0 & 0 & 0 & 0 \\
\hline 6 & 0 & 0 & 0 & 0 & 0 & 0 & 0 & 0 & 0 & 0 & 0 & 0 \\
\hline 7 & 0 & 0 & 0 & 0 & 0 & 0 & 0 & 0 & 0 & 0 & 0 & 0 \\
\hline 8 & 0 & 0 & 0 & 0 & 0 & 0 & 0 & 0 & 0 & 0 & 0 & 0 \\
\hline 9 & 0 & 0 & 0 & 0 & 0 & 0 & 0 & 0 & 0 & 0 & 0 & 0 \\
\hline 10 & 0 & 0 & 0 & 0 & 0 & 0 & 0 & 0 & 0 & 0 & 0 & 0 \\
\hline 11 & 0 & 0 & 0 & 0 & 0 & 0 & 0 & 0 & 0 & 0 & 0 & .93 \\
\hline 12 & 0 & 0 & 0 & 0 & 0 & 0 & 0 & 0 & 0 & 0 & 0 & .15 \\
\hline 13 & 0 & 0 & 0 & 0 & 0 & 0 & 0 & 0 & 0 & 0 & 0 & 0 \\
\hline 14 & 0 & 0 & 0 & 0 & 0 & 0 & 0 & 0 & 0 & 0 & .07 & 0 \\
\hline 15 & 0 & 0 & 0 & 0 & 0 & 0 & 0 & 0 & 0 & 0 & .24 & 0 \\
\hline 16 & 0 & 0 & 0 & 0 & 0 & 0 & 0 & 0 & 0 & 0 & 0 & 0 \\
\hline 17 & 0 & 0 & 0 & 0 & 0 & 0 & 0 & 0 & 0 & 0 & 0 & 0 \\
\hline 18 & 0 & 0 & 0 & 0 & 0 & 0 & 0 & 0 & 0 & 0 & 0 & 0 \\
\hline 19 & 0 & 0 & 0 & 0 & 0 & 0 & 0 & 0 & 0 & 0 & .28 & 0 \\
\hline 20 & 0 & 0 & 0 & 0 & 0 & 0 & 0 & 0 & 0 & 0 & .01 & 0 \\
\hline 21 & 0 & 0 & 0 & 0 & 0 & 0 & 0 & 0 & 0 & 0 & .32 & 0 \\
\hline 22 & 0 & 0 & 0 & 0 & 0 & 0 & 0 & 0 & 0 & 0 & 0 & 0 \\
\hline 23 & 0 & 0 & 0 & 0 & 0 & 0 & 0 & 0 & 0 & 0 & 0 & 0 \\
\hline 24 & 0 & 0 & 0 & 0 & 0 & 0 & 0 & 0 & 0 & 0 & 0 & 0 \\
\hline 25 & 0 & 0 & 0 & 0 & 0 & 0 & 0 & 0 & 0 & 0 & 5.1 & 0 \\
\hline 26 & 0 & 0 & 0 & 0 & 0 & 0 & 0 & 0 & 0 & 0 & .50 & 0 \\
\hline 27 & 0 & 0 & 0 & 0 & 0 & 0 & 0 & 0 & 0 & 0 & .01 & 0 \\
\hline 28 & 0 & 0 & 0 & 0 & 0 & 0 & 0 & 0 & 0 & 0 & 0 & 0 \\
\hline 29 & 0 & 0 & 0 & 0 & ------ & 0 & 0 & 0 & .80 & 0 & 0 & 0 \\
\hline 30 & 0 & 0 & 0 & 0 & ----- & 0 & 0 & 0 & .03 & 0 & .06 & 0 \\
\hline 31 & 0 & ----- & 0 & 0 & ----- & 0 & ----- & 0 & ---- & 0 & .01 & ----- \\
\hline Total & 0 & 0 & 0 & 0 & 0 & 0 & 0 & 0 & 0.83 & 0 & 6.60 & 1.93 \\
\hline Mean & 0 & 0 & 0 & 0 & 0 & 0 & 0 & 0 & .028 & 0 & .21 & .064 \\
\hline Max & 0 & 0 & 0 & 0 & 0 & 0 & 0 & 0 & .80 & 0 & 5.1 & .93 \\
\hline Min & 0 & 0 & 0 & 0 & 0 & 0 & 0 & 0 & 0 & 0 & 0 & 0 \\
\hline Acre-Ft & 0 & 0 & 0 & 0 & 0 & 0 & 0 & 0 & 1.6 & 0 & 13 & 3.8 \\
\hline Wtr Year & 2006 & Total & 9.36 & Mear & .026 & & Max & 5.1 & Min & 0 & Acre-Ft & 19 \\
\hline Cal Year & 2005 & Total & 77.43 & Mear & .21 & & Max & 7.0 & Min & 0 & Acre-Ft & 154 \\
\hline
\end{tabular}




\section{E267 Potrillo above SR 4}

Location. Lat. $35^{\circ} 48^{\prime} 48^{\prime \prime}$, long. $106^{\circ} 14^{\prime} 00^{\prime \prime}$, in Ramon Vigil Grant, Los Alamos County, on left bank 0.25 mile upstream from NM SR 4 and 2.0 miles southwest of White Rock, Mew Mexico.

Drainage Area. $2.26 \mathrm{mi}^{2}$.

Period of Record. October 1993 to September 30, 2006.

Revised Records. LA-13551-PR (1998): Station number. Drainage Area (this report).

Gage. Data logger with cellular telemetry and concrete control. Elevation of gage is 6,454 $\mathrm{ft}$ above NGVD from GIS 9.1.

Remarks. Water discharge records good.

Average Discharge. $12 \mathrm{yr}, 0.004 \mathrm{ft}^{3} / \mathrm{s}, 2.9$ acre- $\mathrm{ft} / \mathrm{yr}$.

Extremes for Period of Record. Maximum discharge $63 \mathrm{ft}^{3} / \mathrm{s}$, August 29, 1995, gage height $2.70 \mathrm{ft}$ (from slope-area determination). No flow most of time.

Extremes for Current Water Year. Maximum discharge, $7.6 \mathrm{ft}^{3} / \mathrm{s}$, at $1440 \mathrm{~h}$, August 1, gage height $1.39 \mathrm{ft}$. No flow most of time.

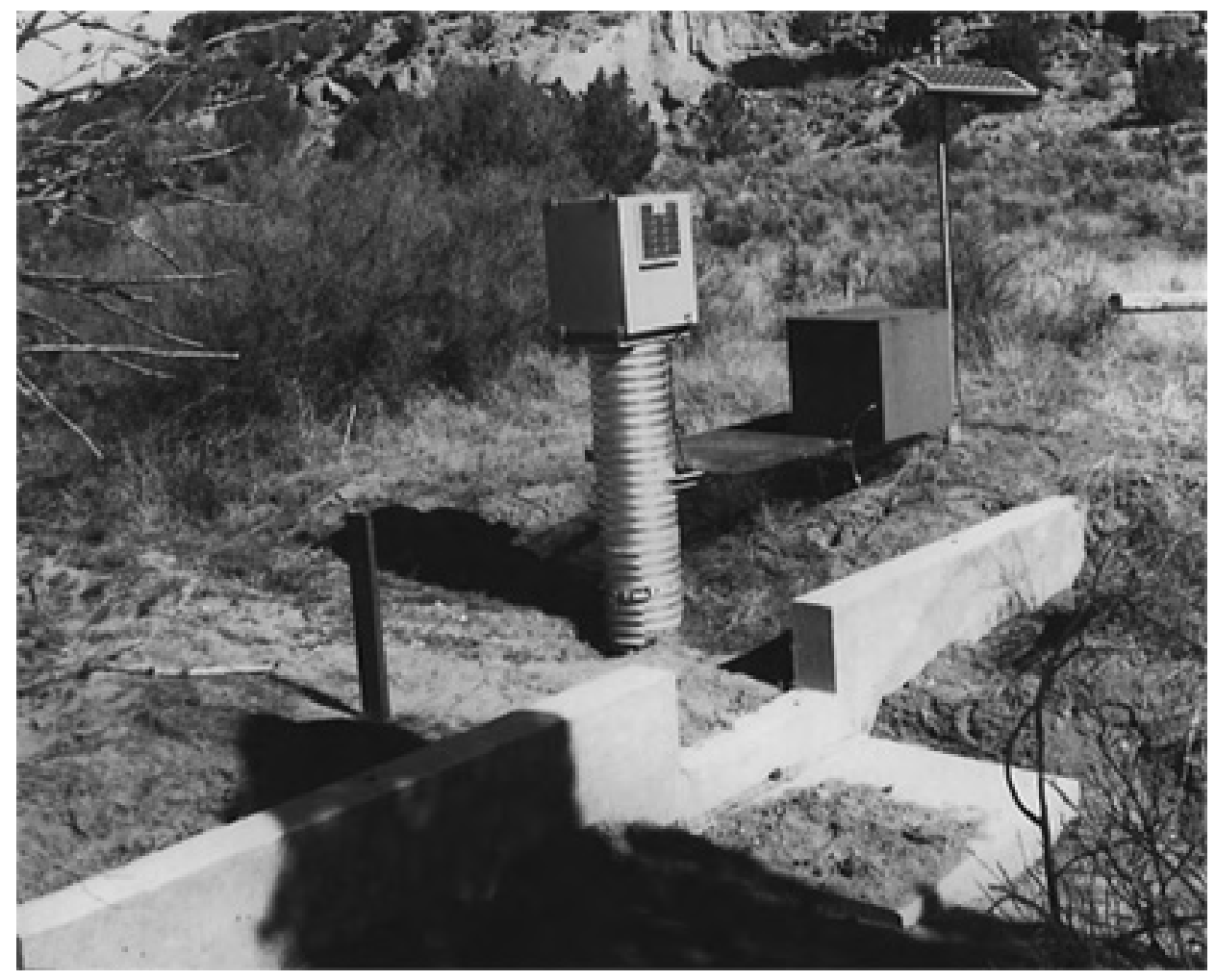




\section{E267 Portillo above SR 4 \\ Station Analysis \\ 2006 Water Year}

Equipment. Sutron model 8210 with cellular phone and speech modem. Logger is housed in $24 " \times 24 " \times 30$ " NEMA 4 enclosure on top of 18" CMP well. Sensor is float tape on Sutron quadrature encored. Outside staff is reference gage. ISCO model 3700 pump samplers are housed in separate shelters and are triggered by stage through the data logger.

Field Work. the station was visited thirteen times for the purpose of making a discharge measurement and/or servicing the instrumentation. Field inspections for the gage are listed under site history files on the Hydstra database. Discharge measurements for the gage are listed under site gauging files on the Hydstra database.

Datum Correction. Last levels run November 19, 1993, found staff gage reading within limits.

Gage-Height Record. the data logger referenced to the outside gage gave a complete and satisfactory record for the year except for May 9 to June 1 when data logger lost power.

Rating. The channel is sand and is fairly straight for 300 feet above gage and 150 feet below. Brush is fairly thick along stream bank but not below gage height of about 1.7 feet. The control is a concrete broad-crested weir.

Rating No. 1 was developed based on measurement 1-3 and PZF and theoretical computation using broad-crested weir. All measurements were made in 1995 water year.

Original shape and definition of rating was by computation using weir geometry with slope area used to define peak discharge and slope of upper end. Measurement 1-2 were made on recession and checked with rating rather well. They did shift some to the right but this was attributed to changing stage and sand movement from high flow. Shifts were applied by stage using last year's discharge measurement.

No discharge measurements were made during the analysis period. Thirteen visits of no flow were made this year. Rating No. 1 is considered good.

Discharge. Discharge was computed by applying gage height to Rating No. 1 through shift adjustment based on one shift diagram.

Remarks. Records good. 


\section{E267 Potrillo above SR 4}

Daily Mean Discharge in Cubic Feet per Second

Water Year October 2005 to September 2006

\begin{tabular}{|c|c|c|c|c|c|c|c|c|c|c|c|c|}
\hline DAY & OCT & NOV & DEC & JAN & FEB & MAR & APR & MAY & JUN & JUL & AUG & SEP \\
\hline 1 & 0 & 0 & 0 & 0 & 0 & 0 & 0 & 0 & $0^{*}$ & 0 & .08 & 0 \\
\hline 2 & 0 & 0 & 0 & 0 & 0 & 0 & 0 & 0 & 0 & 0 & 0 & 0 \\
\hline 3 & 0 & 0 & 0 & 0 & 0 & 0 & 0 & 0 & 0 & 0 & 0 & 0 \\
\hline 4 & 0 & 0 & 0 & 0 & 0 & 0 & 0 & 0 & 0 & 0 & 0 & 0 \\
\hline 5 & 0 & 0 & 0 & 0 & 0 & 0 & 0 & 0 & 0 & 0 & 0 & 0 \\
\hline 6 & 0 & 0 & 0 & 0 & 0 & 0 & 0 & 0 & 0 & 0 & .05 & 0 \\
\hline 7 & 0 & 0 & 0 & 0 & 0 & 0 & 0 & 0 & 0 & 0 & 0 & 0 \\
\hline 8 & 0 & 0 & 0 & 0 & 0 & 0 & 0 & 0 & 0 & 0 & 0 & 0 \\
\hline 9 & 0 & 0 & 0 & 0 & 0 & 0 & 0 & $0^{*}$ & 0 & 0 & 0 & 0 \\
\hline 10 & 0 & 0 & 0 & 0 & 0 & 0 & 0 & $0^{*}$ & 0 & 0 & 0 & 0 \\
\hline 11 & 0 & 0 & 0 & 0 & 0 & 0 & 0 & $0^{*}$ & 0 & 0 & 0 & 0 \\
\hline 12 & 0 & 0 & 0 & 0 & 0 & 0 & 0 & $0^{*}$ & 0 & 0 & 0 & 0 \\
\hline 13 & 0 & 0 & 0 & 0 & 0 & 0 & 0 & $0^{*}$ & 0 & 0 & 0 & 0 \\
\hline 14 & 0 & 0 & 0 & 0 & 0 & 0 & 0 & $0^{*}$ & 0 & 0 & 0 & 0 \\
\hline 15 & 0 & 0 & 0 & 0 & 0 & 0 & 0 & $0^{*}$ & 0 & 0 & 0 & 0 \\
\hline 16 & 0 & 0 & 0 & 0 & 0 & 0 & 0 & $0^{*}$ & 0 & 0 & 0 & 0 \\
\hline 17 & 0 & 0 & 0 & 0 & 0 & 0 & 0 & $0^{*}$ & 0 & 0 & 0 & 0 \\
\hline 18 & 0 & 0 & 0 & 0 & 0 & 0 & 0 & $0^{*}$ & 0 & 0 & 0 & 0 \\
\hline 19 & 0 & 0 & 0 & 0 & 0 & 0 & 0 & $0^{*}$ & 0 & 0 & .08 & 0 \\
\hline 20 & 0 & 0 & 0 & 0 & 0 & 0 & 0 & $0^{*}$ & 0 & 0 & .08 & 0 \\
\hline 21 & 0 & 0 & 0 & 0 & 0 & 0 & 0 & $0^{*}$ & 0 & 0 & 0 & 0 \\
\hline 22 & 0 & 0 & 0 & 0 & 0 & 0 & 0 & $0^{*}$ & 0 & 0 & 0 & 0 \\
\hline 23 & 0 & 0 & 0 & 0 & 0 & 0 & 0 & $0^{*}$ & 0 & 0 & 0 & 0 \\
\hline 24 & 0 & 0 & 0 & 0 & 0 & 0 & 0 & $0^{*}$ & 0 & 0 & 0 & 0 \\
\hline 25 & 0 & 0 & 0 & 0 & 0 & 0 & 0 & $0^{*}$ & 0 & 0 & 0 & 0 \\
\hline 26 & 0 & 0 & 0 & 0 & 0 & 0 & 0 & $0^{*}$ & 0 & 0 & 0 & 0 \\
\hline 27 & 0 & 0 & 0 & 0 & 0 & 0 & 0 & $0^{*}$ & 0 & 0 & 0 & 0 \\
\hline 28 & 0 & 0 & 0 & 0 & 0 & 0 & 0 & $0^{*}$ & 0 & 0 & 0 & 0 \\
\hline 29 & 0 & 0 & 0 & 0 & ----- & 0 & 0 & $0^{*}$ & 0 & 0 & 0 & 0 \\
\hline 30 & 0 & 0 & 0 & 0 & ---- & 0 & 0 & $0^{*}$ & 0 & 0 & 0 & 0 \\
\hline 31 & 0 & ----- & 0 & 0 & ---- & 0 & --- & $0^{*}$ & --- & 0 & 0 & ---- \\
\hline Total & 0 & 0 & 0 & 0 & 0 & 0 & 0 & 0 & 0 & 0 & 0.29 & 0 \\
\hline Mean & 0 & 0 & 0 & 0 & 0 & 0 & 0 & 0 & 0 & 0 & .009 & 0 \\
\hline Max & 0 & 0 & 0 & 0 & 0 & 0 & 0 & 0 & 0 & 0 & .08 & 0 \\
\hline Min & 0 & 0 & 0 & 0 & 0 & 0 & 0 & 0 & 0 & 0 & 0 & 0 \\
\hline Acre-Ft & 0 & 0 & 0 & 0 & 0 & 0 & 0 & 0 & 0 & 0 & .58 & 0 \\
\hline Wtr Year & 2006 & Total & 0.29 & Mean & .00 & & $\operatorname{Max}$ & 08 & Min & 0 & Acre-Ft & .58 \\
\hline Cal Year & 2005 & Total & 0.11 & Mean & 0 & & Max & 11 & Min & 0 & Acre-Ft & .22 \\
\hline
\end{tabular}




\section{E275 Ancho below SR 4}

Location. Lat. 3546'54", long. 106 $14^{\prime} 42^{\prime \prime}$, in Ramon Vigil Grant, Los Alamos County, 0.3 mile downstream from SR 4, and 5.5 miles southwest of White Rock, New Mexico.

Drainage Area. $4.75 \mathrm{mi}^{2}$.

Period of Record. December 1993 to September 30, 2006.

Revised Record. Drainage Area (this report).

Gage. Data logger with cellular telemetry and concrete stabilized natural control. Elevation of gage is $6,190 \mathrm{ft}$ above NGVD from GIS 9.1.

Remarks. Water discharge records good.

Average Discharge. $11 \mathrm{yr}, 0.012 \mathrm{ft}^{3} / \mathrm{s}, 8.7$ acre- $\mathrm{ft} / \mathrm{yr}$.

Extremes for Period of Record. Maximum discharge $534 \mathrm{ft}^{3} / \mathrm{s}$, gage height $2.74 \mathrm{ft}$, May 26, 2003. No flow most of time.

Extremes for Current Water Year. Maximum discharge $325 \mathrm{ft}^{3} / \mathrm{s}$ at $1525 \mathrm{~h}$, August 19 gage height $2.30 \mathrm{ft}$. No flow most of time.

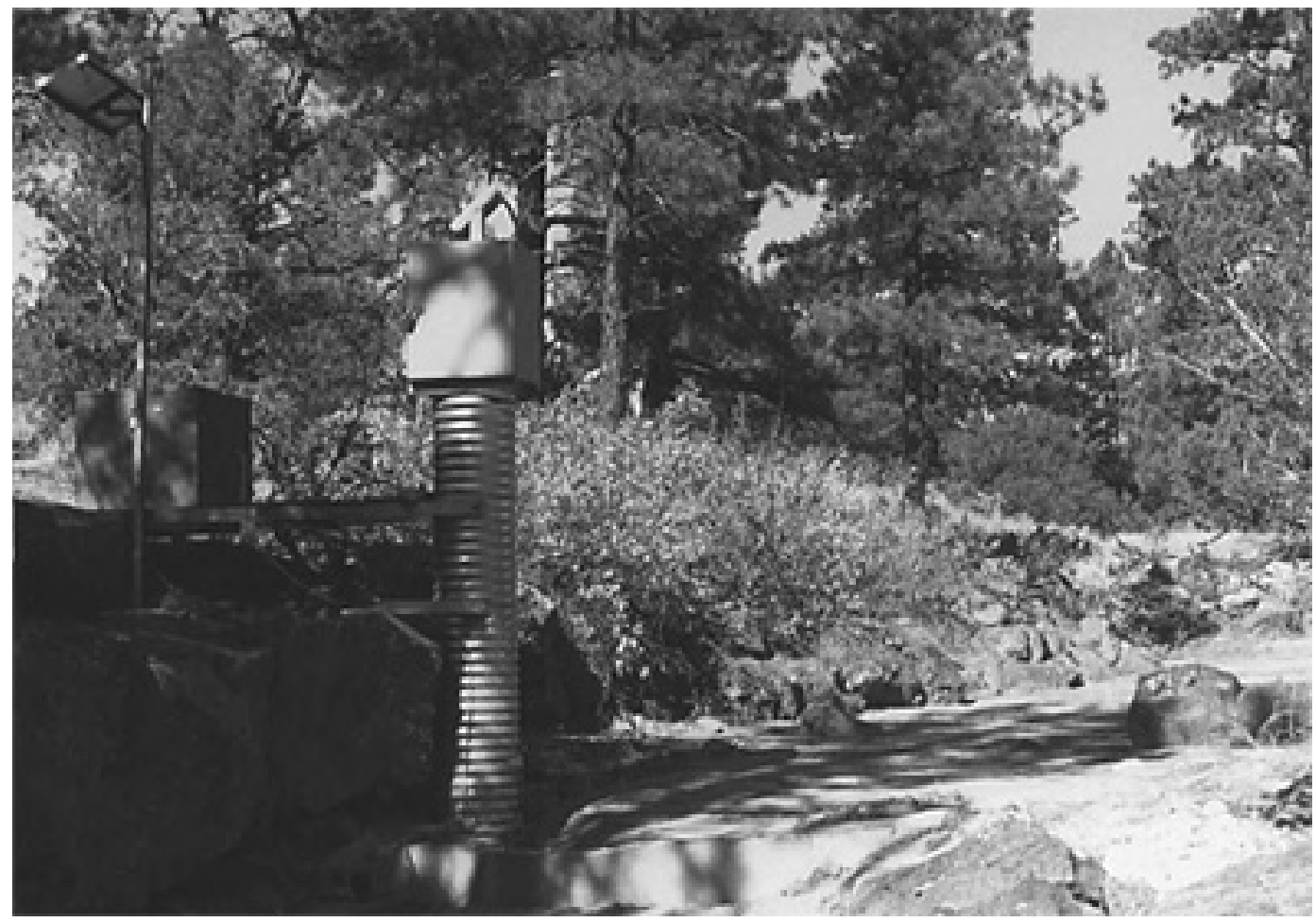




\section{E275 Ancho Below SR 4 \\ Station Analysis \\ 2006 Water Year}

Equipment. Sutron 8210 data logger with cellular speech modem driven by float tape on quadrature encorder. Outside staff is available for reference. Auxiliary shelters house ISCO 3700 automatic samplers that are stage activated by the data logger. No provision for measurements above wading stage.

Field Work. The station was visited nine times for the purpose of making a discharge measurement and/or servicing the instrumentation. Field inspections for the gage are listed under site history files on the Hydstra database. Discharge measurements for the gage are listed under site gauging files on the Hydstra database.

Datum Correction. None from levels.

Gage-Height Record. The data logger referenced to the outside gage gave a complete and satisfactory record for the year.

Rating. Streambed is series of outcrops and sand pockets with much sand movement on flow events. High water channel is straight for 200 feet upstream. Flow below gage goes into super critical flow as fall increases radically below station. One-fourth mile upstream channel has very low banks and may spread out to large widths. It contracts markedly from there to the gage. The control is natural rock outcrop stabilized by concrete.

Rating No. 1 was developed from PZF and measurement 1, 2 on recession of event in 1995 and No. 3, which is a slope area measurement made on the event in 1996. Rating No. 1 was extended from 1.85 to 2.75 feet from logarithmic plotting.

No discharge measurements were made. Nine inspections of no flow were made this year. Rating No. 1 continued in use through the water year.

Discharge. Computed from Rating No. 1 using variable diagram (-.10 at lower end). Period of lost record was all zero flow from comparison with E273 and E274.

Remarks. Records good. 


\section{E275 Ancho below SR 4}

Daily Mean Discharge in Cubic Feet per Second

Water Year October 2005 to September 2006

\begin{tabular}{|c|c|c|c|c|c|c|c|c|c|c|c|c|}
\hline DAY & OCT & NOV & DEC & JAN & FEB & MAR & APR & MAY & JUN & JUL & AUG & SEP \\
\hline 1 & 0 & 0 & 0 & 0 & 0 & 0 & 0 & 0 & 0 & 0 & 0 & 0 \\
\hline 2 & 0 & 0 & 0 & 0 & 0 & 0 & 0 & 0 & 0 & 0 & 0 & 0 \\
\hline 3 & 0 & 0 & 0 & 0 & 0 & 0 & 0 & 0 & 0 & 0 & 0 & 0 \\
\hline 4 & 0 & 0 & 0 & 0 & 0 & 0 & 0 & 0 & 0 & 0 & 0 & 0 \\
\hline 5 & 0 & 0 & 0 & 0 & 0 & 0 & 0 & 0 & 0 & 1.2 & 0 & 0 \\
\hline 6 & 0 & 0 & 0 & 0 & 0 & 0 & 0 & 0 & 0 & .01 & 0 & 0 \\
\hline 7 & 0 & 0 & 0 & 0 & 0 & 0 & 0 & 0 & 0 & 0 & 0 & 0 \\
\hline 8 & 0 & 0 & 0 & 0 & 0 & 0 & 0 & 0 & 0 & 0 & 0 & 0 \\
\hline 9 & .06 & 0 & 0 & 0 & 0 & 0 & 0 & 0 & 0 & 0 & 0 & 0 \\
\hline 10 & 0 & 0 & 0 & 0 & 0 & 0 & 0 & 0 & 0 & 0 & 0 & 0 \\
\hline 11 & 0 & 0 & 0 & 0 & 0 & 0 & 0 & 0 & 0 & 0 & 0 & 0 \\
\hline 12 & 0 & 0 & 0 & 0 & 0 & 0 & 0 & 0 & 0 & 0 & 0 & 0 \\
\hline 13 & 0 & 0 & 0 & 0 & 0 & 0 & 0 & 0 & 0 & 0 & .70 & 0 \\
\hline 14 & 0 & 0 & 0 & 0 & 0 & 0 & 0 & 0 & 0 & 0 & .10 & 0 \\
\hline 15 & 0 & 0 & 0 & 0 & 0 & 0 & 0 & 0 & 0 & 0 & .10 & 0 \\
\hline 16 & 0 & 0 & 0 & 0 & 0 & 0 & 0 & 0 & 0 & 0 & 0 & 0 \\
\hline 17 & 0 & 0 & 0 & 0 & 0 & 0 & 0 & 0 & 0 & 0 & 0 & 0 \\
\hline 18 & 0 & 0 & 0 & 0 & 0 & 0 & 0 & 0 & 0 & 0 & 0 & 0 \\
\hline 19 & 0 & 0 & 0 & 0 & 0 & 0 & 0 & 0 & 0 & 0 & 8.8 & 0 \\
\hline 20 & 0 & 0 & 0 & 0 & 0 & 0 & 0 & 0 & 0 & 0 & .15 & 0 \\
\hline 21 & 0 & 0 & 0 & 0 & 0 & 0 & 0 & 0 & 0 & 0 & .14 & 0 \\
\hline 22 & 0 & 0 & 0 & 0 & 0 & 0 & 0 & 0 & .36 & 0 & .06 & 0 \\
\hline 23 & 0 & 0 & 0 & 0 & 0 & 0 & 0 & 0 & 0 & 0 & 0 & 0 \\
\hline 24 & 0 & 0 & 0 & 0 & 0 & 0 & 0 & 0 & 0 & 0 & 0 & 0 \\
\hline 25 & 0 & 0 & 0 & 0 & 0 & 0 & 0 & 0 & 0 & 0 & 0 & 0 \\
\hline 26 & 0 & 0 & 0 & 0 & 0 & 0 & 0 & 0 & 0 & 0 & 0 & 0 \\
\hline 27 & 0 & 0 & 0 & 0 & 0 & 0 & 0 & 0 & 0 & 0 & 0 & 0 \\
\hline 28 & 0 & 0 & 0 & 0 & 0 & 0 & 0 & 0 & 0 & 0 & 0 & 0 \\
\hline 29 & 0 & 0 & 0 & 0 & ------ & 0 & 0 & 0 & 0 & 0 & 0 & 0 \\
\hline 30 & 0 & 0 & 0 & 0 & ------ & 0 & 0 & 0 & 0 & 0 & 0 & 0 \\
\hline 31 & 0 & ------ & 0 & 0 & ----- & 0 & ----- & 0 & ----- & 0 & 0 & -... \\
\hline Total & 0.06 & 0 & 0 & 0 & 0 & 0 & 0 & 0 & 0.36 & 1.21 & 10.05 & 0 \\
\hline Mean & .002 & 0 & 0 & 0 & 0 & 0 & 0 & 0 & .012 & .039 & .32 & 0 \\
\hline Max & .06 & 0 & 0 & 0 & 0 & 0 & 0 & 0 & .36 & 1.2 & 8.8 & 0 \\
\hline Min & 0 & 0 & 0 & 0 & 0 & 0 & 0 & 0 & 0 & 0 & 0 & 0 \\
\hline Acre-Ft & .12 & 0 & 0 & 0 & 0 & 0 & 0 & 0 & .71 & 2.4 & 20 & 0 \\
\hline Wtr Year & 2006 & Total & 11.68 & Mean & .032 & & $\operatorname{Max}$ & & Min & 0 & Acre-Ft & 23 \\
\hline Cal Year & 2005 & Total & 0.61 & Mean & .002 & & Max & 9 & Min & 0 & Acre-Ft & 1.2 \\
\hline
\end{tabular}




\section{E350 Rio de los Frijoles at Bandelier}

Location. Lat. 3546'37", long. 106¹6'09", Ramon Vigil Grant, Sandoval County, in Bandelier National Monument, on right bank $800 \mathrm{ft}$ downstream from Monument Headquarters, 6.5 miles south of Los Alamos, 18.5 miles northwest of Santa Fe, and at river mile 2.0.

Drainage Area. $18.35 \mathrm{mi}^{2}$.

Period of Record. July 1963 to September 1969; July 1977 to September 1982; May 1993 to September 1996; and October 1998 to September 30, 2006.

Revised Record. Drainage Area (this report)

Gage. Data logger and concrete control. Elevation of gage is 6,039 ft above NGVD from GIS 9.1.

Remarks. Water-discharge records good, except those for winter period, which are poor. One small diversion from left bank about 1.0 mile upstream for irrigation of small orchard. The La Mesa fire, which occurred during mid-June 1977, burned about $40 \%$ of the forest cover of this watershed.

Average Discharge. 8 yr (1999-2006) $1.1 \mathrm{ft}^{3} / \mathrm{s}, 797 \mathrm{acre}-\mathrm{ft} / \mathrm{yr}$.

Extremes for Period of Record. Maximum discharge 3,030 $\mathrm{ft}^{3} / \mathrm{s}$, July 21, 1978, gage height $6.34 \mathrm{ft}$, site and datum then in use. Minimum daily discharge $0 \mathrm{ft} / \mathrm{s}$, July 16-19 and 26, 2003.

Extremes for Current Water Year. Maximum discharge $90 \mathrm{ft}^{3} / \mathrm{s}$ at $1915 \mathrm{hr}$., July 29, gage height $3.21 \mathrm{ft}$. Minimum daily $0.08 \mathrm{ft}^{3} / \mathrm{s}$, June 21.

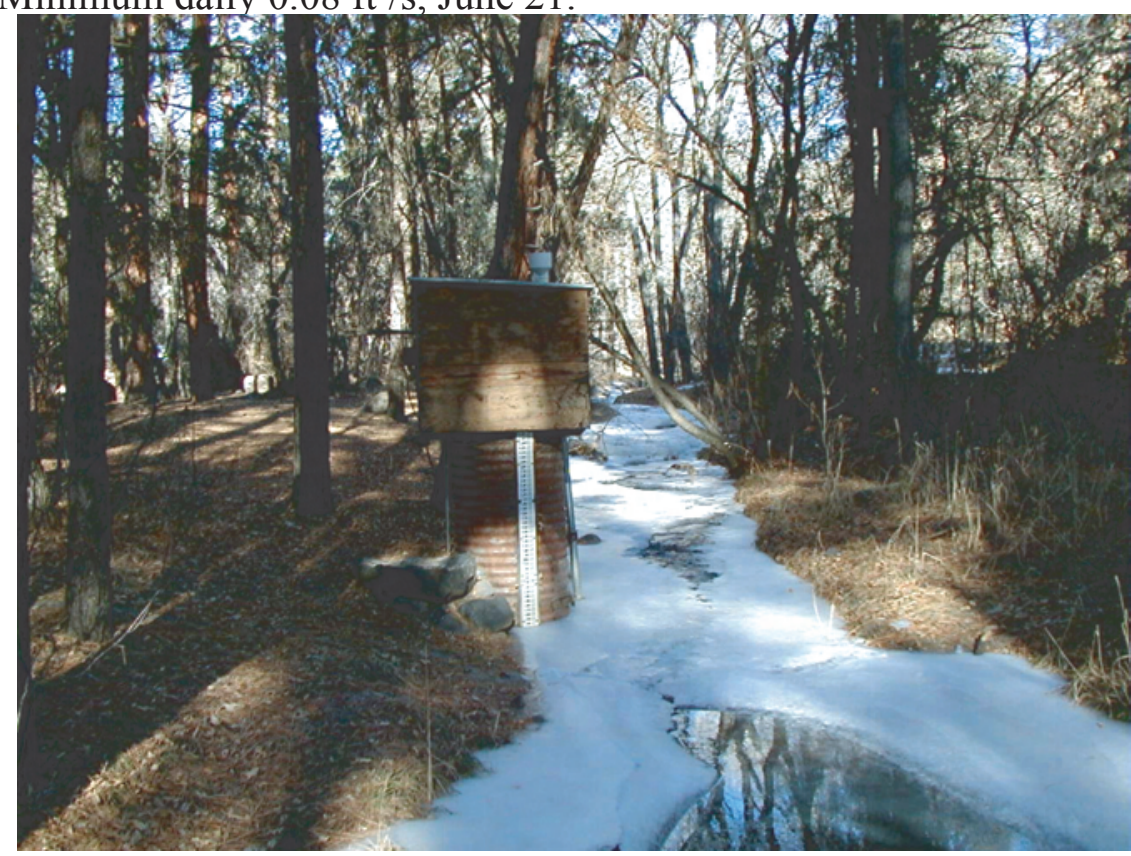




\section{E350 Rio de los Frijoles at Bandalier \\ Station Analysis \\ 2006 Water Year}

Equipment. Sutron 8200 data logger (5-min. scan interval) with quadrature encoder housed in a 4' $\times$ 4' metal shelter over a 24" CMP stilling well on right bank. An outside staff and float gage are available for reference. Station is equipped with 110 volt AC. Wading measurements are made 30-40 feet upstream from gage. High-flow measurement can be made up from bridge upstream from gage 200 feet above gage.

Field Work. The station was visited Twenty-six times for the purpose of making a discharge measurement and/or servicing the instrumentation. Field inspections for the gage are listed under site history files on the Hydstra database. Discharge measurements for the gage are listed under site gauging files on the Hydstra database.

Datum Correction. None from levels.

Gage-Height Record. The data logger referenced to the outside gage gave a complete and satisfactory record for the year, except for the following periods: December 3-13 and August 21-September 30, when float tape was moved and January 5 to February 25 when gage height was affected by ice.

Rating. The channel is about 10 feet wide and straight for about 150 feet upstream and downstream of gage. Low water control is a concrete-tapered notch with low point on right bank. The channel bed through this reach is composed of gravel and cobbles and should be stable. Vegetation is grasses and fairly sparse.

Eight discharge measurements (No. 160-167) and visits were made during the year.

Rating No. 3 was used through the year. The shifts were distributed based on time. Rating No. 3 is considered good.

Discharge. Discharge was computed by applying gage height to Rating No. 3 through a "V" shift. Records estimated due to gage height were based on field notes and weather record.

Remarks. Records good, except for estimated daily discharges, which are poor. 


\section{E350 Rio de los Frijoles at Bandelier}

Daily Mean Discharge in Cubic Feet per Second

Water Year October 2005 to September 2006

\begin{tabular}{|c|c|c|c|c|c|c|c|c|c|c|c|c|}
\hline DAY & OCT & NOV & DEC & JAN & FEB & MAR & APR & MAY & JUN & JUL & AUG & SEP \\
\hline 1 & 1.5 & 1.1 & 1.1 & .85 & $.91^{*}$ & .83 & .95 & .68 & .65 & 7.3 & 8.5 & $.87^{*}$ \\
\hline 2 & 1.2 & 1.1 & 1.1 & .82 & $.91^{*}$ & .80 & .95 & .64 & .66 & 7.0 & 8.3 & $1.2^{*}$ \\
\hline 3 & 1.1 & 1.1 & $1.1^{*}$ & .81 & $.89^{*}$ & .80 & .89 & .62 & .68 & 6.9 & 7.9 & $1.2^{*}$ \\
\hline 4 & 1.1 & 1.1 & $.94^{*}$ & .80 & $.88^{*}$ & .80 & .89 & .60 & .59 & 9.6 & 8.5 & $1.1^{*}$ \\
\hline 5 & 1.0 & 1.0 & $1.0^{*}$ & $.81^{*}$ & $.87^{*}$ & .80 & .92 & .63 & .55 & 18 & 14 & $1.1^{*}$ \\
\hline 6 & 1.2 & 1.1 & $1.1^{*}$ & .88 & $.81^{*}$ & .79 & .98 & .70 & .55 & 11 & 12 & $1.2^{*}$ \\
\hline 7 & 1.1 & 1.1 & $1.0^{*}$ & .91 & $.84^{*}$ & .78 & .95 & .63 & .62 & 11 & 14 & $1.6^{*}$ \\
\hline 8 & 1.0 & 1.1 & $1.0^{*}$ & .91 & $.88^{*}$ & .78 & .91 & .59 & .67 & 11 & 14 & $1.7^{*}$ \\
\hline 9 & 1.3 & 1.0 & $1.0^{*}$ & .88 & $.90^{*}$ & .82 & .88 & .57 & .54 & 13 & 14 & $1.4^{*}$ \\
\hline 10 & 1.3 & .99 & $1.0^{*}$ & .75 & $.89^{*}$ & .82 & .86 & .57 & .33 & 12 & 15 & $1.3^{*}$ \\
\hline 11 & 1.2 & 1.0 & $.99^{*}$ & .90 & $.80^{*}$ & .83 & .87 & .55 & .25 & 10 & 15 & $1.3^{*}$ \\
\hline 12 & 1.1 & 1.0 & $.98^{*}$ & .93 & $.80^{*}$ & .86 & .85 & .54 & .21 & 9.8 & 14 & $1.3^{*}$ \\
\hline 13 & 1.0 & 1.0 & $1.1^{*}$ & .99 & $.83^{*}$ & .80 & .84 & .52 & .19 & 9.4 & 18 & $1.2^{*}$ \\
\hline 14 & .94 & 1.0 & 1.1 & 1.0 & $.88^{*}$ & .89 & .83 & .54 & .17 & 9.2 & 9.8 & $1.1^{*}$ \\
\hline 15 & 1.1 & .96 & .93 & .98 & $.87^{*}$ & .96 & .82 & .62 & .17 & 9.2 & 3.1 & $1.1^{*}$ \\
\hline 16 & 1.3 & .98 & .95 & 1.0 & $.87^{*}$ & .90 & .83 & .59 & .17 & 9.0 & 2.6 & $1.1^{*}$ \\
\hline 17 & 1.1 & 1.0 & .82 & .88 & $.84^{*}$ & .88 & .81 & .57 & .17 & 8.8 & 1.8 & $.98^{*}$ \\
\hline 18 & 1.1 & 1.0 & .91 & 1.1 & $.87^{*}$ & .88 & .81 & .58 & .15 & 8.8 & 1.5 & $.97^{*}$ \\
\hline 19 & 1.2 & 1.0 & .99 & 1.1 & $.90^{*}$ & .88 & .83 & .53 & .12 & 9.0 & 2.8 & $.94^{*}$ \\
\hline 20 & 1.1 & 1.1 & .93 & 1.0 & $.88^{*}$ & .90 & .75 & .49 & .10 & 8.3 & 1.0 & $.99^{*}$ \\
\hline 21 & 1.1 & 1.1 & .88 & .98 & $.87^{*}$ & .90 & .79 & .46 & .08 & 8.1 & $1.0^{*}$ & $1.0^{*}$ \\
\hline 22 & 1.1 & 1.1 & .84 & .93 & $.88^{*}$ & .97 & .77 & .46 & .17 & 8.5 & $1.0^{*}$ & $.99^{*}$ \\
\hline 23 & 1.1 & 1.0 & .83 & .89 & $.92^{*}$ & .96 & .74 & .48 & .20 & 8.4 & $.95^{*}$ & $1.0^{*}$ \\
\hline 24 & 1.1 & .99 & .80 & .92 & $.89^{*}$ & .95 & .70 & .45 & .18 & 8.2 & $.92^{*}$ & $.93^{*}$ \\
\hline 25 & 1.1 & .99 & .78 & 1.1 & $.85^{*}$ & .93 & .71 & .45 & .16 & 7.8 & $.93^{*}$ & $.89^{*}$ \\
\hline 26 & 1.1 & 1.0 & .81 & 1.1 & .80 & .90 & .64 & .43 & .27 & 6.7 & $1.0^{*}$ & $.83^{*}$ \\
\hline 27 & 1.1 & 1.0 & .81 & .97 & .84 & .89 & .62 & .43 & .38 & 7.6 & $.84^{*}$ & $.79^{\star}$ \\
\hline 28 & 1.1 & .70 & .81 & .93 & .84 & 1.0 & .66 & .45 & .33 & 7.9 & $.74^{*}$ & $.77^{*}$ \\
\hline 29 & 1.1 & .59 & .83 & 1.0 & ------ & .95 & .78 & .45 & 9.3 & 8.9 & $.71^{*}$ & $.76^{*}$ \\
\hline 30 & 1.1 & .86 & .83 & .98 & ------ & .93 & .71 & .47 & 10 & 8.4 & $.71^{*}$ & $.70^{*}$ \\
\hline 31 & 1.1 & ------ & .82 & $.92^{*}$ & & ------ & ------- & .51 & ------ & 8.2 & $.68^{*}$ & ------ \\
\hline Total & 35.04 & 30.06 & 29.08 & 29.02 & & 24.21 & 24.54 & 16.80 & 28.61 & 287.0 & 195.28 & 32.31 \\
\hline Mean & 1.13 & 1.00 & .94 & .94 & .86 & .87 & .82 & .54 & .95 & 9.26 & 6.30 & 1.08 \\
\hline Max & 1.5 & 1.1 & 1.1 & 1.1 & .92 & 1.0 & .98 & .70 & 10 & 18 & 18 & 1.7 \\
\hline Min & .94 & .59 & .78 & .75 & .80 & .78 & .62 & .43 & .08 & 6.7 & .68 & .70 \\
\hline Acre-Ft & 70 & 60 & 58 & 58 & 48 & 54 & 49 & 33 & 57 & 569 & 387 & 64 \\
\hline Wtr Year & 2006 & Total & 759.06 & $\mathrm{Me}$ & 2.08 & & Max & 18 & Min & .08 & Acre-Ft & 1510 \\
\hline Cal Year & 2005 & Total & 726.64 & $\mathrm{Me}$ & $1.9 s$ & & Max & 25 & Min & .13 & Acre-Ft & 1440 \\
\hline
\end{tabular}





\section{Spring Stations}





\section{S001 SWSC Line Spring at TA-16}

Location. Lat. 35 51'1", long. 106 $20^{\circ} 23^{\prime \prime}, 30 \mathrm{ft}$ upstream from the SWSC line crossing of Cañon de Valle in Laboratory TA-16.

Gage. Data logger with $90^{\circ}$ weir. Elevation of gage is $7,437.0 \mathrm{ft}$ above NGVD from survey.

Period of Record. October 1, 1996, to September 30, 2006.

Remarks. Water discharge records good. This spring is in the Cañon de Valle drainage.

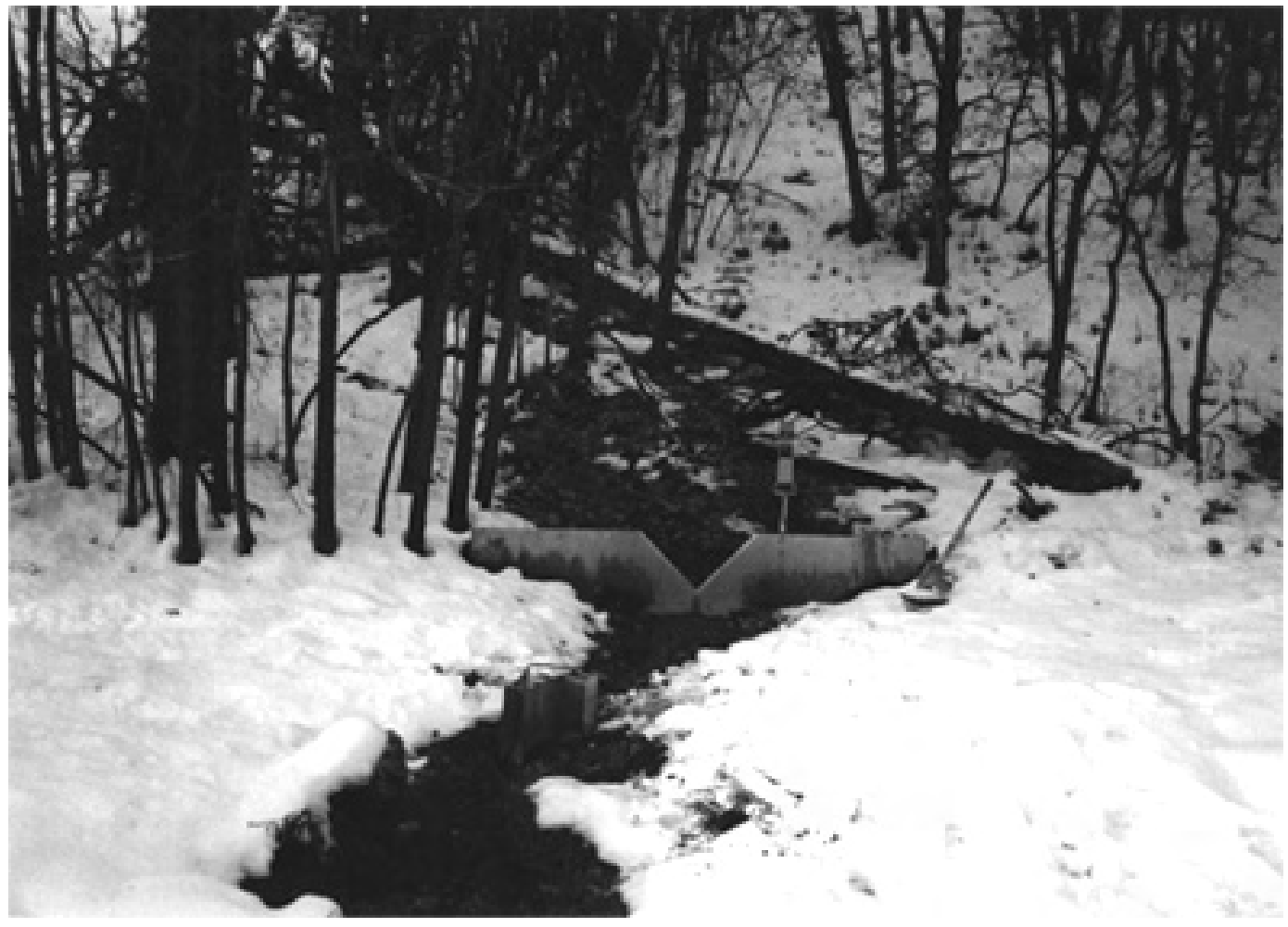




\section{S001 SWCS Line Spring at TA-16}

Daily Mean Discharge in Cubic Feet per Second

Water Year October 2005 to September 2006

\begin{tabular}{|c|c|c|c|c|c|c|c|c|c|c|c|c|}
\hline DAY & OCT & NOV & DEC & JAN & FEB & MAR & APR & MAY & JUN & JUL & AUG & SEP \\
\hline 1 & .001 & .002 & 0 & 0 & 0 & 0 & 0 & 0 & $0^{*}$ & 0 & 0 & 0 \\
\hline 2 & .001 & .002 & 0 & 0 & 0 & 0 & 0 & 0 & $0^{*}$ & 0 & 0 & 0 \\
\hline 3 & .001 & .002 & 0 & 0 & 0 & 0 & 0 & 0 & $0^{*}$ & 0 & 0 & 0 \\
\hline 4 & .001 & .001 & 0 & 0 & 0 & 0 & 0 & 0 & $0^{*}$ & 0 & 0 & 0 \\
\hline 5 & .001 & .001 & 0 & 0 & 0 & 0 & 0 & 0 & $0^{*}$ & 0 & 0 & 0 \\
\hline 6 & .001 & .001 & 0 & 0 & 0 & 0 & 0 & 0 & $0^{*}$ & 0 & 0 & 0 \\
\hline 7 & .001 & .001 & 0 & 0 & 0 & 0 & 0 & 0 & $0^{*}$ & 0 & 0 & 0 \\
\hline 8 & .002 & .001 & 0 & 0 & 0 & 0 & 0 & 0 & $0^{*}$ & 0 & 0 & 0 \\
\hline 9 & .002 & .001 & 0 & 0 & 0 & 0 & 0 & $0^{*}$ & $0^{*}$ & 0 & 0 & 0 \\
\hline 10 & .002 & 0 & 0 & 0 & 0 & 0 & 0 & $0^{*}$ & $0^{*}$ & 0 & 0 & 0 \\
\hline 11 & .002 & 0 & 0 & 0 & 0 & 0 & 0 & $0^{*}$ & $0^{*}$ & 0 & 0 & 0 \\
\hline 12 & .001 & 0 & 0 & 0 & 0 & 0 & 0 & $0^{*}$ & $0^{*}$ & 0 & 0 & 0 \\
\hline 13 & .001 & 0 & 0 & 0 & 0 & 0 & 0 & $0^{*}$ & $0^{*}$ & 0 & 0 & 0 \\
\hline 14 & .001 & 0 & 0 & 0 & 0 & 0 & 0 & $0^{*}$ & $0^{*}$ & 0 & 0 & 0 \\
\hline 15 & .001 & 0 & 0 & 0 & 0 & 0 & 0 & $0^{*}$ & $0^{*}$ & 0 & 0 & 0 \\
\hline 16 & 0 & 0 & 0 & 0 & 0 & 0 & 0 & $0^{*}$ & $0^{*}$ & 0 & 0 & 0 \\
\hline 17 & 0 & 0 & 0 & 0 & 0 & 0 & 0 & $0^{*}$ & $0^{*}$ & 0 & 0 & 0 \\
\hline 18 & .001 & 0 & 0 & 0 & 0 & 0 & 0 & $0^{*}$ & $0^{*}$ & 0 & 0 & 0 \\
\hline 19 & .001 & 0 & 0 & 0 & 0 & 0 & 0 & $0^{*}$ & 0 & 0 & 0 & 0 \\
\hline 20 & .001 & 0 & 0 & 0 & 0 & 0 & 0 & $0^{*}$ & 0 & 0 & 0 & 0 \\
\hline 21 & .001 & 0 & 0 & 0 & 0 & 0 & 0 & $0^{*}$ & 0 & 0 & 0 & 0 \\
\hline 22 & .001 & 0 & 0 & 0 & 0 & 0 & 0 & $0^{*}$ & 0 & 0 & 0 & 0 \\
\hline 23 & .001 & 0 & 0 & 0 & 0 & 0 & 0 & $0^{*}$ & 0 & 0 & 0 & 0 \\
\hline 24 & .001 & 0 & 0 & 0 & 0 & 0 & 0 & $0^{*}$ & 0 & 0 & 0 & 0 \\
\hline 25 & .001 & 0 & 0 & 0 & 0 & 0 & 0 & $0^{*}$ & 0 & 0 & 0 & 0 \\
\hline 26 & .001 & 0 & 0 & 0 & 0 & 0 & 0 & $0^{*}$ & 0 & 0 & 0 & 0 \\
\hline 27 & .001 & 0 & 0 & 0 & 0 & 0 & 0 & $0^{*}$ & 0 & 0 & 0 & 0 \\
\hline 28 & .001 & 0 & 0 & 0 & 0 & 0 & 0 & $0^{*}$ & 0 & 0 & 0 & 0 \\
\hline 29 & 0 & 0 & 0 & 0 & ------- & 0 & 0 & $0^{*}$ & 0 & 0 & 0 & 0 \\
\hline 30 & 0 & 0 & 0 & 0 & ------ & 0 & 0 & $0^{*}$ & 0 & 0 & 0 & 0 \\
\hline 31 & .002 & ------ & 0 & 0 & ----- & 0 & ---- & $0^{*}$ & ---- & 0 & 0 & ----- \\
\hline Total & 0.032 & 0.012 & 0 & 0 & 0 & 0 & 0 & 0 & 0 & 0 & 0 & 0 \\
\hline Mean & .001 & 0 & 0 & 0 & 0 & 0 & 0 & 0 & 0 & 0 & 0 & 0 \\
\hline $\operatorname{Max}$ & .002 & .002 & 0 & 0 & 0 & 0 & 0 & 0 & 0 & 0 & 0 & 0 \\
\hline Min & 0 & 0 & 0 & 0 & 0 & 0 & 0 & 0 & 0 & 0 & 0 & 0 \\
\hline Acre-Ft & .063 & .024 & 0 & 0 & 0 & 0 & 0 & 0 & 0 & 0 & 0 & 0 \\
\hline Wtr Year & 2006 & Total & 0.044 & Mean & 0 & & Max & 002 & Min & 0 & Acre-Ft & .087 \\
\hline Cal Year & 2005 & Total & 3.571 & Mean & .010 & & Max & 039 & Min & 0 & Acre-Ft & 7.08 \\
\hline
\end{tabular}




\section{S002 Burn Ground Spring at TA-16}

Location. Lat. $35^{\circ} 50^{\prime} 58^{\prime \prime}$, long. $106^{\circ} 20^{\prime} 17^{\prime \prime}, 150 \mathrm{yd}$ downstream from the SWSC line crossing of Cañon de Valle in Laboratory TA-16.

Gage. Data logger with $90^{\circ}$ weir. Elevation of gage is $7,420.8 \mathrm{ft}$ above NGVD from survey.

Period of Record. October 1, 1996, to September 30, 2006.

Remarks. Water discharge records fair. This spring is in the Cañon de Valle drainage.

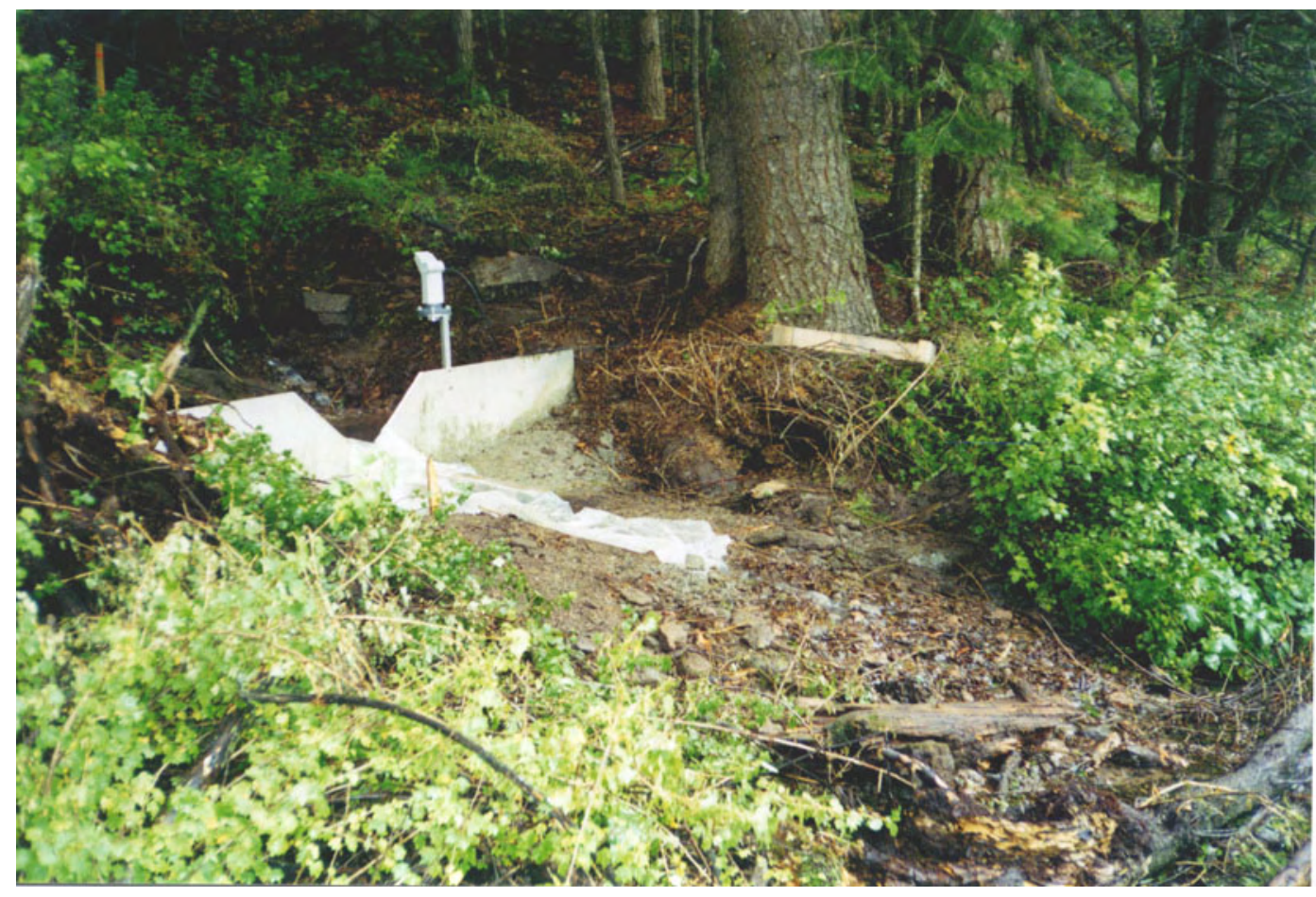




\section{S002 Burn Ground Spring at TA-16}

Daily Mean Discharge in Cubic Feet per Second

Water Year October 2005 to September 2006

\begin{tabular}{|c|c|c|c|c|c|c|c|c|c|c|c|c|}
\hline DAY & OCT & NOV & DEC & JAN & FEB & MAR & APR & MAY & JUN & JUL & AUG & SEP \\
\hline 1 & .015 & .010 & .009 & .007 & .004 & .006 & .007 & .004 & & .034 & .016 & \\
\hline 2 & .016 & .011 & .008 & .009 & .004 & .006 & .007 & .004 & & .038 & .015 & \\
\hline 3 & .016 & .010 & .009 & .010 & .004 & .006 & .007 & .004 & & .047 & .014 & \\
\hline 4 & .017 & .009 & .008 & .009 & .004 & .006 & .007 & .004 & & .051 & .014 & \\
\hline 5 & & .009 & .008 & .007 & .004 & .006 & .007 & .004 & & .056 & .013 & \\
\hline 6 & & .008 & .008 & .008 & .004 & .006 & .007 & .004 & & .058 & .014 & \\
\hline 7 & & .009 & .008 & .008 & .004 & .006 & .007 & .004 & & .058 & .014 & \\
\hline 8 & & .011 & .008 & .006 & .004 & .006 & .007 & .004 & & .056 & .015 & \\
\hline 9 & & .008 & .006 & .006 & .004 & .006 & .007 & .005 & & .054 & .019 & \\
\hline 10 & & .008 & .006 & .006 & .004 & .006 & .007 & .006 & & .052 & .019 & \\
\hline 11 & .011 & .008 & .006 & .007 & .004 & .006 & .007 & .006 & & .050 & .019 & \\
\hline 12 & .013 & .008 & .006 & .008 & .004 & .006 & .007 & .007 & & .050 & .019 & \\
\hline 13 & .013 & .008 & .006 & .008 & .004 & .006 & .007 & .008 & & .049 & .020 & \\
\hline 14 & .012 & .007 & .005 & .006 & .004 & .006 & .007 & .008 & & .049 & .021 & \\
\hline 15 & .011 & .008 & .005 & .005 & .005 & .006 & .007 & .007 & & .048 & .022 & \\
\hline 16 & .011 & .008 & .005 & .006 & .006 & .006 & .007 & .007 & & .081 & .016 & \\
\hline 17 & .012 & .007 & .006 & .005 & .006 & .006 & .007 & .006 & & .199 & .020 & \\
\hline 18 & .014 & .007 & .006 & .005 & .006 & .006 & .005 & .007 & & .180 & .022 & \\
\hline 19 & .013 & .007 & .006 & .005 & .006 & .006 & .004 & .007 & .008 & .160 & .021 & \\
\hline 20 & .013 & .007 & .006 & .005 & .006 & .006 & .004 & .007 & .008 & .141 & .023 & \\
\hline 21 & .014 & .007 & .006 & .005 & .006 & .006 & .004 & .007 & .008 & .122 & .024 & \\
\hline 22 & .014 & .007 & .006 & .005 & .006 & .006 & .004 & .008 & .009 & .102 & & \\
\hline 23 & .014 & .006 & .005 & .004 & .006 & .007 & .004 & .007 & .012 & .083 & & \\
\hline 24 & .015 & .006 & .005 & .004 & .006 & .007 & .004 & .007 & .009 & .064 & & \\
\hline 25 & .016 & .007 & .006 & .004 & .006 & .007 & .004 & & .007 & .044 & & \\
\hline 26 & .019 & .008 & .006 & .003 & .006 & .007 & .004 & & .007 & .025 & & \\
\hline 27 & .022 & .008 & .006 & .004 & .006 & .007 & .004 & & .008 & .006 & & \\
\hline 28 & .022 & .008 & .007 & .004 & .006 & .007 & .004 & & .008 & .004 & & \\
\hline 29 & .016 & .008 & .007 & .004 & ----- & .007 & .004 & & .014 & .016 & & \\
\hline 30 & .010 & .008 & .007 & .004 & ------ & .007 & .004 & & .031 & .017 & & \\
\hline 31 & .010 & ------ & .007 & .004 & ----- & .007 & ----- & & ------ & .016 & & ----- \\
\hline Total & 0.359 & 0.241 & 0.203 & 0.181 & 0.139 & 0.195 & 0.172 & 0.142 & 0.129 & 2.010 & 0.380 & \\
\hline Mean & .014 & .008 & .007 & .006 & .005 & .006 & .006 & .006 & .011 & .065 & .018 & \\
\hline Max & .022 & .011 & .009 & .010 & .006 & .007 & .007 & .008 & .031 & .199 & .024 & \\
\hline Min & .010 & .006 & .005 & .003 & .004 & .006 & .004 & .004 & .007 & .004 & .013 & \\
\hline Acre-Ft & .712 & .478 & .403 & .359 & .276 & .387 & .341 & .282 & .256 & 3.99 & .754 & \\
\hline Wtr Year & 2006 & Total & 4.151 & & & & Max & .199 & Min & .003 & Acre-Ft & 8.23 \\
\hline Cal Year & 2005 & Total & 6.722 & & & & Max & .063 & Min & .005 & Acre-Ft & 13.3 \\
\hline
\end{tabular}




\section{S003 Martin Spring at TA-16}

Location. Lat. $35^{\circ} 50^{\prime} 32^{\prime \prime}$, long. 106 $20^{\prime} 11^{\prime \prime}, 0.25$ mile south of Building 344 in Laboratory TA-16.

Gage. Data logger with $90^{\circ}$ weir. Elevation of gage is $7,429.5 \mathrm{ft}$ above NGVD from survey.

Period of Record. October 1, 1996, to September 30, 2006.

Remarks. Water discharge records good. This spring is in the Water Canyon drainage.

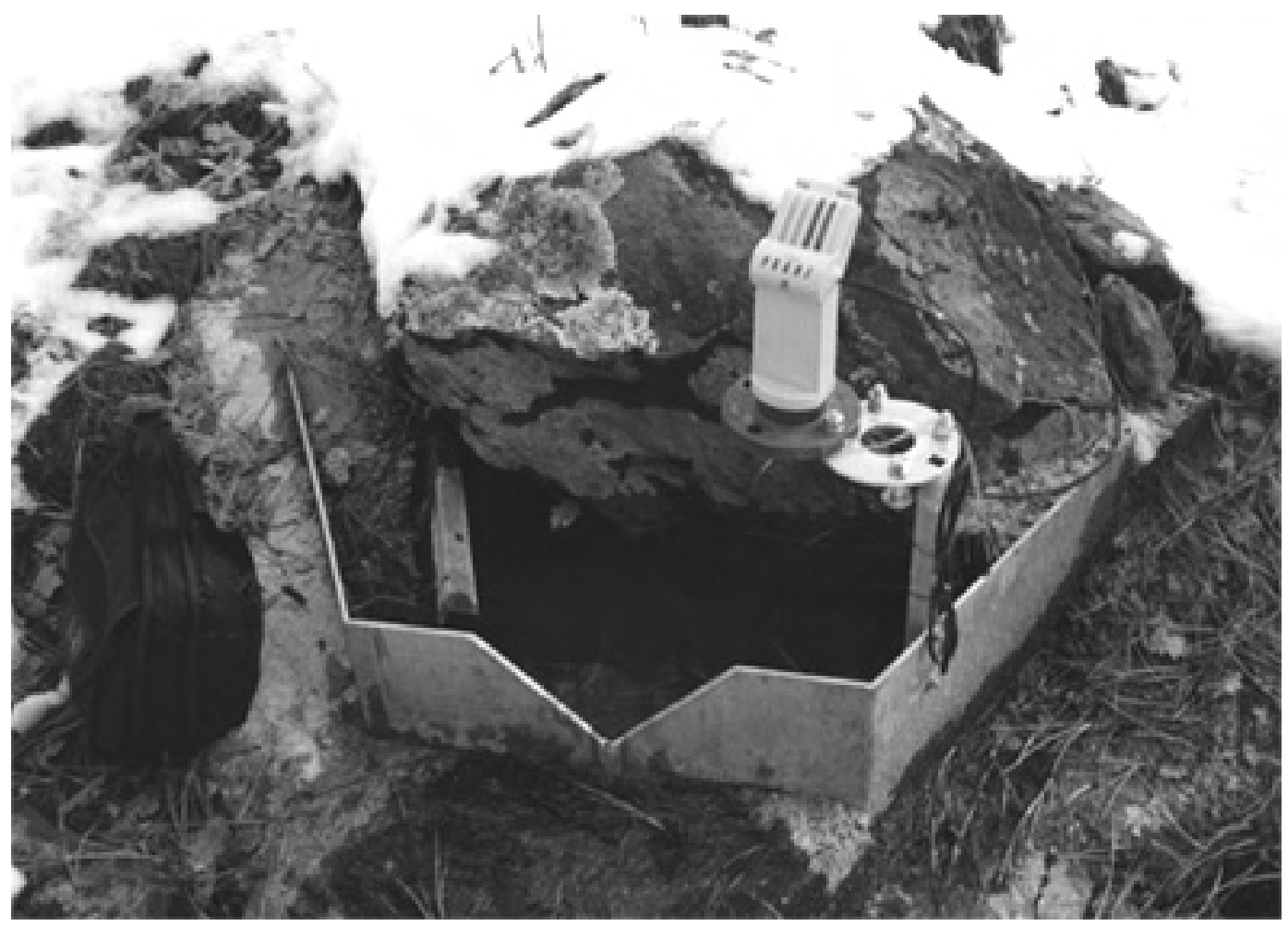




\section{S003 Martin Spring at TA-16}

Daily Mean Discharge in Cubic Feet per Second

Water Year October 2005 to September 2006

\begin{tabular}{|c|c|c|c|c|c|c|c|c|c|c|c|c|}
\hline DAY & OCT & NOV & DEC & JAN & FEB & MAR & APR & MAY & JUN & JUL & AUG & SEP \\
\hline 1 & .002 & .001 & .001 & 0 & .001 & 0 & 0 & 0 & & .001 & .002 & .002 \\
\hline 2 & .003 & .001 & .001 & 0 & .001 & 0 & 0 & 0 & & .001 & .001 & .004 \\
\hline 3 & .003 & .001 & .001 & 0 & 0 & 0 & 0 & .001 & & .001 & .002. & .002 \\
\hline 4 & .003 & .001 & .001 & 0 & 0 & 0 & 0 & .001 & & .001 & .004 & .002 \\
\hline 5 & .003 & .001 & .001 & 0 & 0 & 0 & 0 & .001 & & .001 & .004 & .003 \\
\hline 6 & .002 & .001 & .001 & 0 & 0 & .001 & 0 & .002 & & .001 & .003 & .002 \\
\hline 7 & .001 & .001 & .001 & 0 & .001 & .001 & 0 & .001 & & .001 & .005 & .002 \\
\hline 8 & .001 & .001 & .001 & 0 & .001 & .001 & 0 & .001 & & .001 & .003 & .002 \\
\hline 9 & .001 & .001 & 0 & 0 & .001 & 0 & 0 & & & .001 & .002 & .001 \\
\hline 10 & .001 & .001 & 0 & 0 & .001 & 0 & 0 & & & .001 & .002 & .005 \\
\hline 11 & .001 & .001 & 0 & 0 & .001 & .001 & 0 & & & .001 & .002 & .003 \\
\hline 12 & .001 & .001 & 0 & 0 & .001 & .001 & 0 & & & .001 & .001 & .003 \\
\hline 13 & .001 & .001 & 0 & 0 & .001 & .001 & 0 & & & .001 & .001 & .003 \\
\hline 14 & .002 & .001 & 0 & 0 & 0 & .001 & 0 & & & .001 & .001 & .002 \\
\hline 15 & .001 & 0 & 0 & 0 & 0 & .001 & 0 & & & .001 & .003 & .002 \\
\hline 16 & .001 & .001 & 0 & 0 & 0 & .001 & 0 & & & .001 & .002 & .002 \\
\hline 17 & .001 & .001 & 0 & 0 & 0 & .001 & 0 & & & .001 & .001 & .002 \\
\hline 18 & .001 & .001 & 0 & 0 & 0 & .001 & 0 & & & .001 & .002 & .002 \\
\hline 19 & .001 & .001 & 0 & 0 & 0 & .001 & 0 & & .001 & .001 & .002 & .002 \\
\hline 20 & .001 & .001 & 0 & 0 & 0 & .001 & 0 & & .001 & .001 & .002 & .002 \\
\hline 21 & .001 & .001 & 0 & 0 & 0 & .001 & 0 & & .001 & .001 & .002 & .002 \\
\hline 22 & .001 & .001 & 0 & 0 & 0 & .001 & 0 & & .001 & .001 & .001 & .002 \\
\hline 23 & .001 & 0 & 0 & 0 & 0 & .001 & 0 & & .001 & .001 & .001 & .001 \\
\hline 24 & .001 & 0 & 0 & 0 & 0 & .001 & 0 & & .001 & .001 & .001 & .001 \\
\hline 25 & .001 & 0 & 0 & .001 & 0 & .001 & 0 & & .001 & .001 & .001 & .001 \\
\hline 26 & .001 & 0 & 0 & .001 & 0 & .001 & 0 & & .001 & .001 & .002 & .001 \\
\hline 27 & .001 & .001 & 0 & .001 & 0 & .001 & 0 & & .001 & .003 & .005 & .001 \\
\hline 28 & .001 & .001 & 0 & .001 & 0 & .001 & 0 & & .001 & .004 & .005 & .001 \\
\hline 29 & .001 & .001 & 0 & .001 & ------ & 0 & .001 & & .001 & .003 & .005 & .001 \\
\hline 30 & .001 & .001 & 0 & .001 & ----- & 0 & .001 & & .001 & .001 & .005 & .001 \\
\hline 31 & .001 & ----- & 0 & .001 & ----- & 0 & ----- & & ----- & .002 & .001 & - \\
\hline Total & 0.042 & 0.025 & 0.008 & 0.007 & 0.009 & 0.021 & 0.002 & 0.007 & 0.012 & 0.039 & 0.074 & 0.060 \\
\hline Mean & .001 & .001 & 0 & 0 & 0 & .001 & 0 & .001 & .001 & .001 & .002 & .002 \\
\hline $\operatorname{Max}$ & .003 & .001 & .001 & .001 & .001 & .001 & .001 & .002 & .001 & .004 & .005 & .005 \\
\hline Min & .001 & 0 & 0 & 0 & 0 & 0 & 0 & 0 & .001 & .001 & .001 & .001 \\
\hline Acre-Ft & .083 & .050 & .016 & .014 & .018 & .042 & .004 & .014 & .024 & .077 & .147 & .119 \\
\hline Wtr Year & 2006 & Total & 0.306 & $\mathrm{M}$ & & & $\operatorname{Max}$ & 005 & Min & 0 & Acre-Ft & .607 \\
\hline Cal Year & 2005 & Total & 0.641 & & & & $\operatorname{Max}$ & 005 & Min & 0 & Acre-Ft & 1.27 \\
\hline
\end{tabular}




\section{Peak Flows}



Listed below are the peaks for the period of record beginning with water year 2000 through the current water year for all published stations.

The minimum time between peaks is $12 \mathrm{~h}$. That is, once the stream receded from peak flow, it was below that level for $12 \mathrm{~h}$. This enhances the individuality of the peak flows and eliminates any secondary peak from the same rain event. It also smoothes peak selection during snowmelt runoff periods.

Stations in this section are as follows:

E026 Los Alamos below Ice Rink

E030 Los Alamos above DP Canyon

E038 DP above TA-21

E040 DP above Los Alamos Canyon

E042 Los Alamos above SR 4

E050 Los Alamos below LA Weir

E055 Pueblo above Acid

E0555 South Fork Acid Canyon

E060 Pueblo above SR 502

E121 Sandia Right Fork at Power Plant

E1219 Sandia Canyon East of Power Plant

E1225 Sandia Tributary at Heavy Equipment

E123 Sandia below Wetlands

E125 Sandia above SR 4

E200 Mortandad below Effluent Canyon

E2015 Ten Site above Mortandad

E202 Mortandad above Sediment Traps

E203 Mortandad below Sediment Traps

E218 Cañada Del Buey near TA-46

E225 Cañada Del Buey near MDA G 
E230 Cañada Del Buey above SR 4

E240 Pajarito below SR-501

E241 Pajarito above Starmers

E242 Starmers above Pajarito

E2425 La Delfe above Pajarito

E243 Pajarito above Two Mile

E2435 Two Mile Tributary at TA-3

E244 Two Mile above Pajarito

E245 Pajarito above TA-18

E246 Three Mile above Pajarito

E2495 MDA G-7

E250 Pajarito above SR 4

E252 Water above SR 501

E2528 S-Site Canyon above Water

E253 Cañon de Valle above SR 501

E256 Cañon del Valle below MDA P

E262 Cañon De Valle above Water

E2625 Water below MDA AB

E263 Water at SR 4

E265 Water below SR 4

E267 Potrillo above SR 4

E275 Ancho below SR 4

E350 Rio De Los Frijoles at Bandalier 
E026 Los Alamos Canyon below Ice Rink

Period Starting: $\quad$ 00:00_02/26/2001

Period Ending: 24:00_09/30/2006

Peak Discharge above base of $15 \mathrm{cfs}$

\begin{tabular}{|l|c|c|}
\hline \multicolumn{1}{|c|}{ Time } & Gage Height & Discharge \\
\hline 18:30_07/02/2001 & 1.49 & 173 \\
\hline 00:05_07/14/2001 & 1.22 & 87 \\
\hline 14:20_07/26/2001 & 1.12 & 65 \\
\hline 15:45_08/09/2001 & 1.52 & 185 \\
\hline 23:30_06/21/2002 & 1.15 & 43 \\
\hline 11:15_05/21/2003 & 0.95 & 37 \\
\hline 17:00_08/11/2003 & 1.38 & 134 \\
\hline 16:30_09/06/2003 & 1.09 & 60 \\
\hline $05: 55 \_03 / 11 / 2004$ & 0.97 & 31 \\
\hline 13:05_06/29/2004 & 0.84 & 17 \\
\hline 18:40_04/19/2005 & 0.84 & 21 \\
\hline 12:25_08/08/2006 & 1.62 & 83 \\
\hline
\end{tabular}




\section{E030 Los Alamos Canyon above DP Canyon}

Period Starting: $\quad$ 00:00_10/01/1994

Period Ending: 24:00_09/30/2006

Peak Discharge above base of $10 \mathrm{cfs}$

\begin{tabular}{|l|c|c|}
\hline Time & Gage Height & Discharge \\
\hline 18:05_06/02/2000 & 1.6 & 13 \\
\hline 15:40_10/23/2000 & 1.85 & 25 \\
\hline 19:55_07/02/2001 & 2.02 & 30 \\
\hline 20:00_07/26/2001 & 1.74 & 17 \\
\hline 17:05_08/09/2001 & 2.39 & 60 \\
\hline 19:20_08/16/2001 & 1.99 & 28 \\
\hline $00: 25 \_06 / 22 / 2002$ & 2.88 & 125 \\
\hline 15:05_05/20/2003 & 1.45 & 11 \\
\hline 15:10_08/23/2003 & 1.68 & 15 \\
\hline 17:30_09/06/2003 & 1.55 & 12 \\
\hline 20:55_07/24/2004 & 1.66 & 14 \\
\hline 16:50_07/15/2005 & 1.6 & 12 \\
\hline $09: 15 \_08 / 12 / 2005$ & 1.56 & 11 \\
\hline 14:25_08/24/2005 & 1.97 & 27 \\
\hline 13:25_08/08/2006 & 2.65 & 100 \\
\hline $12: 55 \_08 / 25 / 2006$ & 2.17 & 40 \\
\hline
\end{tabular}




\section{E038 DP Canyon above TA-21}

Period Starting: $\quad$ 00:00_10/06/2000

Period Ending: $\quad$ 24:00_09/30/2006

Peak Discharges above base of $50 \mathrm{cfs}$

\begin{tabular}{|c|c|c|}
\hline Time & Gage Height & Discharge \\
\hline $17: 55 \_10 / 12 / 2000$ & 1.83 & 51 \\
\hline $14: 25 \_10 / 16 / 2000$ & 2.19 & 75 \\
\hline 14:05_10/23/2000 & 2.05 & 65 \\
\hline 17:40_10/27/2000 & 3.30 & 174 \\
\hline 16:00_05/13/2001 & 3.32 & 176 \\
\hline 12:45_06/27/2001 & 3.62 & 208 \\
\hline 17:30_07/02/2001 & 2.82 & 127 \\
\hline 13:40_08/04/2001 & 3.16 & 160 \\
\hline $23: 15 \_06 / 21 / 2002$ & 3.65 & 212 \\
\hline 05:50_09/10/2002 & 2.03 & 64 \\
\hline $15: 25 \_08 / 07 / 2003$ & 1.87 & 54 \\
\hline 16:30_08/11/2003 & 1.89 & 55 \\
\hline 12:45_08/17/2003 & 1.86 & 53 \\
\hline 13:50_08/23/2003 & 3.63 & 209 \\
\hline 12:45_07/18/2004 & 2.93 & 137 \\
\hline 19:40_07/24/2004 & 4.36 & 295 \\
\hline $15: 25 \_09 / 27 / 2004$ & 2.77 & 122 \\
\hline 09:00_10/05/2004 & 2.50 & 99 \\
\hline $16: 25 \_04 / 16 / 2005$ & 1.88 & 70 \\
\hline 15:40_07/15/2005 & 2.36 & 88 \\
\hline 15:00_07/20/2005 & 2.05 & 65 \\
\hline 17:00_08/04/2005 & 3.16 & 162 \\
\hline 21:00_08/11/2005 & 2.86 & 104 \\
\hline 11:40_08/22/2005 & 2.64 & 111 \\
\hline $13: 45 \_08 / 24 / 2005$ & 2.86 & 131 \\
\hline $16: 25 \_09 / 28 / 2005$ & 2.56 & 104 \\
\hline 23:35_10/02/2005 & 2.75 & 120 \\
\hline 16:05_06/29/2006 & 4.00 & 227 \\
\hline 14:10_08/01/2006 & 3.30 & 151 \\
\hline $12: 15 \_08 / 08 / 2006$ & 4.26 & 258 \\
\hline 11:20_08/12/2006 & 2.37 & 70 \\
\hline $12: 35 \_08 / 25 / 2006$ & 3.11 & 132 \\
\hline
\end{tabular}




\section{E040 DP Canyon above Los Alamos Canyon}

Period Starting: $\quad 00: 00 \_10 / 01 / 2000$

Period Ending: 24:00_09/30/2006

Peak discharge above base of $30 \mathrm{cfs}$

\begin{tabular}{|l|c|c|}
\hline \multicolumn{1}{|c|}{ Time } & Gage Height & Discharge \\
\hline 19:15_07/02/2001 & 3.56 & 33 \\
\hline 00:00_06/21/2002 & 3.57 & 90 \\
\hline 15:30_08/23/2003 & 3.32 & 51 \\
\hline Unknown_07/24/2004 & 3.85 & 160 \\
\hline 16:50_08/20/2004 & 3.3 & 48 \\
\hline 17:45_08/04/2005 & 3.54 & 84 \\
\hline 08:30_08/12/2005 & 3.56 & 80 \\
\hline 12:25_08/22/2005 & 3.45 & 69 \\
\hline 14:30_08/24/2005 & 3.721 & 123 \\
\hline 17:15_09/28/2005 & 3.41 & 63 \\
\hline 17:00_06/29/2006 & 3.64 & 81 \\
\hline 11:45_07/09/2006 & 3.4 & 53 \\
\hline 14:50_08/01/2006 & 3.47 & 60 \\
\hline 12:50_08/08/2006 & 5.65 & 452 \\
\hline
\end{tabular}


E042 Los Alamos Canyon above SR 4

Period Starting: $\quad 00: 00 \_10 / 01 / 2000$

Period Ending: 24:00_09/30/2006

Peak Discharge above base of $40 \mathrm{cfs}$

\begin{tabular}{|l|c|c|}
\hline \multicolumn{1}{|c|}{ Time } & Gage Height & Discharge \\
\hline 19:35_10/27/2000 & 2.31 & 59 \\
\hline 20:40_07/02/2001 & 2.52 & 91 \\
\hline 20:30_07/26/2001 & 2.24 & 50 \\
\hline 17:45_08/09/2001 & 2.83 & 146 \\
\hline 20:00_08/16/2001 & 2.62 & 107 \\
\hline 00:45_06/22/2002 & 2.90 & 160 \\
\hline 16:00_08/23/2003 & 2.54 & 94 \\
\hline 21:45_07/24/2004 & 2.16 & 40 \\
\hline $07: 15 \_08 / 12 / 2005$ & 2.43 & 77 \\
\hline 15:05_08/24/2005 & 2.82 & 144 \\
\hline 14:50_08/25/2005 & 2.37 & 67 \\
\hline $00: 05 \_07 / 05 / 2006$ & 3.42 & 246 \\
\hline 13:20_08/08/2006 & 3.76 & 240 \\
\hline 13:25_08/25/2006 & 3.62 & 284 \\
\hline
\end{tabular}


E050 Los Alamos Canyon below LA Weir

Period Starting: $\quad$ 00:00_05/16/2001

Period Ending: 24:00_09/30/2006

Peak Discharge above base of $30 \mathrm{cfs}$

\begin{tabular}{|l|c|c|}
\hline \multicolumn{1}{|c|}{ Time } & Gage Height & Discharge \\
\hline 18:15_08/09/2001 & 1.55 & 43 \\
\hline 20:20_08/16/2001 & 1.46 & 38 \\
\hline 16:15_08/23/2003 & 1.55 & 43 \\
\hline 21:10_07/24/2004 & 1.39 & 34 \\
\hline 15:20_08/24/2005 & 1.63 & 48 \\
\hline 00:15_07/05/2006 & 2.56 & 148 \\
\hline 13:40_08/08/2006 & 3.2 & 252 \\
\hline 13:50_08/25/2006 & 1.89 & 72 \\
\hline
\end{tabular}

E055 Pueblo above Acid

Period Starting: $\quad$ 00:00_10/01/2002

Period Ending: 24:00_09/30/2006

Peak Discharge above base of $20 \mathrm{cfs}$

\begin{tabular}{|l|c|c|}
\hline \multicolumn{1}{|c|}{ Time } & Gage Height & Discharge \\
\hline 17:25_08/11/2003 & 2.63 & 26 \\
\hline 15:30_08/23/2003 & 6.64 & 1180 \\
\hline 16:25_08/26/2003 & 3.18 & 61 \\
\hline 16:30_09/06/2003 & 5.65 & 651 \\
\hline Unknown_07/24/2004 & 4.90 & 523 \\
\hline 09:30_10/05/2004 & 3.05 & 28 \\
\hline 15:50_07/15/2005 & 2.52 & 30 \\
\hline 20:30_08/13/2005 & 3.69 & 123 \\
\hline 13:30_08/24/2005 & 2.86 & 52 \\
\hline 12:20_08/08/2006 & 7.50 & 1780 \\
\hline 14:45_08/25/2006 & 2.76 & 45 \\
\hline
\end{tabular}




\section{E0555 South Fork Acid Canyon}

Period Starting: $\quad$ 00:00_08/18/2004

Period Ending: 24:00_09/30/2006

Peak Discharge above base of $10 \mathrm{cfs}$

\begin{tabular}{|c|c|c|}
\hline Time & Gage Height & Discharge \\
\hline 13:30_08/24/2005 & 5.34 & 17 \\
\hline 14:05_08/01/2006 & 6.20 & 88 \\
\hline 11:30_08/07/2006 & 5.69 & 38 \\
\hline 12:00_08/08/2006 & 6.22 & 108 \\
\hline 14:35_08/25/2006 & 5.35 & 18 \\
\hline 12:10_09/11/2006 & 5.17 & 12 \\
\hline
\end{tabular}




\section{E060 Pueblo above SR 502}

Period Starting: $\quad$ 00:00_10/10/200

Period Ending: 24:00_9/30/06

Peak Discharge above base of $75 \mathrm{cfs}$

\begin{tabular}{|l|c|c|}
\hline \multicolumn{1}{|c|}{ Time } & Gage Height & Discharge \\
\hline 00:15_10/24/2000 & 8.11 & 147 \\
\hline 20:00_07/02/2001 & 10.46 & 1440 \\
\hline 20:15_07/26/2001 & 7.66 & 114 \\
\hline 17:10_08/09/2001 & 8.38 & 244 \\
\hline 15:00_08/11/2001 & 8.33 & 231 \\
\hline 20:35_08/16/2001 & 8.03 & 165 \\
\hline 01:00_06/22/2002 & 9.47 & 582 \\
\hline 16:20_08/23/2003 & 9.72 & 749 \\
\hline $8: 15 \_09 / 06 / 2003$ & 8.71 & 243 \\
\hline 22:50_07/24/2004 & 9.11 & 504 \\
\hline 17:30_07/27/2004 & 8.53 & 262 \\
\hline 16:20_10/05/2004 & 7.95 & 77 \\
\hline $00: 40 \_08 / 14 / 2005$ & 8.77 & 116 \\
\hline $17: 30 \_08 / 24 / 2005$ & 8.61 & 85 \\
\hline $01: 40 \_07 / 05 / 2006$ & 8.82 & 117 \\
\hline 18:30_08/07/2006 & 8.86 & 127 \\
\hline 14:30_08/08/2006 & 11.75 & 1930 \\
\hline
\end{tabular}




\section{E121 Sandia Right Fork at Power Plant}

Period Starting: $\quad$ 00:00_07/06/2002

Period Ending: 24:00_09/30/2006

Peak Discharge above base of 35 cfs

\begin{tabular}{|l|c|c|}
\hline \multicolumn{1}{|c|}{ Time } & Gage Height & Discharge \\
\hline 23:05_06/21/2002 & 8.31 & 191 \\
\hline 13:15_07/23/2004 & 7.33 & 85 \\
\hline 19:40_07/24/2004 & 7.35 & 102 \\
\hline 11:20_08/18/2004 & 7.06 & 61 \\
\hline 15:10_07/15/2005 & 7.56 & 111 \\
\hline 16:55_08/04/2005 & 6.94 & 48 \\
\hline 06:25_08/12/2005 & 6.82 & 38 \\
\hline 13:00_08/24/2005 & 7.31 & 83 \\
\hline 20:00_07/03/2006 & 6.96 & 44 \\
\hline 14:00_08/07/2006 & 7.01 & 47 \\
\hline 12:20_08/08/2006 & 7.23 & 61 \\
\hline 11:55_08/25/2006 & 7.13 & 55 \\
\hline
\end{tabular}

E1219 Sandia Canyon East of Power Plant

Period Starting: 00:00_02/23/2006

Period Ending: 24:00_09/30/2006

Peak Discharge above base of $2.0 \mathrm{cfs}$

\begin{tabular}{|c|c|c|}
\hline Time & Gage Height & Discharge \\
\hline 12:20_08/08/2006 & 0.77 & 2.1 \\
\hline 12:15_08/25/2006 & 1.01 & 3.1 \\
\hline
\end{tabular}




\section{E1225 Sandia Canyon Tributary at Heavy Equipment}

Period Starting: $\quad$ 00:00_05/21/2001

Period Ending: 24:00_09/30/2006

Peak Discharge above base of $5.0 \mathrm{cfs}$

\begin{tabular}{|c|c|c|}
\hline Time & Gage Height & Discharge \\
\hline 02:00_05/25/2003 & 1.22 & 5.3 \\
\hline 16:10_06/29/2006 & 1.28 & 5.8 \\
\hline 20:00_07/03/2006 & 1.26 & 5.7 \\
\hline 12:15_08/25/2006 & 1.50 & 6.6 \\
\hline 06:15_09/23/2006 & 1.24 & 5.5 \\
\hline
\end{tabular}




\section{E123 Sandia below Wetlands}

Period Starting: $\quad$ 00:00_01/10/1999

Period Ending: 24:00_09/30/2006

Peak Discharge above base of 30 cfs

\begin{tabular}{|l|c|c|}
\hline \multicolumn{1}{|c|}{ Time } & Gage Height & Discharge \\
\hline 14:40_07/06/1999 & 3.04 & 34 \\
\hline 12:40_08/10/1999 & 2.98 & 32 \\
\hline 13:45_09/14/1999 & 3.45 & 49 \\
\hline 21:40_09/16/1999 & 3.02 & 34 \\
\hline 18:55_07/02/2001 & 3.45 & 49 \\
\hline 17:00_08/05/2001 & 3.37 & 46 \\
\hline 18:50_08/16/2001 & 3.48 & 50 \\
\hline Unknown_06/21/2002 & 4.04 & 76 \\
\hline 12:40_05/24/2003 & 3.13 & 37 \\
\hline 15:30_08/07/2003 & 3.06 & 35 \\
\hline 17:00_08/11/2003 & 3.36 & 45 \\
\hline 14:15_08/23/2003 & 4.23 & 88 \\
\hline 16:25_09/06/2003 & 3.07 & 35 \\
\hline 20:15_07/24/2004 & 3.05 & 35 \\
\hline 11:55_08/18/2004 & 2.97 & 32 \\
\hline 16:00_07/15/2005 & 4.38 & 85 \\
\hline 13:45_08/24/2005 & 2.91 & 30 \\
\hline 14:35_08/07/2006 & 3.34 & 32 \\
\hline 12:40_08/08/2006 & 4.04 & 74 \\
\hline 12:20_08/25/2006 & 4.04 & 75 \\
\hline
\end{tabular}




\section{E125 Sandia above SR 4}

Period Starting: $\quad$ 00:00_10/01/1994

Period Ending: 24:00_09/30/2006

Peak Discharge above $3 \mathrm{cfs}$

\begin{tabular}{|c|c|c|}
\hline Time & Gage Height & Discharge \\
\hline 14:40_08/28/2002 & 2.01 & 18 \\
\hline 13:00_08/22/2003 & 1.26 & 86 \\
\hline 13:15_09/29/2005 & 1.52 & 5.6 \\
\hline 14:25_08/25/2006 & 3.60 & 59 \\
\hline
\end{tabular}

\section{E200 Mortandad below Effluent Canyon}

Period Starting: $\quad$ 00:00_10/01/1996

Period Ending: 24:00_09/30/2006

Peak Discharge above base of 13 cfs

\begin{tabular}{|l|c|c|}
\hline Time & Gage Height & Discharge \\
\hline 12:50_06/27/2001 & 3.26 & 49 \\
\hline 18:40_08/16/2001 & 2.40 & 18 \\
\hline 00:20_06/22/2002 & 2.16 & 14 \\
\hline 14:00_08/23/2003 & 2.73 & 24 \\
\hline 20:30_07/24/2004 & 2.70 & 23 \\
\hline 15:35_07/15/2005 & 2.24 & 14 \\
\hline 16:25_06/29/2006 & 3.95 & 68 \\
\hline 11:25_07/09/2006 & 2.74 & 24 \\
\hline 12:20_08/01/2006 & 2.23 & 13 \\
\hline 12:40_08/08/2006 & 2.62 & 21 \\
\hline 12:40_08/25/2006 & 5.38 & 448 \\
\hline
\end{tabular}


E2015 Ten Site above Mortandad

Period Starting: $\quad$ 00:00_01/10/2000

Period Ending: 24:00_09/30/2006

Peak Discharge above base of $10 \mathrm{cfs}$

\begin{tabular}{|c|c|c|}
\hline Time & Gage Height & Discharge \\
\hline 14:20_08/24/2005 & 3.10 & 11 \\
\hline 12:55_08/25/2006 & 4.60 & 303 \\
\hline
\end{tabular}

\section{E202 Mortandad above Sediment Traps}

Period Starting: 00:00_01/10/2000

Period Ending: 24:00_09/30/2006

Peak Discharge above base of $10 \mathrm{cfs}$

\begin{tabular}{|c|c|c|}
\hline \multicolumn{1}{|c|}{ Time } & Gage Height & Discharge \\
\hline 14:40_08/24/2005 & 2.687 & 48 \\
\hline Unknown_08/25/2006 & Unknown & 292 \\
\hline
\end{tabular}


E203 Mortandad below Sediment Traps

Period Starting: $\quad$ 00:00_10/01/1996

Period Ending: 24:00_09/30/2006

Peak Discharge above base of $1.0 \mathrm{cfs}$

\begin{tabular}{|c|c|c|}
\hline Time & Gage Height & Discharge \\
\hline 14:05_08/25/2006 & Unknown & 220 \\
\hline
\end{tabular}

\section{E218 Cañada del Buey near TA-46}

Period Starting: $\quad$ 00:00_06/01/2000

Period Ending: 24:00_09/30/2006

Peak Discharge above base of $8.0 \mathrm{cfs}$

\begin{tabular}{|l|c|c|}
\hline Time & Gage Height & Discharge \\
\hline 19:10_07/29/2000 & 3.20 & 125 \\
\hline 13:40_08/19/2000 & 1.54 & 16 \\
\hline 14:25_10/23/2000 & 1.01 & 8 \\
\hline 13:20_06/27/2001 & 1.82 & 20 \\
\hline 14:05_08/23/2003 & 1.64 & 17 \\
\hline 17:25_07/23/2004 & 1.73 & 19 \\
\hline 20:20_07/24/2004 & 1.43 & 14 \\
\hline 19:50_07/20/2005 & 1.01 & 8 \\
\hline 13:40_08/24/2005 & 1.34 & 13 \\
\hline 13:00_08/25/2006 & 3.40 & 228 \\
\hline
\end{tabular}


E225 Cañada del Buey near MDA G

Period Starting: $\quad$ 00:00_01/10/2000

Period Ending: $\quad$ 24:00_09/30/2006

Peak Discharge above base of $5.0 \mathrm{cfs}$

\begin{tabular}{|c|c|c|}
\hline Time & Gage Height & Discharge \\
\hline 20:00_08/25/2003 & 2.67 & 16 \\
\hline
\end{tabular}

\section{E230 Cañada del Buey above SR 4}

Period Starting: $\quad$ 00:00_01/10/1994

Period Ending: 24:00_09/30/2006

Peak Discharge above base of $20 \mathrm{cfs}$

\begin{tabular}{|l|c|c|}
\hline \multicolumn{1}{|c|}{ Time } & Gage Height & Discharge \\
\hline 20:20_08/09/2000 & 1.37 & 33 \\
\hline 17:15_08/18/2000 & 1.33 & 30 \\
\hline 14:10_08/28/2002 & 2.92 & 168 \\
\hline 14:55_09/09/2002 & 1.44 & 42 \\
\hline 17:05_05/26/2003 & 2.25 & 100 \\
\hline 19:50_08/25/2003 & 1.81 & 64 \\
\hline 15:25_09/28/2005 & 1.30 & 33 \\
\hline $00: 20 \_07 / 05 / 2006$ & 1.59 & 51 \\
\hline 11:55_08/01/2006 & 1.10 & 21 \\
\hline $00: 40 \_08 / 06 / 2006$ & 1.65 & 54 \\
\hline
\end{tabular}




\section{E240 Pajarito below SR 501}

Period Starting: $\quad$ 00:00_10/01/1995

Period Ending: $\quad$ 24:00_09/30/2006

Peak Discharge above base of $5 \mathrm{cfs}$

\begin{tabular}{|l|c|c|}
\hline \multicolumn{1}{|c|}{ Time } & Gage Height & Discharge \\
\hline 17:40_07/26/2001 & 1.43 & 54 \\
\hline 23:10_08/07/2001 & 0.80 & 12 \\
\hline 15:00_08/09/2001 & 2.32 & 155 \\
\hline 21:50_06/21/2002 & 2.45 & 173 \\
\hline 14:00_08/23/2003 & 1.50 & 61 \\
\hline Unknown_07/15/2005 & 2.40 & 103 \\
\hline 19:50_08/11/2005 & 1.40 & 18 \\
\hline 13:10_08/24/2005 & 1.16 & 6.3 \\
\hline 13:25_08/08/2006 & 1.22 & 16 \\
\hline 13:10_09/11/2006 & 1.06 & 8.9 \\
\hline
\end{tabular}

\section{E241 Pajarito above Starmers}

Period Starting: $\quad$ 00:00_01/10/1999

Period Ending: 24:00_09/30/2006

Peak Discharge above base of $10 \mathrm{cfs}$

\begin{tabular}{|c|c|c|}
\hline Time & Gage Height & Discharge \\
\hline 12:30_06/28/2000 & 5.00 & 300 \\
\hline 15:00_08/09/2001 & 3.60 & 109 \\
\hline 22:00_06/21/2002 & 3.92 & 207 \\
\hline 16:55_08/11/2003 & 2.98 & 25 \\
\hline $05: 20 \_02 / 04 / 2005$ & 2.59 & 11 \\
\hline 15:20_07/15/2005 & 3.10 & 31 \\
\hline 13:25_08/24/2005 & 3.50 & 74 \\
\hline 12:30_08/08/2006 & 2.84 & 20 \\
\hline
\end{tabular}




\section{E242 Starmers above Pajarito}

Period Starting: $\quad$ 00:00_01/10/1999

Period Ending: 24:00_09/30/2006

Peak Discharge above base of $10 \mathrm{cfs}$

\begin{tabular}{|l|c|c|}
\hline \multicolumn{1}{|c|}{ Time } & Gage Height & Discharge \\
\hline 12:40_06/28/2000 & 2.75 & 180 \\
\hline 15:15_07/08/2000 & 1.99 & 22 \\
\hline 17:20_08/05/2001 & 2.68 & 103 \\
\hline 14:55_08/09/2001 & 2.1 & 28 \\
\hline 15:15_07/15/2005 & 2.47 & 93 \\
\hline Unknown_7/23/3004 & 1.32 & 19 \\
\hline 13:20_08/24/2005 & 2.33 & 29 \\
\hline 12:30_08/08/2006 & 3.89 & 17 \\
\hline
\end{tabular}

\section{E2425 La Delfe above Pajarito}

Period Starting: $\quad$ 00:00_10/01/1999

Period Ending: 24:00_09/30/2006

Peak Discharge above base of $6.0 \mathrm{cfs}$

\begin{tabular}{|c|c|c|}
\hline Time & Gage Height & Discharge \\
\hline 23:30_06/21/2002 & 1.91 & 6.6 \\
\hline 15:40_07/15/2005 & 2.07 & 9.4 \\
\hline 13:50_08/24/2005 & 2.64 & 30 \\
\hline 12:50_08/08/2006 & 2.08 & 9.6 \\
\hline 14:10_08/25/2006 & 2.21 & 12 \\
\hline 12:50_09/11/2006 & 1.93 & 6.9 \\
\hline
\end{tabular}




\section{E243 Pajarito above Two Mile}

Period Starting: $\quad$ 00:00_10/01/2002

Period Ending: $\quad$ 24:00_09/30/2006

Peak Discharge above base of $5.0 \mathrm{cfs}$

\begin{tabular}{|c|c|c|}
\hline Time & Gage Height & Discharge \\
\hline 22:35_06/21/2002 & 1.73 & 41 \\
\hline 17:35_04/11/2003 & 0.99 & 7.8 \\
\hline 20:35_07/24/2004 & 1.07 & 9.8 \\
\hline 14:05_08/21/2005 & 4.38 & 272 \\
\hline 13:10_08/08/2006 & 2.99 & 101 \\
\hline
\end{tabular}

\section{E2435 Two Mile Tributary at TA-3}

Period Starting: $\quad$ 00:00_05/25/2006

Period Ending: 24:00_09/30/2006

Peak Discharge above base of $6.0 \mathrm{cfs}$

\begin{tabular}{|c|c|c|}
\hline \multicolumn{1}{|c|}{ Time } & Gage Height & Discharge \\
\hline 20:05_07/03/2006 & 1.49 & 7.4 \\
\hline 12:25_08/08/2006 & 1.77 & 9.6 \\
\hline 14:45_08/19/2006 & 1.42 & 6.9 \\
\hline 11:55_08/25/2006 & 1.76 & 9.5 \\
\hline
\end{tabular}




\section{E244 Two Mile above Pajarito}

Period Starting: $\quad$ 00:00_01/01/2004

Period Ending: $\quad$ 24:00_09/30/2006

Peak Discharge above base of $30 \mathrm{cfs}$

\begin{tabular}{|l|c|c|}
\hline \multicolumn{1}{|c|}{ Time } & Gage Height & Discharge \\
\hline 08:05_08/23/2003 & 3.08 & 103 \\
\hline 20:10_07/24/2004 & 3.40 & 135 \\
\hline 15:55_07/15/2005 & 3.95 & 203 \\
\hline 14:25_08/24/2005 & 5.42 & 484 \\
\hline 13:15_08/08/2006 & 4.16 & 231 \\
\hline 12:45_08/25/2006 & 6.01 & 628 \\
\hline
\end{tabular}




\section{E245 Pajarito above TA-18}

Period Starting: $\quad$ 00:00_10/06/1994

Period Ending: $\quad$ 24:00_09/30/2006

Peak Discharge above base of $25 \mathrm{cfs}$

\begin{tabular}{|l|c|c|}
\hline \multicolumn{1}{|c|}{ Time } & Gage Height & Discharge \\
\hline 13:20_06/28/2000 & 5.03 & 517 \\
\hline 15:55_10/23/2000 & 2.55 & 31 \\
\hline $02: 30 \_10 / 28 / 2000$ & 2.73 & 37 \\
\hline 11:25_03/17/2001 & 1.81 & 28 \\
\hline 13:15_06/27/2001 & 3.54 & 140 \\
\hline 15:40_07/19/2001 & 2.31 & 53 \\
\hline 17:10_08/05/2001 & 2.27 & 51 \\
\hline 23:20_06/21/2002 & 3.54 & 141 \\
\hline 18:50_08/11/2003 & 2.15 & 44 \\
\hline Unknown_07/24/2004 & 2.66 & 74 \\
\hline $00: 45 \_01 / 04 / 2005$ & 2.13 & 43 \\
\hline $07: 10 \_02 / 12 / 2005$ & 1.86 & 31 \\
\hline 16:40_07/15/2005 & 3.21 & 112 \\
\hline 10:00_08/12/2005 & 2.73 & 78 \\
\hline 14:45_08/24/2005 & 4.02 & 373 \\
\hline $13: 45 \_08 / 08 / 2006$ & 3.19 & 110 \\
\hline $13: 15 \_08 / 25 / 2006$ & 5.10 & 425 \\
\hline $13: 55 \_09 / 11 / 2006$ & 1.90 & 32 \\
\hline
\end{tabular}


E246 Three Mile above Pajarito

Period Starting: $\quad$ 00:00_10/01/1998

Period Ending: 24:00_09/30/2006

Peak Discharge above base of $5.0 \mathrm{cfs}$

\begin{tabular}{|c|c|c|}
\hline Time & Gage Height & Discharge \\
\hline 19:00_10/27/2000 & 2.00 & 25 \\
\hline 14:55_08/23/2003 & 2.08 & 73 \\
\hline 14:15_07/23/2004 & 2.42 & 160 \\
\hline 13:20_08/18/2004 & 2.09 & 75 \\
\hline 18:15_08/20/2004 & 2.53 & 173 \\
\hline 13:15_08/25/2006 & 3.50 & 536 \\
\hline
\end{tabular}

\section{E2495 MDA G-7}

Period Starting: $\quad$ 00:00_02/02/2004

Period Ending: 00:00_09/30/2006

Peak Discharge above base of $5.0 \mathrm{cfs}$

\begin{tabular}{|c|c|c|}
\hline Time & Gage Height & Discharge \\
\hline 16:05_08/07/2006 & 1.5 & 5.7 \\
\hline
\end{tabular}




\section{E250 Pajarito above SR 4}

Period Starting: $\quad$ 00:00_10/01/1994

Period Ending: 24:00_09/30/2006

Peak Discharge above base of $5 \mathrm{cfs}$

\begin{tabular}{|l|c|c|}
\hline Time & Gage Height & Discharge \\
\hline 18:50_01/08/1996 & 3.43 & 14 \\
\hline 15:40_06/17/1999 & 3.89 & 20 \\
\hline 17:10_06/28/2000 & 3.44 & 14 \\
\hline 06:30_10/28/2000 & 3.27 & 12 \\
\hline 21:45_08/09/2001 & 3.26 & 12 \\
\hline 23:35_08/16/2001 & 3.72 & 22 \\
\hline 04:35_06/22/2002 & 3.86 & 26 \\
\hline 13:05_02/12/2005 & 2.89 & 6.2 \\
\hline 19:30_08/24/2005 & 4.16 & 36 \\
\hline 15:10_09/29/2005 & 3.39 & 14 \\
\hline 17:10_08/25/2006 & 4.62 & 206 \\
\hline
\end{tabular}


E252 Water above SR 501

Period Starting: $\quad$ 00:00_10/06/1995

Period Ending: $\quad$ 24:00_09/30/2006

Peak Dishcarge above 2 cfs

\begin{tabular}{|l|c|c|}
\hline Time & Gage Height & Discharge \\
\hline 12:30_06/28/2000 & 7.9 & 840 \\
\hline $07: 20 \_04 / 24 / 2000$ & 1.12 & 2.25 \\
\hline 23:30_07/13/2001 & 3.01 & 9.5 \\
\hline 14:25_07/22/2001 & 4.37 & 255 \\
\hline 17:35_07/26/2001 & 3.72 & 80 \\
\hline 12:00_08/03/2001 & 3.10 & 14 \\
\hline 18:30_08/05/2001 & 3.11 & 15 \\
\hline 21:55_06/21/2002 & 3.28 & 114 \\
\hline $05: 40 \_09 / 10 / 2002$ & 3.10 & 14 \\
\hline 12:30_08/28/2003 & 2.75 & 21 \\
\hline 14:20_08/14/2006 & 2.69 & 2.5 \\
\hline
\end{tabular}




\section{E2528 S-Site Canyon above Water}

Period Starting: $\quad$ 00:00_04/01/1999

Period Ending: 24:00_09/30/2006

Peak Discharge above base of 1.00

\begin{tabular}{|l|c|c|}
\hline \multicolumn{1}{|c|}{ Time } & Gage Height & Discharge \\
\hline 17:35_07/29/2000 & 1.88 & 2.7 \\
\hline Unknown_08/03/2201 & 2.61 & 10 \\
\hline 17:15_08/20/2004 & 4.03 & 162 \\
\hline 14:15_08/24/2005 & 2.8 & 13 \\
\hline 17:05_06/29/2006 & 3.32 & 32 \\
\hline 23:50_08/20/2006 & 1.87 & 2.6 \\
\hline 13:00_08/25/2006 & 3.71 & 77 \\
\hline 13:40_09/11/2006 & 2.15 & 4.8 \\
\hline
\end{tabular}

E253 Cañon de Valle above SR 501

Period Starting: $\quad$ 00:00_10/06/1995

Period Ending: $\quad$ 24:00_09/30/2006

Peak Discharge above base of cfs

\begin{tabular}{|l|c|c|}
\hline \multicolumn{1}{|c|}{ Time } & Gage Height & Discharge \\
\hline 12:30_06/28/2000 & 8.42 & 740 \\
\hline 17:50_07/26/2001 & 2.38 & 9.7 \\
\hline 17:10_08/05/2001 & 2.68 & 16 \\
\hline 14:50_08/09/2001 & 2.80 & 19 \\
\hline 21:00_08/13/2001 & 2.07 & 5.1 \\
\hline 20:20_07/25/2002 & 2.26 & 7.7 \\
\hline Unknown_08/13/2002 & 2.50 & 12 \\
\hline 16:25_04/17/2005 & 2.31 & 8.5 \\
\hline
\end{tabular}


E256 Cañon de Valle below MDA-P

Period Starting: $\quad$ 00:00_01/24/2002

Period Ending: $\quad$ 24:00_09/30/2006

Peak Discharge above base of $10 \mathrm{cfs}$

\begin{tabular}{|c|c|c|}
\hline Time & Gage Height & Discharge \\
\hline 23:20_06/21/2002 & 1.79 & 18 \\
\hline 17:10_08/20/2004 & 1.41 & 13 \\
\hline 15:50_07/15/2005 & 1.34 & 13 \\
\hline 13:45_08/24/2005 & 1.74 & 19 \\
\hline 13:15_08/08/2006 & 1.19 & 10 \\
\hline 12:15_08/25/2006 & 1.28 & 12 \\
\hline 12:50_09/11/2006 & 1.44 & 14 \\
\hline
\end{tabular}

E262 Cañon de Valle above Water

Period Starting: $\quad$ 00:00_10/01/1998

Period Ending: 24:00_09/30/2006

Peak Discharge above base of $5.0 \mathrm{cfs}$

\begin{tabular}{|l|c|c|}
\hline Time & Gage Height & Discharge \\
\hline 17:00_08/09/2001 & 3.59 & 26 \\
\hline $00: 10 \_06 / 22 / 2002$ & 3.65 & 32 \\
\hline 14:20_08/23/2003 & 3.52 & 26 \\
\hline 14:00_07/23/2004 & 3.95 & 52 \\
\hline 14:55_08/11/2004 & 3.63 & 31 \\
\hline 16:55_08/20/2004 & 4.10 & 63 \\
\hline 15:10_08/24/2005 & 3.00 & 9.3 \\
\hline 13:05_08/25/2006 & 4.05 & 59 \\
\hline
\end{tabular}




\section{E2625 Water below MDA AB}

Period Starting: $\quad$ 00:00_05/07/2001

Period Ending: $\quad$ 24:00_09/30/2006

Peak Discharges above base of $10 \mathrm{cfs}$

\begin{tabular}{|c|c|c|}
\hline Time & Gage Height & Discharge \\
\hline $00: 10 \_06 / 22 / 2002$ & 3.65 & 53 \\
\hline 14:35_07/14/2002 & 2.50 & 11 \\
\hline $06: 50 \_09 / 10 / 2002$ & 2.66 & 14 \\
\hline 13:20_08/23/2003 & 2.51 & 11 \\
\hline 14:00_07/23/2004 & 2.96 & 22 \\
\hline 17:45_08/20/2004 & 4.30 & 195 \\
\hline 17:25_06/29/2006 & 3.62 & 65 \\
\hline 13:30_08/25/2006 & 4.30 & 195 \\
\hline
\end{tabular}

\section{E263 Water at SR 4}

Period Starting: $\quad$ 00:00_10/01/1998

Period Ending: 24:00_10/01/2006

Peak Discharge above base of $35 \mathrm{cfs}$

\begin{tabular}{|c|c|c|}
\hline Time & Gage Height & Discharge \\
\hline 13:50_06/28/2000 & 3.78 & 306 \\
\hline 23:25_08/29/2000 & 1.64 & 54 \\
\hline $02: 45 \_10 / 28 / 2000$ & 2.08 & 87 \\
\hline 13:40_08/03/2001 & 1.92 & 72 \\
\hline $00: 55 \_06 / 22 / 2002$ & 2.68 & 149 \\
\hline $08: 00 \_09 / 10 / 2002$ & 1.50 & 40 \\
\hline 18:30_08/20/2004 & 2.66 & 147 \\
\hline 14:20_08/25/2006 & 1.84 & 66 \\
\hline
\end{tabular}




\section{E265 Water below SR 4}

Period Starting: $\quad$ 00:00_10/01/1993

Period Ending: 24:00_09/30/2006

Peak Discharge above base of $50 \mathrm{cfs}$

\begin{tabular}{|l|c|c|}
\hline \multicolumn{1}{|c|}{ Time } & Gage Height & Discharge \\
\hline 14:00_06/28/2000 & 5.13 & 274 \\
\hline 19:00_08/19/2000 & 1.43 & 53 \\
\hline 02:50_10/28/2000 & 1.88 & 82 \\
\hline 13:45_08/03/2001 & 2.03 & 92 \\
\hline Unknown_06/22/2002 & 2.34 & 105 \\
\hline 18:30_08/20/2004 & 2.3 & 100 \\
\hline
\end{tabular}

E267 Potrillo above SR 4

Period Starting: 00:00_10/06/1999

Period Ending: 24:00_09/30/2006

Peak Discharge above base of $5 \mathrm{cfs}$

\begin{tabular}{|c|c|c|}
\hline Time & Gage Height & Discharge \\
\hline 20:55_08/09/2000 & 1.35 & 7.0 \\
\hline 20:56_10/23/2000 & 1.26 & 6.8 \\
\hline 14:05_08/28/2002 & 1.72 & 15 \\
\hline 16:50_05/26/2003 & 1.95 & 20 \\
\hline 13:40_08/19/2003 & 0.98 & 14 \\
\hline 00:00_08/26/2003 & 0.53 & 5.8 \\
\hline 19:10_09/09/2003 & 0.81 & 11 \\
\hline 15:15_09/28/2005 & 1.62 & 12 \\
\hline 14:40_08/01/2006 & 1.39 & 7.6 \\
\hline
\end{tabular}




\section{E275 Ancho below SR 4}

Period Starting: $\quad$ 00:00_10/06/1994

Period Ending: 24:00_09/30/2006

Peak Discharge above base of $15 \mathrm{cfs}$

\begin{tabular}{|l|c|c|}
\hline \multicolumn{1}{|c|}{ Time } & Gage Height & Discharge \\
\hline 19:25_07/29/2000 & 1.52 & 17 \\
\hline 16:30_08/06/2000 & 2.35 & 349 \\
\hline 20:50_08/09/2000 & 1.57 & 25 \\
\hline 17:20_08/18/2000 & 1.55 & 21 \\
\hline 21:20_10/23/2000 & 1.62 & 34 \\
\hline 17:20_05/26/2003 & 2.74 & 534 \\
\hline 14:30_08/19/2003 & 2.04 & 201 \\
\hline 14:00_08/10/2004 & 1.97 & 168 \\
\hline 11:40_10/05/2004 & 1.64 & 38 \\
\hline $00: 45 \_07 / 05 / 2006$ & 1.71 & 57 \\
\hline 20:15_08/13/2006 & 1.55 & 21 \\
\hline 15:25_08/19/2006 & 2.30 & 325 \\
\hline
\end{tabular}

\section{E350 Rio de los Frijoles at Bandalier}

Period Starting: $\quad$ 00:00_10/01/2000

Period Ending: 24:00_09/30/2006

Peak Discharge above base of $20 \mathrm{cfs}$

\begin{tabular}{|l|c|c|}
\hline \multicolumn{1}{|c|}{ Time } & Gage Height & Discharge \\
\hline 17:05_05/26/2003 & 2.43 & 21 \\
\hline 17:35_09/26/2004 & 2.53 & 42 \\
\hline 08:30_02/12/2005 & 2.7 & 44 \\
\hline 21:15_04/17/2005 & 2.43 & 21 \\
\hline 19:15_06/29/2006 & 3.21 & 90 \\
\hline 00:30_07/05/2006 & 2.89 & 62 \\
\hline 19:45_08/13/2006 & 3.21 & 90 \\
\hline 15:45_08/19/2006 & 2.66 & 40 \\
\hline
\end{tabular}




\section{Gaging Stations Omitted from this Publication}

For existing stations, omitted from this publication, information was extracted from existing raw and/or partially reduced data files using the following procedure.

All field collected electronic data is transferred into a commercial program referred to as "HYDSTRA". This data was accessed via "Hydstra Data Manager's Workbench." "Raw Level" and, where available, discharge files were evaluated for relative change to the recorded stage. If visually obvious then it was considered to be a day where some streamflow was recorded. The highest relative change was assumed to be the peak for the water year. Documented missing data or gaps in Station's electronic record were tallied to estimate the days without available data. A number of these Stations have been recently upgraded with equipment that should reduce the gaps in station data and provide a better record for future publication.

All flow related information in this table should be considered estimated and/or provisional (draft).

\begin{tabular}{|l|l|l|l|l|}
\hline Station & & $\begin{array}{l}\text { Estimated } \\
\text { date of } \\
\text { peak flow }\end{array}$ & $\begin{array}{l}\text { Gap in } \\
\text { record } \\
\text { (days) }\end{array}$ & Comments \\
\hline E025 (LA Canyon at LA) & 89 & $08 / 08$ & 0 & Back-up for E026 for flows <16 cfs \\
\hline E026.85 (LASMA 5.5) & 4 & $08 / 08$ & $\sim 2$ & $\begin{array}{l}\text { New station, Installed 03/08/2006. } \\
\text { Rating curve in development, will } \\
\text { publish in Water Year (WY) 2007 }\end{array}$ \\
\hline $\begin{array}{l}\text { E039 (DP Canyon below } \\
\text { Meadows) }\end{array}$ & 47 & $08 / 25$ & $<1$ & $\begin{array}{l}\text { Equipment Failures. Will publish in } \\
\text { WY 2007 }\end{array}$ \\
\hline E049 (LA Weir) & 22 (level & $08 / 08$ & 0 & $\begin{array}{l}\text { Raw Stage, (i.e. water level behind } \\
\text { low head weir) }\end{array}$ \\
\hline E056 (Acid Canyon at Mouth) & 15 & $08 / 08$ & 0 & Rating curve in development \\
\hline $\begin{array}{l}\text { E089 (Guaje Canyon above Mouth } \\
\text { of Rendija Canyon) }\end{array}$ & 7 & $08 / 26$ & $<1$ & $\begin{array}{l}\text { Will publish in WY 2007 to include } \\
\text { previous water years 2005 and 2006 }\end{array}$ \\
\hline E090 (Rendija Canyon at Mouth) & 4 & $08 / 08$ & 22 & No rating curve \\
\hline $\begin{array}{l}\text { E099 (Guaje Canyon below } \\
\text { SR 502) }\end{array}$ & 3 & $08 / 08$ & 43 & No rating curve \\
\hline $\begin{array}{l}\text { E110 (Los Alamos Canyon near } \\
\text { Otowi Bridge) }\end{array}$ & 13 & $08 / 08$ & 0 & $\begin{array}{l}\text { Will publish WY 2007 to include } \\
\text { previous water years 2003 - 2006 }\end{array}$ \\
\hline $\begin{array}{l}\text { E122 (Sandia Canyon near Roads } \\
\text { and Grounds at TA-3) }\end{array}$ & 20 & unknown & 97 & $\begin{array}{l}\text { Rating curve in development will } \\
\text { publish in WY 2007 }\end{array}$ \\
\hline $\begin{array}{l}\text { E122.2 (Sandia Canyon Tributary } \\
\text { from Roads and Grounds) }\end{array}$ & 24 & $08 / 08$ & $\sim 10.5$ & $\begin{array}{l}\text { Equipment upgrade, record projected } \\
\text { to begin 07/01/2007. }\end{array}$ \\
\hline $\begin{array}{l}\text { E122.3 (Sandia Canyon Tributary } \\
\text { from Sigma Building) }\end{array}$ & $15(?)$ & $08 / 25$ & $\sim 15$ & $\begin{array}{l}\text { Equipment upgrade, record projected } \\
\text { to begin 07/01/2007. }\end{array}$ \\
\hline $\begin{array}{l}\text { E122.35 (Sandia Canyon Tributary } \\
\text { from Sigma Building) }\end{array}$ & 18 & $08 / 25$ & $\sim 1$ & $\begin{array}{l}\text { Equipment upgrade, record projected } \\
\text { to begin 07/01/2007. }\end{array}$ \\
\hline $\begin{array}{l}\text { E124 (Sandia Canyon Truck } \\
\text { Route) }\end{array}$ & 5 & $08 / 25$ & 174 & $\begin{array}{l}\text { Station damaged 08/25/2006, } \\
\text { relocated downstream 03/23/2007. } \\
\text { No rating curve }\end{array}$ \\
\hline
\end{tabular}




\begin{tabular}{|c|c|c|c|c|}
\hline Station & & $\begin{array}{l}\text { Estimated } \\
\text { date of } \\
\text { peak flow }\end{array}$ & $\begin{array}{l}\text { Gap in } \\
\text { record } \\
\text { (days) }\end{array}$ & Comments \\
\hline E201.1 (TA-50-006(c)) & 8 & $08 / 25$ & $\sim 211$ & $\begin{array}{l}\text { Equipment upgrade, record projected } \\
\text { to begin } 07 / 01 / 2007 \text {. }\end{array}$ \\
\hline E201.3 (TA-50 Area C) & 25 & $07 / 03$ & $\sim 8$ & $\begin{array}{l}\text { Equipment upgrade record projected } \\
\text { to begin } 07 / 01 / 2007 \text {. }\end{array}$ \\
\hline E220 (TA-54 RANT) & 12 & $07 / 05$ & $\sim 24$ & $\begin{array}{l}\text { Equipment upgrade projected to } \\
\text { begin } 05 / 01 / 2007 \text {. }\end{array}$ \\
\hline E220.5 (Area J West) & 1 & $04 / 14$ & $\sim 9$ & Gage discontinued \\
\hline E220.7 (Area J East) & 3 & $07 / 01$ & $\sim 4$ & Gage discontinued \\
\hline E223 (Area L) & 3 & $07 / 05$ & $\sim 21$ & $\begin{array}{l}\text { Equipment upgraded, record } \\
\text { projected to begin } 03 / 14 / 2007\end{array}$ \\
\hline E227 (G-6) & 8 & $08 / 06$ & $\sim 28$ & $\begin{array}{l}\text { Equipment upgraded, record } \\
\text { projected to begin } 04 / 19 / 2007\end{array}$ \\
\hline E245.5 Pajarito above Three Mile) & 5 & $08 / 25$ & 0 & Rating curve in development \\
\hline E247 (G-1) & 2 & $07 / 05$ & $\sim 7$ & $\begin{array}{l}\text { Equipment upgraded, record } \\
\text { projected to begin } 03 / 14 / 2007\end{array}$ \\
\hline E248 (G-2) & 7 & $08 / 06$ & 0 & $\begin{array}{l}\text { Equipment upgraded, record } \\
\text { projected to begin } 02 / 08 / 2006\end{array}$ \\
\hline $\mathrm{E} 248.5(\mathrm{G}-3)$ & 9 & 08/06 & $\sim 4$ & $\begin{array}{l}\text { Equipment upgraded, record } \\
\text { projected to begin } 03 / 07 / 2006\end{array}$ \\
\hline E249 (G-5) & 3 & $07 / 05$ & $\sim 17$ & $\begin{array}{l}\text { Equipment upgraded, record } \\
\text { projected to begin } 02 / 16 / 2007\end{array}$ \\
\hline $\begin{array}{l}\text { E252.5 (Water above S-Site } \\
\text { Canyon) }\end{array}$ & $>4$ & $08 / 25$ & $\sim 62$ & Rating curve in development \\
\hline E256.5 (TA-14 Q-Site) & N/A & N/A & $\mathrm{N} / \mathrm{A}$ & $\begin{array}{l}\text { New station 09/26/2006, rating curve } \\
\text { in development. Publish WY } 2007\end{array}$ \\
\hline $\begin{array}{l}\text { E257 (Canyon de Valle Tributary } \\
\text { at S-Site) }\end{array}$ & 10 & 07/01 & $\sim 14$ & $\begin{array}{l}\text { Equipment upgraded, record } \\
\text { projected to begin on } 04 / 26 / 2007\end{array}$ \\
\hline $\begin{array}{l}\text { E262.3 (Water Canyon Tributary } \\
\text { from DAHRT Facility) }\end{array}$ & & & & Gage discontinued \\
\hline $\begin{array}{l}\text { E266 (Portrillo Canyon above } \\
\text { Discharge Sink) }\end{array}$ & 2 & $04 / 05$ & & $\begin{array}{l}\text { Limited record. Rating curve in } \\
\text { development. }\end{array}$ \\
\hline E267.4 (TA-36 Minie Site) & & & 259 & Limited record \\
\hline $\begin{array}{l}\text { E274 (North Fork Ancho Canyon } \\
\text { at TA-59) }\end{array}$ & 4 & $08 / 04$ & 64 & Rating curve in development \\
\hline $\begin{array}{l}\text { E338 (Chaquehui Canyon } \\
\text { South Site) }\end{array}$ & $>2$ & unknown & $\sim 200$ & Rating curve in development \\
\hline $\begin{array}{l}\text { E340 (Chaquehui Canyon } \\
\text { Main Site) }\end{array}$ & 5 & $08 / 19$ & 0 & Rating curve in development \\
\hline
\end{tabular}


Appendix A 

Monthy Precipitation (inches)

Los Alamos National Laboratory Meteorological Stations;

Water Year 2006 (October 2005 - September 2006)

Data Source, LANL Weather Machine - for further documentation and information, http://weather.lanl.gov

\begin{tabular}{|l|c|c|c|c|c|c|}
\hline Month & TA-6 & TA-49 & TA-53 & TA-54 & NCOM & PJMT \\
\hline October & 1.11 & 1.57 & 1.05 & 1.59 & 0.64 & 1.67 \\
\hline November & 0.07 & 0.10 & 0.11 & 0.08 & 0.08 & 0.05 \\
\hline December & 0.01 & 0 & 0.01 & 0 & 0.03 & 0.07 \\
\hline January & 0.15 & 0.08 & 0.14 & 0.08 & 0.18 & 0.25 \\
\hline February & 0.02 & 0 & 0 & 0 & 0.02 & 0.05 \\
\hline March & 0.63 & 0.42 & 0.33 & 0.33 & 0.81 & 1.07 \\
\hline April & 0.51 & 0.33 & 0.40 & 0.25 & 0.50 & 0.62 \\
\hline May & 0.22 & 0.20 & 0.17 & 0.18 & 0.27 & 0.32 \\
\hline June & 1.76 & 0.82 & 0.79 & 0.94 & 1.19 & 1.09 \\
\hline July & 2.26 & 1.94 & 3.58 & 2.17 & 3.16 & 3.95 \\
\hline August & 5.85 & 3.83 & $>3.82 *$ & 4.58 & 7.25 & 6.9 \\
\hline September & 1.36 & 1.09 & 0.90 & 0.60 & 1.04 & 1.64 \\
\hline Total & $\mathbf{1 3 . 9 5}$ & $\mathbf{1 0 . 3 8}$, & $>\mathbf{1 1 . 3}$ & $\mathbf{1 0 . 8}$ & $\mathbf{1 5 . 1 7}$ & $\mathbf{1 7 . 6 8}$ \\
\hline
\end{tabular}

*incomplete data - days missing

$\mathrm{NCOM}=$ North Community

PJMT $=$ Pajarito Mountain 

This report has been reproduced directly from the best available copy. It is available electronically on the Web (http://www.doe.gov/bridge).

Copies are available for sale to U.S. Department of Energy employees and contractors from:

Office of Scientific and Technical Information

P.O. Box 62

Oak Ridge, TN 37831

(865) 576-8401

Copies are available for sale to the public from: National Technical Information Service

U.S. Department of Commerce

5285 Port Royal Road

Springfield, VA 22161

(800) 553-6847 
- Los Alamos NATIONAL LABORATORY 